\title{
Perceptions of the Curriculum for Agricultural Science Education (CASE) as Perceived by Agricultural Educators.
}

Lauren Irene Devine

Follow this and additional works at: https://researchrepository.wvu.edu/etd

\section{Recommended Citation}

Devine, Lauren Irene, "Perceptions of the Curriculum for Agricultural Science Education (CASE) as Perceived by Agricultural Educators." (2016). Graduate Theses, Dissertations, and Problem Reports. 8174. https://researchrepository.wvu.edu/etd/8174

This Thesis is protected by copyright and/or related rights. It has been brought to you by the The Research Repository @ WVU with permission from the rights-holder(s). You are free to use this Thesis in any way that is permitted by the copyright and related rights legislation that applies to your use. For other uses you must obtain permission from the rights-holder(s) directly, unless additional rights are indicated by a Creative Commons license in the record and/ or on the work itself. This Thesis has been accepted for inclusion in WVU Graduate Theses, Dissertations, and Problem Reports collection by an authorized administrator of The Research Repository @ WVU. For more information, please contact researchrepository@mail.wvu.edu. 
Perceptions of the Curriculum for Agricultural Science Education (CASE) as Perceived by Agricultural Educators

\author{
Lauren Irene Devine
}

\author{
Thesis submitted to the \\ Davis College of Agriculture, Natural Resources and Design \\ at West Virginia University \\ in partial fulfillment of the requirements \\ for the degree of \\ Master of Science \\ in \\ Agricultural and Extension Education \\ Stacy A. Gartin, Ph.D., Chair \\ Harry N. Boone Jr., Ph. D. \\ Jessica M. Blythe, Ph.D.
}

School of Design and Community Development

\author{
Morgantown, West Virginia \\ 2016
}

Keywords: Agricultural Education, Agriculture, Education, CASE

Copyright 2016 Lauren Irene Devine 


\begin{abstract}
Perceptions of the Curriculum for Agricultural Science Education (CASE) as Perceived by Agricultural Educators
\end{abstract}

\title{
Lauren Devine
}

The purpose of this study was to determine the perceptions of educators using the CASE curriculum related to the lesson plans, materials and overall courses in the curriculum. The research was also aimed to determine the perceptions of educators on the CASE curriculum as it relates to the total agricultural education model and the attitudes of students' views of the CASE curriculum as perceived by their teachers. The population for this study was 1,021 agricultural educators across the United States who have been trained in CASE and are currently teaching in a high school classroom. The researcher conducted a descriptive survey. The training for the courses was well received by the respondents as well as the course materials and courses in general. Respondents identified problems in different courses with the incorporation of FFA and SAEs. The largest problem respondents identified was the level of student's positive excitement throughout the year. 


\section{ACKNOWLEDGEMENTS}

I would like to thank my committee, Dr. Gartin, Dr. Blythe and Dr. Boone. Dr. Gartin, you have been a long time mentor and friend. Thank you for the tough love, constant support and endless edits. You have helped me grow as writer and teacher throughout my time in graduate school. Dr. Blythe, thank you for all the help with Qualtrics and many edits and questions. Thank you for joining me in my Starbucks habit. You have helped me grow as a researcher this semester and a writer too. Dr. Boone, thank you for always answering my endless questions and all the help with statistics. I appreciate having each of you on my committee and your help throughout this process.

I would like to thank my family for their constant support and love. You have all helped me in ways throughout this journey with words of encouragement, letting me get away from school and giving advice. I love you all and I couldn't have done it without each of you. To my graduate school friends that have become like family, I thank you for your unwavering support, constant thesis talk and the constant reminder that we should be writing. Dawn Mackenzie and Aisury Vasquez, my friends who turned in family. I could not have done this without you and your strong friendship. Thank you for always being there for me.

Lastly to my loving husband and biggest support system, Tom Devine, thank you. Thank you for always being there to answer questions read my thesis and cheer me up. Your patience and support have been a constant reminder that I would get through this. I

cannot thank you enough for the love, encouragement and ice cream through this process. Your love means the world to me, and I thank you for always showing me the positives in situations and loving me no matter what. I am so lucky to have you in my life, I love you. 


\section{TABLE OF CONTENTS}

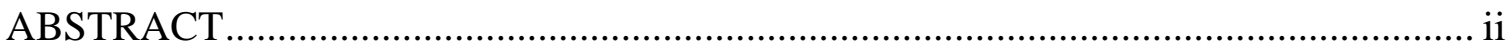

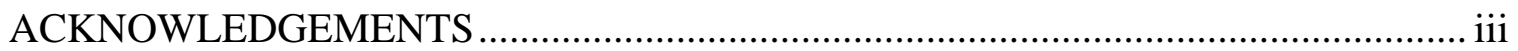

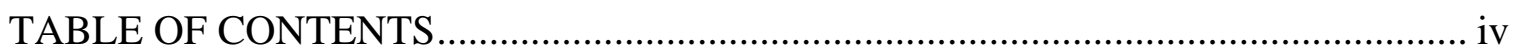

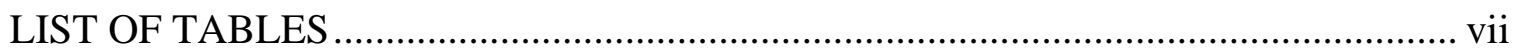

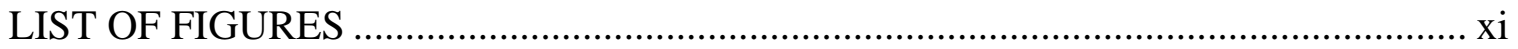

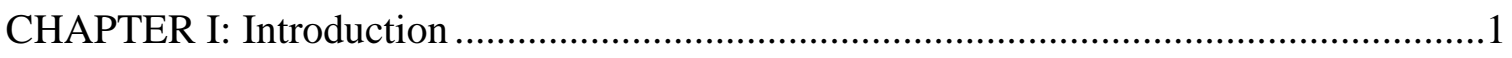

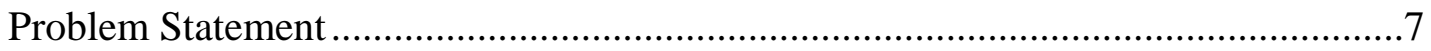

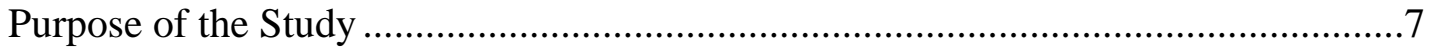

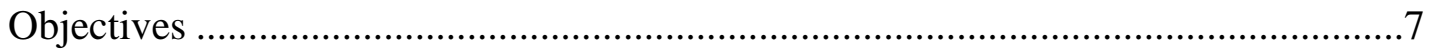

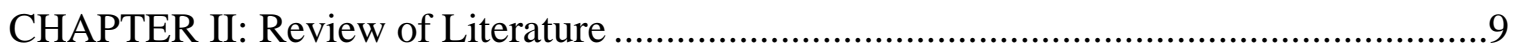

Curriculum Development and Evaluation ...............................................................

Agricultural Education Curriculum ....................................................................13

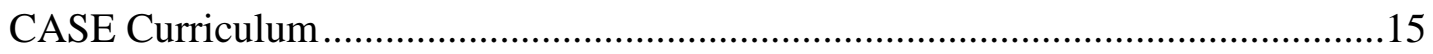

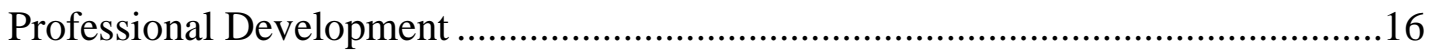

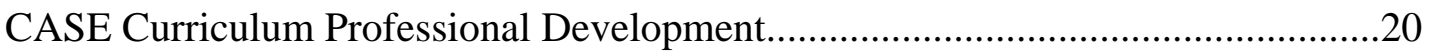

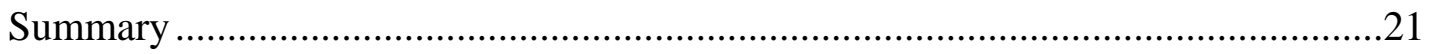

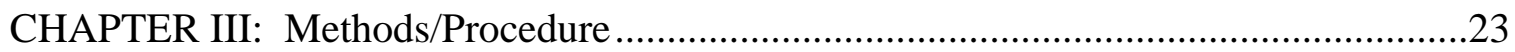

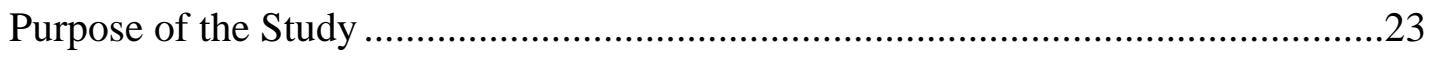

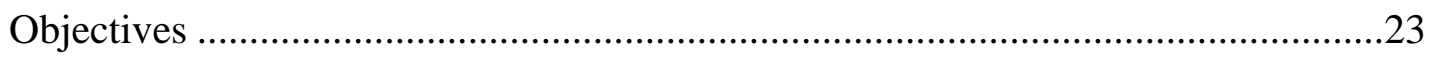

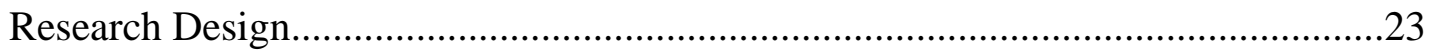

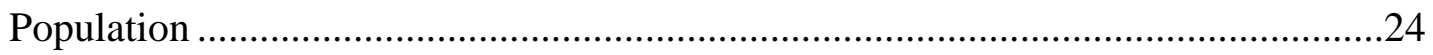

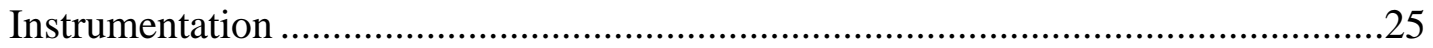

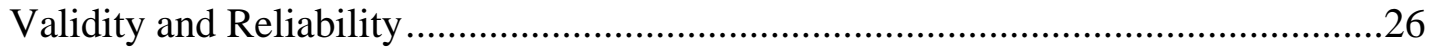

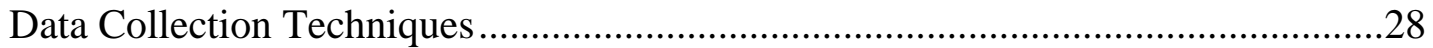




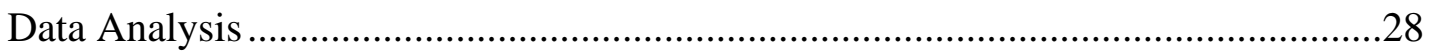

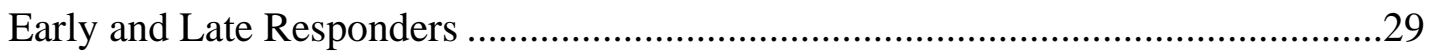

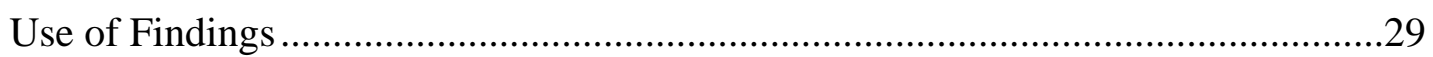

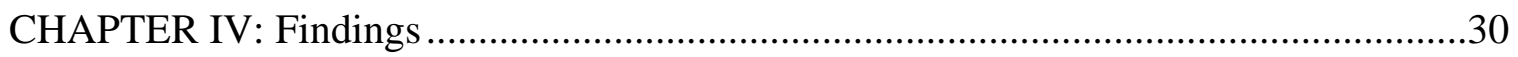

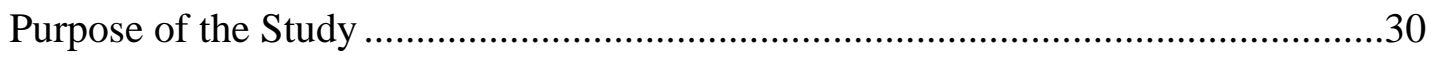

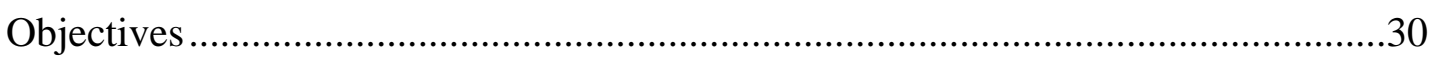

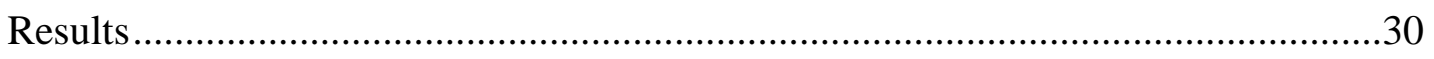

Introduction to Agriculture, Food and Natural Resources (AFNR) .......................45

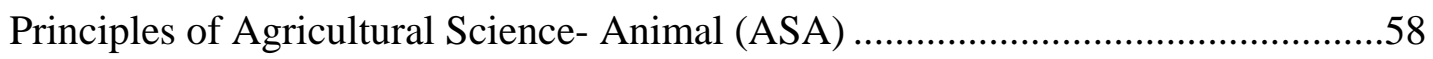

Principles of Agricultural Science- Plant (ASP) .................................................. 71

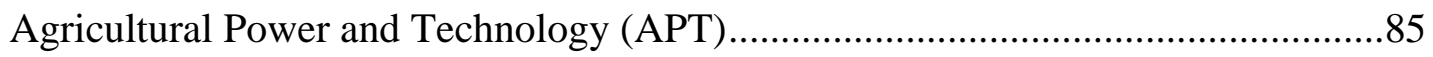

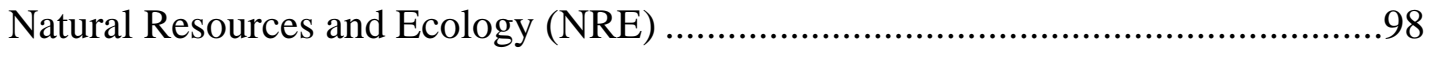

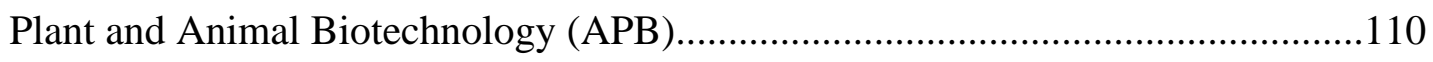

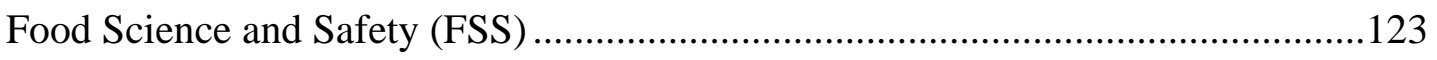

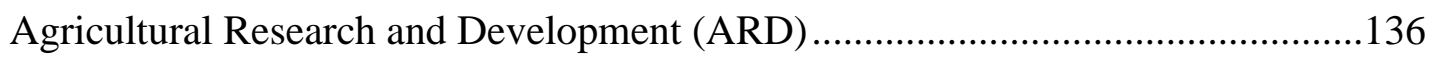

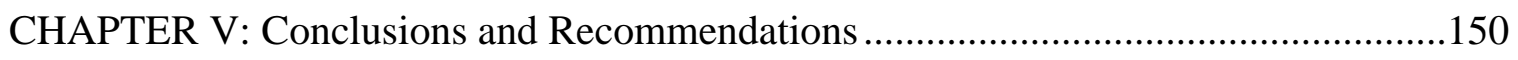

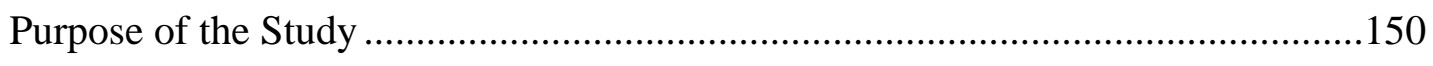

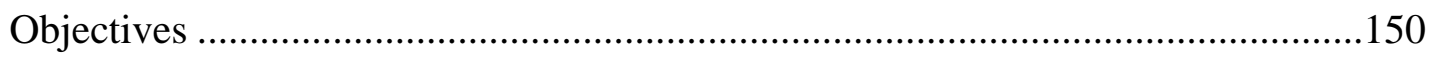

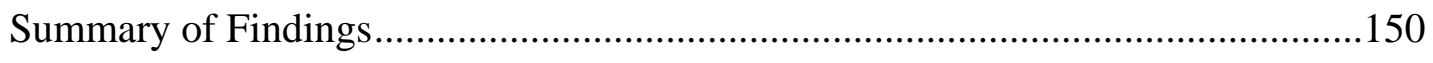

Introduction to Agriculture, Food and Natural Resources (AFNR)......................151

Principles of Agricultural Science- Animal (ASA)...........................................152

Principles of Agricultural Science- Plant (ASP).............................................. 154

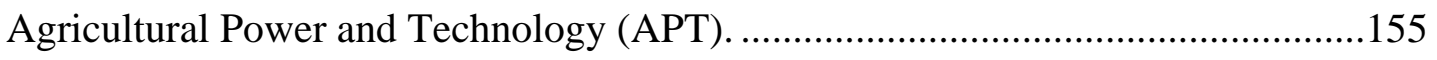

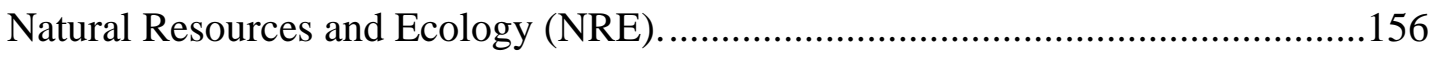

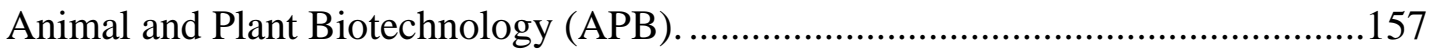


Food Science and Safety (FSS).

Agricultural Research and Development (ARD), ....................................................160

Conclusions and Implications ………………………........................................162

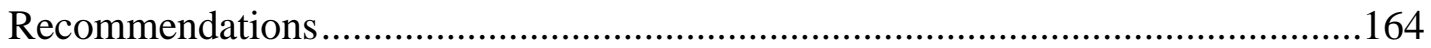

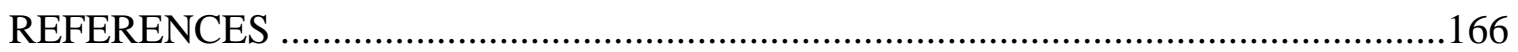

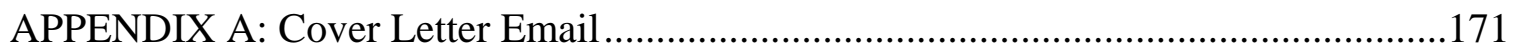

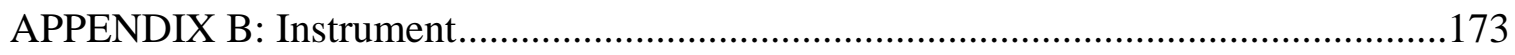

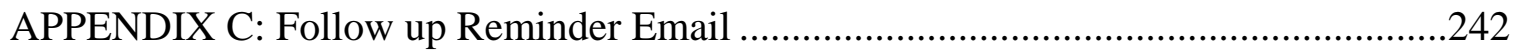

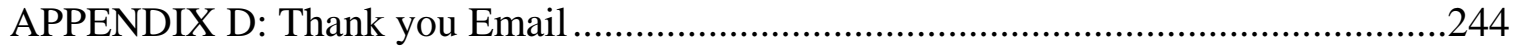

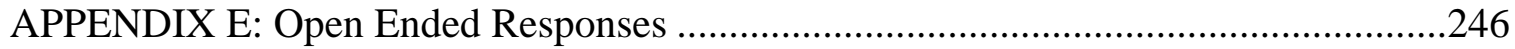

VITAE 


\section{LIST OF TABLES}

Table Title

Page

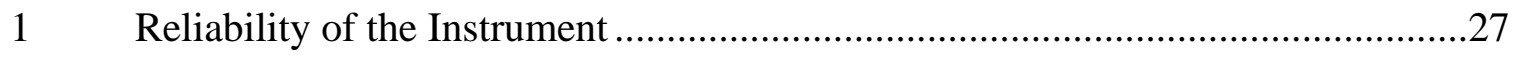

2 Demographic Information: Gender, Race and Level of Education ......................32

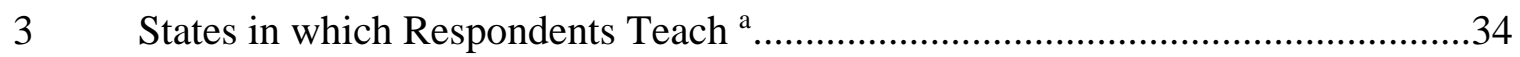

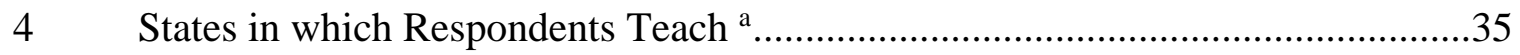

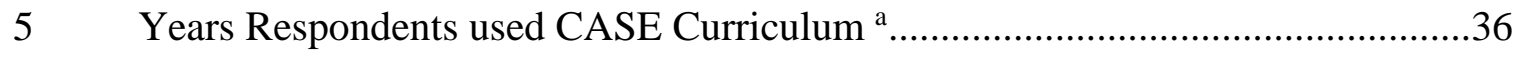

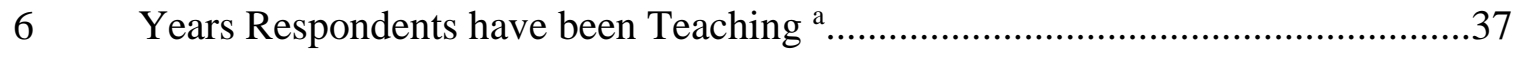

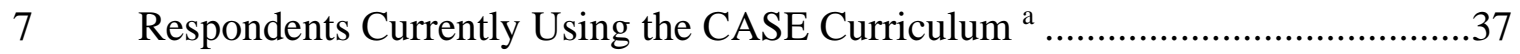

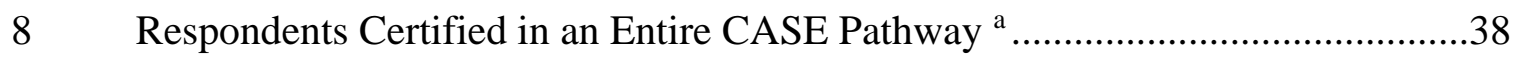

$9 \quad$ Years Respondents Trained in CASE Course .................................................42

10 Are you Currently Teaching a CASE Course in your Classroom?.......................44

11 CASE Courses Respondents were Currently Trained ${ }^{\mathrm{a}}$.....................................46

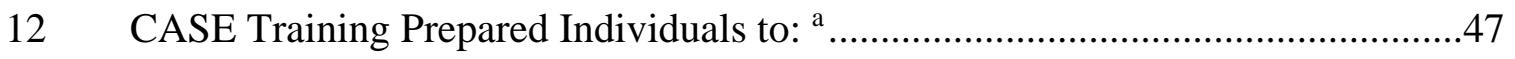

13 Respondents Who Required Assistance from CASE When Implementing

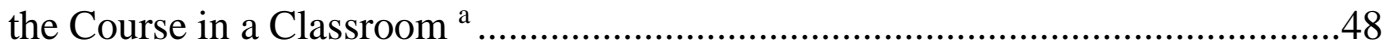

14 Aspects of Post CASE Training Assistance ${ }^{\mathrm{a}}$................................................49

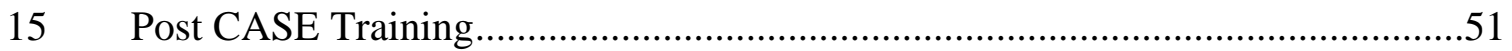

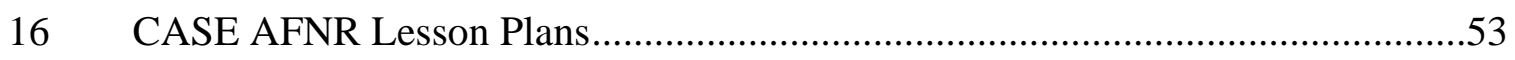

17 CASE Incorporation of Parts of the Agricultural Education Model .....................55

18 Student Perceptions of CASE Creativity as Perceived by Their Teachers ............57

19 Students' Levels of Positive Excitement Over Time ......................................58

20 The CASE Training Prepared Individuals to: ...............................................60 
21 Respondents Who Required Assistance from CASE When Implementing the Course in a Classroom ${ }^{\mathrm{a}}$

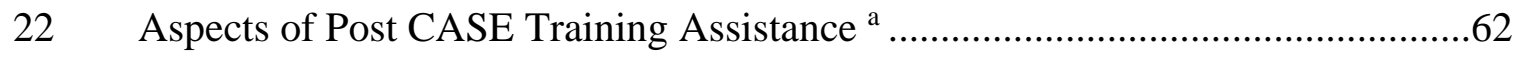

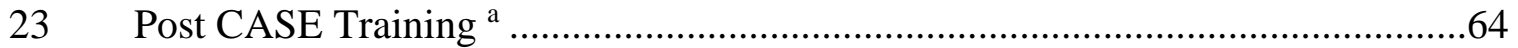

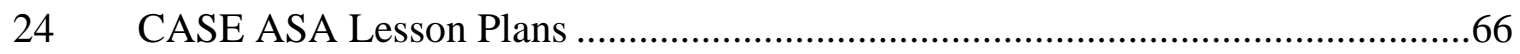

25 CASE Incorporation of Parts of the Agricultural Education Model .....................68

26 Student Perceptions of CASE Creativity as Perceived by Their Teachers............70

27 Students' Levels of Positive Excitement ....................................................... 71

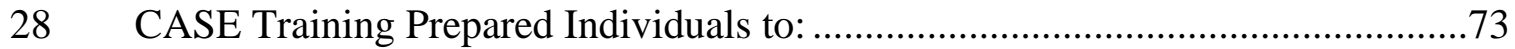

29 Respondents Who Required Assistance from CASE When Implementing

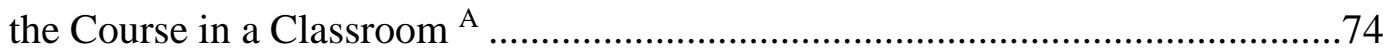

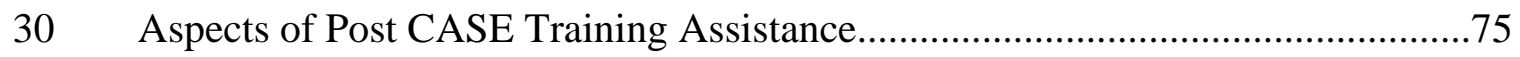

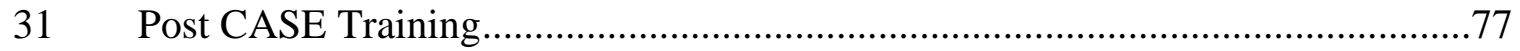

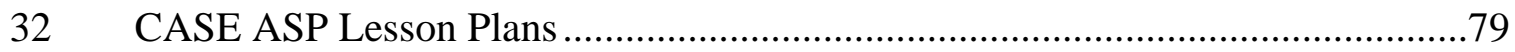

33 CASE Incorporation of Parts of the Agricultural Education Model.....................81

34 Student Perceptions of Case Creativity as Perceived by Their Teachers .............83

35 Students' Levels of Positive Excitement Over Time .........................................84

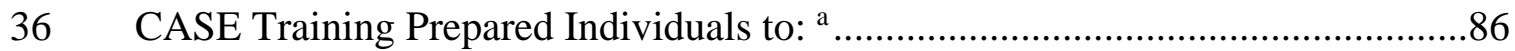

37 Respondents Who Required Assistance from CASE When Implementing

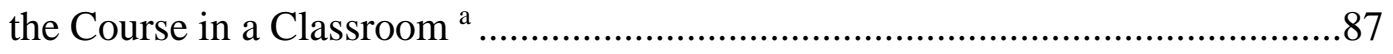

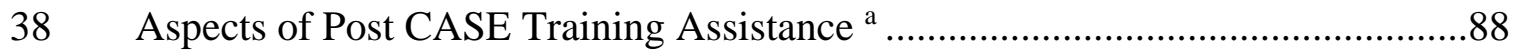

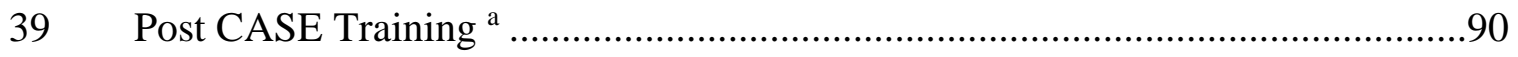

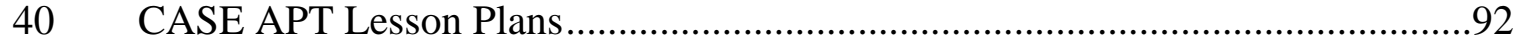


41 CASE Incorporation of Parts of the Agricultural Education Model ${ }^{\text {a }}$

42 Student Perceptions of CASE Creativity as Perceived by Their Teachers ${ }^{\text {a }}$...........96

43 Students' Levels of Positive Excitement Over Time ......................................97

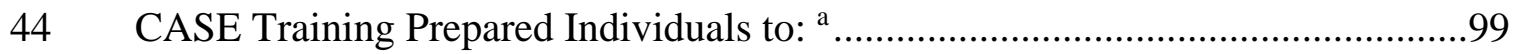

45 Respondents Who Required Assistance from CASE When Implementing

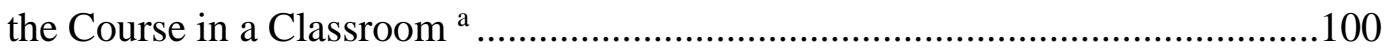

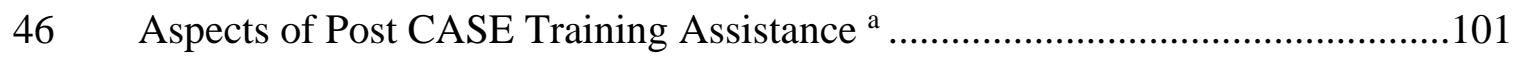

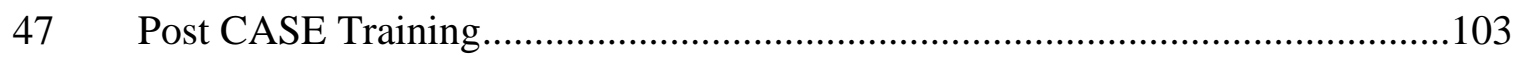

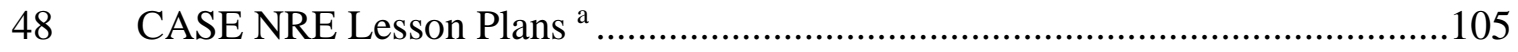

49 CASE Incorporation of Parts of the Agricultural Education Model...................107

50 Student Perception of CASE Creativity as Perceived by Their Teachers ${ }^{\text {a }}$.........109

51 Students' Levels of Positive Excitement Over Time ......................................110

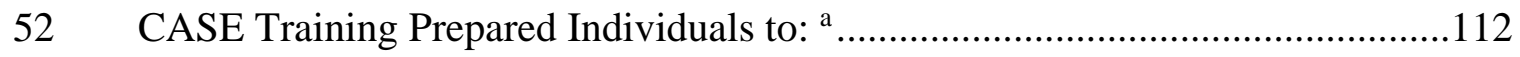

53 Respondents Who Required Assistance from CASE When Implementing the Course in a Classroom ${ }^{\mathrm{a}}$..................................................................... 113

$54 \quad$ Aspects of Post CASE Training Assistance ${ }^{\mathrm{a}}$............................................114

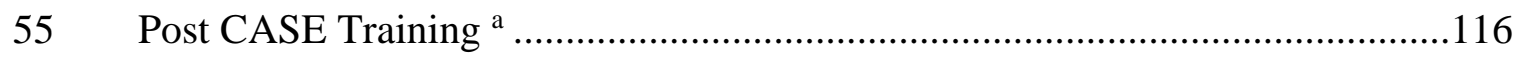

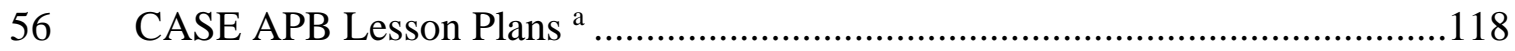

57 CASE Incorporation of Parts of the Agricultural Education Model...................120

58 Student Perceptions of CASE Creativity as Perceived by Their Teachers..........122

59 Students' Levels of Positive Excitement Over Time ......................................123

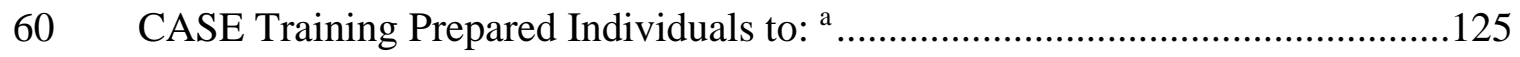


61 Respondents Who Required Assistance from CASE When Implementing

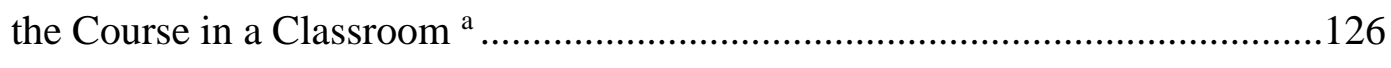

$62 \quad$ Aspects of Post CASE Training Assistance.................................................127

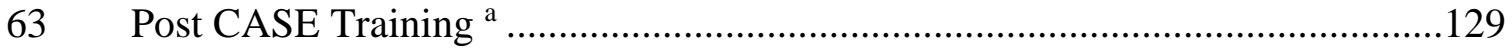

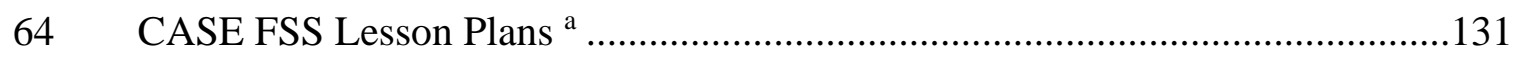

65 CASE Incorporation of Parts of the Agricultural Education Model a .................133

66 Student Perceptions of CASE Creativity as Perceived by Their Teachers ${ }^{\mathrm{a}}$.........135

67 Students' Levels of Positive Excitement Over Time .......................................136

68 CASE Training Prepared Individuals to: ..................................................138

69 Respondents Who Required Assistance from CASE When Implementing

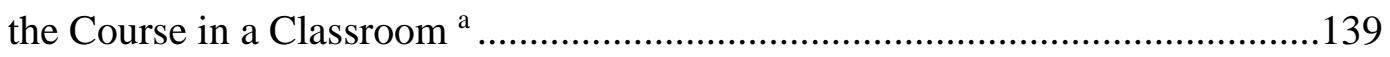

$70 \quad$ Aspects of Post CASE Training Assistance ${ }^{\mathrm{a}}$............................................. 140

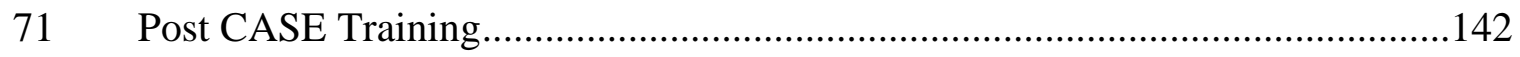

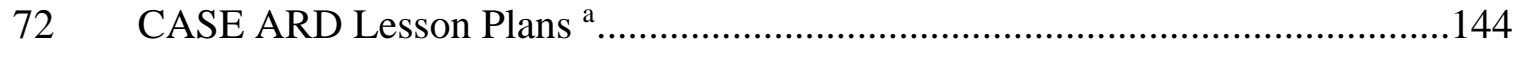

73 CASE Incorporation of Parts of the Agricultural Education Model...................146

74 Student Perception of CASE Creativity as Perceived by Their Teachers ${ }^{\text {a }}$..........148

75 Students' Levels of Positive Excitement Over Time .....................................149 


\section{LIST OF FIGURES}

Figure 1: The CASE Model from Understanding the CASE Model (CASE, 2012)...........5

Figure 2: Core Features of CASE and Professional Development Model adapted from proposed core conceptual framework for studying the effects of professional development on teachers and students (Desimone, 2009)...........6 


\section{CHAPTER I}

\section{Introduction}

Education is the backbone of America. Agricultural education has been evolving since its inception. The foundation of agricultural education is the three circle model. The model includes classroom and laboratory instruction, FFA, and Supervised Agriculture Experience Program (SAE) (National FFA Organization, 2013). Of these three aspects, the most emphasis is given to classroom and laboratory instruction. Classroom and laboratory instruction promotes student engagement in lessons through hands-on learning. Students' learning in agricultural education evolves as new aspects of agriculture emerge (National FFA Organization, 2013). Agriculture continues to grow and change with the growth of technology. Technology allows students to have more hands- on experiences by connecting technology to agriculture. The advances in technology are rapid and it is crucial that agriculture meet these changes.

Boone, H., Gartin, Boone D., \& Hughes (2006) found in the 70s and 80s that agricultural education did not correspond with the biotechnical advances of that time. They concluded that the curriculum needed to change to keep pace with the everchanging science. Enrollment in agricultural education suffered because it was a vocational subject, which college recruiters did not want to see (Thompson \& Balschweid, 2000). The goal of agricultural education is to "teach students a variety of skills, including science, math, communications, leadership, management and technology" (NAAE, 2015, What is Agricultural Education?). SAE and FFA are integral parts of the program and aim to "provide opportunities for leadership development, personal growth and career success." (National FFA Organization, 2015, Supervised 
Agricultural Experiences). The program as it stood in the 70s and 80s did not meet these standards and had to evolve to incorporate more science aspects to better prepare students for secondary schools and future careers (Boone, H. et. al, 2006). To address these concerns, the agricultural education program incorporated biotechnology (Boone, H. et. al, 2006). Biotechnology had many of the science and math aspects the curriculum needed. Agriscience also served as a way to integrate more science into the curriculum to meet the standards (Johnson \& Newman, 1993). Teachers and administrators supported the integration of science into the agricultural education curriculum (Johnson \& Newman, 1993). By emphasizing science aspects, the program began to escape its vocational labeling. Thus in 1988 the Future Farmers of American changed its name to the National FFA Organization and vocational agriculture programs started to become agriscience programs (National FFA Organization, 2013, FFA History). To fully incorporate science into agriculture education, a new curriculum was developed.

In 2007, The National Council for Education created The Curriculum for Agriculture Science Education (CASE). The curriculum provided structure for courses, increased rigor, and integrated more science and math into the curriculum (CASE, 2012). These aspects added to the traditional agricultural education program. CASE partnered with Project Lead the Way to support the technical facets of the curriculum, but the curriculum itself was created specifically for agriculture educators. The curriculum, fashioned and written by agriculture educators, ensured the inclusion of the traditional three circle model of the agricultural education program. CASE includes the FFA and SAE in the classroom lessons. However, it is more than lesson plans and lectures for students; it is a total educational program (Retallick, 2012). 
CASE is broken down into different pathways or courses. The pathways include: Animal Science, Plant Science, Agricultural Mechanics, Natural Resources, and Agricultural Business. The CASE curriculum utilizes PowerPoints, teacher notes, student activities, and assessments (CASE, 2012). The creators made sure that the curriculum was not limited to lectures only, but included hands-on activities because they are more effective for student learning. This promotes students to have more advanced knowledge and skill sets when they attend college or start careers. Activities, problems, and projects help students become more engaged in lessons by using inquiry-based learning, a strategy applied to bring math and science concepts to life with the students while acquiring more skills (CASE, 2012). Students who are engaged in lessons are likely to learn more from the lesson (Witt, Ulmer, Burris, Brashears, \& Burley, 2014). CASE also incorporates aspects of English and math (Common Core State Standards Initiative, 2009). The CASE Institute designed the curriculum to align with the Career Cluster Content Standards for math, science, and English created by the National Council for Agricultural education (CASE, 2012). The National Council for Agricultural education created Career Cluster Content Standards (CCCS) to give an idea of what students enrolled in agricultural education classes should be learning (The National Council for Agriculture Education, 2009). CCCS provide a validation for the CASE curriculum aspects in math, science and English. Science is understood more effectively by students with the CASE curriculum (Fillmore, 2012).

There are many parts to the CASE curriculum. Some parts of the curriculum may be new to teachers in the agriculture classroom, such as an emphasis on science. Teachers know that the integration of science in the curriculum is important, even if they do not 
feel comfortable or completely knowledgeable in the area (Boone, H. et. al, 2006). To assist educators, the CASE institute has a professional development training program which certifies teachers to teach the curriculum. Professional development is a mandatory step to using the curriculum. Teachers learn the CASE model components, how CASE was created, and how to use and teach the lesson plans (CASE, 2012). This program was established to thoroughly prepare teachers to teach the curriculum before stepping into their actual classrooms. The professional development training is 80 hours over 10 days (CASE, 2012). The teachers attend the professional development training as students so that they can experience the curriculum first hand (Mensch, 2012). The training is intense, reviewing the entire curriculum for a course into a short amount of time. Teachers become certified after this training in a specific course pathway. The pathways are Animal Science, Plant Science, Agricultural Engineering, Natural Resources and Agribusiness (CASE, 2012). The courses that comprise each pathway are built upon one another. Each pathway is made up of courses specific to that pathway. Each pathway begins with Introduction to Agriculture, Food, and Natural Resources course. 


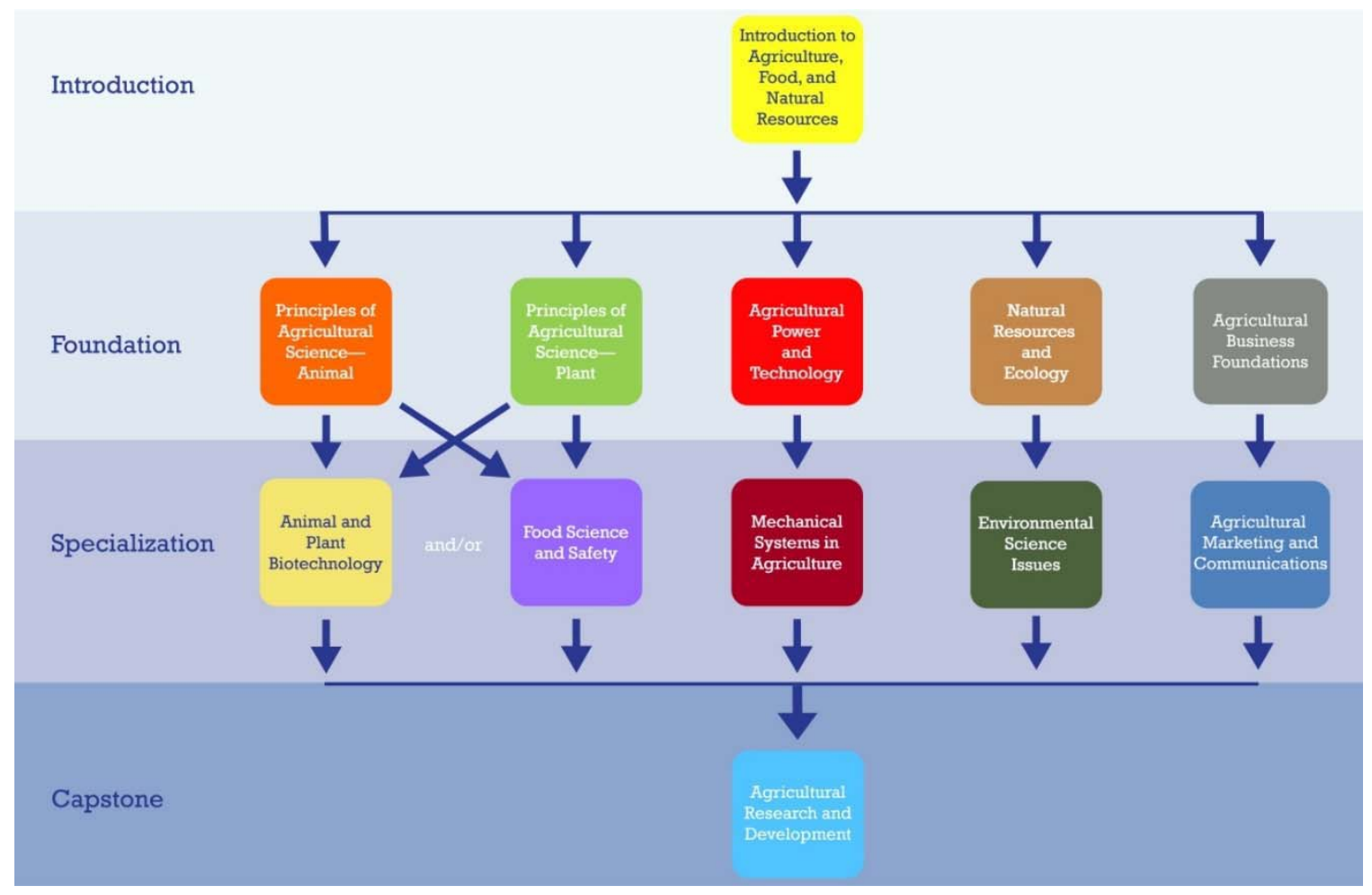

Figure 1: The CASE Model from Understanding the CASE Model (CASE, 2012).

The Animal Science pathway then includes: Principles of Agricultural ScienceAnimal, Animal and Plant Biotechnology or Food Science and Safety. The Plant Science pathway consists of Principles of Agricultural Science- Plant, Animal and Plant Biotechnology, or Food Science and Safety. The Agricultural Engineering pathway includes Agricultural and Power Technology, and Mechanical Systems in Agriculture. The Natural Resources pathway consists of Natural Resources and Ecology, and Environmental Science Issues, and the Agribusiness pathway includes Agricultural Business Foundations, and Agricultural Marketing and Communications. All of the pathways end with the capstone course of Agricultural Research and Development (see Figure 1) (CASE, 2012). Training is rigorous but worth the effort because CASE encompasses how teachers learn and then relays that information to their students (Lamb, 
2012). Teachers find that the CASE training pushes them to work very hard, but afterwards they feel renewed and ready to engage their students (Daniels, 2012).

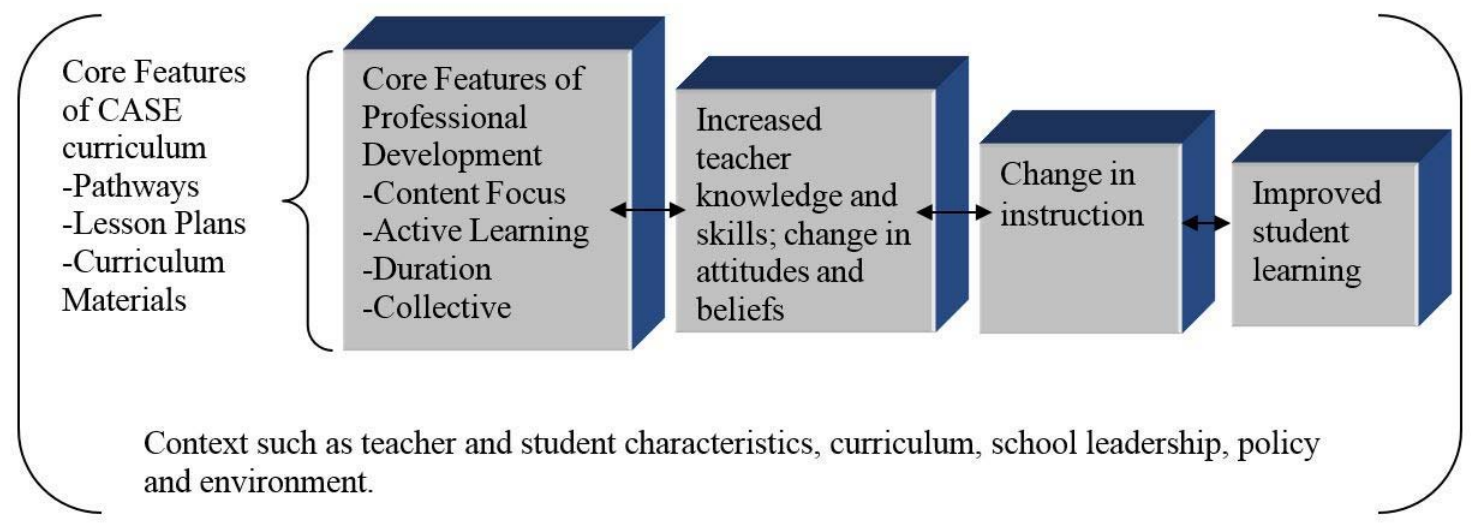

Figure 2: Core Features of CASE and Professional Development Model adapted from proposed core conceptual framework for studying the effects of professional development on teachers and students (Desimone, 2009).

The framework for this study was created using core features from both the CASE curriculum and Desimone's (2009) core features of professional development. Each component plays a key role. The core features of CASE (pathways, lesson plans and supporting materials) line up with the core features of professional development. Desimone (2009) identified the core features of professional development as follows: development, content focus, active learning, coherence, duration and collective participation. These aspects during professional development lead to increased teacher knowledge, which leads to change in teacher instruction and improved student learning (Desimone, 2007). This study focused on all these facets. Surveying educators' perceptions about the process of learning to use CASE will help identify the strengths and weaknesses of the program, or curriculum. 


\section{Problem Statement}

The CASE curriculum has certain components of an all-purpose curriculum for agriculture education. It encompasses the subject matter areas that an agricultural education program needs to grow and develop with students, while staying true to the original agricultural education model. The CASE curriculum engages students in classroom learning and develops more skills for the future (Jansen, 2012). While CASE is a relatively new curriculum, several studies exist which qualitatively evaluate its effectiveness (Witt et. al, 2014). However, no research exists which offer a qualitative analysis of the perceptions of teachers who use the CASE curriculum.

\section{Purpose of the Study}

The purpose of this study was to provide information about the attitudes and perceptions of agricultural educators that have or currently use the CASE curriculum in their classrooms and have completed the CASE professional development. This study also focused on the connection between professional development and classroom and laboratory instruction. The core aspects of professional development which transition from teachers' experiences with development to teaching in the classroom. The following objectives directed this study.

\section{Objectives}

1. To determine the perceptions of educators using the CASE curriculum related to the lesson plans, materials and courses in the curriculum.

2. To determine the perceptions of educators about the CASE curriculum training. 
3. To determine the perceptions of educators on the CASE curriculum as it relates to the total agricultural education model.

4. To determine the perceptions and attitudes of students' views of the CASE curriculum as perceived by their teachers. 


\section{CHAPTER II}

\section{Review of Literature}

\section{Curriculum Development and Evaluation}

In 1918 the Commission of the Reorganization of Secondary Education published the cardinal aims for the American and re-organization of secondary education (NEA, 1918). Seven aims were used to add to the established basic reading, writing, and arithmetic curriculum: health, command of fundamental processes, worthy home membership, vocation, citizenship, worthy use of leisure and ethical character (NEA, 1918). These aims remained the back bone of the curriculum, until the 1950s when education started to move away from the aims. Throughout the world, new educational systems formed bringing with them large curriculum development changes. Educators and administration grew unsatisfied with the methods and materials of current education (Lewy, 1977). The education system contained no hands-on learning; the main focus of

education was on memorization of facts which did little for the problem solving skills and intellectual development of the students (Lewy, 1977). The education system and curriculum needed to change, but to do so, they needed funding. Funds were available and for some education systems, especially in the United States, the only funding available for some schools and only in certain subject areas (Lewy, 1977). Curriculum development and modification of existing curriculum continue to increase in the education system. New curriculum development is a process that could take anywhere from two to five years (Lewy, 1977). 
One widely known curriculum development aspects is the Tyler Rationale. Tyler identified questions that have helped shape many parts of the development process (1949). The questions included (Tyler, 1949):

1. What are the purposes or objectives of the program?

2. What experiences are likely to attain these objectives?

3. How can these experiences be effectively organized?

4. How can the effectiveness of learning be evaluated?

These questions laid the foundation for what curriculum should include and directed the process of development (Girer, 2005). Grier (2005) studied the use of Tyler's questions to develop a curriculum for a local manufacturer's search for skilled workers. Addressing each question, Grier (2005) used interviews, questionnaires and observations to collect the data needed. The developers found that interviews and observations with the manufacturers gave the researchers the information and opinions they needed to form lessons and curricula. The questionnaires gave the interviews and the observations made the data to support the reasoning for certain parts of the curriculum (Grier, 2005). Tyler (1949) provided the basic framework for curriculum development, but noted that one curriculum will not serve every situation. Curriculum is constantly changing and needs to adapt to its audience (Grier, 2005).

The development of curriculum requires numerous hours spent planning and designing. Designing a curriculum is the primary focus in the process. A successful curriculum design must focus on the experiences students need in order to learn (Male, 2012). Within the design of the curriculum, there are three facets: the curriculum of the nation, the curriculum of the school, and the curriculum practiced by children (Male, 
2012). The curriculum of the nation focuses on what the nation as a whole thinks student should learn. The curriculum of the school narrows down to making the experience relevant to the school or area. The curriculum practiced by the children will vary class to class and even child to child (Male, 2012). The 21st century brought on new needs for students. The Qualifications Curriculum Authority asked individuals from teachers, to ministers, to employers, what they thought 21 st century students needed to succeed. The answers given by each individual were very similar. They all agreed that students needed to "be creative, communicate well, be literate and numerate, solve problems, work together well, have a global perspective, show initiative, work independently and be a life-long learner" (Male, 2012, p.25).

The $21^{\text {st }}$ century curriculum is very different from the National Education Association's cardinal aims (1918) and Tyler (1949) principles. Often the view is to keep adding to the existing curriculum. When problems arise in the school systems, e.g. teenage pregnancy, more sexual education classes are added (Noddings, 2007). Noddings (2007) studied the current secondary education curriculum against those traditional aims and found that current curriculums around the world have fallen back into the "memorization of facts" approach. Instead of focusing on learning and using materials, many of the courses focused on fact memorization and subjects are not taught across disciplines (Noddings, 2007). Today, high school is aimed at students getting into college, earning a degree in a specific field, and starting a career. The career they often attain is in a different field than the one they studied (Noddings, 2007). If this is a pattern, why is the curriculum so focused on test scores and narrow subject matter? Noddings (2007) believed the curriculum today has grown too far from the traditional aims. 
Incorporating updated aims based on those traditional aspects would allow students to be well educated as a whole, not just in specific subject areas. Lines between courses need to be more relaxed. Math and science teachers need to incorporate English aspects and vice versa. Students need to be educated, not forced to consume material teachers need to 'cover' (Noddings, 2007). Noddings stated that the aims are the organizing factor in curriculums promoting courses to be intermingled with other courses. When there are bits of each course within others, students can truly start to gain an education (2007).

Part of the change to overlap subject areas between disciplines is the science, technology, engineering and math (STEM) initiative. STEM is a large part of the careers students seek and of the world today (Lawrenz, Huffman \& Thomas, 2006). It is inter disciplinary as it integrates disciplines that were once considered separate (Asunda, 2011). The $21^{\text {st }}$ century continually changes with the development of new technologies, communication methods and teaching strategies (Asunda, 2011). STEM meets this change by educating students in the four areas. Similar to Noddings statement, STEM aims to integrate the four disciplines to solve problems (Asunda, 2011). STEM in the curriculum means an integrated design; the boundaries between specific courses are down (Herschbach, 2011). To successfully use STEM in a classroom curriculum, the options of each subject are kept separate, yet a few aspect of each are taught across the board (Herschbach, 2011). Herschbach (2011) found that one way to implement STEM into existing courses was to use coordinated planning where topics in the specific classes are related to the STEM aspects. Since this method requires adjustments to existing curriculum in the schools, the on-going process of constantly coordinating with other teachers is a downfall (Herschbach, 2011). Broad based curriculum is another option for 
curriculum change by taking courses that are all in the same field of study and creating a larger course using sections of the separate courses (McNeil, 1990). Herschbach (2011) found that the different aspects of the separate courses made broad curriculum models hard to organize. STEM initiative implementations are still changing. Traditional fields become more integrated with knowledge from different disciplines and change how teachers teach their lessons (Herschbach, 2011). Vocational classes, however, remain the same. Instead of using separate courses, parts are taken and related back to STEM to create a more complete course (Herschbach, 2011). Successful implementations of the STEM initiative depend on curriculum design. However, STEM does not always easily fit into existing curriculum. Only by re-forming curriculum to fit the initiative and including activities that link the knowledge to the activity can STEM reach a higher potential in the school system (Herschbach, 2011).

\section{Agricultural Education Curriculum}

Agricultural education has been around since the start of the education system. Even in the early $17^{\text {th }}$ and $18^{\text {th }}$ century agriculture was in schools around the United States (Historical Timeline, 2014). The curriculum has changed and developed over the years, as agricultural education has as well. A part of the agricultural education that has been a large part of the curriculum was the "home-project" or supervised occupational experience (SOE) program in 1908 (Meyers, 2011). The SOE programs were a new aspect to the curriculum. The program was based off of the Kilpatrick project method of teaching Rufus Stimson studied and implemented (Moore, 1988).

Rufus Stimson became the director for Smith's Agricultural School at Northampton school in 1908 (Boone, Doerfert \& Elliot, 1987, p. 58). Stimson started by 
operating a farm and using it for teaching purposes which was uncommon at the time. The school did not have a dormitory and students that came to the farm each day were worried over problems they had at their home farms (Boone, Doerfert \& Elliot, 1987, p. 58). Since the students had home farms and were at school learning on a farm, Stimson did not want students to have problems to worry about they had experienced at school that day. He wanted students to focus on their home farms when they were home and use solutions from management strategies and work ethic learned (Boone, Doerfert \& Elliot, 1987, p. 58). This was the start of the home- projects and matured into the supervised agriculture experience (SAE) programs they are today.

Record keeping became part of the SOE to keep track of the transactions and day to day farming activities. Both parents and students liked the SOEs. Having no dormitory on the campus was appealing to parents because the students got to come home and help on the farm. Students became motivated to keep accurate records and compete in local fairs with their animals (Boone, Doerfert \& Elliot, 1987, p. 59). Over time, the programs developed into the SAE programs that they are today. In 1963, the Vocational Education Act of 1963 had educators include the terms "supervised farming practice" into the current curriculums (Boone, Doerfert \& Elliot, 1987, p. 60). There were several more terminology changes until the result was the SAE term we use today. Although there were inconsistencies from state to state concerning SOEs, the importance of the program was not forgotten.

Boone, Doefert and Elliot (1987) recommended that the SOE program needed promoting and publication to let others become more knowledgeable in the topic. The hands on and problem solving learning approach is an aspect that needs to be pushed in 
the field (Boone, Doerfert \& Elliot, 1987, p. 62). The aspect of hands on learning with problem solving skills has moved and changed with agricultural education over time. Other aspects of the curriculum have changed over the years. The modernizing of the curriculum and integration of biotechnology was an area that was studied by Boone, Gartin, Boone \& Hughes (2006). They found that although many teachers thought that biotechnology needed to be included in the curriculum, many teachers had limited knowledge, but weren't as knowledgeable in the area that they felt comfortable with its incorporation (Boone, Gartin, Boone \& Hughes 2006, p.87). They also did not want to attend meetings constantly and research the area themselves to incorporate in existing curriculum they already had (Boone, Gartin, Boone \& Hughes 2006, p.87). Agricultural education curriculum needed a transformation to keep up with the changing world, somehow that educators could learn about the new curriculum, but still stick to the roots of problem solving and hands on learning. The Curriculum for Agricultural Science Education aimed to incorporate all these aspects for the agricultural education world (CASE, 2012).

\section{CASE Curriculum}

The Curriculum for Agricultural Science Education was formed to include several different aspects into a curriculum. Many different factors drove the creation of CASE. One of those main factors is the STEM initiative to integrate those science, technology, engineering, and math aspects into the agricultural education program (Jansen, 2012). Teachers use the curriculum, but students are the true testers of the curriculum. If the students do not learn or benefit from the curriculum, the program is pointless. Studies exists that show how effective the curriculum is with students. Students who had the 
CASE curriculum in their classrooms are much more engaged in the classroom instruction (Witt, et. al, 2014). They are more interested in the lesson and more on task during the lesson. This means that the CASE curriculum courses more actively involve the students in the activities (Witt, et. al, 2014). The program's effectiveness is also exhibited by how the students reacted to the program. Not only did students' involvement increase, but their grades improved as well (Filimore, 2012). Some teachers classes have classes that earned all A's and B's. They understood more concepts that involved complex and abstract topics (Filimore, 2012). The CASE curriculum includes activities, projects and problems that revolve around the students. They are the ones in control of the outcome of activities (Lamb, 2012). These studies show that CASE is effective, with both teachers and students.

CASE is a huge buzz in agricultural education. It sounds too good to be true, and there are some drawbacks. Teachers reported that the curriculum is harder to implement fully the first year it was introduced into the schools (Lambert \& Elliott, 2012). The CASE curriculum is expensive for schools to fully implement. CASE requires equipment and certain materials essential to its success (Lambert \& Elliott, 2012). To keep CASE in line with the Agricultural education model, teachers need to supplement the aspects of FFA and SAEs (Mensch, 2012). The new curriculum cannot be implemented and changed without training on how to properly and fully implement it (CASE, 2012).

\section{Professional Development}

Education reforms rely on the teacher to learn the new education system, implement it in the school, and increase student's learning (Desimone, 2011). Teachers can learn and implement these curriculum changes before implementing them in the 
classroom through professional development. Professional development is defined as "a vast range of activities and interactions that can increase their knowledge and skills, improve their teaching practice and contribute to their personal, social and emotional growth" (Cohen, McLaughlin \& Talbert, 1993, p. 499). The main focus of professional development is to enhance teachers' knowledge, skills, and practice of application in a classroom environment. Professional development includes seminars, workshops and courses. Observation is also considered professional development because observing their teaching in their own classroom can help evaluate and change behaviors (Desimone, 2011). Desimone, Porter, Garet, Yoon \& Birman (2002) found that the essential features of professional development programs matter more than the actual structure to the program. Desimone (2011) created a framework to represent the specific features of professional development. Content focus, active learning, coherence, duration, and collective participation are the core features to effective professional development (Desimone, 2011).

Bouwma-Gearhart (2012) studied improving teaching practices in postsecondary science. This study documented that while teachers are concerned about their teaching and students learning, programs need to be formed from what the teachers feel they need. Professional development can be also done individually by teachers identifying their individual needs and searching for their own answers to problems in their teaching (Bouwma-Gearthart, 2012). Self-reflection helps teachers continue the professional development process. The key to continuing and growing professional development is the quality. Researchers found that practicing and theoretical orientations are some of the 
effective aspects for science faculty in professional development (Bouwma-Gearhart, 2012).

Kazempour \& Amirshokoohi (2013) also studied teacher's professional development of science teacher's transitioning to inquiry based teaching. There are becoming more professional development workshops and classes for teacher's transitioning to new styles of teaching. In these development experiences, participants often do reflections on the experience. This study used the reflections and assignments in the development classes and seminars. All the teachers felt determined and excited to learn how to better themselves as teachers (Kazempour \& Amirshokoohi, 2013). Each reflection that teachers answered addressed reflecting on their own teaching. The answers many gave reflected on how the professional development affected their teaching and what they can take back to their students to improve their learning (Kazempour \& Amirshokoohi, 2013). One area that highlighted in the reflections focused on their learning style. Teachers learn similar to students and have to experience the learner centered teaching to learn how to implement it (Kazempour \& Amirshokoohi, 2013). Professional development helps teachers develop a support system for their new style of teaching. The teachers in this specific experience felt that they developed a support system with the other teachers they met that they could turn to for help or advice when implementing inquiry teaching in the classroom (Kazempour \& Amirshokoohi, 2013).

Stewart (2014) studied how professional development helps teachers learn and gain positive experiences to take back to the classroom. Teachers take the most away from professional development when they are participating with others that teach the same grade or subject. It helps them build a community and support system for when they 
return to the classroom (Stewart, 2014). Stewart (2014) used Desimone (2009) core features of professional development to create a professional development cycle to continue improving development. The cycle focuses on identifying student learning and needs and translating it to what teacher's should teach (Stewart, 2014).

Professional development does not just take time to design and evaluate, it also takes money. Every year $\$ 1.5$ billion is spent on professional development (Desimone, 2009). With so much money spent, professional development needs to be effective and useful for the individuals using it, especially teachers. The majority of funds and time is spent on developing the courses and seminars for professional development, but little is done to study the teacher's methods of teaching after the development experience (Garet, Porter, Desimone, Birmna \& Yoon, 2001). Blythe (2014) started at the source and studied the "train-the-trainer professional development model on workshop participant's perceptions." Participants at National FFA Convention that attended workshops for the National Agriscience Teacher Ambassador Academy and National Association of Agricultural Educators were used as participants for this study. The objectives of the study included: identifying individual's views on science integration, perceptions of inquiry based instruction, the support of follow up trainings, the relationship of teacher's perceptions of science integration, and the relation and the aspects of professional development used in the workshops (Blythe, 2014). Through a series of questionnaires and focus groups, the results determined that respondents agreed that they acquired new teaching skills from the professional development workshops. They also agreed that the skills they developed help changed their teaching. Key aspects of the professional development were also part of the survey and educators were asked about the duration, 
collective participation, coherence and active participation (Blythe, 2014). Respondents agreed that the duration of the workshops were long enough to gain the skills and abilities and practice them. Respondents also agreed that the professional development matched their beliefs about science integration and their school policies (Blythe, 2014). Overall, respondents were favorable towards science integration in agriculture education. This integration of science into their school resulted in an increase in students enrolled and an increase of higher achieving students. Respondents also agreed that professional development was necessary to develop new skills to use in the classroom (Blythe, 2014).

\section{CASE Curriculum Professional Development}

CASE has support of many educators with its all-inclusive program and materials (CASE, 2012). The lessons, activities, PowerPoints, assessments and notes are all included in the program. The curriculum can be taught as is, or tailored around the agriculture program at the certain school it is being taught at (Mensch, 2012). The program itself is based off of the CASE model which provides support to all the courses in the CASE curriculum (CASE, 2012). CASE also incorporates the inquiry based learning strategies where students can experience and engage in the lessons completely (Witt, et. al, 2014). The courses are sequenced so that the build upon one another and transform the way students are used to learning in the classroom (Schloesser, 2012). The curriculum has so many different aspects, that the training for the curriculum is necessary (Ulmer et. al, 2013).

The training is well received by teachers who attended. It refreshed their teaching and made them excited to take the curriculum home and implement it in their classroom (Dyer, 2012). CASE professional development is intense, but worth the effort because it 
teaches the educator not only how to teach the curriculum but more techniques on using it in the classroom with students (Daniels, 2012). Another highlight of the training is the opportunity to collaborate with other agriculture educators. Support is crucial, especially in the teaching world. Attending the CASE Institute allowed teachers to create a network of others who are going to be using the program in their schools (Mensch, 2012).

\section{Summary}

Curriculum has been growing and changing since the cardinal aims were formed in 1918 (NEA, 1918). Tyler's (1949) questions helped to lead curriculum development towards the main focus of the program and how it can be evaluated. Hands-on learning entered as a part of the curriculum in the education system (Lewy, 1977). To prepare students better for careers and education after high school, more science, hands-on activities and problem solving became integrated in the curriculum. STEM became a large part of integration of new curriculum in schools. STEM facets were not as easily added into the existing curriculum (Asunda, 2011). In agriculture education, CASE curriculum was designed and developed from the STEM. It focuses on hands-on learning and problem solving for students to be able to apply lessons to real life (CASE, 2012). In classrooms where CASE has been used, it has been effective on student's teaching (Fillmore, 2012). New curriculum requires professional development to learn the how to teach the curriculum effectively.

Professional development includes many different facets. The length, context, information and process of the training all matter. From these areas, Desimone (2009) identified core features of what professional development should include. Teachers who had participated in professional development also reported building a support group from 
their peers for when they use their new abilities and skills (Kazempour \& Amirshokoohi, 2013). Integrating science into the curriculum called for professional development seminars and trainings to assist teachers with the transition. In agriculture education, Blythe (2014) studied professional development and teachers perceptions after they had completed it. Teachers favored integrating science and felt that the trainings and time spent at the trainings was appropriate (Blythe, 2014). To use the CASE curriculum in the classroom, educators must go through the training at the CASE Institute before they can use CASE. Teachers who have completed the training agreed that it was intense, but taught them how to use and teach the curriculum (Daniels, 2012). Professional development prepares teachers with skills, abilities and support for their classroom. 


\section{CHAPTER III}

\section{Methods/Procedure}

\section{Purpose of the Study}

The purpose of this study was to provide information about the attitudes and perceptions of agricultural educators that have or currently use the CASE curriculum in their classrooms and have completed the CASE professional development. This study also focused on the connection between professional development and classroom and laboratory instruction. The core aspects of professional development which transition from teachers' experiences with development to teaching in the classroom. The following objectives directed this study.

\section{Objectives}

1. To determine the perceptions of educators using the CASE curriculum related to the lesson plans, materials and courses in the curriculum.

2. To determine the perceptions of educators about the CASE curriculum training.3. To determine the perceptions of educators on the CASE curriculum as it relates to the total agricultural education model.

3. To determine the perceptions and attitudes of students' views of the CASE curriculum as perceived by their teachers.

\section{Research Design}

The design used for the study was descriptive survey research (Ary, Jacobs, Sorensen \& Walker, 2014). Descriptive research allows for a summarization of attitudes 
and opinions towards a topic (Ary, Jacobs, Razavieh \& Sorsenson, 2006). Surveys are a successful way to gather information from a group of people quickly and they are better to use with large groups (Ary, Jacobs, Sorensen \& Walker, 2014). Electronic surveys are quick and efficient when studying the entire population and this survey was structured using Dillman's principles (Dillman, Smith \& Christian, 1999). As the population for this study was large and included educators from all over the United States, an electronic survey was the most efficient way to gather information. Questions were close ended utilizing a Likert type scale to determine the views of educators on the CASE curriculum and its courses. The questions were formed based on Desimone's (2009) core features of professional development and combined with the core features of the CASE curriculum. The theoretical framework model used the features of the CASE curriculum and professional development and connected them to the classroom. Using these aspects from both of these models, the survey was able to accurately measure the attitudes of the population.

\section{Population}

Agricultural educators from all over the United States have been trained in the CASE curriculum. The target population was all the agricultural educators trained in CASE. There were 1,147 individuals trained in the CASE curriculum (CASE, 2012). This study included all of the teachers using CASE in an agricultural education classroom. CASE had a master list of all educators who have been through the professional development training. First, the list was narrowed down by using the individuals who currently teach in the collegiate setting for the pilot study. There were 31 included in this study. The master list also included individuals who did not have an email address or 
members of the CASE curriculum staff. The members of the staff were excluded from the study to avoid a conflict of interest. The educators who did not leave a contact email were also excluded from the study since all participants were contacted via email. After the exclusions, the accessible population for the study was 1,034 educators. Five emails bounced and were undelivered leaving the population at 1,029. A coding system with the email addresses ensured the results remained confidential to the researcher.

\section{Instrumentation}

Likert type statements were used to assess the participant's evaluation of CASE curriculum aspects. Participants had to select if they strongly disagreed, disagreed, somewhat disagreed, somewhat agreed, agreed, and strongly agreed to each statement. West Virginia University's Institutional Review Board approved this study. Using Qualtrics, display logic was applied so individuals only answered questions that pertained to the courses they attending training for. If respondents indicated they had not taught the course they received curriculum instruction for in a classroom, they then answered the demographics questions; the questions pertaining to implementing the course and students' perceptions were not displayed. Each of the eight courses in the CASE curriculum had their own set of statements. This allowed the researcher to discover the attitudes towards professional development training, implementing each individual course in a classroom, courses supporting materials, the courses compared to previous curriculums and the student's views perceived by their teachers specifically related to the CASE curriculum. If respondents indicated they had not applied elements of the curriculum, skip logic was applied to certain questions so they were not shown follow up questions on that topic. The demographics section gathered information about the 
population, and the year respondents first attended the CASE Institute. The sections determined which side of the Likert scale teachers fall on the courses from the CASE curriculum.

\section{Validity and Reliability}

Establishing validity of the instrument is crucial to ensure the instrument and the results are accurate. To establish validity, the instrument has to measure what it is supposed to measure. Face and content validity was established by presenting the instrument to a panel of experts. The panel of experts consisted of Dr. Stacy Gartin, Dr. Jessica Blythe and Dr. Harry Boone.

The instrument cannot be valid without being reliable. A pilot test was conducted with individuals who have been through CASE trainings, but currently teach at the collegiate level. The pilot test was sent out through an anonymous link to the pilot test population. Many corrections were recommended as a result of the pilot test $(n=31)$. There was not sufficient data to conduct a reliability construct, therefore reliability was established using data from the final survey. Spilt-half reliability was used to establish reliability of the instrument. A Spearman- Brown coefficient was calculated for each course within the instrument (see Table 1). All courses exhibited "exemplary" reliability (Robinson, Shaver, \& Wrightsman, 1991). The Agricultural and Power Technology and Agricultural Research and Development courses did not have enough respondents to establish reliability, but overall reliability was used in replace of the courses. The results of the reliability test were as follows: Agriculture, Food and Natural Resources $($ Spearman- Brown $=.888)$, Principles of Agricultural Science- Animal $($ SpearmanBrown $=.834)$, Principles of Agricultural Science - Plant $($ Spearman- Brown $=.832)$, 
Natural Resources and Ecology (Spearman- Brown $=.853$ ), Animal and Plant

Biotechnology $($ Spearman- Brown $=.979)$, and Food Science and Safety (Spearman-

Brown $=.923)$.

Table 1

Reliability of the Instrument

Construct Spearman-Brown Reliability

Coefficient

Introduction to Agriculture, Food and

Natural Resources

$.888 \quad$ Exemplary

Principles of Agricultural Science-

Animal

.834

Exemplary

Principles of Agricultural Science-

Plant

.832

Exemplary

Natural Resources and Ecology

.853

Exemplary

Animal and Plant Biotechnology

.979

Exemplary

Food Science and Safety

.923

Exemplary

When conducting any study there is always room for error. Sample error was avoided by using a census of the population. Frame error deals with the intended population being different from the actual population used for the study. Using the official list given by the CASE program of educators who currently use the program, frame error was avoided. Selection error was avoided by checking the list the survey is sent out to. The list needed to have everyone in the population listed only once. It is important to make sure that individuals are not duplicated from the educators who have completed CASE training and are using the CASE curriculum. This would cause selection error and was easily avoided by making sure everyone is listed only once. 
Measurement error occurs with numeral different errors. The error which was most threatening to this study was measurement error. This happens when the respondents give the answers they think the researcher wants to hear. It was important to make the instrument non biased to let the population know they can be honest with their answers. This error was also minimized by excluding the CASE employees in the study even though they were trained in courses and by making sure the instrument is reliable and valid.

\section{Data Collection Techniques}

A cover letter was sent via email to the population to notify them of the purpose of the survey and to explain how the study ensures confidentiality, show official sponsorship, and set the deadline date. The deadline was set for two weeks from the initial email. After the first deadline, a reminder email gave the non-responders notice to complete the survey. There were two follow up emails before the deadline. The Likert type questions were statistically analyzed to document the educators' views on the areas of the CASE program.

\section{Data Analysis}

Data was analyzed utilizing the SPSS 23.0 for Windows. The level of significance was set a priori at $\alpha<.05$ for all statistical tests. Descriptive statistical analyses appropriate for the respective scales of measurement were performed on the data including measures of central tendency (mean, median, and mode) and variability (frequencies or standard deviation.) The results are represented as frequencies and percentages as well as means, median and mode in both table and narrative form. 


\section{Early and Late Responders}

Respondents were divided into two groups based on the dates of their responses. Those who responded before the first deadline was considered "early respondents" while those who responded after the deadline were considered "late respondents." The respondents who were late respondents are most similar those non respondents (Smith \& Miller, 1983). The analysis for early and late respondents was conducted to provide an estimate of non-response error. A chi-square statistical procedure was used to compare early and late responders on "years used the CASE curriculum," "years teaching," and "highest level of education." The results showed no significant differences, therefore, the results can be generalized to the entire population.

\section{Use of Findings}

The results of this study will be shared with the CASE program and educators to provide perceptions and views of the CASE curriculum and CASE Institute professional development. By establishing a base line of views on these aspects of the program, new teachers will have a more informed idea of how the program is perceived by their peers. The creators and team behind CASE can review how their population views the program and its professional development training. Educators can express their views of the professional development aspect of CASE and its effect in the classroom. The student's views also help future teachers understand how other educators' feelings on their students' attitudes. These results help future educators prepare for the CASE program and what to expect. 


\section{CHAPTER IV}

\section{Findings}

\section{Purpose of the Study}

The purpose of this study was to provide information about the attitudes and perceptions of agricultural educators that have or currently use the CASE curriculum in their classrooms and have completed the CASE professional development. This study also focused on the connection between professional development and classroom and laboratory instruction. The core aspects of professional development which transition from teachers' experiences with development to teaching in the classroom. The following objectives directed this study.

\section{Objectives}

1. To determine the perceptions of educators using the CASE curriculum related to the lesson plans, materials and courses in the curriculum.

2. To determine the perceptions of educators about the CASE curriculum training.

3. To determine the perceptions of educators on the CASE curriculum as it relates to the total agricultural education model.

4. To determine the perceptions and attitudes of students' views of the CASE curriculum as perceived by their teachers.

\section{Results}

The population consisted of all agricultural educators who have completed the CASE institute training and currently teach in a school based high school agriculture classroom. Individuals who have completed the CASE institute training who currently 
teach at the collegiate level, any individuals who worked for CASE and educators who had been through the training but left no contact information were excluded. The accessible population for this study was 1,028 individuals. The final response rate for the study was $52 \%(N=538)$. Reliability for the instrument was conducted and a post-hoc reliability analysis yielded Spearman Brown values that were considered exemplary (Robinson, Shaver, \& Wrightsman, 1991).

The population was asked to identify their demographical information. When asked what gender they best identify with, $41 \%(f=198)$ identified as males and $59 \%(f=$ 288) identified as females (see Table 2). When asked to identify what race they identified with were as follows; $97 \%(f=471)$ white, $.21 \%(f=1)$ Native Hawaiian or Pacific Islander, $.21 \%(f=1)$ black, $.82 \%(f=4)$ other and $2 \%(f=9)$ preferred not to answer. The population was also asked their highest level of education. There were $46 \%$ $(f=221)$ educators with a Bachelor's Degree, $52 \%(f=250)$ educators with a Master's Degree, and 2\% $(f=9)$ educators with a $\mathrm{PhD}$. 
Table 2

Demographic Information: Gender, Race and Level of Education

\begin{tabular}{|c|c|c|}
\hline & $f$ & $\%$ \\
\hline \multicolumn{3}{|l|}{ Gender } \\
\hline Male & 198 & 40.74 \\
\hline Female & 288 & 59.26 \\
\hline Total & 486 & 100.00 \\
\hline \multicolumn{3}{|l|}{ Race } \\
\hline White & 471 & 96.91 \\
\hline Black/African American & 1 & .21 \\
\hline \multicolumn{3}{|l|}{ Native Hawaiian/Pacific } \\
\hline Islander & 1 & .21 \\
\hline Other & 4 & .82 \\
\hline Prefer not to answer & 9 & 1.85 \\
\hline Total & 486 & 100.00 \\
\hline \multicolumn{3}{|l|}{ Level of Education } \\
\hline Bachelor's Degree & 221 & 46.04 \\
\hline Master's Degree & 250 & 52.08 \\
\hline $\mathrm{PhD}$ & 9 & 1.88 \\
\hline Total & 480 & 100.00 \\
\hline
\end{tabular}

Also in the demographical information the respondents were asked in what state they taught (see Table 3). Of the total responding: $16 \%(f=76)$ taught in Iowa, $8 \%(f=$ 42) taught in Washington, $7 \%(f=35)$ taught in Ohio, 6\% $(f=27)$ taught in Indiana, 5\% 
$(f=23)$ taught in Minnesota, 5\% $(f=22)$ taught in Missouri, 4\% $(f=19)$ taught in Nebraska, 4\% $(f=18)$ taught in Kansas, 4\% $(f=18)$ taught in Pennsylvania, 4\% $(f=17)$ taught in New Jersey, 3\% $(f=16)$ taught in Maryland, 3\% $(f=16)$ taught in Texas, 3\% $(f$ $=15)$ taught in Kentucky, 3\% $(f=14)$ taught in Oregon, 3\% $(f=14)$ taught in Tennessee, $3 \%(f=13)$ taught in Illinois, 3\% $(f=13)$ taught in South Dakota, $2 \%(f=12)$ taught in West Virginia, 2\% $(f=11)$ taught in Arkansas, $2 \%(f=10)$ taught in Louisiana, $2 \%(f=$ 10) taught in New York, $1 \%(f=7)$ taught in Michigan, $1 \%(f=6)$ taught in Arizona, $1 \%$ $(f=6)$ taught in Idaho, $1 \%(f=4)$ taught in Florida, .41\% $(f=2)$ taught in California, $.41 \%(f=2)$ taught in North Carolina, .41\% $(f=2)$ taught in North Dakota, $.41 \%(f=2)$ taught in Virginia, .41\% $(f=2)$ taught in Wisconsin, .41\% $(f=2)$ taught in Wyoming, $.41 \%(f=1)$ taught in Alabama, .21\% $(f=1)$ taught in Colorado, $.21 \%(f=1)$ taught in Connecticut, .21\% $(f=1)$ taught in Delaware, .21\% $(f=1)$ taught in Mississippi, .21\% $(f$ $=1)$ taught in Nevada, and $.21 \%(f=1)$ taught in Oklahoma. 
Table 3

States in which Respondents Teach ${ }^{a}$

\begin{tabular}{|c|c|c|c|}
\hline & Total \# trained & $f$ & $\%$ of respondents \\
\hline Iowa & 163 & 76 & 15.73 \\
\hline Washington & 86 & 42 & 8.70 \\
\hline Ohio & 53 & 35 & 7.25 \\
\hline Indiana & 48 & 27 & 5.59 \\
\hline Minnesota & 60 & 23 & 4.76 \\
\hline Missouri & 60 & 22 & 4.55 \\
\hline Nebraska & 46 & 19 & 3.93 \\
\hline Kansas & 47 & 18 & 3.73 \\
\hline Pennsylvania & 27 & 18 & 3.73 \\
\hline New Jersey & 33 & 17 & 3.52 \\
\hline Maryland & 50 & 16 & 3.31 \\
\hline Texas & 46 & 16 & 3.31 \\
\hline Kentucky & 47 & 15 & 3.11 \\
\hline Oregon & 71 & 14 & 2.90 \\
\hline Tennessee & 36 & 14 & 2.90 \\
\hline Illinois & 27 & 13 & 2.69 \\
\hline South Dakota & 21 & 13 & 2.69 \\
\hline West Virginia & 17 & 12 & 2.48 \\
\hline Arkansas & 22 & 11 & 2.28 \\
\hline Louisiana & 27 & 10 & 2.07 \\
\hline New York & 24 & 10 & 2.07 \\
\hline
\end{tabular}


Table 3 (continued)

States in which Respondents Teach ${ }^{a}$

\begin{tabular}{|c|c|c|c|}
\hline & Total \# trained & $f$ & $\%$ of respondents \\
\hline Michigan & 20 & 7 & 1.45 \\
\hline Arizona & 11 & 6 & 1.24 \\
\hline Idaho & 8 & 6 & 1.24 \\
\hline Florida & 15 & 4 & .83 \\
\hline California & 5 & 2 & .41 \\
\hline North Carolina & 4 & 2 & .41 \\
\hline North Dakota & 3 & 2 & .41 \\
\hline Virginia & 4 & 2 & .41 \\
\hline Wisconsin & 5 & 2 & .41 \\
\hline Wyoming & 6 & 2 & .41 \\
\hline Alabama & 3 & 1 & .21 \\
\hline Colorado & 1 & 1 & .21 \\
\hline Connecticut & 5 & 1 & .21 \\
\hline Delaware & 6 & 1 & .21 \\
\hline Mississippi & 1 & 1 & .21 \\
\hline Nevada & 2 & 1 & .21 \\
\hline Oklahoma & 3 & 1 & .21 \\
\hline
\end{tabular}

Note: ${ }^{\text {a }}(n=483)$

Respondents were asked how many years they have used the CASE curriculum in a classroom. Out of the total respondents, $21 \%(f=101)$ have used CASE for less than one year (see Table 4). The number of respondents that have used the curriculum for; 1 year were $7 \%(f=35), 2$ years was $24 \%(f=118), 3$ years was $21 \%(f=103), 4$ years was 
$15 \%(f=74), 5$ years was $7 \%(f=32), 6$ years was $3 \%(f=16), 7$ years was $1 \%(f=5)$, and 8 years was $.21 \%(f=1)$.

Table 4

Years Respondents used CASE Curriculum ${ }^{a}$

\begin{tabular}{lcc}
\hline & $f$ & $\%$ \\
\hline Less than 1 year & 101 & 20.82 \\
1 year & 35 & 7.22 \\
2 years & 118 & 24.33 \\
3 years & 103 & 21.24 \\
4 years & 74 & 15.26 \\
5 years & 32 & 6.60 \\
6 years & 16 & 3.30 \\
7 years & 5 & 1.03 \\
8 years & 1 & .21 \\
9 years & 0 & .00 \\
\hline
\end{tabular}

Note: ${ }^{\mathrm{a}}(n=485)$

The respondents were asked the number of years they have been teaching. Of those responding, 3\% $(f=11)$ had been teaching less than one year, 25\% $(f=119)$ have been teaching 1-4 years (see Table 5). 24\% ( $f=118$ ) have been teaching 5-9 years. $16 \%$ $(f=79)$ of respondents have been teaching 10-14 years. Twelve percent $(f=58)$ have been teaching 15-19 years. Twenty percent $(f=97)$ have been teaching for $20+$ years. 
Table 5

Years Respondents have been Teaching ${ }^{a}$

\begin{tabular}{lcc}
\hline & $f$ & $\%$ \\
\hline Less than 1 year & 11 & 2.28 \\
1-4 years & 119 & 24.69 \\
$5-9$ years & 118 & 24.48 \\
$10-14$ years & 79 & 16.39 \\
$15-19$ years & 58 & 12.03 \\
$20+$ years & 97 & 20.12 \\
\hline
\end{tabular}

Note: ${ }^{\text {a }}(n=482)$

Respondents were asked if they currently use the CASE curriculum in their

classroom. Currently, $90 \%(f=435)$ of those responding were currently using CASE, and $10 \%(f=51)$ were not currently using CASE (see Table 6).

Table 6

Respondents Currently Using the CASE Curriculum ${ }^{a}$

\begin{tabular}{lcc}
\hline & $f$ & $\%$ \\
\hline Yes & 435 & 89.51 \\
No & 51 & 10.49 \\
\hline
\end{tabular}

Note: ${ }^{\mathrm{a}}(n=486)$

Respondents were asked if they were currently certified in an entire CASE

pathway. Of those responding, $86 \%(f=418)$ were not certified in an entire pathway and $14 \%(f=66)$ were certified in an entire pathway (see Table 7). 
Table 7

Respondents Certified in an Entire CASE Pathway ${ }^{a}$

\begin{tabular}{lcc}
\hline & $f$ & $\%$ \\
\hline Yes & 66 & 13.64 \\
No & 418 & 86.36 \\
\hline
\end{tabular}

Note: ${ }^{\text {a }}(n=484)$

The respondents were asked what courses they were trained in and what year they attending the training for them. In 2007, $1 \%(f=3)$ of the respondents attended training for the Introduction to Agriculture, Food and Natural Resources course (see Table 8). In the same year, $1 \%(f=3)$ of the respondents attended training for the Principles of Agricultural Science- Animal course. Three percent $(f=6)$ attended training for the Principles of Agricultural Science- Plant course. Four percent $(f=1)$ attended training for the Agricultural Power and Technology course.

In $2008,1 \%(f=2)$ of the respondents attended training for the Introduction to Agriculture, Food and Natural Resources course. Two percent $(f=4)$ attended training for the Principles of Agricultural Science- Animal course. Of those responding, $1 \%$ ( $f=$ 1) of the respondents attended training for the Principles of Agricultural Science- Plant course. Four percent $(f=1)$ attended training in the Agricultural Power and Technology course.

In $2009, .31 \%$ attended training for the Introduction to Agriculture, Food and Natural Resources course. Of those responding, $2 \%(f=5)$ attended training for the Principles of Agricultural Science-Animal course. Three percent $(f=6)$ of the respondents attended training for the Principles of Agricultural Science- Plant course. 
In $2010,5 \%(f=15)$ of the respondents attended training for the Introduction to Agriculture, Food and Natural Resources course. Of those responding, 2\% $(f=4)$ attended training for the Principles of Agricultural Science- Animal course. Three percent $(f=7)$ of the respondents attended training for the Principles of Agricultural SciencePlant course.

In $2011,7 \%(f=23)$ of the respondents attended training for the Introduction to Agriculture, Food and Natural Resources course. Of those responding, $6 \%(f=14)$ of the respondents attended training for the Principles of Agricultural Science- Animal course. Eight percent $(f=17)$ of the respondents attended training for the Principles of Agricultural Science- Plant course. Of those responding, $4 \%(f=2)$ of the respondents attended training for the Natural Resources and Ecology course. Two percent of those responding $(f=1)$ of the respondents attended training for the Animal and Plant Biotechnology course.

In 2012, 19\% ( $f=59)$ of the respondents attended training for the Introduction to Agriculture, Food and Natural Resources course. Of those respondents, 13\% $(f=29)$ of the respondents attended training for the Principles of Agricultural Science- Animal course. Eleven percent $(f=23)$ of the respondents attended training for the Principles of Agricultural Science- Plant course. Four percent $(f=2)$ of the respondents attended training for the Natural Resources and Ecology course. Nineteen percent $(f=7)$ of the respondents attended training for the Animal and Plant Biotechnology course.

In $2013,22 \%(f=71)$ of the respondents attended training for the Introduction to Agriculture, Food and Natural Resources course. Of those responding, 18\% $(f=40)$ of the respondents attended training for the Principles of Agricultural Science- Animal 
course. Twenty two percent $(f=45)$ of the respondents attended training for the Principles of Agricultural Science- Plant course. Twenty five percent $(f=13)$ of the respondents attended training for the Natural Resources and Ecology course. Twenty four percent of respondents $(f=9)$ of the respondents attended training for the Animal and Plant Biotechnology course. Three percent of respondents $(f=1)$ of the respondents attended training for the Food Science and Safety course. Ten percent $(f=2)$ of the respondents attended training for the Agricultural Research and Development course.

In $2014,22 \%(f=69)$ of the respondents attended training for Introduction to Agriculture, Food and Natural Resources course. Of those responding, 29\% $(f=63)$ of the respondents attended training for the Principles of Agricultural Science- Animal course. Twenty seven percent $(f=56)$ of the respondents attended training for the Principles of Agricultural Science- Plant course. Four percent of the respondents $(f=1)$ of the respondents attended training for the Agricultural Power and Technology course. Of the respondents, $24 \%(f=12)$ of the respondents attended training for the Natural Resources and Ecology course. Thirty respondents $(f=11)$ of the respondents attended training for the Animal and Plant Biotechnology course. Forty nine percent $(f=18)$ of the respondents attended training for the Food Science and Safety course. Ten percent of respondents $(f=2)$ of the respondents attended training for the Agricultural Research and Development course.

In 2015, 22\% ( $f=71)$ attended training for the Introduction to Agriculture, Food and Natural Resources course. Of those who responded, 27\% $(f=61)$ attended training for the Principles of Agricultural Science- Animal course. Twenty two percent $(f=45)$ attended training for the Principles of Agricultural Science- Plant course. Of the 
respondents, $88 \%(f=21)$ of the respondents attended training for Agricultural Power and Technology course. Forty three percent $(f=22)$ of the respondents attended training for the Natural Resources and Ecology course. Twenty four percent $(f=9)$ of the respondents attended training for the Animal and Plant Biotechnology course. Forty nine percent $(f=$ 18) of the respondents attended training for the Food Science and Safety course. Of the respondents, $81 \%(f=17)$ of the respondents attended training for the Agricultural Research and Development course. 
Table 8

Years Respondents Trained in CASE Course

\begin{tabular}{|c|c|c|c|c|c|c|c|c|c|c|c|c|c|c|c|c|}
\hline & \multicolumn{2}{|c|}{ 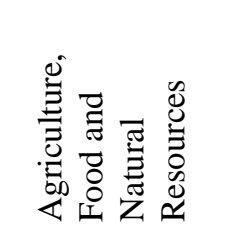 } & \multicolumn{2}{|c|}{ 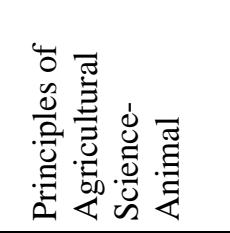 } & \multicolumn{2}{|c|}{ 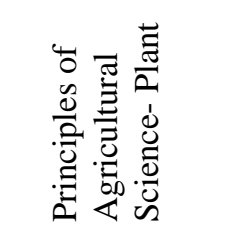 } & \multicolumn{2}{|c|}{ 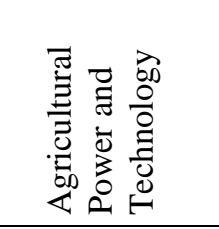 } & \multicolumn{2}{|c|}{ 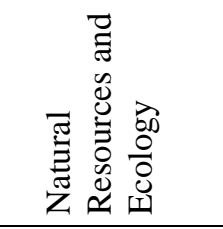 } & \multicolumn{2}{|c|}{ 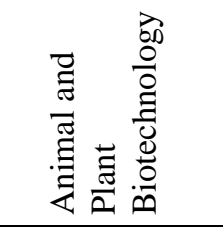 } & \multicolumn{2}{|c|}{ 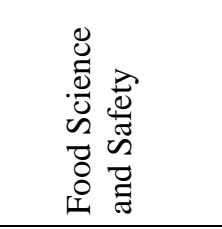 } & \multicolumn{2}{|c|}{ 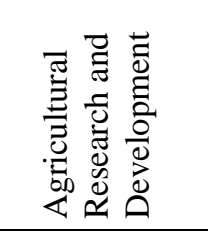 } \\
\hline & $f$ & $\%$ & $f$ & $\%$ & $f$ & $\%$ & $f$ & $\%$ & $f$ & $\%$ & $f$ & $\%$ & $f$ & $\%$ & $f$ & $\%$ \\
\hline 2007 & 3 & .94 & 3 & 1.35 & 6 & 2.91 & 1 & 4.17 & 0 & .00 & 0 & .00 & 0 & .00 & 0 & .00 \\
\hline 2008 & 2 & .63 & 4 & 1.79 & 1 & .49 & 1 & 4.17 & 0 & .00 & 0 & .00 & 0 & .00 & 0 & .00 \\
\hline 2009 & 1 & .31 & 5 & 2.24 & 6 & 2.91 & 0 & .00 & 0 & .00 & 0 & .00 & 0 & .00 & 0 & .00 \\
\hline 2010 & 15 & 4.70 & 4 & 1.79 & 7 & 3.40 & 0 & .00 & 0 & .00 & 0 & .00 & 0 & .00 & 0 & .00 \\
\hline 2011 & 23 & 7.21 & 14 & 6.28 & 17 & 8.25 & 0 & .00 & 2 & 3.92 & 1 & 2.70 & 0 & .00 & 0 & .00 \\
\hline 2012 & 59 & 18.50 & 29 & 13.00 & 23 & 11.17 & 0 & .00 & 2 & 3.92 & 7 & 18.92 & 0 & .00 & 0 & .00 \\
\hline 2013 & 76 & 23.82 & 40 & 17.94 & 45 & 21.84 & 0 & .00 & 13 & 25.49 & 9 & 24.32 & 1 & 2.70 & 2 & 9.52 \\
\hline 2014 & 69 & 21.63 & 63 & 28.25 & 56 & 27.18 & 1 & 4.17 & 12 & 23.53 & 11 & 29.73 & 18 & 48.65 & 2 & 9.52 \\
\hline 2015 & 71 & 22.26 & 61 & 27.35 & 45 & 21.84 & 21 & 87.50 & 22 & 43.14 & 9 & 24.32 & 18 & 48.65 & 17 & 80.95 \\
\hline$n$ & 319 & & 223 & & 206 & & 24 & & 51 & & 37 & & 37 & & 21 & \\
\hline
\end{tabular}


Respondents were asked the question of what courses they have taught or are currently teaching in their classroom. The Introduction to Agriculture, Food and Natural Resources course has 93\% $(f=331)$ respondents trained in it that have used or are currently using the course in their classroom (see Table 9). Seven percent $(f=24)$ of the respondents had not used the Introduction to Agriculture, Food and Natural Resources course. The Principles of Agricultural Science- Animal course has 89\% $(f=205)$ of the respondents who used or currently use the course in a classroom. Of those responding, $11 \%(f=24)$ have not taught the course in their classroom. The Principles of Agricultural Science- Plant course has 77\% $(f=164)$ of respondents trained in the course teaching it or that have taught it in a classroom. Twenty-three percent $(f=48)$ of the respondents trained in that have not taught it in a classroom. The Agricultural Power and Technology course has $86 \%(f=19)$ of the respondents trained in the course who teach it or have taught it in a classroom. Fourteen percent $(f=3)$ of the respondents have not taught the course in a classroom. The Natural Resources and Ecology course has 70\% $(f=37)$ of the respondents trained in it teaching or that have taught it in a classroom. Of the respondents, 30\% $(f=16)$ have not taught the course in a classroom. The Animal and Plant Biotechnology course has 69\% $(f=27)$ respondents who have been trained in the course currently teaching or have taught the course in a classroom. Thirty one percent $(f=$ 12) have not taught the course in a classroom. The Food Science and Safety course has $78 \%(f=28)$ of respondents who have been trained in the course teaching or have taught it in the classroom. Of the respondents, 22\% $(f=8)$ have not taught it in the classroom. The Agricultural Research and Development course has 57\% $(f=12)$ of the 823 
respondents who have been trained in the course, teaching or have taught the course in a classroom. Of the 146 respondents, $43 \%(f=9)$ have not taught the course in a classroom. Table 9

Are you Currently Teaching a CASE Course in your Classroom?

\begin{tabular}{|c|c|c|c|c|c|}
\hline & \multicolumn{2}{|c|}{ Yes } & \multicolumn{2}{|c|}{ No } & \multirow[b]{2}{*}{$n$} \\
\hline & $f$ & $\%$ & $f$ & $\%$ & \\
\hline $\begin{array}{l}\text { Introduction to Agriculture, } \\
\text { Food and Natural Resources } \\
\text { (AFNR) }\end{array}$ & 331 & 93.24 & 24 & 6.76 & 355 \\
\hline $\begin{array}{l}\text { Principles of Agricultural } \\
\text { Science- Animal (ASA) }\end{array}$ & 205 & 88.74 & 26 & 11.26 & 231 \\
\hline $\begin{array}{l}\text { Principle of Agriculture } \\
\text { Science- Plant (ASP) }\end{array}$ & 164 & 77.36 & 48 & 22.64 & 212 \\
\hline $\begin{array}{l}\text { Agricultural Power and } \\
\text { Technology (APT) }\end{array}$ & 19 & 86.36 & 3 & 13.64 & 22 \\
\hline $\begin{array}{l}\text { Natural Resources and } \\
\text { Ecology (NRE) }\end{array}$ & 37 & 69.81 & 16 & 30.19 & 53 \\
\hline $\begin{array}{l}\text { Animal and Plant } \\
\text { Biotechnology (APB) }\end{array}$ & 27 & 69.23 & 12 & 30.77 & 39 \\
\hline $\begin{array}{l}\text { Food Science and Safety } \\
\text { (FSS) }\end{array}$ & 28 & 77.78 & 8 & 22.22 & 36 \\
\hline $\begin{array}{l}\text { Agricultural Research and } \\
\text { Development (ARD) }\end{array}$ & 12 & 57.14 & 9 & 42.86 & 21 \\
\hline
\end{tabular}

Respondents were asked in which courses they have been trained. Of the respondents, $66 \%(f=355)$ attended training for the Introduction to Agriculture, Food and Natural Resources course (see Table 10). Of the 538 respondents, $34 \%(f=183)$ of the respondents had not attended training for the course. The Principles of Agricultural Science- Animal course had 46\% $(f=247)$ respondents that attended training for the 
course. Fifty-four percent $(f=291)$ of the respondents had not attended training for the course. The Principles of Agricultural Science- Plant had 44\% $(f=237)$ of the respondents trained in the course, $56 \%(f=301)$ of the respondents were not trained in the course. The Agricultural Power and Technology course had 5\% $(f=24)$ trained in the course, $96 \%(f=514)$ were not trained in the course. The Natural Resources course had $11 \%(f=58)$ of the respondents trained in the course, $89 \%(f=480)$ were not trained in the course. The Animal and Plant Biotechnology course had 8\% $(f=45)$ of the respondents trained in the course, $92 \%(f=493)$ were not trained in the course. The Food Science and Safety course had 7\% $(f=40)$ respondents trained in the course, $93 \%(f=$ 498) were not trained in the course. The Agricultural Research and Development course had $4 \%(f=23)$ trained in the course, $96 \%(f=515)$ were not trained in the course.

\section{Introduction to Agriculture, Food and Natural Resources (AFNR)}

Respondents were asked about the training for the Introduction to Agriculture, Food and Natural Resources course. When asked about their feelings after the training, $3 \%(f=8)$ strongly disagreed that the training prepared them for implementing the AFNR course (see Table 11). Of those respondents, $1 \%(f=2)$ disagreed, $.31 \%(f=1)$ somewhat disagreed, $5 \%(f=17)$ somewhat agreed, $41 \%(f=132)$ agreed, and $51 \%(f=$ 164) of the respondents strongly agreed. Respondents were asked the degree to which they agreed and disagreed for the trainings preparation to use the lesson plans in the classroom. Of those who responded, $3 \%(f=8)$ strongly disagreed, $.31 \%(f=1)$ disagreed, $.31 \%(f=1)$ somewhat disagreed, $6 \%(f=18)$ somewhat agreed, $39 \%(f=127)$ agreed, and 52\% $(f=169)$ strongly agreed. Respondents were asked the degree to which they agreed and disagreed that the training prepared them to use the PowerPoints for the 
course. Three percent $(f=8)$ strongly disagreed, $1 \%(f=3)$ disagreed, $3 \%(f=10)$ somewhat disagreed, $13 \%(f=42)$ somewhat agreed, $40 \%(f=128)$ agreed, and $41 \%(f=$ $133)$.

Table 10

CASE Courses Respondents were Currently Trained ${ }^{a}$

\begin{tabular}{lcccc}
\hline & \multicolumn{2}{c}{ No } & \multicolumn{2}{c}{ Yes } \\
\cline { 2 - 5 } & $f$ & $\%$ & $\%$ \\
\hline $\begin{array}{l}\text { Introduction to Agriculture, } \\
\text { Food and Natural Resources }\end{array}$ & 183 & 34.01 & 355 & 65.99 \\
Agricultural Science - Animal & 291 & 54.09 & 247 & 45.91 \\
Agricultural Science-Plant & 301 & 55.95 & 237 & 44.05 \\
Agricultural Power and & & & 24 & 4.46 \\
Technology & 514 & 95.54 & & 10.78 \\
$\begin{array}{l}\text { Natural Resources and } \\
\text { Technology }\end{array}$ & 480 & 89.22 & 58 & 8.36 \\
Animal and Plant Biotechnology & 493 & 91.64 & 45 & 7.43 \\
Food Science and Safety & 498 & 92.57 & 40 & 4.28 \\
Agricultural Research and & & & & \\
Development & 515 & 95.72 & 23 & \\
\hline Note: (n= 538) & & & & \\
\hline
\end{tabular}

Note: ${ }^{\text {a }}(n=538)$ 
Table 11

CASE Training Prepared Individuals to: ${ }^{a}$

\begin{tabular}{|c|c|c|c|c|c|c|c|c|c|c|c|c|}
\hline & \multicolumn{2}{|c|}{$\begin{array}{l}\text { Strongly } \\
\text { Disagree }\end{array}$} & \multicolumn{2}{|c|}{ Disagree } & \multicolumn{2}{|c|}{$\begin{array}{l}\text { Somewhat } \\
\text { Disagree }\end{array}$} & \multicolumn{2}{|c|}{ Somewhat Agree } & \multicolumn{2}{|c|}{ Agree } & \multicolumn{2}{|c|}{ Strongly Agree } \\
\hline & $f$ & $\%$ & $f$ & $\%$ & $f$ & $\%$ & $f$ & $\%$ & $f$ & $\%$ & $f$ & $\%$ \\
\hline Implement the & & & & & & & & & & & & \\
\hline AFNR CASE course & 8 & 2.47 & 2 & .62 & 1 & .31 & 17 & 5.25 & 132 & 40.74 & 164 & 50.62 \\
\hline $\begin{array}{l}\text { Use the CASE } \\
\text { curriculum AFNR } \\
\text { course lesson plans }\end{array}$ & 8 & 2.47 & 1 & .31 & 1 & .31 & 18 & 5.56 & 127 & 39.20 & 169 & 52.16 \\
\hline $\begin{array}{l}\text { Use the AFNR } \\
\text { course CASE Power } \\
\text { Points }\end{array}$ & 8 & 2.47 & 3 & .93 & 10 & 3.09 & 42 & 12.96 & 128 & 39.51 & 133 & 41.05 \\
\hline
\end{tabular}

Note: ${ }^{\text {a }}(n=324)$ 
Respondents were asked if they required assistance from CASE support staff in implementing the CASE course AFNR in their classroom. Of those responding, $18 \%(f=$ 59) required assistance, $82 \%(f=264)$ did not (see Table 12).

Table 12

Respondents Who Required Assistance from CASE When Implementing the Course in a Classroom $^{a}$

\begin{tabular}{lcc}
\hline & $f$ & $\%$ \\
\hline Yes & 59 & 18.27 \\
No & 264 & 81.73 \\
\hline
\end{tabular}

Note: ${ }^{\text {a }}(n=323)$

The respondents who required assistance from CASE support staff when implementing the AFNR course were given statements and asked the extent to which they agreed or disagreed. When given the statement "I received assistance from a CASE staff member or lead teacher when implementing the CASE curriculum," $6 \%(f=3)$ strongly disagreed, $6 \%(f=3)$ disagreed, $4 \%(f=2)$ somewhat disagreed, $15 \%(f=8)$ somewhat agreed, $46 \%(f=25)$ agreed, and 24\% ( $f=13)$ strongly agreed (see Table 13$)$. When given the statement, "The professional development was helpful for problems that arose over time using the curriculum," $2 \%(f=1)$ strongly disagreed, $2 \%(f=1)$ disagreed, $4 \%(f=2)$ somewhat disagreed, 33\% $(f=18)$ somewhat agreed, $39 \%(f=21)$ agreed, and $20 \%(f=11)$ strongly agreed. When given the statement "The professional development aspect involved interactions through the National Association of Agricultural Educators Community of Practice Forum," 6\% $(f=3)$ disagreed, $4 \%(f=2)$ somewhat agreed, $28 \%(f=15)$ somewhat agreed, $41 \%(f=22)$ agreed, and $22 \%(f=12)$ strongly agreed. 
Table 13

Aspects of Post CASE Training Assistance ${ }^{a}$

\begin{tabular}{|c|c|c|c|c|c|c|c|c|c|c|c|c|}
\hline & \multicolumn{2}{|c|}{$\begin{array}{l}\text { Strongly } \\
\text { Disagree }\end{array}$} & \multicolumn{2}{|c|}{ Disagree } & \multicolumn{2}{|c|}{$\begin{array}{l}\text { Somewhat } \\
\text { Disagree }\end{array}$} & \multicolumn{2}{|c|}{ Somewhat Agree } & \multicolumn{2}{|c|}{ Agree } & \multicolumn{2}{|c|}{ Strongly Agree } \\
\hline & $f$ & $\%$ & $f$ & $\%$ & $f$ & $\%$ & $f$ & $\%$ & $f$ & $\%$ & $f$ & $\%$ \\
\hline $\begin{array}{l}\text { Received assistance } \\
\text { from a CASE staff } \\
\text { member or lead } \\
\text { teacher }\end{array}$ & 3 & 5.56 & 3 & 5.56 & 2 & 3.70 & 8 & 14.81 & 25 & 46.30 & 13 & 24.07 \\
\hline $\begin{array}{l}\text { Helpful for problems } \\
\text { that arose over time } \\
\text { using the curriculum }\end{array}$ & 1 & 1.85 & 1 & 1.85 & 2 & 3.70 & 18 & 33.33 & 21 & 38.89 & 11 & 20.37 \\
\hline $\begin{array}{l}\text { Involved interactions } \\
\text { through the National } \\
\text { Association of } \\
\text { Agricultural } \\
\text { Educators } \\
\text { Community of } \\
\text { Practice Forum }\end{array}$ & 0 & .00 & 3 & 5.56 & 2 & 3.70 & 15 & 27.78 & 22 & 40.74 & 12 & 22.22 \\
\hline
\end{tabular}


Respondents were asked how they felt in their classrooms after the CASE training. When given the statement, "I was comfortable using the curriculum in the classroom," $1 \%(f=2)$ disagreed, $1 \%(f=3)$ somewhat disagreed, $10 \%(f=31)$ somewhat agreed, 44\% $(f=132)$ agreed and 44\% $(f=133)$ strongly agreed (see Table 14). When given the statement, "my knowledge and skills of the material increased from the training," .33\% $(f=1)$ strongly disagreed, $.33 \%(f=1)$ disagreed, $2 \%(f=5)$ somewhat disagreed, $10 \%(f=30)$ somewhat agreed, $38 \%(f=114)$ agreed, and $50 \%(f=$ 149) strongly agreed. When given the statement, "the training led to a positive change in their instruction," .33\% $(f=1)$ strongly disagreed, $1 \%(f=3)$ disagreed, $.33 \%(f=1)$ somewhat disagreed, $17 \%(f=51)$ somewhat agreed, $381 \%(f=93)$ agreed, $50 \%(f=$ 151) strongly agreed. When given the statement concerning their students improve learning, $.33 \%(f=1)$ strongly disagreed, $.33 \%(f=1)$ disagreed, $3 \%(f=8)$ somewhat disagreed, 25\% $(f=74)$ somewhat agreed, 34\% $(f=101)$ agreed, 38\% $(f=114)$ strongly agreed. 
Table 14

\section{Post CASE Training}

\begin{tabular}{|c|c|c|c|c|c|c|c|c|c|c|c|c|c|}
\hline & \multicolumn{2}{|c|}{$\begin{array}{l}\text { Strongly } \\
\text { Disagree }\end{array}$} & \multicolumn{2}{|c|}{ Disagree } & \multicolumn{2}{|c|}{$\begin{array}{l}\text { Somewhat } \\
\text { Disagree }\end{array}$} & \multicolumn{2}{|c|}{$\begin{array}{l}\text { Somewhat } \\
\text { Agree }\end{array}$} & \multicolumn{2}{|c|}{ Agree } & \multicolumn{2}{|c|}{ Strongly Agree } & \multirow[b]{2}{*}{$n$} \\
\hline & $f$ & $\%$ & $f$ & $\%$ & $f$ & $\%$ & $f$ & $\%$ & $f$ & $\%$ & $f$ & $\%$ & \\
\hline $\begin{array}{l}\text { I was comfortable } \\
\text { using the } \\
\text { curriculum in the } \\
\text { classroom. }\end{array}$ & 0 & .00 & 2 & .66 & 3 & 1.00 & 31 & 10.30 & 132 & 43.85 & 133 & 44.19 & 301 \\
\hline $\begin{array}{l}\text { My knowledge and } \\
\text { skills of the } \\
\text { material increased } \\
\text { from the training. }\end{array}$ & 1 & .33 & 1 & .33 & 5 & 1.67 & 30 & 10.00 & 114 & 38.00 & 149 & 49.67 & 300 \\
\hline $\begin{array}{l}\text { The training led to } \\
\text { a positive change in } \\
\text { my instruction. }\end{array}$ & 1 & .33 & 3 & 1.00 & 1 & .33 & 51 & 17.00 & 93 & 31.00 & 151 & 50.33 & 300 \\
\hline $\begin{array}{l}\text { My students } \\
\text { learning improved. }\end{array}$ & 1 & .33 & 1 & .33 & 8 & 2.68 & 74 & 24.75 & 101 & 33.78 & 114 & 38.13 & 299 \\
\hline
\end{tabular}


Respondents were asked the extent to which they agreed or disagreed with statements concerning the CASE AFNR lesson plans. When given the statement," The AFNR course CASE lesson plans are user friendly to anyone who tries to use them," $.33 \%(f=1)$ disagreed, $2 \%(f=6)$ somewhat disagreed, $20 \%(f=60)$ somewhat agreed, $47 \%(f=142)$ agreed, $31 \%(f=92)$ strongly agreed (see Table 15$)$. When given the statement, "The AFNR course CASE lesson plans \& contain the material to be taught in each lesson," $1 \%(f=2)$ strongly disagreed, $3 \%(f=10)$ somewhat disagreed, $13 \%(f=$ 39) somewhat agreed, $47 \%(f=141)$ agreed, and 36\% $(f=109)$ strongly agreed. When given the statement, "The AFNR course CASE lesson plans contain the material to be taught in each unit," $1 \%(f=2)$ strongly disagreed, . $33 \%(f=1)$ disagreed, $2 \%(f=5)$ somewhat disagreed, $14 \%(f=41)$ somewhat agreed, $46 \%(f=137)$ agreed, and $38 \%(f=$ 114) strongly agreed. When given the statement, "The AFNR course CASE lesson plans overall contain the needed amount of material," $.33 \%(f=1)$ strongly disagreed, $1 \%(f=$ 2) somewhat disagreed, $3 \%(f=8)$ disagreed, $185(f=54)$ somewhat agreed, $36 \%(f=$ 139) agreed, and $32 \%(f=97)$ strongly agreed. 
Table 15

\section{CASE AFNR Lesson Plans}

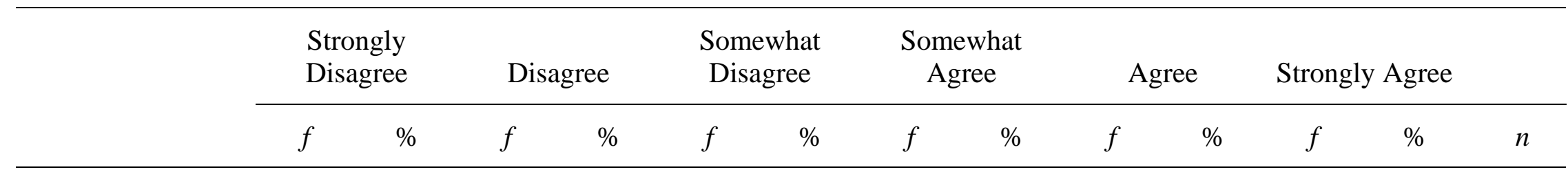

Plans are user friendly to anyone who tries to use them.

material to be taught in each lesson.

Plans contain the material to be taught in each unit. $2 \quad .67$

.67

$1 \quad .33$

$5 \quad 1.67$

Plans overall contain the needed amount of material.

.33

2

\begin{tabular}{llllllllll}
.66 & 8 & 2.66 & 54 & 17.94 & 139 & 46.18 & 97 & 32.23 & 301 \\
\hline
\end{tabular}


Respondents were asked to what degree they agreed or disagreed with the incorporation of parts of the Agricultural education model in the CASE curriculum as opposed to previous curriculums. For classroom and laboratory, $11 \%(f=32)$ agreed that its incorporation was equal to previous curriculums, 53\% $(f=157)$ agreed that its incorporation was superior and $36 \%(f=106)$ agreed that its incorporation was definitely superior (see Table 16). For FFA and leadership incorporation, $6 \%(f=17)$ agreed that CASE's incorporation was definitely inferior, 32\% $(f=93)$ agreed that it was inferior, $41 \%(f=122)$ agreed that it was equal to, $14 \%(f=42)$ agreed that it was superior, and $7 \%(f=21)$ agreed that it was definitely superior. For Supervised Agriculture Experience (SAE), 5\% $(f=14)$ agreed that CASE's incorporation was definitely inferior, $28 \%(f=$ $81)$ agreed that the incorporation was inferior, $45 \%(f=132)$ agreed that it was equal to, $17 \%(f=51)$ agreed that it was superior, and 6\% $(f=17)$ agreed that it was definitely superior. Concerning CASE's incorporation of all aspects of an Agricultural education Program, $.34 \%(f=1)$ agreed that its incorporation was definitely inferior, $6 \%(f=18)$ agreed that it was inferior, $45 \%(f=132)$ agreed it was equal to, $17 \%(f=51)$ agreed that it was superior, and $6 \%(f=17)$ agreed that it was definitely superior. 
Table 16

CASE Incorporation of Parts of the Agricultural Education Model

\begin{tabular}{|c|c|c|c|c|c|c|c|c|c|c|c|}
\hline & \multicolumn{2}{|c|}{ Definitely Inferior } & \multicolumn{2}{|c|}{ Inferior } & \multicolumn{2}{|c|}{ Equal To } & \multicolumn{2}{|c|}{ Superior } & \multicolumn{2}{|c|}{$\begin{array}{l}\text { Definitely } \\
\text { Superior }\end{array}$} & \multirow[b]{2}{*}{$n$} \\
\hline & $f$ & $\%$ & $f$ & $\%$ & $f$ & $\%$ & $f$ & $\%$ & $f$ & $\%$ & \\
\hline $\begin{array}{l}\text { Classroom and } \\
\text { laboratory }\end{array}$ & 0 & .00 & 0 & .00 & 32 & 10.85 & 157 & 53.22 & 106 & 35.93 & 295 \\
\hline FFA and leadership & 17 & 5.76 & 93 & 31.53 & 122 & 41.36 & 42 & 14.24 & 21 & 7.12 & 295 \\
\hline $\begin{array}{l}\text { Supervised Agriculture } \\
\text { Experiences (SAE) }\end{array}$ & 14 & 4.75 & 81 & 27.46 & 132 & 44.75 & 51 & 17.29 & 17 & 5.76 & 295 \\
\hline $\begin{array}{l}\text { All aspects of an } \\
\text { Agricultural education } \\
\text { Program }\end{array}$ & 1 & .34 & 18 & 6.14 & 97 & 33.11 & 147 & 50.17 & 30 & 10.24 & 293 \\
\hline
\end{tabular}


Respondents were asked the degree to which they agreed or disagreed with statements concerning their student's perceptions of the CASE curriculum AFNR course. When given the statement, "Students enjoyed the creativity of the AFNR course lessons," $.33 \%(f=1)$ strongly disagreed, $1 \%(f=2)$ disagreed, $3 \%(f=8)$ somewhat disagreed, $30 \%(f=91)$ somewhat agreed, $46 \%(f=137)$ agreed, and $20 \%(f=61)$ strongly agreed (see Table 17). When given the statement, "Students enjoyed the spontaneity of the AFNR course lessons," .33\% $(f=1)$ strongly disagreed, $3 \%(f=8)$ disagreed, $8 \%(f=23)$ somewhat disagreed, $29 \%(f=86)$ somewhat agreed, 44\% $(f=133)$ agreed, $16 \%(f=49)$ strongly agreed. When given the statement, "Students enjoyed the AFNR course," .34\% $(f=1)$ strongly disagreed, $.34 \%(f=1)$ disagreed, $3 \%(f=8)$ somewhat disagreed, $22 \%(f$ $=65)$ somewhat agreed, $56 \%(f=165)$ agreed, and $19 \%(f=57)$ strongly agreed. 
Table 17

Student Perceptions of CASE Creativity as Perceived by Their Teachers

\begin{tabular}{|c|c|c|c|c|c|c|c|c|c|c|c|c|c|}
\hline & \multicolumn{2}{|c|}{$\begin{array}{l}\text { Strongly } \\
\text { Disagree }\end{array}$} & \multicolumn{2}{|c|}{ Disagree } & \multicolumn{2}{|c|}{$\begin{array}{l}\text { Somewhat } \\
\text { Disagree }\end{array}$} & \multicolumn{2}{|c|}{$\begin{array}{c}\text { Somewhat } \\
\text { Agree }\end{array}$} & \multicolumn{2}{|c|}{ Agree } & \multicolumn{2}{|c|}{ Strongly Agree } & \multirow[b]{2}{*}{$n$} \\
\hline & $f$ & $\%$ & $f$ & $\%$ & $f$ & $\%$ & $f$ & $\%$ & $f$ & $\%$ & $f$ & $\%$ & \\
\hline $\begin{array}{l}\text { Students enjoyed } \\
\text { the creativity of the } \\
\text { AFNR course } \\
\text { lessons. }\end{array}$ & 1 & .33 & 2 & .67 & 8 & 2.67 & 91 & 30.33 & 137 & 45.67 & 61 & 20.33 & 300 \\
\hline $\begin{array}{l}\text { Students enjoyed } \\
\text { the spontaneity of } \\
\text { the AFNR course } \\
\text { lessons. }\end{array}$ & 1 & .33 & 8 & 2.67 & 23 & 7.67 & 86 & 28.67 & 133 & 44.33 & 49 & 16.33 & 300 \\
\hline $\begin{array}{l}\text { Students enjoyed } \\
\text { the AFNR course. }\end{array}$ & 1 & .34 & 1 & .34 & 8 & 2.69 & 65 & 21.89 & 165 & 55.56 & 57 & 19.19 & 297 \\
\hline
\end{tabular}


Respondents were asked to select a number from 1-100 to represent the level of student's positive excitement over time for the CASE curriculum AFNR course. For student's positive level of excitement at the beginning of the course, the mean was 60.80 and the standard deviation was 25.07 (see Table 18). For student's positive excitement in the middle of the course, the mean was 65.92 with the standard deviation of 17.90 . For student's positive excitement at the end of the course, the mean was 73.99 and the standard deviation was 19.59 .

Table 18

Students' Levels of Positive Excitement Over Time

M SD

Students' positive excitement at the beginning of the course.

60.80

25.07

Students' positive excitement in the middle of course.

Students' positive excitement at the end of the course.

Average

66.90

20.85

\section{Principles of Agricultural Science- Animal (ASA)}

Respondents were asked about the training for the Principles of Agricultural Science- Animal course. When asked about their feelings about the training, $2 \%(f=4)$ strongly disagreed that the training prepared them for implementing the ASA course (see Table 19). Of those responding, $2 \%(f=3)$ somewhat disagreed, $6 \%(f=12)$ somewhat agreed, $46 \%(f=91)$ agreed, and $44 \%$ of the respondents $(f=88)$ strongly agreed. 
Respondents were asked the degree to which they agreed and disagreed with the trainings preparation to use the lesson plans in the classroom. Of those who responded, $2 \%(f=4)$ strongly disagreed, $2 \%(f=3)$ somewhat disagreed, $7 \%(f=14)$ somewhat agreed, $44 \%(f$ $=87)$ agreed, and $45 \%(f=89)$ strongly agreed. Respondents were asked the degree they agreed or disagreed that the training prepared them to use the Power Points in the classroom. Two percent $(f=4)$ strongly disagreed, $3 \%(f=6)$ somewhat disagreed, $12 \%$ $(f=23)$ somewhat agreed, $46 \%(f=90)$ agreed, and $38 \%(f=74)$. 
Table 19

The CASE Training Prepared Individuals to:

\begin{tabular}{|c|c|c|c|c|c|c|c|c|c|c|c|c|c|}
\hline & \multicolumn{2}{|c|}{$\begin{array}{l}\text { Strongly } \\
\text { Disagree }\end{array}$} & \multicolumn{2}{|c|}{ Disagree } & \multicolumn{2}{|c|}{$\begin{array}{l}\text { Somewhat } \\
\text { Disagree }\end{array}$} & \multicolumn{2}{|c|}{$\begin{array}{c}\text { Somewhat } \\
\text { Agree }\end{array}$} & \multicolumn{2}{|c|}{ Agree } & \multicolumn{2}{|c|}{ Strongly Agree } & \multirow[b]{2}{*}{$n$} \\
\hline & $f$ & $\%$ & $f$ & $\%$ & $f$ & $\%$ & $f$ & $\%$ & $f$ & $\%$ & $f$ & $\%$ & \\
\hline Implement the ASA & & & & & & & & & & & & & \\
\hline CASE course & 4 & 2.02 & 0 & .00 & 3 & 1.52 & 12 & 6.06 & 91 & 45.96 & 88 & 44.44 & 198 \\
\hline $\begin{array}{l}\text { Use the CASE } \\
\text { curriculum ASA } \\
\text { course lesson plans }\end{array}$ & 4 & 2.03 & 0 & .00 & 3 & 1.52 & 14 & 7.11 & 87 & 44.16 & 89 & 45.18 & 197 \\
\hline $\begin{array}{l}\text { Use the ASA } \\
\text { course CASE } \\
\text { Power Points } \\
\text { included in the } \\
\text { curriculum }\end{array}$ & 4 & 2.03 & 0 & .00 & 6 & 3.05 & 23 & 11.68 & 90 & 45.69 & 74 & 37.56 & 197 \\
\hline
\end{tabular}


Respondents were asked if they required assistance from CASE support staff in implementing the CASE course ASA in their classroom. Of those responding, $24 \%(f=$ 48) required assistance, and $76 \%(f=149)$ did not (see Table 20).

Table 20

Respondents Who Required Assistance from CASE When Implementing the Course in a Classroom $^{a}$

\begin{tabular}{lcc}
\hline & $f$ & $\%$ \\
\hline Yes & 48 & 24.37 \\
No & 149 & 75.63 \\
\hline
\end{tabular}

Note: ${ }^{\text {a }}(n=197)$

The respondents who required assistance from CASE support staff when implementing the ASA course were given statements, and asked the extent to which they agreed or disagreed. When given the statement "I received assistance from a CASE staff member or lead teacher when implementing the CASE curriculum," $13 \%(f=6)$ disagreed, $4 \%(f=2)$ somewhat disagreed, $9 \%(f=4)$ somewhat agreed, $47 \%(f=22)$ agreed, and $28 \%(f=13)$ strongly agreed (see Table 21$)$. When given the statement, "The professional development was helpful for problems that arose over time using the curriculum," 4\% $(f=2)$ disagreed, 9\% $(f=4)$ somewhat disagreed, 19\% $(f=9)$ somewhat agreed, $43 \%(f=20)$ agreed, and 26\% $(f=12)$ strongly agreed. When given the statement "The professional development aspect involved interactions through the National Association of Agricultural Educators Community of Practice Forum," 4\% $(f=2)$ disagreed, $6 \%(f=3)$ somewhat disagreed, $19 \%(f=9)$ somewhat agreed, $45 \%(f=21)$ agreed, and $26 \%(f=12)$ strongly agreed. 
Table 21

Aspects of Post CASE Training Assistance ${ }^{a}$

\begin{tabular}{|c|c|c|c|c|c|c|c|c|c|c|c|c|}
\hline & \multicolumn{2}{|c|}{$\begin{array}{l}\text { Strongly } \\
\text { Disagree }\end{array}$} & \multicolumn{2}{|c|}{ Disagree } & \multicolumn{2}{|c|}{$\begin{array}{l}\text { Somewhat } \\
\text { Disagree }\end{array}$} & \multicolumn{2}{|c|}{ Somewhat Agree } & \multicolumn{2}{|c|}{ Agree } & \multicolumn{2}{|c|}{ Strongly Agree } \\
\hline & $f$ & $\%$ & $f$ & $\%$ & $f$ & $\%$ & $f$ & $\%$ & $f$ & $\%$ & $f$ & $\%$ \\
\hline $\begin{array}{l}\text { CASE staff member } \\
\text { or lead teacher when } \\
\text { implementing the }\end{array}$ & & & & & & & & & & & & \\
\hline CASE curriculum & 0 & .00 & 6 & 12.77 & 2 & 4.26 & 4 & 8.51 & 22 & 46.81 & 13 & 27.66 \\
\hline $\begin{array}{l}\text { Helpful for problems } \\
\text { that arose over time } \\
\text { using the curriculum }\end{array}$ & 0 & .00 & 2 & 4.26 & 4 & 8.51 & 9 & 19.15 & 20 & 42.55 & 12 & 25.53 \\
\hline $\begin{array}{l}\text { Interactions through } \\
\text { the National } \\
\text { Association of } \\
\text { Agricultural } \\
\text { Educators } \\
\text { Community of } \\
\text { Practice Forum }\end{array}$ & 0 & .00 & 2 & 4.26 & 3 & 6.38 & 9 & 19.15 & 21 & 44.68 & 12 & 25.53 \\
\hline
\end{tabular}


Respondents were asked how they felt in their classrooms after the CASE training. When given the statement, "I was comfortable using the curriculum in the classroom," $1 \%(f=1)$ strongly disagreed, $2 \%(f=4)$ somewhat disagreed, $12 \%(f=22)$ somewhat agreed, $45 \%(f=85)$ agreed and $41 \%(f=79)$ strongly agreed (see Table 22$)$. When given the statement, "my knowledge and skills of the material increased from the training," $1 \%(f=1)$ strongly disagreed, $1 \%(f=1)$ disagreed, 3\% $(f=5)$ somewhat disagreed, $17 \%(f=32)$ somewhat agreed, $37 \%(f=71)$ agreed, and $42 \%(f=81)$ strongly agreed. When given the statement, "the training led to a positive change in their instruction," $1 \%(f=1)$ strongly disagreed, $3 \%(f=6)$ somewhat disagreed, $10 \%(f=18)$ somewhat agreed, $40 \%(f=77)$ agreed, $47 \%(f=89)$ strongly agreed. When given the statement concerning their students improve learning, $1 \%(f=1)$ strongly disagreed, $1 \%$ $(f=2)$ disagreed, $4 \%(f=8)$ somewhat disagreed, $14 \%(f=26)$ somewhat agreed, $42 \%(f$ $=81)$ agreed, $38 \%(f=73)$ strongly agreed. 
Table 22

Post CASE Training ${ }^{a}$

\begin{tabular}{|c|c|c|c|c|c|c|c|c|c|c|c|c|}
\hline & \multicolumn{2}{|c|}{$\begin{array}{l}\text { Strongly } \\
\text { Disagree }\end{array}$} & \multicolumn{2}{|c|}{ Disagree } & \multicolumn{2}{|c|}{$\begin{array}{l}\text { Somewhat } \\
\text { Disagree }\end{array}$} & \multicolumn{2}{|c|}{ Somewhat Agree } & \multicolumn{2}{|c|}{ Agree } & \multicolumn{2}{|c|}{ Strongly Agree } \\
\hline & $f$ & $\%$ & $f$ & $\%$ & $f$ & $\%$ & $f$ & $\%$ & $f$ & $\%$ & $f$ & $\%$ \\
\hline $\begin{array}{l}\text { I was comfortable } \\
\text { using the curriculum } \\
\text { in the classroom. }\end{array}$ & 1 & .52 & 0 & .00 & 4 & 2.09 & 22 & 11.52 & 85 & 44.50 & 79 & 41.36 \\
\hline $\begin{array}{l}\text { My knowledge and } \\
\text { skills of the material } \\
\text { increased from the } \\
\text { training. }\end{array}$ & 1 & .52 & 1 & .52 & 5 & 2.62 & 32 & 16.75 & 71 & 37.17 & 81 & 42.41 \\
\hline $\begin{array}{l}\text { The training led to a } \\
\text { positive change in } \\
\text { my instruction. }\end{array}$ & 1 & .52 & 0 & .00 & 6 & 3.14 & 18 & 9.42 & 77 & 40.31 & 89 & 46.60 \\
\hline $\begin{array}{l}\text { My students learning } \\
\text { improved. }\end{array}$ & 1 & .52 & 2 & 1.05 & 8 & 4.19 & 26 & 13.61 & 81 & 42.41 & 73 & 38.22 \\
\hline
\end{tabular}

Note: ${ }^{\mathrm{a}}(n=191)$ 
Respondents were asked the extent to which they agreed or disagreed with statements concerning the CASE ASA lesson plans. When given the statement," The ASA course CASE lesson plans are user friendly to anyone who tries to use them," $3 \%$ ( $f$ $=5)$ somewhat disagreed, $19 \%(f=38)$ somewhat agreed, $49 \%(f=94)$ agreed, and $28 \%$ $(f=54)$ strongly agreed (see Table 23$)$. When given the statement, "The ASA course CASE lesson plans \& contain the material to be taught in each lesson," $1 \%(f=1)$ strongly disagreed, $2 \%(f=3)$ disagreed, $3 \%(f=6)$ somewhat disagreed, $13 \%(f=25)$ somewhat agreed, $41 \%(f=79)$ agreed, and 40\% $(f=77)$ strongly agreed. When given the statement, "The ASA course CASE lesson plans contain the material to be taught in each unit," $1 \%(f=1)$ strongly disagreed, $3 \%(f=5)$ disagreed, $3 \%(f=6)$ somewhat disagreed, $11 \%(f=20)$ somewhat agreed, $46 \%(f=87)$ agreed, and $38 \%(f=72)$ strongly agreed. When given the statement, "The ASA course CASE lesson plans overall contain the needed amount of material," $1 \%(f=1)$ strongly disagreed, 3\% $(f=5)$ disagreed, 4\% $(f=7)$ somewhat disagreed, $12 \%(f=23)$ somewhat agreed, $48 \%(f=91)$ agreed, and $33 \%(f=63)$ strongly agreed. 
Table 23

\section{CASE ASA Lesson Plans}

\begin{tabular}{|c|c|c|c|c|c|c|c|c|c|c|c|c|c|}
\hline & \multicolumn{2}{|c|}{$\begin{array}{l}\text { Strongly } \\
\text { Disagree }\end{array}$} & \multicolumn{2}{|c|}{ Disagree } & \multicolumn{2}{|c|}{$\begin{array}{l}\text { Somewhat } \\
\text { Disagree }\end{array}$} & \multicolumn{2}{|c|}{$\begin{array}{l}\text { Somewhat } \\
\text { Agree }\end{array}$} & \multicolumn{2}{|c|}{ Agree } & \multicolumn{2}{|c|}{ Strongly Agree } & \multirow[b]{2}{*}{$n$} \\
\hline & $f$ & $\%$ & $f$ & $\%$ & $f$ & $\%$ & $f$ & $\%$ & $f$ & $\%$ & $f$ & $\%$ & \\
\hline $\begin{array}{l}\text { Plans are user } \\
\text { friendly to anyone } \\
\text { who tries to use } \\
\text { them. }\end{array}$ & 0 & .00 & 0 & .00 & 5 & 2.62 & 38 & 19.90 & 94 & 49.21 & 54 & 28.27 & 191 \\
\hline $\begin{array}{l}\text { Plans contain the } \\
\text { material to be } \\
\text { taught in each }\end{array}$ & & & & & & & & & & & & & \\
\hline lesson. & 1 & .52 & 3 & 1.57 & 6 & 3.14 & 25 & 13.09 & 79 & 41.36 & 77 & 40.31 & 191 \\
\hline $\begin{array}{l}\text { Plans contain the } \\
\text { material to be } \\
\text { taught in each unit. }\end{array}$ & 1 & .52 & 5 & 2.62 & 6 & 3.14 & 20 & 10.47 & 87 & 45.55 & 72 & 37.70 & 191 \\
\hline $\begin{array}{l}\text { Plans overall } \\
\text { contain the needed } \\
\text { amount of material. }\end{array}$ & 1 & .53 & 5 & 2.63 & 7 & 3.68 & 23 & 12.11 & 91 & 47.89 & 63 & 33.16 & 190 \\
\hline
\end{tabular}


Respondents were asked to what degree they agreed or disagreed with the incorporation of FFA and leadership aspects in the CASE curriculum as opposed to previous curriculums. For classroom and laboratory, $13 \%(f=24)$ agreed that its incorporation was equal to previous curriculums, $51 \%(f=98)$ agreed that its incorporation was superior and 35\% $(f=66)$ agreed that its incorporation was definitely superior (see Table 24). Of those responding, $1 \%(f=1)$ thought CASE's incorporation of classroom and laboratory was definitely inferior and $1 \%(f=2)$ thought it was inferior compared to previous curriculums. For FFA and leadership incorporation, 5\% $(f=10)$ agreed that CASE's incorporation was definitely inferior, $27 \%(f=52)$ agreed that it was inferior, $45 \%(f=86)$ agreed that it was equal to, $16 \%(f=30)$ agreed that it was superior, and $6 \%(f=12)$ agreed that it was definitely superior. For Supervised Agriculture Experience (SAE), 5\% $(f=10)$ agreed that CASE's incorporation was definitely inferior, $23 \%(f=43)$ agreed that the incorporation was inferior, $48 \%(f=91)$ agreed that it was equal to, $18 \%(f=33)$ agreed that it was superior, and $6 \%(f=12)$ agreed that it was definitely superior. Concerning CASE's incorporation of all aspects of an Agricultural education Program, 2\% $(f=4)$ agreed that its incorporation was definitely inferior, $4 \%(f$ $=8)$ agreed that it was inferior, 35\% $(f=67)$ agreed it was equal to, $46 \%(f=87)$ agreed that it was superior, and $13 \%(f=24)$ agreed that it was definitely superior. 
Table 24

CASE Incorporation of Parts of the Agricultural Education Model

\begin{tabular}{|c|c|c|c|c|c|c|c|c|c|c|c|}
\hline & \multicolumn{2}{|c|}{ Definitely Inferior } & \multicolumn{2}{|c|}{ Inferior } & \multicolumn{2}{|c|}{ Equal To } & \multicolumn{2}{|c|}{ Superior } & \multicolumn{2}{|c|}{$\begin{array}{l}\text { Definitely } \\
\text { Superior }\end{array}$} & \multirow[b]{2}{*}{$n$} \\
\hline & $f$ & $\%$ & $f$ & $\%$ & $f$ & $\%$ & $f$ & $\%$ & $f$ & $\%$ & \\
\hline $\begin{array}{l}\text { Classroom and } \\
\text { laboratory }\end{array}$ & 1 & .52 & 2 & 1.05 & 24 & 12.57 & 98 & 51.31 & 66 & 34.55 & 191 \\
\hline FFA and leadership & 10 & 5.26 & 52 & 27.37 & 86 & 45.26 & 30 & 15.79 & 12 & 6.32 & 190 \\
\hline $\begin{array}{l}\text { Supervised Agriculture } \\
\text { Experiences (SAE) }\end{array}$ & 10 & 5.29 & 43 & 22.75 & 91 & 48.15 & 33 & 17.46 & 12 & 6.35 & 189 \\
\hline $\begin{array}{l}\text { All aspects of an } \\
\text { Agricultural education } \\
\text { Program }\end{array}$ & 4 & 2.11 & 8 & 4.21 & 67 & 35.26 & 87 & 45.79 & 24 & 12.63 & 190 \\
\hline
\end{tabular}


Respondents were asked the degree to which they agreed or disagreed with statements concerning their student's perceptions of the CASE curriculum ASA course. When given the statement, "Students enjoyed the creativity of the ASA course lessons," $2 \%(f=3)$ strongly disagreed, $1 \%(f=1)$ disagreed, $3 \%(f=6)$ somewhat disagreed, $27 \%$ $(f=52)$ somewhat agreed, $43 \%(f=81)$ agreed, and 25\% $(f=47)$ strongly agreed (see Table 25). When given the statement, "Students enjoyed the spontaneity of the AFNR course lessons," $2 \%(f=3)$ strongly disagreed, $9 \%(f=16)$ somewhat disagreed, $29 \%(f=$ 56) somewhat agreed, 44\% $(f=33)$ agreed, $17 \%(f=33)$ strongly agreed. When given the statement, "Students enjoyed the AFNR course," $1 \%(f=2)$ strongly disagreed, $1 \%(f$ $=1)$ disagreed, $4 \%(f=7)$ somewhat disagreed, $21 \%(f=40)$ somewhat agreed, $49 \%(f=$ 94) agreed, and $25 \%(f=47)$ strongly agreed. 
Table 25

Student Perceptions of CASE Creativity as Perceived by Their Teachers

\begin{tabular}{|c|c|c|c|c|c|c|c|c|c|c|c|c|c|}
\hline & \multicolumn{2}{|c|}{$\begin{array}{l}\text { Strongly } \\
\text { Disagree }\end{array}$} & \multicolumn{2}{|c|}{ Disagree } & \multicolumn{2}{|c|}{$\begin{array}{l}\text { Somewhat } \\
\text { Disagree }\end{array}$} & \multicolumn{2}{|c|}{$\begin{array}{l}\text { Somewhat } \\
\text { Agree }\end{array}$} & \multicolumn{2}{|c|}{ Agree } & \multicolumn{2}{|c|}{ Strongly Agree } & \multirow[b]{2}{*}{$n$} \\
\hline & $f$ & $\%$ & $f$ & $\%$ & $f$ & $\%$ & $f$ & $\%$ & $f$ & $\%$ & $f$ & $\%$ & \\
\hline $\begin{array}{l}\text { Students enjoyed } \\
\text { the creativity of th } \\
\text { ASA course } \\
\text { lessons. }\end{array}$ & 3 & 1.58 & 1 & .53 & 6 & 3.16 & 52 & 27.37 & 81 & 42.63 & 47 & 24.74 & 190 \\
\hline $\begin{array}{l}\text { Students enjoyed } \\
\text { the spontaneity of } \\
\text { the ASA course } \\
\text { lessons. }\end{array}$ & 3 & 1.57 & 0 & .00 & 16 & 8.38 & 56 & 29.32 & 83 & 43.46 & 33 & 17.28 & 191 \\
\hline $\begin{array}{l}\text { Students enjoyed } \\
\text { the ASA course. }\end{array}$ & 2 & 1.05 & 1 & .52 & 7 & 3.66 & 40 & 20.94 & 94 & 49.21 & 47 & 24.61 & 191 \\
\hline
\end{tabular}


Respondents were asked to select a number from 1-100 to represent the level of student's positive excitement over time for the CASE curriculum ASA course. For student's positive level of excitement of the beginning of the course, the mean was 61.97 and the standard deviation was 23.62 (see Table 26). For student's positive excitement in the middle of the course, the mean was 69.08 with the standard deviation of 17.12 . For student's positive excitement at the end of the course, the mean was 76.40 and the standard deviation was 19.70 .

Table 26

Students' Levels of Positive Excitement

M SD

Students' positive excitement at the beginning of the course.

Students' positive excitement in the middle of the course.

Students' positive excitement at the end of the course.

\section{Principles of Agricultural Science- Plant (ASP)}

Respondents were asked about the training for the Principles of Agricultural Science- Plant course. When asked about their feelings that the training prepared them to implement the course, $6 \%(f=10)$ somewhat agreed, $41 \%(f=69)$ agreed, and $51 \%$ of the respondents $(f=83)$ strongly agreed (see Table 27). Respondents were asked the degree to which they agreed and disagreed for the trainings preparation to use the lesson 
plans in the classroom. Of those who responded, $10 \%(f=16)$ somewhat agreed, $36 \%(f=$ $59)$ agreed, and $54 \%(f=88)$ strongly agreed. Respondents were asked the degree to which they agreed or disagreed that the training prepared them to use the course Power Points in the classroom. Of the respondents, $2 \%(f=3)$ disagreed, $1 \%(f=1)$ somewhat disagreed. $12 \%(f=20)$ somewhat agreed, 29\% $(f=64)$ agreed, and $46 \%(f=75)$ strongly agreed. 
Table 27

CASE Training Prepared Individuals to:

\begin{tabular}{|c|c|c|c|c|c|c|c|c|c|c|c|c|c|}
\hline & \multicolumn{2}{|c|}{$\begin{array}{l}\text { Strongly } \\
\text { Disagree }\end{array}$} & \multicolumn{2}{|c|}{ Disagree } & \multicolumn{2}{|c|}{$\begin{array}{l}\text { Somewhat } \\
\text { Disagree }\end{array}$} & \multicolumn{2}{|c|}{$\begin{array}{c}\text { Somewhat } \\
\text { Agree }\end{array}$} & \multicolumn{2}{|c|}{ Agree } & \multicolumn{2}{|c|}{ Strongly Agree } & \multirow[b]{2}{*}{$n$} \\
\hline & $f$ & $\%$ & $f$ & $\%$ & $f$ & $\%$ & $f$ & $\%$ & $f$ & $\%$ & $f$ & $\%$ & \\
\hline Implement the ASP & & & & & & & & & & & & & \\
\hline CASE course & 0 & .00 & 0 & .00 & 0 & .00 & 10 & 6.17 & 69 & 42.59 & 83 & 51.23 & 162 \\
\hline $\begin{array}{l}\text { Use the CASE } \\
\text { curriculum ASP } \\
\text { course lesson plans }\end{array}$ & 0 & .00 & 0 & .00 & 0 & .00 & 16 & 9.82 & 59 & 36.20 & 88 & 53.99 & 163 \\
\hline $\begin{array}{l}\text { Use the ASP course } \\
\text { CASE Power } \\
\text { Points included in } \\
\text { the curriculum }\end{array}$ & 0 & .00 & 3 & 1.84 & 1 & .61 & 20 & 12.27 & 64 & 39.26 & 75 & 46.01 & 163 \\
\hline
\end{tabular}


Respondents were asked if they required assistance from CASE support staff in implementing the CASE course ASP in their classroom. Of those responding, $26 \%(f=$ 42) required assistance, $74 \%(f=120)$ did not (see Table 28$)$.

Table 28

Respondents Who Required Assistance from CASE When Implementing the Course in a Classroom $^{a}$

\begin{tabular}{lcc}
\hline & $f$ & $\%$ \\
\hline Yes & 42 & 25.93 \\
No & 120 & 74.07 \\
\hline
\end{tabular}

Note: ${ }^{\mathrm{a}}(n=162)$

The respondents who required assistance from CASE support staff when implementing the ASP course were given statements, and asked the extent to which they agreed or disagreed. When given the statement "I received assistance from a CASE staff member or lead teacher when implementing the CASE curriculum," $5 \%(f=2)$ strongly disagreed, $7 \%(f=3)$ disagreed, 12\% $(f=5)$ somewhat agreed, 43\% (f=18) agreed, and $33 \%(f=14)$ strongly agreed (see Table 29$)$. When given the statement, "The professional development was helpful for problems that arose over time using the curriculum," $3 \%(f=1)$ strongly disagreed, $5 \%(f=2)$ somewhat disagreed, $12 \%(f=5)$ somewhat agreed, $38 \%(f=16)$ agreed, and $43 \%(f=18)$ strongly agreed. When given the statement "The professional development aspect involved interactions through the National Association of Agricultural Educators Community of Practice Forum," $5 \%$ ( $f=$ 2) disagreed, $2 \%(f=1)$ somewhat disagreed, $5 \%(f=2)$ somewhat agreed, $42 \%(f=17)$ agreed, and $46 \%(f=19)$ strongly agreed. 
Table 29

Aspects of Post CASE Training Assistance

\begin{tabular}{|c|c|c|c|c|c|c|c|c|c|c|c|c|c|}
\hline & \multicolumn{2}{|c|}{$\begin{array}{l}\text { Strongly } \\
\text { Disagree }\end{array}$} & \multicolumn{2}{|c|}{ Disagree } & \multicolumn{2}{|c|}{$\begin{array}{l}\text { Somewhat } \\
\text { Disagree }\end{array}$} & \multicolumn{2}{|c|}{$\begin{array}{c}\text { Somewhat } \\
\text { Agree }\end{array}$} & \multicolumn{2}{|c|}{ Agree } & \multicolumn{2}{|c|}{ Strongly Agree } & \multirow[b]{2}{*}{$n$} \\
\hline & $f$ & $\%$ & $f$ & $\%$ & $f$ & $\%$ & $f$ & $\%$ & $f$ & $\%$ & $f$ & $\%$ & \\
\hline $\begin{array}{l}\text { Received assistance } \\
\text { from a CASE staff } \\
\text { member or lead } \\
\text { teacher }\end{array}$ & 2 & 4.76 & 3 & 7.14 & 0 & .00 & 5 & 11.90 & 18 & 42.86 & 14 & 33.33 & 42 \\
\hline $\begin{array}{l}\text { Helpful for } \\
\text { problems that arose } \\
\text { over time using the } \\
\text { curriculum }\end{array}$ & 1 & 2.38 & 0 & .00 & 2 & 4.76 & 5 & 11.90 & 16 & 38.10 & 18 & 42.86 & 42 \\
\hline $\begin{array}{l}\text { Interactions through } \\
\text { the National } \\
\text { Association of } \\
\text { Agricultural } \\
\text { Educators } \\
\text { Community of } \\
\text { Practice Forum }\end{array}$ & 0 & .00 & 2 & 4.88 & 1 & 2.44 & 2 & 4.88 & 17 & 41.46 & 19 & 46.34 & 41 \\
\hline
\end{tabular}


Respondents were asked how they felt in their classrooms after the CASE training. When given the statement, "I was comfortable using the curriculum in the classroom," 2\% $(f=3)$ somewhat disagreed, $16 \%(f=26)$ somewhat agreed, $46 \%(f=74)$ agreed and $36 \%(f=57)$ strongly agreed (see Table 30$)$. When given the statement, "my knowledge and skills of the material increased from the training," $1 \%(f=1)$ strongly disagreed, $1 \%(f=1)$ disagreed, 3\% $(f=4)$ somewhat disagreed, $9 \%(f=14)$ somewhat agreed, $40 \%(f=64)$ agreed, and $48 \%(f=77)$ strongly agreed. When given the statement, "the training led to a positive change in their instruction," $1 \%(f=1)$ strongly disagreed, $1 \%(f=1)$ disagreed, $1 \%(f=1)$ somewhat disagreed, $13 \%(f=20)$ somewhat agreed, 36\% $(f=58)$ agreed, $48 \%(f=76)$ strongly agreed. When given the statement concerning their students improve learning, $1 \%(f=1)$ strongly disagreed, $1 \%(f=2)$ disagreed, $1 \%(f=1)$ somewhat disagreed, $18 \%(f=28)$ somewhat agreed, $37 \%(f=58)$ agreed, $43 \%(f=69)$ strongly agreed. 
Table 30

\section{Post CASE Training}

\begin{tabular}{|c|c|c|c|c|c|c|c|c|c|c|c|c|c|}
\hline & \multicolumn{2}{|c|}{$\begin{array}{l}\text { Strongly } \\
\text { Disagree }\end{array}$} & \multicolumn{2}{|c|}{ Disagree } & \multicolumn{2}{|c|}{$\begin{array}{l}\text { Somewhat } \\
\text { Disagree }\end{array}$} & \multicolumn{2}{|c|}{$\begin{array}{l}\text { Somewhat } \\
\text { Agree }\end{array}$} & \multicolumn{2}{|c|}{ Agree } & \multicolumn{2}{|c|}{ Strongly Agree } & \multirow[b]{2}{*}{$n$} \\
\hline & $f$ & $\%$ & $f$ & $\%$ & $f$ & $\%$ & $f$ & $\%$ & $f$ & $\%$ & $f$ & $\%$ & \\
\hline $\begin{array}{l}\text { I was comfortable } \\
\text { using the } \\
\text { curriculum in the } \\
\text { classroom. }\end{array}$ & 0 & .00 & 0 & .00 & 3 & 1.88 & 26 & 16.25 & 74 & 46.25 & 57 & 35.63 & 160 \\
\hline $\begin{array}{l}\text { My knowledge and } \\
\text { skills of the } \\
\text { material increased } \\
\text { from the training. }\end{array}$ & 1 & .63 & 0 & .00 & 4 & 2.50 & 14 & 8.75 & 64 & 40.00 & 77 & 48.13 & 160 \\
\hline $\begin{array}{l}\text { The training led to } \\
\text { a positive change in } \\
\text { my instruction. }\end{array}$ & 1 & .63 & 1 & .63 & 4 & 2.50 & 20 & 12.50 & 58 & 36.25 & 76 & 47.50 & 160 \\
\hline $\begin{array}{l}\text { My students } \\
\text { learning improved. }\end{array}$ & 1 & .63 & 2 & 1.26 & 1 & .63 & 28 & 17.61 & 58 & 36.48 & 69 & 43.40 & 159 \\
\hline
\end{tabular}


Respondents were asked the extent to which they agreed or disagreed with statements concerning the CASE ASP lesson plans. When given the statement," The ASP course CASE lesson plans are user friendly to anyone who tries to use them," $4 \%(f=6)$ somewhat disagreed, $21 \%(f=33)$ somewhat agreed, $44 \%(f=70)$ agreed, $31 \%(f=49)$ strongly agreed (see Table 31). When given the statement, "The ASP course CASE lesson plans \& contain the material to be taught in each lesson," 3\% $(f=4)$ disagreed, 3\% $(f=5)$ somewhat disagreed, $8 \%(f=13)$ somewhat agreed, $50 \%(f=78)$ agreed, and $36 \%$ $(f=57)$ strongly agreed. When given the statement, "The ASP course CASE lesson plans contain the material to be taught in each unit," $3 \%(f=5)$ disagreed, $2 \%(f=3)$ somewhat disagreed, $11 \%(f=17)$ somewhat agreed, $46 \%(f=72)$ agreed, and $39 \%(f=61)$ strongly agreed. When given the statement, "The ASP course CASE lesson plans overall contain the needed amount of material," $2 \%(f=3)$ disagreed, $4 \%(f=6)$ disagreed, $15 \%(f=23)$ somewhat agreed, 44\% $(f=70)$ agreed, and 35\% $(f=56)$ strongly agreed. 
Table 31

\section{CASE ASP Lesson Plans}

\begin{tabular}{|c|c|c|c|c|c|c|c|c|c|c|c|c|c|}
\hline & \multicolumn{2}{|c|}{$\begin{array}{l}\text { Strongly } \\
\text { Disagree }\end{array}$} & \multicolumn{2}{|c|}{ Disagree } & \multicolumn{2}{|c|}{$\begin{array}{l}\text { Somewhat } \\
\text { Disagree }\end{array}$} & \multicolumn{2}{|c|}{$\begin{array}{l}\text { Somewhat } \\
\text { Agree }\end{array}$} & \multicolumn{2}{|c|}{ Agree } & \multicolumn{2}{|c|}{ Strongly Agree } & \multirow[b]{2}{*}{$n$} \\
\hline & $f$ & $\%$ & $f$ & $\%$ & $f$ & $\%$ & $f$ & $\%$ & $f$ & $\%$ & $f$ & $\%$ & \\
\hline $\begin{array}{l}\text { Plans are user } \\
\text { friendly to anyone } \\
\text { who tries to use } \\
\text { them. }\end{array}$ & 0 & .00 & 0 & .00 & 6 & 3.80 & 33 & 20.89 & 70 & 44.30 & 49 & 31.01 & 158 \\
\hline $\begin{array}{l}\text { Plans \& contain the } \\
\text { material to be } \\
\text { taught in each }\end{array}$ & & & & & & & & & & & & & \\
\hline lesson. & 0 & .00 & 4 & 2.55 & 5 & 3.18 & 13 & 8.28 & 78 & 49.68 & 57 & 36.31 & 157 \\
\hline $\begin{array}{l}\text { Plans contain the } \\
\text { material to be } \\
\text { taught in each unit. }\end{array}$ & 0 & .00 & 5 & 3.16 & 3 & 1.90 & 17 & 10.76 & 72 & 45.57 & 61 & 38.61 & 158 \\
\hline $\begin{array}{l}\text { Plans overall } \\
\text { contain the needed } \\
\text { amount of material. }\end{array}$ & 0 & .00 & 3 & 1.90 & 6 & 3.80 & 23 & 14.56 & 70 & 44.30 & 56 & 35.44 & 158 \\
\hline
\end{tabular}


Respondents were asked to what degree they agreed or disagreed with the incorporation of FFA and leadership aspects in the CASE curriculum as opposed to previous curriculums. For classroom and laboratory, $1 \%(f=2)$ agreed it was definitely inferior, $1 \%(f=2)$ agreed it was inferior, and $11 \%(f=17)$ agreed it was equal to, $40 \%(f$ $=63)$ agreed it was superior and $47 \%(f=74)$ agreed that its incorporation was definitely superior (see Table 32). For FFA and leadership incorporation, 5\% $(f=8)$ agreed that CASE's incorporation was definitely inferior, $24 \%(f=38)$ agreed that it was inferior, $51 \%(f=79)$ agreed that it was equal to, $13 \%(f=20)$ agreed that it was superior, and $7 \%$ $(f=11)$ agreed that it was definitely superior. For Supervised Agriculture Experience (SAE), 5\% $(f=7)$ agreed that CASE's incorporation was definitely inferior, $22 \%(f=34)$ agreed that the incorporation was inferior, $47 \%(f=74)$ agreed that it was equal to, $18 \%$ $(f=28)$ agreed that it was superior, and $9 \%(f=14)$ agreed that it was definitely superior. Concerning CASE's incorporation of all aspects of an Agricultural education Program, $3 \%(f=4)$ agreed that its incorporation was definitely inferior, $6 \%(f=9)$ agreed that it was inferior, $33 \%(f=52)$ agreed it was equal to, $43 \%(f=67)$ agreed that it was superior, and $16 \%(f=25)$ agreed that it was definitely superior. 
Table 32

CASE Incorporation of Parts of the Agricultural Education Model

\begin{tabular}{|c|c|c|c|c|c|c|c|c|c|c|c|}
\hline & \multicolumn{2}{|c|}{ Definitely Inferior } & \multicolumn{2}{|c|}{ Inferior } & \multicolumn{2}{|c|}{ Equal To } & \multicolumn{2}{|c|}{ Superior } & \multicolumn{2}{|c|}{$\begin{array}{l}\text { Definitely } \\
\text { Superior }\end{array}$} & \multirow[b]{2}{*}{$n$} \\
\hline & $f$ & $\%$ & $f$ & $\%$ & $f$ & $\%$ & $f$ & $\%$ & $f$ & $\%$ & \\
\hline $\begin{array}{l}\text { Classroom and } \\
\text { laboratory }\end{array}$ & 2 & 1.27 & 2 & 1.27 & 17 & 10.76 & 63 & 39.87 & 74 & 46.84 & 158 \\
\hline FFA and leadership & 8 & 5.13 & 38 & 24.36 & 79 & 50.64 & 20 & 12.82 & 11 & 7.05 & 156 \\
\hline $\begin{array}{l}\text { Supervised Agriculture } \\
\text { Experiences (SAE) }\end{array}$ & 7 & 4.46 & 34 & 21.66 & 74 & 47.13 & 28 & 17.83 & 14 & 8.92 & 157 \\
\hline $\begin{array}{l}\text { All aspects of an } \\
\text { Agricultural education } \\
\text { Program }\end{array}$ & 4 & 2.55 & 9 & 5.73 & 52 & 33.12 & 67 & 42.68 & 25 & 15.92 & 157 \\
\hline
\end{tabular}


Respondents were asked the degree to which they agreed or disagreed with statements concerning their student's perceptions of the CASE curriculum ASP course. When given the statement, "Students enjoyed the creativity of the ASP course lessons," $1 \%(f=2)$ strongly disagreed, $1 \%(f=2)$ disagreed, $3 \%(f=4)$ somewhat disagreed, $23 \%$ $(f=37)$ somewhat agreed, $49 \%(f=77)$ agreed, and 23\% $(f=36)$ strongly agreed (see Table 33). When given the statement, "Students enjoyed the spontaneity of the ASP course lessons," $1 \%(f=2)$ strongly disagreed, $3 \%(f=4)$ disagreed, $8 \%(f=13)$ somewhat disagreed, $25 \%(f=39)$ somewhat agreed, $41 \%(f=65)$ agreed, $21 \%(f=36)$ strongly agreed. When given the statement, "Students enjoyed the ASP course," $1 \%(f=$ 2) strongly disagreed, $1 \%(f=1)$ disagreed, $3 \%(f=4)$ somewhat disagreed, $20 \%(f=32)$ somewhat agreed, $49 \%(f=78)$ agreed, and 26\% $(f=42)$ strongly agreed. 
Table 33

Student Perceptions of Case Creativity as Perceived by Their Teachers

\begin{tabular}{|c|c|c|c|c|c|c|c|c|c|c|c|c|c|}
\hline & \multicolumn{2}{|c|}{$\begin{array}{l}\text { Strongly } \\
\text { Disagree }\end{array}$} & \multicolumn{2}{|c|}{ Disagree } & \multicolumn{2}{|c|}{$\begin{array}{l}\text { Somewhat } \\
\text { Disagree }\end{array}$} & \multicolumn{2}{|c|}{$\begin{array}{c}\text { Somewhat } \\
\text { Agree }\end{array}$} & \multicolumn{2}{|c|}{ Agree } & \multicolumn{2}{|c|}{ Strongly Agree } & \multirow[b]{2}{*}{$n$} \\
\hline & $f$ & $\%$ & $f$ & $\%$ & $f$ & $\%$ & $f$ & $\%$ & $f$ & $\%$ & $f$ & $\%$ & \\
\hline $\begin{array}{l}\text { Students enjoyed } \\
\text { the creativity of the } \\
\text { ASP course lessons. }\end{array}$ & 2 & 1.27 & 2 & 1.27 & 4 & 2.53 & 37 & 23.42 & 77 & 48.73 & 36 & 22.78 & 158 \\
\hline $\begin{array}{l}\text { Students enjoyed } \\
\text { the spontaneity of } \\
\text { the ASP course } \\
\text { lessons. }\end{array}$ & 2 & 1.26 & 4 & 2.52 & 13 & 8.18 & 39 & 24.53 & 65 & 40.88 & 36 & 22.64 & 159 \\
\hline $\begin{array}{l}\text { Students enjoyed } \\
\text { the ASP course. }\end{array}$ & 2 & 1.26 & 1 & .63 & 4 & 2.52 & 32 & 20.13 & 78 & 49.06 & 42 & 26.42 & 159 \\
\hline
\end{tabular}


Respondents were asked to select a number from 1-100 to represent the level of student's positive excitement over time for the CASE curriculum ASP course. For student's positive level of excitement of the beginning of the course, the mean was 56.53 and the standard deviation was 24.90 (see Table 24). For student's positive excitement in the middle of the course, the mean was 65.55 with the standard deviation of 18.76 . For student's positive excitement at the end of the course, the mean was 73.54 and the standard deviation was 21.19.

Table 34

Students' Levels of Positive Excitement Over Time

M SD

Students' positive excitement at the beginning of the course.

56.53

Students' positive excitement in the middle of the course.

Students' positive excitement at the end of the course.

Average

65.21 


\section{Agricultural Power and Technology (APT)}

Respondents were asked about the training for the Agricultural Power and Technology course. When asked about their feelings towards the training and if they felt it prepared them to implement the course, $16 \%(f=3)$ somewhat agreed, $21 \%(f=4)$ agreed, and $63 \%$ of the respondents $(f=12)$ strongly agreed (see Table 35). Respondents were asked the degree to which they agreed and disagreed that the training prepared them to use the lesson plans in the classroom. Of those who responded, $21 \%(f=4)$ somewhat agreed, 26\% $(f=5)$ agreed, and 53\% $(f=10)$ strongly agreed. Respondents were asked the degree to which they agreed or disagreed that the training prepared them to use the course Power Points in the classroom. Of the respondents, $16 \%(f=3)$ somewhat agreed, $21 \%(f=4)$ agreed, and $63 \%(f=12)$ strongly agreed. 
Table 35

CASE Training Prepared Individuals to: ${ }^{a}$

\begin{tabular}{|c|c|c|c|c|c|c|c|c|c|c|c|c|}
\hline & \multicolumn{2}{|c|}{$\begin{array}{l}\text { Strongly } \\
\text { Disagree }\end{array}$} & \multicolumn{2}{|c|}{ Disagree } & \multicolumn{2}{|c|}{$\begin{array}{l}\text { Somewhat } \\
\text { Disagree }\end{array}$} & \multicolumn{2}{|c|}{ Somewhat Agree } & \multicolumn{2}{|c|}{ Agree } & \multicolumn{2}{|c|}{ Strongly Agree } \\
\hline & $f$ & $\%$ & $f$ & $\%$ & $f$ & $\%$ & $f$ & $\%$ & $f$ & $\%$ & $f$ & $\%$ \\
\hline Implement the APT & & & & & & & & & & & & \\
\hline CASE course & 0 & .00 & 0 & .00 & 0 & .00 & 3 & 15.79 & 4 & 21.05 & 12 & 63.16 \\
\hline $\begin{array}{l}\text { Use the CASE } \\
\text { curriculum APT } \\
\text { course lesson plans }\end{array}$ & 0 & .00 & 0 & .00 & 0 & .00 & 4 & 21.05 & 5 & 26.32 & 10 & 52.63 \\
\hline $\begin{array}{l}\text { Use the APT course } \\
\text { CASE Power Points } \\
\text { included in the } \\
\text { curriculum }\end{array}$ & 0 & .00 & 0 & .00 & 0 & .00 & 3 & 15.79 & 4 & 21.05 & 12 & 63.16 \\
\hline
\end{tabular}


Respondents were asked if they required assistance from CASE support staff in implementing the CASE course APT in their classroom. Of those responding, $5 \%(f=1)$ required assistance, $95 \%(f=18)$ did not (see Table 36$)$.

Table 36

Respondents Who Required Assistance from CASE When Implementing the Course in a Classroom $^{a}$

\begin{tabular}{lcc}
\hline & $f$ & $\%$ \\
\hline Yes & 1 & 5.26 \\
No & 18 & 94.74 \\
\hline
\end{tabular}

Note: ${ }^{\mathrm{a}}(n=19)$

The respondents who required assistance from CASE support staff when implementing the APT course were given statements, and asked the extent to which they agreed or disagreed. When given the statement "I received assistance from a CASE staff member or lead teacher when implementing the CASE curriculum,"100\% $(f=1)$ strongly disagreed (see Table 37). When given the statement, "The professional development was helpful for problems that arose over time using the curriculum," $100 \%(f=1)$ strongly agreed. When given the statement "The professional development aspect involved interactions through the National Association of Agricultural Educators Community of Practice Forum," $100 \%(f=1)$ strongly agreed. 
Table 37

Aspects of Post CASE Training Assistance ${ }^{a}$

\begin{tabular}{|c|c|c|c|c|c|c|c|c|c|c|c|c|}
\hline & \multicolumn{2}{|c|}{$\begin{array}{l}\text { Strongly } \\
\text { Disagree }\end{array}$} & \multicolumn{2}{|c|}{ Disagree } & \multicolumn{2}{|c|}{$\begin{array}{l}\text { Somewhat } \\
\text { Disagree }\end{array}$} & \multicolumn{2}{|c|}{ Somewhat Agree } & \multicolumn{2}{|c|}{ Agree } & \multicolumn{2}{|c|}{ Strongly Agree } \\
\hline & $f$ & $\%$ & $f$ & $\%$ & $f$ & $\%$ & $f$ & $\%$ & $f$ & $\%$ & $f$ & $\%$ \\
\hline $\begin{array}{l}\text { Received assistance } \\
\text { from a CASE staff } \\
\text { member or lead } \\
\text { teacher }\end{array}$ & 1 & 100.00 & 0 & .00 & 0 & .00 & 0 & .00 & 0 & .00 & 0 & .00 \\
\hline $\begin{array}{l}\text { Helpful for problems } \\
\text { that arose over time } \\
\text { using the curriculum }\end{array}$ & 0 & .00 & 0 & .00 & 0 & .00 & 0 & .00 & 0 & .00 & 1 & 100.00 \\
\hline $\begin{array}{l}\text { Interactions through } \\
\text { the National } \\
\text { Association of } \\
\text { Agricultural } \\
\text { Educators } \\
\text { Community of } \\
\text { Practice Forum }\end{array}$ & 0 & .00 & 0 & .00 & 0 & .00 & 0 & .00 & 0 & .00 & 1 & 100.00 \\
\hline
\end{tabular}

Note: ${ }^{\text {a }}(n=1)$ 
Respondents were asked how they felt in their classrooms after the CASE training. When given the statement, "I was comfortable using the curriculum in the classroom," 26\% (f= 5) somewhat agreed, 16\% (f=3) agreed and 58\% (f=11) strongly agreed (see Table 38). When given the statement, "my knowledge and skills of the material increased from the training," $5 \%(f=1)$ somewhat disagreed, $16 \%(f=3)$ somewhat agreed, $21 \%(f=4)$ agreed, and $58 \%(f=11)$ strongly agreed. When given the statement, "the training led to a positive change in their instruction," $11 \%(f=2)$ somewhat disagreed, $16 \%(f=3)$ somewhat agreed, $32 \%(f=6)$ agreed, $42 \%(f=8)$ strongly agreed. When given the statement concerning their students improve learning, $5 \%(f=1)$ disagreed, $11 \%(f=2)$ somewhat disagreed, $16 \%(f=3)$ somewhat agreed, $26 \%(f=5)$ agreed, $42 \%(f=8)$ strongly agreed. 
Table 38

Post CASE Training ${ }^{a}$

\begin{tabular}{|c|c|c|c|c|c|c|c|c|c|c|c|c|}
\hline & \multicolumn{2}{|c|}{$\begin{array}{l}\text { Strongly } \\
\text { Disagree }\end{array}$} & \multicolumn{2}{|c|}{ Disagree } & \multicolumn{2}{|c|}{$\begin{array}{l}\text { Somewhat } \\
\text { Disagree }\end{array}$} & \multicolumn{2}{|c|}{ Somewhat Agree } & \multicolumn{2}{|c|}{ Agree } & \multicolumn{2}{|c|}{ Strongly Agree } \\
\hline & $f$ & $\%$ & $f$ & $\%$ & $f$ & $\%$ & $f$ & $\%$ & $f$ & $\%$ & $f$ & $\%$ \\
\hline $\begin{array}{l}\text { I was comfortable } \\
\text { using the curriculum } \\
\text { in the classroom. }\end{array}$ & 0 & .00 & 0 & .00 & 0 & .00 & 5 & 26.32 & 3 & 15.79 & 11 & 57.89 \\
\hline $\begin{array}{l}\text { My knowledge and } \\
\text { skills of the material } \\
\text { increased from the } \\
\text { training. }\end{array}$ & 0 & .00 & 0 & .00 & 1 & 5.26 & 3 & 15.79 & 4 & 21.05 & 11 & 57.89 \\
\hline $\begin{array}{l}\text { The training led to a } \\
\text { positive change in } \\
\text { my instruction. }\end{array}$ & 0 & .00 & 0 & .00 & 2 & 10.53 & 3 & 15.79 & 6 & 31.58 & 8 & 42.11 \\
\hline $\begin{array}{l}\text { My students learning } \\
\text { improved. }\end{array}$ & 0 & .00 & 1 & 5.26 & 2 & 10.53 & 3 & 15.79 & 5 & 26.32 & 8 & 42.11 \\
\hline
\end{tabular}

Note: ${ }^{\mathrm{a}}(n=19)$ 
Respondents were asked the extent to which they agreed or disagreed with statements concerning the CASE APT lesson plans. When given the statement," The APT course CASE lesson plans are user friendly to anyone who tries to use them," $5 \%(f=1)$ somewhat disagreed, $26 \%(f=5)$ somewhat agreed, $32 \%(f=6)$ agreed, $37 \%(f=7)$ strongly agreed (see Table 39). When given the statement, "The APT course CASE lesson plans \& contain the material to be taught in each lesson," $21 \%(f=4)$ somewhat agreed, 42\% ( $f=8)$ agreed, and 37\% $(f=7)$ strongly agreed. When given the statement, "The APT course CASE lesson plans contain the material to be taught in each unit," 5\% $(f=1)$ somewhat disagreed, $5 \%(f=1)$ somewhat agreed, $47 \%(f=9)$ agreed, and $42 \%(f$ = 8) strongly agreed. When given the statement, "The APT course CASE lesson plans overall contain the needed amount of material," $6 \%(f=1)$ somewhat disagreed, $11 \%(f$ =2) somewhat agreed, $44 \%(f=8)$ agreed, $39 \%(f=7)$ strongly agreed. 
Table 39

\section{CASE APT Lesson Plans}

\begin{tabular}{lllllllllll}
\hline & $\begin{array}{l}\text { Strongly } \\
\text { Disagree }\end{array}$ & Disagree & $\begin{array}{c}\text { Somewhat } \\
\text { Disagree }\end{array}$ & $\begin{array}{c}\text { Somewhat } \\
\text { Agree }\end{array}$ & Agree & Strongly Agree \\
\hline$f$ & $\%$ & $f$ & $\%$ & $f$ & $\%$ & $f$ & $\%$ & $f$ & $\%$ & $f$ \\
\hline
\end{tabular}

Plans are user friendly to anyone who tries to use them.

.00

5.26

$5 \quad 26.32$

$6 \quad 31.58$

$\begin{array}{ll}7 & 36.84\end{array}$

19

Plans contain the material to be taught in each lesson.

0

.00

0

$.00 \quad 0$

.00

4

21.05

8

$\begin{array}{lll}42.11 & 7 & 36.84\end{array}$

Plans contain the material to be taught in each unit.

0.

.00

.00

.00

5.26

1

\begin{tabular}{rrrrrr}
5.26 & 9 & 47.37 & 8 & 42.11 & 19 \\
& & & & & \\
11.11 & 8 & 44.44 & 7 & 38.89 & 18 \\
\hline
\end{tabular}

Plans overall

contain the needed

amount of material.

.00

$\begin{array}{lll}.00 \quad 1 & 5.56\end{array}$


Respondents were asked to what degree they agreed or disagreed with the incorporation of FFA and leadership aspects in the CASE curriculum as opposed to previous curriculums. For classroom and laboratory, $5 \%(f=1)$ agreed that its incorporation was inferior, $11 \%(f=2)$ agreed that its incorporation was equal to previous curriculums, $21 \%(f=4)$ agreed that its incorporation was superior and $63 \%(f=12)$ agreed that its incorporation was definitely superior (see Table 40). For FFA and leadership incorporation, $11 \%(f=2)$ agreed that CASE's incorporation was definitely inferior, $21 \%(f=4)$ agreed that it was inferior, $47 \%(f=9)$ agreed that it was equal to, and $21 \%(f=4)$ agreed that it was definitely superior. For Supervised Agriculture Experience (SAE), 5\% $(f=1)$ agreed that CASE's incorporation was definitely inferior, $16 \%(f=3)$ agreed that the incorporation was inferior, 53\% $(f=10)$ agreed that it was equal to, $5 \%(f=1)$ agreed that it was superior, and $21 \%(f=4)$ agreed that it was definitely superior. Concerning CASE's incorporation of all aspects of an Agricultural education Program, 11\% $(f=2)$ agreed that it was inferior, $37 \%(f=7)$ agreed it was equal to, 26\% $(f=5)$ agreed that it was superior, and $26 \%(f=5)$ agreed that it was definitely superior. 
Table 40

CASE Incorporation of Parts of the Agricultural Education Model ${ }^{a}$

\begin{tabular}{|c|c|c|c|c|c|c|c|c|c|c|}
\hline & \multicolumn{2}{|c|}{ Definitely Inferior } & \multicolumn{2}{|c|}{ Inferior } & \multicolumn{2}{|c|}{ Equal To } & \multicolumn{2}{|c|}{ Superior } & \multicolumn{2}{|c|}{ Definitely Superior } \\
\hline & $f$ & $\%$ & $f$ & $\%$ & $f$ & $\%$ & $f$ & $\%$ & $f$ & $\%$ \\
\hline $\begin{array}{l}\text { Classroom and } \\
\text { laboratory }\end{array}$ & 0 & .00 & 1 & 5.26 & 2 & 10.53 & 4 & 21.05 & 12 & 63.16 \\
\hline FFA and leadership & 2 & 10.53 & 4 & 21.05 & 9 & 47.37 & 0 & .00 & 4 & 21.05 \\
\hline $\begin{array}{l}\text { Supervised Agriculture } \\
\text { Experiences (SAE) }\end{array}$ & 1 & 5.26 & 3 & 15.79 & 10 & 52.63 & 1 & 5.26 & 4 & 21.05 \\
\hline $\begin{array}{l}\text { All aspects of an } \\
\text { Agricultural education } \\
\text { Program }\end{array}$ & 0 & .00 & 2 & 10.53 & 7 & 36.84 & 5 & 26.32 & 5 & 26.32 \\
\hline
\end{tabular}


Respondents were asked the degree to which they agreed or disagreed with statements concerning their student's perceptions of the CASE curriculum APT course. When given the statement, "Students enjoyed the creativity of the APT course lessons," $11 \%(f=2)$ somewhat disagreed, $21 \%(f=4)$ somewhat agreed, $53 \%(f=10)$ agreed, and $16 \%(f=3)$ strongly agreed (see Table 41$)$. When given the statement, "Students enjoyed the spontaneity of the APT course lessons," $16 \%(f=3)$ somewhat disagreed, $32 \%(f=6)$ somewhat agreed, $37 \%(f=7)$ agreed, and $16 \%(f=3)$ strongly agreed. When given the statement, "Students enjoyed the APT course," 5\% $(f=1)$ disagreed, 11\% $(f=2)$ somewhat disagreed, $37 \%(f=7)$ somewhat agreed, $32 \%(f=6)$ agreed, and $16 \%(f=3)$ strongly agreed. 
Table 41

Student Perceptions of CASE Creativity as Perceived by Their Teachers ${ }^{a}$

\begin{tabular}{|c|c|c|c|c|c|c|c|c|c|c|c|c|}
\hline & \multicolumn{2}{|c|}{$\begin{array}{l}\text { Strongly } \\
\text { Disagree }\end{array}$} & \multicolumn{2}{|c|}{ Disagree } & \multicolumn{2}{|c|}{$\begin{array}{l}\text { Somewhat } \\
\text { Disagree }\end{array}$} & \multicolumn{2}{|c|}{ Somewhat Agree } & \multicolumn{2}{|c|}{ Agree } & \multicolumn{2}{|c|}{ Strongly Agree } \\
\hline & $f$ & $\%$ & $f$ & $\%$ & $f$ & $\%$ & $f$ & $\%$ & $f$ & $\%$ & $f$ & $\%$ \\
\hline $\begin{array}{l}\text { Students enjoyed the } \\
\text { creativity of the APT } \\
\text { course lessons. }\end{array}$ & 0 & .00 & 0 & .00 & 2 & 10.53 & 4 & 21.05 & 10 & 52.63 & 3 & 15.79 \\
\hline $\begin{array}{l}\text { Students enjoyed the } \\
\text { spontaneity of the }\end{array}$ & & & & & & & & & & & & \\
\hline APT course lessons. & 0 & .00 & 0 & .00 & 3 & 15.79 & 6 & 31.58 & 7 & 36.84 & 3 & 15.79 \\
\hline $\begin{array}{l}\text { Students enjoyed the } \\
\text { APT course. }\end{array}$ & 0 & .00 & 1 & 5.26 & 2 & 10.53 & 7 & 36.84 & 6 & 31.58 & 3 & 15.79 \\
\hline
\end{tabular}

Note: ${ }^{\mathrm{a}}(n=19)$ 
Respondents were asked to select a number from 1-100 to represent the level of students' positive excitement over time for the CASE curriculum APT course. For students' positive level of excitement of the beginning of the course, the mean was 52.74 and the standard deviation was 29.72 (see Table 42). For students' positive excitement in the middle of the course, the mean was 55.79 with the standard deviation of 23.47 . For students' positive excitement at the end of the course, the mean was 63.53 and the standard deviation was 21.38.

Table 42

Students' Levels of Positive Excitement Over Time

\begin{tabular}{lcc}
\hline & M & SD \\
\hline $\begin{array}{l}\text { Students' positive excitement at the beginning } \\
\text { of the course. }\end{array}$ & 52.74 & 29.72 \\
$\begin{array}{l}\text { Students' positive excitement in the middle of } \\
\text { course. }\end{array}$ & 55.79 & 23.47 \\
$\begin{array}{l}\text { Students' positive excitement at the end of the } \\
\text { course. }\end{array}$ & 63.53 & 21.38 \\
\begin{tabular}{l} 
Average \\
\hline
\end{tabular} & 57.35 & 24.86 \\
\hline
\end{tabular}




\section{Natural Resources and Ecology (NRE)}

Respondents were asked about the training for the Natural Resources and Ecology (NRE) course. When asked if they felt the training prepared them to implement the course, $3 \%(f=1)$ somewhat disagreed, $14 \%(f=5)$ somewhat agreed, $49 \%(f=13)$ agreed, and $35 \%$ of the respondents $(f=13)$ strongly agreed (see Table 43 ). Respondents were asked the degree to which they agreed and disagreed that the training prepared them to use the lesson plans in the classroom. Of those who responded, 3\% $(f=1)$ somewhat disagreed, $14 \%(f=5)$ somewhat agreed, $46 \%(f=17)$ agreed, and 38\% $(f=14)$ strongly agreed. Respondents were asked the degree to which they agreed or disagreed that the training prepared them to use the course Power Points in the classroom. Of the respondents, 3\% $(f=1)$ strongly disagreed, $5 \%(f=2)$ disagreed, $8 \%(f=3)$ somewhat agreed, $49 \%(f=13)$ agreed, and 35\% $(f=13)$ strongly agreed. 
Table 43

CASE Training Prepared Individuals to: ${ }^{a}$

\begin{tabular}{|c|c|c|c|c|c|c|c|c|c|c|c|c|}
\hline & \multicolumn{2}{|c|}{$\begin{array}{l}\text { Strongly } \\
\text { Disagree }\end{array}$} & \multicolumn{2}{|c|}{ Disagree } & \multicolumn{2}{|c|}{$\begin{array}{l}\text { Somewhat } \\
\text { Disagree }\end{array}$} & \multicolumn{2}{|c|}{ Somewhat Agree } & \multicolumn{2}{|c|}{ Agree } & \multicolumn{2}{|c|}{ Strongly Agree } \\
\hline & $f$ & $\%$ & $f$ & $\%$ & $f$ & $\%$ & $f$ & $\%$ & $f$ & $\%$ & $f$ & $\%$ \\
\hline Implement the NRE & & & & & & & & & & & & \\
\hline CASE course & 0 & .00 & 0 & .00 & 1 & 2.70 & 5 & 13.51 & 18 & 48.65 & 13 & 35.14 \\
\hline $\begin{array}{l}\text { Use the CASE } \\
\text { curriculum NRE } \\
\text { course lesson plans }\end{array}$ & 0 & .00 & 0 & .00 & 1 & 2.70 & 5 & 13.51 & 17 & 45.95 & 14 & 37.84 \\
\hline $\begin{array}{l}\text { Use the NRE course } \\
\text { CASE Power Points } \\
\text { included in the } \\
\text { curriculum }\end{array}$ & 1 & 2.70 & 0 & .00 & 2 & 5.41 & 3 & 8.11 & 18 & 48.65 & 13 & 35.14 \\
\hline
\end{tabular}


Respondents were asked if they required assistance from CASE support staff in implementing the CASE course NRE in their classroom. Of those responding, $19 \%(f=$ 7) required assistance, $81 \%(f=30)$ did not (see Table 44$)$.

Table 44

Respondents Who Required Assistance from CASE When Implementing the Course in a Classroom $^{a}$

\begin{tabular}{lcc}
\hline & $f$ & $\%$ \\
\hline Yes & 7 & 18.92 \\
No & 30 & 81.08 \\
\hline
\end{tabular}

Note: ${ }^{\mathrm{a}}(n=37)$

The respondents who required assistance from CASE support staff when implementing the NRE course were given statements, and asked the extent to which they agreed or disagreed. When given the statement "I received assistance from a CASE staff member or lead teacher when implementing the CASE curriculum," $20 \%(f=1)$ somewhat agreed, $40 \%(f=2)$ agreed, and 40\% $(f=2)$ strongly agreed (see Table 45$)$. When given the statement, "The professional development was helpful for problems that arose over time using the curriculum," 20\% $(f=1)$ agreed, and 80\% $(f=4)$ strongly agreed. When given the statement "The professional development aspect involved interactions through the National Association of Agricultural Educators Community of Practice Forum," $40 \%(f=2)$ agreed, and 60\% $(f=3)$ strongly agreed. 
Table 45

Aspects of Post CASE Training Assistance ${ }^{a}$

\begin{tabular}{|c|c|c|c|c|c|c|c|c|c|c|c|c|}
\hline & \multicolumn{2}{|c|}{$\begin{array}{l}\text { Strongly } \\
\text { Disagree }\end{array}$} & \multicolumn{2}{|c|}{ Disagree } & \multicolumn{2}{|c|}{$\begin{array}{l}\text { Somewhat } \\
\text { Disagree }\end{array}$} & \multicolumn{2}{|c|}{ Somewhat Agree } & \multicolumn{2}{|c|}{ Agree } & \multicolumn{2}{|c|}{ Strongly Agree } \\
\hline & $f$ & $\%$ & $f$ & $\%$ & $f$ & $\%$ & $f$ & $\%$ & $f$ & $\%$ & $f$ & $\%$ \\
\hline $\begin{array}{l}\text { Received assistance } \\
\text { from a CASE staff } \\
\text { member or lead } \\
\text { teacher }\end{array}$ & 0 & .00 & 0 & .00 & 0 & .00 & 1 & 20.00 & 2 & 40.00 & 2 & 40.00 \\
\hline $\begin{array}{l}\text { Helpful for problems } \\
\text { that arose over time } \\
\text { using the curriculum }\end{array}$ & 0 & .00 & 0 & .00 & 0 & .00 & 0 & .00 & 1 & 20.00 & 4 & 80.00 \\
\hline $\begin{array}{l}\text { Interactions through } \\
\text { the National } \\
\text { Association of } \\
\text { Agricultural } \\
\text { Educators } \\
\text { Community of } \\
\text { Practice Forum }\end{array}$ & 0 & .00 & 0 & .00 & 0 & .00 & 0 & .00 & 2 & 40.00 & 3 & 60.00 \\
\hline
\end{tabular}

Note: ${ }^{\text {a }}(n=5)$ 
Respondents were asked how they felt in their classrooms after the CASE training. When given the statement, "I was comfortable using the curriculum in the classroom," 19\% $(f=7)$ somewhat agreed, 42\% $(f=15)$ agreed and 39\% $(f=14)$ strongly agreed (see Table 46). When given the statement, "my knowledge and skills of the material increased from the training," $6 \%(f=2)$ somewhat disagreed, $11 \%(f=4)$ somewhat agreed, 47\% ( $f=17)$ agreed, and 36\% $(f=13)$ strongly agreed. When given the statement, "the training led to a positive change in their instruction," $3 \%(f=1)$ strongly disagreed, $17 \%(f=51)$ somewhat agreed, $56 \%(f=20)$ agreed, $31 \%(f=11)$ strongly agreed. When given the statement concerning their students improve learning, $12 \%(f=4)$ somewhat agreed, 54\% $(f=19)$ agreed, 34\% $(f=12)$ strongly agreed. 
Table 46

\section{Post CASE Training}

\begin{tabular}{|c|c|c|c|c|c|c|c|c|c|c|c|c|c|}
\hline & \multicolumn{2}{|c|}{$\begin{array}{l}\text { Strongly } \\
\text { Disagree }\end{array}$} & \multicolumn{2}{|c|}{ Disagree } & \multicolumn{2}{|c|}{$\begin{array}{l}\text { Somewhat } \\
\text { Disagree }\end{array}$} & \multicolumn{2}{|c|}{$\begin{array}{c}\text { Somewhat } \\
\text { Agree }\end{array}$} & \multicolumn{2}{|c|}{ Agree } & \multicolumn{2}{|c|}{ Strongly Agree } & \multirow[b]{2}{*}{$n$} \\
\hline & $f$ & $\%$ & $f$ & $\%$ & $f$ & $\%$ & $f$ & $\%$ & $f$ & $\%$ & $f$ & $\%$ & \\
\hline $\begin{array}{l}\text { I was comfortable } \\
\text { using the } \\
\text { curriculum in the } \\
\text { classroom. }\end{array}$ & 0 & .00 & 0 & .00 & 0 & .00 & 7 & 19.44 & 15 & 41.67 & 14 & 38.89 & 36 \\
\hline $\begin{array}{l}\text { My knowledge and } \\
\text { skills of the } \\
\text { material increased } \\
\text { from the training. }\end{array}$ & 0 & .00 & 0 & .00 & 2 & 5.56 & 4 & 11.11 & 17 & 47.22 & 13 & 36.11 & 36 \\
\hline $\begin{array}{l}\text { The training led to } \\
\text { a positive change in } \\
\text { my instruction. }\end{array}$ & 1 & 2.78 & 0 & .00 & 0 & .00 & 4 & 11.11 & 20 & 55.56 & 11 & 30.56 & 36 \\
\hline $\begin{array}{l}\text { My students } \\
\text { learning improved. }\end{array}$ & 0 & .00 & 0 & .00 & 0 & .00 & 4 & 11.43 & 19 & 54.29 & 12 & 34.29 & 35 \\
\hline
\end{tabular}


Respondents were asked the extent to which they agreed or disagreed with statements concerning the CASE NRE lesson plans. When given the statement," The NRE course CASE lesson plans are user friendly to anyone who tries to use them," $3 \%(f=1)$ somewhat disagree, $25 \%(f=9)$ somewhat agreed, $42 \%(f=15)$ agreed, $31 \%(f=11)$ strongly agreed (see Table 47$)$. When given the statement, "The NRE course CASE lesson plans \& contain the material to be taught in each lesson," $3 \%(f=10)$ somewhat disagreed, $8 \%(f=3)$ somewhat agreed, $53 \%(f=$ 19) agreed, and $36 \%(f=13)$ strongly agreed. When given the statement, "The NRE course CASE lesson plans contain the material to be taught in each unit," $3 \%(f=1)$ somewhat disagreed, $11 \%(f=17)$ somewhat agreed, $47 \%(f=17)$ agreed, and $39 \%(f=14)$ strongly agreed. When given the statement, "The NRE course CASE lesson plans overall contain the needed amount of material," 3\% $(f=1)$ somewhat disagreed, 11\% $(f=4)$ somewhat agreed, 50\% $(f=18)$ agreed, and $36 \%(f=13)$ strongly agreed. 
Table 47

\section{CASE NRE Lesson Plans ${ }^{a}$}

\begin{tabular}{|c|c|c|c|c|c|c|c|c|c|c|c|c|}
\hline & \multicolumn{2}{|c|}{$\begin{array}{l}\text { Strongly } \\
\text { Disagree }\end{array}$} & \multicolumn{2}{|c|}{ Disagree } & \multicolumn{2}{|c|}{$\begin{array}{l}\text { Somewhat } \\
\text { Disagree }\end{array}$} & \multicolumn{2}{|c|}{ Somewhat Agree } & \multicolumn{2}{|c|}{ Agree } & \multicolumn{2}{|c|}{ Strongly Agree } \\
\hline & $f$ & $\%$ & $f$ & $\%$ & $f$ & $\%$ & $f$ & $\%$ & $f$ & $\%$ & $f$ & $\%$ \\
\hline $\begin{array}{l}\text { Plans are user } \\
\text { friendly to anyone } \\
\text { who tries to use } \\
\text { them. }\end{array}$ & 0 & .00 & 0 & .00 & 1 & 2.78 & 9 & 25.00 & 15 & 41.67 & 11 & 30.56 \\
\hline $\begin{array}{l}\text { Plans contain the } \\
\text { material to be taught } \\
\text { in each lesson. }\end{array}$ & 0 & .00 & 0 & .00 & 1 & 2.78 & 3 & 8.33 & 19 & 52.78 & 13 & 36.11 \\
\hline $\begin{array}{l}\text { Plans contain the } \\
\text { material to be taught } \\
\text { in each unit. }\end{array}$ & 0 & .00 & 0 & .00 & 1 & 2.78 & 4 & 11.11 & 17 & 47.22 & 14 & 38.89 \\
\hline $\begin{array}{l}\text { Plans overall contain } \\
\text { the needed amount of } \\
\text { material. }\end{array}$ & 0 & .00 & 0 & .00 & 1 & 2.78 & 4 & 11.11 & 18 & 50.00 & 13 & 36.11 \\
\hline
\end{tabular}

Note: ${ }^{\mathrm{a}}(n=36)$ 
Respondents were asked to what degree they agreed or disagreed with the incorporation of FFA and leadership aspects in the CASE curriculum as opposed to previous curriculums. For classroom and laboratory, $14 \%(f=5)$ agreed that its incorporation was equal to previous curriculums, $58 \%(f=21)$ agreed that its incorporation was superior and $28 \%(f=10)$ agreed that its incorporation was definitely superior (see Table 48). For FFA and leadership incorporation, 9\% $(f=3)$ agreed that CASE's incorporation was definitely inferior, $20 \%(f=7)$ agreed that it was inferior, $49 \%$ $(f=17)$ agreed that it was equal to, $9 \%(f=9)$ agreed that it was superior, and $14 \%(f=5)$ agreed that it was definitely superior. For Supervised Agriculture Experience (SAE), 5\% $(f=14)$ agreed that CASE's incorporation was definitely inferior, $6 \%(f=2)$ agreed that the incorporation was definitely inferior, $11 \%(f=4)$ agreed that it was inferior, $56 \%(f=$ 20) agreed that it was equal to, $14 \%(f=5)$ agreed that it was superior, and $14 \%(f=5)$ agreed that it was definitely superior. Concerning CASE's incorporation of all aspects of an Agricultural education Program, 3\% ( $f=1)$ agreed that its incorporation was definitely inferior, 3\% $(f=1)$ agreed that it was inferior, 33\% $(f=12)$ agreed it was equal to, $47 \%(f$ $=17)$ agreed that it was superior, and $14 \%(f=5)$ agreed that it was definitely superior. 
Table 48

CASE Incorporation of Parts of the Agricultural Education Model

\begin{tabular}{|c|c|c|c|c|c|c|c|c|c|c|c|}
\hline & \multicolumn{2}{|c|}{ Definitely Inferior } & \multicolumn{2}{|c|}{ Inferior } & \multicolumn{2}{|c|}{ Equal To } & \multicolumn{2}{|c|}{ Superior } & \multicolumn{2}{|c|}{$\begin{array}{l}\text { Definitely } \\
\text { Superior }\end{array}$} & \multirow[b]{2}{*}{$n$} \\
\hline & $f$ & $\%$ & $f$ & $\%$ & $f$ & $\%$ & $f$ & $\%$ & $f$ & $\%$ & \\
\hline \multicolumn{12}{|l|}{ Classroom and } \\
\hline laboratory & 0 & .00 & 0 & .00 & 5 & 13.89 & 21 & 58.33 & 10 & 27.78 & 36 \\
\hline FFA and leadership & 3 & 8.57 & 7 & 20.00 & 17 & 48.57 & 3 & 8.57 & 5 & 14.29 & 35 \\
\hline \multicolumn{12}{|l|}{ Supervised Agriculture } \\
\hline Experiences (SAE) & 2 & 5.56 & 4 & 11.11 & 20 & 55.56 & 5 & 13.89 & 5 & 13.89 & 36 \\
\hline \multicolumn{12}{|l|}{$\begin{array}{l}\text { All aspects of an } \\
\text { Agricultural education }\end{array}$} \\
\hline Program & 1 & 2.78 & 1 & 2.78 & 12 & 33.33 & 17 & 47.22 & 5 & 13.89 & 36 \\
\hline
\end{tabular}


Respondents were asked the degree to which they agreed or disagreed with statements concerning their student's perceptions of the CASE curriculum NRE course. When given the statement, "Students enjoyed the creativity of the NRE course lessons," $3 \%(f=1)$ somewhat disagreed, 20\% $(f=7)$ somewhat agreed, $57 \%(f=20)$ agreed, and $20 \%(f=7)$ strongly agreed (see Table 49). When given the statement, "Students enjoyed the spontaneity of the NRE course lessons," $3 \%(f=1)$ somewhat disagreed, $34 \%(f=12)$ somewhat agreed, $43 \%(f=15)$ agreed, $20 \%(f=7)$ strongly agreed. When given the statement, "Students enjoyed the NRE course," 3\% $(f=1)$ somewhat disagreed, $31 \%(f=$ 11) somewhat agreed, $43 \%(f=15)$ agreed, and $23 \%(f=8)$ strongly agreed. 
Table 49

Student Perception of CASE Creativity as Perceived by Their Teachers ${ }^{a}$

\begin{tabular}{|c|c|c|c|c|c|c|c|c|c|c|c|c|}
\hline & \multicolumn{2}{|c|}{$\begin{array}{l}\text { Strongly } \\
\text { Disagree }\end{array}$} & \multicolumn{2}{|c|}{ Disagree } & \multicolumn{2}{|c|}{$\begin{array}{l}\text { Somewhat } \\
\text { Disagree }\end{array}$} & \multicolumn{2}{|c|}{ Somewhat Agree } & \multicolumn{2}{|c|}{ Agree } & \multicolumn{2}{|c|}{ Strongly Agree } \\
\hline & $f$ & $\%$ & $f$ & $\%$ & $f$ & $\%$ & $f$ & $\%$ & $f$ & $\%$ & $f$ & $\%$ \\
\hline $\begin{array}{l}\text { Students enjoyed the } \\
\text { creativity of the NRE } \\
\text { course lessons. }\end{array}$ & 0 & .00 & 0 & .00 & 1 & 2.86 & 7 & 20.00 & 20 & 57.14 & 7 & 20.00 \\
\hline $\begin{array}{l}\text { Students enjoyed the } \\
\text { spontaneity of the }\end{array}$ & & & & & & & & & & & & \\
\hline NRE course lessons. & 0 & .00 & 0 & .00 & 1 & 2.86 & 12 & 34.29 & 15 & 42.86 & 7 & 20.00 \\
\hline $\begin{array}{l}\text { Students enjoyed the } \\
\text { NRE course. }\end{array}$ & 0 & .00 & 0 & .00 & 1 & 2.86 & 11 & 31.43 & 15 & 42.86 & 8 & 22.86 \\
\hline
\end{tabular}

Note: ${ }^{\mathrm{a}}(n=35)$ 
Respondents were asked to select a number from 1-100 to represent the level of students' positive excitement over time for the CASE curriculum NRE course. For students' positive level of excitement of the beginning of the course, the mean was 51.29 and the standard deviation was 25.54 (see Table 50). For students' positive excitement in the middle of the course, the mean was 62.23 with the standard deviation of 18.20 . For students' positive excitement at the end of the course, the mean was 75.06 and the standard deviation was 20.27 .

Table 50

Students' Levels of Positive Excitement Over Time

M SD

Students' positive excitement at the beginning of the course.

Students' positive excitement in the middle of the course.

Students' excitement at the end of the course.

75.06

Average

62.87

\section{Plant and Animal Biotechnology (APB)}

Respondents were asked about the training for the Plant and Animal Biotechnology course. When asked about their feelings towards the training and if they felt it prepared them to implement the course, $4 \%(f=1)$ somewhat agreed, $26 \%(f=7)$ somewhat agreed, 33\% ( $f=9)$ agreed, and $37 \%$ of the respondents $(f=10)$ strongly agreed (see Table 51). Respondents were asked the degree to which they agreed and disagreed that the training prepared them to use the lesson plans in the classroom. Of 
those who responded, $19 \%(f=5)$ somewhat agreed, $37 \%(f=10)$ agreed, and $44 \%(f=$ 12) strongly agreed. Respondents were asked the degree to which they agreed or disagreed that the training prepared them to use the course Power Points in the classroom. Of the respondents, $7 \%(f=2)$ disagreed, $4 \%(f=1)$ somewhat disagreed, $26 \%(f=7)$ somewhat agreed, $30 \%(f=8)$ agreed, and 33\% $(f=9)$ strongly agreed. 
Table 51

CASE Training Prepared Individuals to: ${ }^{a}$

\begin{tabular}{|c|c|c|c|c|c|c|c|c|c|c|c|c|}
\hline & \multicolumn{2}{|c|}{$\begin{array}{l}\text { Strongly } \\
\text { Disagree }\end{array}$} & \multicolumn{2}{|c|}{ Disagree } & \multicolumn{2}{|c|}{$\begin{array}{l}\text { Somewhat } \\
\text { Disagree }\end{array}$} & \multicolumn{2}{|c|}{ Somewhat Agree } & \multicolumn{2}{|c|}{ Agree } & \multicolumn{2}{|c|}{ Strongly Agree } \\
\hline & $f$ & $\%$ & $f$ & $\%$ & $f$ & $\%$ & $f$ & $\%$ & $f$ & $\%$ & $f$ & $\%$ \\
\hline $\begin{array}{l}\text { Implement the APB } \\
\text { CASE course }\end{array}$ & 0 & .00 & 0 & .00 & 1 & 3.70 & 7 & 25.93 & 9 & 33.33 & 10 & 37.04 \\
\hline $\begin{array}{l}\text { Use the CASE } \\
\text { curriculum APB } \\
\text { course lesson plans }\end{array}$ & 0 & .00 & 0 & .00 & 0 & .00 & 5 & 18.52 & 10 & 37.04 & 12 & 44.44 \\
\hline $\begin{array}{l}\text { Use the APB course } \\
\text { CASE Power Points } \\
\text { included in the } \\
\text { curriculum }\end{array}$ & 0 & .00 & 2 & 7.41 & 1 & 3.70 & 7 & 25.93 & 8 & 29.63 & 9 & 33.33 \\
\hline
\end{tabular}


Respondents were asked if they required assistance from CASE support staff in implementing the CASE course APB in their classroom. Of those responding, $63 \%(f=$ 17) required assistance, $37 \%(f=10)$ did not (see Table 52).

Table 52

Respondents Who Required Assistance from CASE When Implementing the Course in a Classroom $^{a}$

\begin{tabular}{lcc}
\hline & $f$ & $\%$ \\
\hline Yes & 17 & 62.96 \\
No & 10 & 37.04 \\
\hline
\end{tabular}

Note: ${ }^{\mathrm{a}}(n=27)$

The respondents who required assistance from CASE support staff when implementing the APB course were given statements, and asked the extent to which they agreed or disagreed. When given the statement "I received assistance from a CASE staff member or lead teacher when implementing the CASE curriculum," $12 \%(f=2)$ somewhat disagreed, $12 \%(f=2)$ somewhat agreed, $35 \%(f=6)$ agreed, and $41 \%(f=7)$ strongly agreed (see Table 53). When given the statement, "The professional development was helpful for problems that arose over time using the curriculum," $6 \%(f$ $=2)$ somewhat disagreed, $29 \%(f=5)$ somewhat agreed, $24 \%(f=4)$ agreed, and $41 \%(f=$ 7) strongly agreed. When given the statement "The professional development aspect involved interactions through the National Association of Agricultural Educators Community of Practice Forum," 29\% $(f=5)$ somewhat agreed, 29\% (f=5) agreed, and $41 \%(f=7)$ strongly agreed. 
Table 53

Aspects of Post CASE Training Assistance ${ }^{a}$

\begin{tabular}{|c|c|c|c|c|c|c|c|c|c|c|c|c|}
\hline & \multicolumn{2}{|c|}{$\begin{array}{l}\text { Strongly } \\
\text { Disagree }\end{array}$} & \multicolumn{2}{|c|}{ Disagree } & \multicolumn{2}{|c|}{$\begin{array}{l}\text { Somewhat } \\
\text { Disagree }\end{array}$} & \multicolumn{2}{|c|}{ Somewhat Agree } & \multicolumn{2}{|c|}{ Agree } & \multicolumn{2}{|c|}{ Strongly Agree } \\
\hline & $f$ & $\%$ & $f$ & $\%$ & $f$ & $\%$ & $f$ & $\%$ & $f$ & $\%$ & $f$ & $\%$ \\
\hline $\begin{array}{l}\text { Received assistance } \\
\text { from a CASE staff } \\
\text { member or lead } \\
\text { teacher }\end{array}$ & 0 & .00 & 0 & .00 & 2 & 11.76 & 2 & 11.76 & 6 & 35.29 & 7 & 41.18 \\
\hline $\begin{array}{l}\text { Helpful for problems } \\
\text { that arose over time } \\
\text { using the curriculum. }\end{array}$ & 0 & .00 & 0 & .00 & 1 & 5.88 & 5 & 29.41 & 4 & 23.53 & 7 & 41.18 \\
\hline $\begin{array}{l}\text { Interactions through } \\
\text { the National } \\
\text { Association of } \\
\text { Agricultural } \\
\text { Educators } \\
\text { Community of } \\
\text { Practice Forum }\end{array}$ & 0 & .00 & 0 & .00 & 0 & .00 & 5 & 29.41 & 5 & 29.41 & 7 & 41.18 \\
\hline
\end{tabular}


Respondents were asked how they felt in their classrooms after the CASE training. When given the statement, "I was comfortable using the curriculum in the classroom," 4\% $(f=1)$ somewhat disagreed, 30\% $(f=8)$ somewhat agreed, 37\% $(f=10)$ agreed and 30\% $(f=8)$ strongly agreed (see Table 54). When given the statement, "my knowledge and skills of the material increased from the training," $4 \%(f=1)$ somewhat disagreed, $11 \%(f=3)$ somewhat agreed, 33\% $(f=9)$ agreed, and 52\% $(f=14)$ strongly agreed. When given the statement, "the training led to a positive change in their instruction," 4\% $(f=1)$ somewhat disagreed, $1 \%(f=3)$ somewhat agreed, $33 \%(f=9)$ agreed, and 52\% $(f=14)$ strongly agreed. When given the statement concerning their students improve learning, $22 \%(f=6)$ somewhat agreed, $26 \%(f=7)$ agreed, $52 \%(f=$ 14) strongly agreed. 
Table 54

Post CASE Training ${ }^{a}$

\begin{tabular}{|c|c|c|c|c|c|c|c|c|c|c|c|c|}
\hline & \multicolumn{2}{|c|}{$\begin{array}{l}\text { Strongly } \\
\text { Disagree }\end{array}$} & \multicolumn{2}{|c|}{ Disagree } & \multicolumn{2}{|c|}{$\begin{array}{l}\text { Somewhat } \\
\text { Disagree }\end{array}$} & \multicolumn{2}{|c|}{ Somewhat Agree } & \multicolumn{2}{|c|}{ Agree } & \multicolumn{2}{|c|}{ Strongly Agree } \\
\hline & $f$ & $\%$ & $f$ & $\%$ & $f$ & $\%$ & $f$ & $\%$ & $f$ & $\%$ & $f$ & $\%$ \\
\hline $\begin{array}{l}\text { I was comfortable } \\
\text { using the curriculum } \\
\text { in the classroom. }\end{array}$ & 0 & .00 & 0 & .00 & 1 & 3.70 & 8 & 29.63 & 10 & 37.04 & 8 & 29.63 \\
\hline $\begin{array}{l}\text { My knowledge and } \\
\text { skills of the material } \\
\text { increased from the } \\
\text { training. }\end{array}$ & 0 & .00 & 0 & .00 & 0 & .00 & 3 & 11.11 & 10 & 37.04 & 14 & 51.85 \\
\hline $\begin{array}{l}\text { The training led to a } \\
\text { positive change in } \\
\text { my instruction. }\end{array}$ & 0 & .00 & 0 & .00 & 1 & 3.70 & 3 & 11.11 & 9 & 33.33 & 14 & 51.85 \\
\hline $\begin{array}{l}\text { My students learning } \\
\text { improved. }\end{array}$ & 0 & .00 & 0 & .00 & 0 & .00 & 6 & 22.22 & 7 & 25.93 & 14 & 51.85 \\
\hline
\end{tabular}

Note: ${ }^{\text {a }}(n=27)$ 
Respondents were asked the extent to which they agreed or disagreed with statements concerning the CASE APB lesson plans. When given the statement," The APB course CASE lesson plans are user friendly to anyone who tries to use them," $7 \%(f$ = 2) somewhat disagreed, $26 \%(f=2)$ somewhat agreed, $41 \%(f=11)$ agreed, $26 \%(f=7)$ strongly agreed (see Table 55). When given the statement, "The APB course CASE lesson plans \& contain the material to be taught in each lesson," $4 \%(f=1)$ strongly disagreed, 30\% $(f=8)$ somewhat agreed, 37\% $(f=10)$ agreed, and 30\% $(f=8)$ strongly agreed. When given the statement, "The APB course CASE lesson plans contain the material to be taught in each unit," $4 \%(f=1)$ strongly disagreed, $19 \%(f=5)$ somewhat agreed, 37\% $(f=10)$ agreed, and $41 \%(f=11)$ strongly agreed. When given the statement, "The APB course CASE lesson plans overall contain the needed amount of material," $4 \%(f=1)$ strongly disagreed, $4 \%(f=1)$ somewhat disagreed, $26 \%(f=7)$ somewhat agreed, $30 \%(f=8)$ agreed, and 37\% $(f=10)$ strongly agreed. 
Table 55

\section{CASE APB Lesson Plans ${ }^{a}$}

\begin{tabular}{|c|c|c|c|c|c|c|c|c|c|c|c|c|}
\hline & \multicolumn{2}{|c|}{$\begin{array}{l}\text { Strongly } \\
\text { Disagree }\end{array}$} & \multicolumn{2}{|c|}{ Disagree } & \multicolumn{2}{|c|}{$\begin{array}{l}\text { Somewhat } \\
\text { Disagree }\end{array}$} & \multicolumn{2}{|c|}{ Somewhat Agree } & \multicolumn{2}{|c|}{ Agree } & \multicolumn{2}{|c|}{ Strongly Agree } \\
\hline & $f$ & $\%$ & $f$ & $\%$ & $f$ & $\%$ & $f$ & $\%$ & $f$ & $\%$ & $f$ & $\%$ \\
\hline $\begin{array}{l}\text { Plans are user } \\
\text { friendly to anyone } \\
\text { who tries to use } \\
\text { them. }\end{array}$ & 0 & .00 & 0 & .00 & 2 & 7.41 & 7 & 25.93 & 11 & 40.74 & 7 & 25.93 \\
\hline $\begin{array}{l}\text { Plans contain the } \\
\text { material to be taught } \\
\text { in each lesson. }\end{array}$ & 1 & 3.70 & 0 & .00 & 0 & .00 & 8 & 29.63 & 10 & 37.04 & 8 & 29.63 \\
\hline $\begin{array}{l}\text { Plans contain the } \\
\text { material to be taught } \\
\text { in each unit }\end{array}$ & 1 & 3.70 & 0 & .00 & 0 & .00 & 5 & 18.52 & 10 & 37.04 & 11 & 40.74 \\
\hline $\begin{array}{l}\text { Plans overall contain } \\
\text { the needed amount of } \\
\text { material }\end{array}$ & 1 & 3.70 & 0 & .00 & 1 & 3.70 & 7 & 25.93 & 8 & 29.63 & 10 & 37.04 \\
\hline
\end{tabular}

Note: ${ }^{\mathrm{a}}(n=27)$ 
Respondents were asked to what degree they agreed or disagreed with the incorporation of FFA and leadership aspects in the CASE curriculum as opposed to previous curriculums. For classroom and laboratory, $7 \%(f=2)$ agreed that its incorporation was equal to previous curriculums, 33\% $(f=9)$ agreed that its incorporation was superior and $59 \%(f=16)$ agreed that its incorporation was definitely superior (see Table 56). For FFA and leadership incorporation, $8 \%(f=2)$ agreed that CASE's incorporation was definitely inferior, $12 \%(f=3)$ agreed that it was inferior, $50 \%(f=13)$ agreed that it was equal to, $23 \%(f=6)$ agreed that it was superior, and $8 \%(f=2)$ agreed that it was definitely superior. For Supervised Agriculture Experience (SAE), $8 \%(f=2)$ agreed that CASE's incorporation was definitely inferior, $12 \%(f=3)$ agreed that the incorporation was inferior, $42 \%(f=11)$ agreed that it was equal to, $27 \%(f=7)$ agreed that it was superior, and $12 \%(f=3)$ agreed that it was definitely superior. Concerning CASE's incorporation of all aspects of an Agricultural education Program, $4 \%(f=1)$ agreed that its incorporation was inferior, $27 \%(f=7)$ agreed it was equal to, $46 \%(f=12)$ agreed that it was superior, and $23 \%(f=6)$ agreed that it was definitely superior. 
Table 56

CASE Incorporation of Parts of the Agricultural Education Model

\begin{tabular}{|c|c|c|c|c|c|c|c|c|c|c|c|}
\hline & \multicolumn{2}{|c|}{ Definitely Inferior } & \multicolumn{2}{|c|}{ Inferior } & \multicolumn{2}{|c|}{ Equal To } & \multicolumn{2}{|c|}{ Superior } & \multicolumn{2}{|c|}{$\begin{array}{c}\text { Definitely } \\
\text { Superior }\end{array}$} & \multirow[b]{2}{*}{$n$} \\
\hline & $f$ & $\%$ & $f$ & $\%$ & $f$ & $\%$ & $f$ & $\%$ & $f$ & $\%$ & \\
\hline $\begin{array}{l}\text { Classroom and } \\
\text { laboratory }\end{array}$ & 0 & .00 & 0 & .00 & 2 & 7.41 & 9 & 33.33 & 16 & 59.26 & 27 \\
\hline FFA and leadership & 2 & 7.69 & 3 & 11.54 & 13 & 50.00 & 6 & 23.08 & 2 & 7.69 & 26 \\
\hline $\begin{array}{l}\text { Supervised Agriculture } \\
\text { Experiences (SAE) }\end{array}$ & 2 & 7.69 & 3 & 11.54 & 11 & 42.31 & 7 & 26.92 & 3 & 11.54 & 26 \\
\hline $\begin{array}{l}\text { All aspects of an } \\
\text { Agricultural Education } \\
\text { Program }\end{array}$ & 0 & .00 & 1 & 3.85 & 7 & 26.92 & 12 & 46.15 & 6 & 23.08 & 26 \\
\hline
\end{tabular}


Respondents were asked the degree to which they agreed or disagreed with statements concerning their student's perceptions of the CASE curriculum AFNR course. When given the statement, "Students enjoyed the creativity of the AFNR course lessons," $4 \%(f=1)$ disagreed, $22 \%(f=6)$ somewhat agreed, $33 \%(f=9)$ agreed, and $41 \%(f=11)$ strongly agreed (see Table 57). When given the statement, "Students enjoyed the spontaneity of the AFNR course lessons," 7\% $(f=2)$ somewhat disagreed, 37\% $(f=10)$ somewhat agreed, $33 \%(f=9)$ agreed, and $41 \%(f=11)$ strongly agreed. When given the statement, "Students enjoyed the AFNR course," 31\% $(f=8)$ somewhat agreed, $42 \%(f=$ 11) agreed, and $27 \%(f=7)$ strongly agreed. 
Table 57

Student Perceptions of CASE Creativity as Perceived by Their Teachers

\begin{tabular}{|c|c|c|c|c|c|c|c|c|c|c|c|c|c|}
\hline & \multicolumn{2}{|c|}{$\begin{array}{l}\text { Strongly } \\
\text { Disagree }\end{array}$} & \multicolumn{2}{|c|}{ Disagree } & \multicolumn{2}{|c|}{$\begin{array}{l}\text { Somewhat } \\
\text { Disagree }\end{array}$} & \multicolumn{2}{|c|}{$\begin{array}{l}\text { Somewhat } \\
\text { Agree }\end{array}$} & \multicolumn{2}{|c|}{ Agree } & \multicolumn{2}{|c|}{ Strongly Agree } & \multirow[b]{2}{*}{$n$} \\
\hline & $f$ & $\%$ & $f$ & $\%$ & $f$ & $\%$ & $f$ & $\%$ & $f$ & $\%$ & $f$ & $\%$ & \\
\hline $\begin{array}{l}\text { Students enjoyed } \\
\text { the creativity of the } \\
\text { APB course. }\end{array}$ & 0 & .00 & 1 & 3.70 & 0 & .00 & 6 & 22.22 & 9 & 33.33 & 11 & 40.74 & 27 \\
\hline $\begin{array}{l}\text { Students enjoyed } \\
\text { the spontaneity of } \\
\text { the APB course } \\
\text { lessons. }\end{array}$ & 0 & .00 & 0 & .00 & 2 & 7.41 & 10 & 37.04 & 9 & 33.33 & 6 & 22.22 & 27 \\
\hline $\begin{array}{l}\text { Students enjoyed } \\
\text { the APB course. }\end{array}$ & 0 & .00 & 0 & .00 & 0 & .00 & 8 & 30.77 & 11 & 42.31 & 7 & 26.92 & 26 \\
\hline
\end{tabular}


Respondents were asked to select a number from 1-100 to represent the level of students' positive excitement over time for the CASE curriculum APB course. For students' positive level of excitement of the beginning of the course, the mean was 56.22 and the standard deviation was 28.44 (see Table 58). For students' positive excitement in the middle of the course, the mean was 67.19 with the standard deviation of 19.82 . For students' positive excitement at the end of the course, the mean was 78.74 and the standard deviation was 15.54 .

Table 58

Students' Levels of Positive Excitement Over Time

M SD

Students' positive excitement at the beginning of the course.

56.22

Students' positive excitement in the middle of the course.

Students' positive excitement at the end of the course.

\section{Food Science and Safety (FSS)}

Respondents were asked about the training for the Food Science and Safety course. When asked about their feelings towards the training and if they felt it prepared them to implement the course, $14 \%(f=4)$ somewhat agreed, $46 \%(f=13)$ agreed, and $39 \%$ of the respondents $(f=11)$ strongly agreed (see Table 59). Respondents were asked the degree to which they agreed and disagreed that the training prepared them to use the 
lesson plans in the classroom. Of those who responded, 7\% $(f=2)$ somewhat agreed, $50 \%(f=14)$ agreed, and $43 \%(f=12)$ strongly agreed. Respondents were asked the degree to which they agreed or disagreed that the training prepared them to use the course Power Points in the classroom. Of the respondents, $4 \%(f=1)$ strongly disagree, $11 \%(f=$ 3) somewhat disagreed, $4 \%(f=1)$ disagreed, $11 \%(f=3)$ somewhat agreed, 39\% $(f=11)$ agreed, and 32\% $(f=9)$ strongly agreed. 
Table 59

CASE Training Prepared Individuals to: ${ }^{a}$

\begin{tabular}{|c|c|c|c|c|c|c|c|c|c|c|c|c|}
\hline & \multicolumn{2}{|c|}{$\begin{array}{l}\text { Strongly } \\
\text { Disagree }\end{array}$} & \multicolumn{2}{|c|}{ Disagree } & \multicolumn{2}{|c|}{$\begin{array}{l}\text { Somewhat } \\
\text { Disagree }\end{array}$} & \multicolumn{2}{|c|}{ Somewhat Agree } & \multicolumn{2}{|c|}{ Agree } & \multicolumn{2}{|c|}{ Strongly Agree } \\
\hline & $f$ & $\%$ & $f$ & $\%$ & $f$ & $\%$ & $f$ & $\%$ & $f$ & $\%$ & $f$ & $\%$ \\
\hline Implement the FSS & & & & & & & & & & & & \\
\hline CASE course & 0 & .00 & 0 & .00 & 0 & .00 & 4 & 14.29 & 13 & 46.43 & 11 & 39.29 \\
\hline $\begin{array}{l}\text { Use the CASE } \\
\text { curriculum FSS } \\
\text { course lesson plans }\end{array}$ & 0 & .00 & 0 & .00 & 0 & .00 & 2 & 7.14 & 14 & 50.00 & 12 & 42.86 \\
\hline $\begin{array}{l}\text { Use the FSS course } \\
\text { CASE Power Points } \\
\text { included in the } \\
\text { curriculum }\end{array}$ & 1 & 3.57 & 3 & 10.71 & 1 & 3.57 & 3 & 10.71 & 11 & 39.29 & 9 & 32.14 \\
\hline
\end{tabular}


Respondents were asked if they required assistance from CASE support staff in implementing the CASE course FSS in their classroom. Of those responding, 39\% $(f=$ 11) required assistance, $61 \%(f=17)$ did not (see Table 60$)$.

Table 60

Respondents Who Required Assistance from CASE When Implementing the Course in a Classroom $^{a}$

\begin{tabular}{lcc}
\hline & $f$ & $\%$ \\
\hline Yes & 11 & 39.29 \\
No & 17 & 60.71 \\
\hline
\end{tabular}

Note: ${ }^{\mathrm{a}}(n=28)$

The respondents who required assistance from CASE support staff when implementing the FSS course were given statements, and asked the extent to which they agreed or disagreed. When given the statement "I received assistance from a CASE staff member or lead teacher when implementing the CASE curriculum," $9 \%(f=1)$ disagreed, 9\% $(f=1)$ somewhat disagreed, $9 \%(f=1)$ somewhat agreed, 55\% $(f=6)$ agreed, and $18 \%(f=2)$ strongly agreed (see Table 61$)$. When given the statement, "The professional development was helpful for problems that arose over time using the curriculum," $9 \%(f$ $=1)$ disagreed, $9 \%(f=1)$ somewhat disagreed, $9 \%(f=1)$ somewhat agreed, $46 \%(f=5)$ agreed, and $27 \%(f=3)$ strongly agreed. When given the statement "The professional development aspect involved interactions through the National Association of Agricultural Educators Community of Practice Forum," 10\% $(f=1)$ disagreed, $10 \%(f=$ 1) somewhat disagreed, $10 \%(f=1)$ somewhat agreed, $30 \%(f=3)$ agreed, and $40 \%(f=$ 4) strongly agreed. 
Table 61

Aspects of Post CASE Training Assistance

\begin{tabular}{|c|c|c|c|c|c|c|c|c|c|c|c|c|c|}
\hline & \multicolumn{2}{|c|}{$\begin{array}{l}\text { Strongly } \\
\text { Disagree }\end{array}$} & \multicolumn{2}{|c|}{ Disagree } & \multicolumn{2}{|c|}{$\begin{array}{l}\text { Somewhat } \\
\text { Disagree }\end{array}$} & \multicolumn{2}{|c|}{$\begin{array}{l}\text { Somewhat } \\
\text { Agree }\end{array}$} & \multicolumn{2}{|c|}{ Agree } & \multicolumn{2}{|c|}{ Strongly Agree } & \multirow[b]{2}{*}{$n$} \\
\hline & $f$ & $\%$ & $f$ & $\%$ & $f$ & $\%$ & $f$ & $\%$ & $f$ & $\%$ & $f$ & $\%$ & \\
\hline $\begin{array}{l}\text { Received assistance } \\
\text { from a CASE staff } \\
\text { member or lead } \\
\text { teacher }\end{array}$ & 0 & .00 & 1 & 9.09 & 1 & 9.09 & 1 & 9.09 & 6 & 54.55 & 2 & 18.18 & 11 \\
\hline $\begin{array}{l}\text { Helpful for } \\
\text { problems that arose } \\
\text { over time using the } \\
\text { curriculum }\end{array}$ & 0 & .00 & 1 & 9.09 & 1 & 9.09 & 1 & 9.09 & 5 & 45.45 & 3 & 27.27 & 11 \\
\hline $\begin{array}{l}\text { Interactions through } \\
\text { the National } \\
\text { Association of } \\
\text { Agricultural } \\
\text { Educators } \\
\text { Community of } \\
\text { Practice Forum }\end{array}$ & 0 & .00 & 1 & 10.00 & 1 & 10.00 & 1 & 10.00 & 3 & 30.00 & 4 & 40.00 & 10 \\
\hline
\end{tabular}


Respondents were asked how they felt in their classrooms after the CASE training. When given the statement, "I was comfortable using the curriculum in the classroom," 21\% $(f=6)$ somewhat agreed, 46\% $(f=13)$ agreed and 32\% $(f=9)$ strongly agreed (see Table 62). When given the statement, "my knowledge and skills of the material increased from the training," 7\% $(f=2)$ somewhat agreed, 29\% $(f=8)$ agreed, and $64 \%(f=18)$ strongly agreed. When given the statement, "the training led to a positive change in their instruction," $4 \%(f=1)$ somewhat agreed, 36\% $(f=10)$ agreed, $61 \%(f=17)$ strongly agreed. When given the statement concerning their students improve learning, 46\% ( $f=13)$ agreed, and 54\% $(f=15)$ strongly agreed. 
Table 62

Post CASE Training ${ }^{a}$

\begin{tabular}{|c|c|c|c|c|c|c|c|c|c|c|c|c|}
\hline & \multicolumn{2}{|c|}{$\begin{array}{l}\text { Strongly } \\
\text { Disagree }\end{array}$} & \multicolumn{2}{|c|}{ Disagree } & \multicolumn{2}{|c|}{$\begin{array}{l}\text { Somewhat } \\
\text { Disagree }\end{array}$} & \multicolumn{2}{|c|}{ Somewhat Agree } & \multicolumn{2}{|c|}{ Agree } & \multicolumn{2}{|c|}{ Strongly Agree } \\
\hline & $f$ & $\%$ & $f$ & $\%$ & $f$ & $\%$ & $f$ & $\%$ & $f$ & $\%$ & $f$ & $\%$ \\
\hline $\begin{array}{l}\text { I was comfortable } \\
\text { using the curriculum } \\
\text { in the classroom. }\end{array}$ & 0 & .00 & 0 & .00 & 0 & .00 & 6 & 21.43 & 13 & 46.43 & 9 & 32.14 \\
\hline $\begin{array}{l}\text { My knowledge and } \\
\text { skills of the material } \\
\text { increased from the } \\
\text { training. }\end{array}$ & 0 & .00 & 0 & .00 & 0 & .00 & 2 & 7.14 & 8 & 28.57 & 18 & 64.29 \\
\hline $\begin{array}{l}\text { The training led to a } \\
\text { positive change in } \\
\text { my instruction. }\end{array}$ & 0 & .00 & 0 & .00 & 0 & .00 & 1 & 3.57 & 10 & 35.71 & 17 & 60.71 \\
\hline $\begin{array}{l}\text { My students learning } \\
\text { improved. }\end{array}$ & 0 & .00 & 0 & .00 & 0 & .00 & 0 & .00 & 13 & 46.43 & 15 & 53.57 \\
\hline
\end{tabular}

Note: ${ }^{\mathrm{a}}(n=29)$ 
Respondents were asked the extent to which they agreed or disagreed with statements concerning the CASE FSS lesson plans. When given the statement," The FSS course CASE lesson plans are user friendly to anyone who tries to use them," $11 \%(f=3)$ somewhat agreed, 54\% $(f=15)$ agreed, and 36\% $(f=10)$ strongly agreed (see Table 63). When given the statement, "The FSS course CASE lesson plans \& contain the material to be taught in each lesson," $4 \%(f=1)$ somewhat disagreed, $14 \%(f=4)$ somewhat agreed, 43\% $(f=12)$ agreed, and 39\% $(f=11)$ strongly agreed. When given the statement, "The FSS course CASE lesson plans contain the material to be taught in each unit," $4 \%(f=1)$ disagreed, 4\% ( $\mathrm{f}=1)$ somewhat disagreed, $11 \%(f=3)$ somewhat agreed, $54 \%(f=15)$ agreed, and 29\% $(f=8)$ strongly agreed. When given the statement, "The FSS course CASE lesson plans overall contain the needed amount of material," $4 \%(f=1)$ somewhat disagreed, $11 \%(f=3)$ somewhat agreed, 50\% $(f=14)$ agreed, and 36\% $(f=10)$ strongly agreed. 
Table 63

\section{CASE FSS Lesson Plans ${ }^{a}$}

\begin{tabular}{|c|c|c|c|c|c|c|c|c|c|c|c|c|}
\hline & \multicolumn{2}{|c|}{$\begin{array}{l}\text { Strongly } \\
\text { Disagree }\end{array}$} & \multicolumn{2}{|c|}{ Disagree } & \multicolumn{2}{|c|}{$\begin{array}{l}\text { Somewhat } \\
\text { Disagree }\end{array}$} & \multicolumn{2}{|c|}{ Somewhat Agree } & \multicolumn{2}{|c|}{ Agree } & \multicolumn{2}{|c|}{ Strongly Agree } \\
\hline & $f$ & $\%$ & $f$ & $\%$ & $f$ & $\%$ & $f$ & $\%$ & $f$ & $\%$ & $f$ & $\%$ \\
\hline $\begin{array}{l}\text { Plans are user } \\
\text { friendly to anyone } \\
\text { who tries to use } \\
\text { them. }\end{array}$ & 0 & .00 & 0 & .00 & 0 & .00 & 3 & 10.71 & 15 & 53.57 & 10 & 35.71 \\
\hline $\begin{array}{l}\text { Plans contain the } \\
\text { material to be taught } \\
\text { in each lesson. }\end{array}$ & 0 & .00 & 0 & .00 & 1 & 3.57 & 4 & 14.29 & 12 & 42.86 & 11 & 39.29 \\
\hline $\begin{array}{l}\text { Plans contain the } \\
\text { material to be taught } \\
\text { in each unit. }\end{array}$ & 0 & .00 & 1 & 3.57 & 1 & 3.57 & 3 & 10.71 & 15 & 53.57 & 8 & 28.57 \\
\hline $\begin{array}{l}\text { Plans overall contain } \\
\text { the needed amount of } \\
\text { material. }\end{array}$ & 0 & .00 & 0 & .00 & 1 & 3.57 & 3 & 10.71 & 14 & 50.00 & 10 & 35.71 \\
\hline
\end{tabular}

Note: ${ }^{\mathrm{a}}(n=28)$ 
Respondents were asked to what degree they agreed or disagreed with the incorporation of FFA and leadership aspects in the CASE curriculum as opposed to previous curriculums. For classroom and laboratory, $4 \%(f=1)$ agreed its incorporation was definitely inferior, $7 \%(f=2)$ agreed that its incorporation was equal to previous curriculums, $46 \%(f=12)$ agreed that its incorporation was superior and $43 \%(f=12)$ agreed that its incorporation was definitely superior (see Table 64). For FFA and leadership incorporation, 7\% $(f=2)$ agreed that CASE's incorporation was definitely inferior, $30 \%(f=8)$ agreed that it was inferior, $48 \%(f=13)$ agreed that it was equal to, $7 \%(f=2)$ agreed that it was superior, and 7\% $(f=2)$ agreed that it was definitely superior. For Supervised Agriculture Experience (SAE), 11\% $(f=3)$ agreed that CASE's incorporation was definitely inferior, $22 \%(f=12)$ agreed that the incorporation was inferior, $44 \%(f=12)$ agreed that it was equal to, $11 \%(f=3)$ agreed that it was superior, and $11 \%(f=3)$ agreed that it was definitely superior. Concerning CASE's incorporation of all aspects of an Agricultural education Program, $7 \%(f=2)$ agreed that its incorporation was definitely inferior, $30 \%(f=8)$ agreed it was equal to, $48 \%(f=13)$ agreed that it was superior, and $15 \%(f=4)$ agreed that it was definitely superior. 
Table 64

CASE Incorporation of Parts of the Agricultural Education Model ${ }^{a}$

\begin{tabular}{|c|c|c|c|c|c|c|c|c|c|c|}
\hline & \multicolumn{2}{|c|}{ Definitely Inferior } & \multicolumn{2}{|c|}{ Inferior } & \multicolumn{2}{|c|}{ Equal To } & \multicolumn{2}{|c|}{ Superior } & \multicolumn{2}{|c|}{ Definitely Superion } \\
\hline & $f$ & $\%$ & $f$ & $\%$ & $f$ & $\%$ & $f$ & $\%$ & $f$ & $\%$ \\
\hline \multicolumn{11}{|l|}{ Classroom and } \\
\hline laboratory & 1 & 3.57 & 0 & .00 & 2 & 7.14 & 13 & 46.43 & 12 & 42.86 \\
\hline FFA and leadership & 2 & 7.41 & 8 & 29.63 & 13 & 48.15 & 2 & 7.41 & 2 & 7.41 \\
\hline \multicolumn{11}{|l|}{ Supervised Agriculture } \\
\hline Experiences (SAE) & 3 & 11.11 & 6 & 22.22 & 12 & 44.44 & 3 & 11.11 & 3 & 11.11 \\
\hline \multicolumn{11}{|l|}{ All aspects of an } \\
\hline \multicolumn{11}{|l|}{ Agricultural education } \\
\hline Program & 2 & 7.41 & 0 & .00 & 8 & 29.63 & 13 & 48.15 & 4 & 14.81 \\
\hline
\end{tabular}


Respondents were asked the degree to which they agreed or disagreed with statements concerning their student's perceptions of the CASE curriculum FSS course. When given the statement, "Students enjoyed the creativity of the FSS course lessons," $11 \%(f=3)$ somewhat agreed, $50 \%(f=14)$ agreed, and $39 \%(f=11)$ strongly agreed (see Table 65). When given the statement, "Students enjoyed the spontaneity of the FSS course lessons," $4 \%(f=1)$ disagreed, $14 \%(f=4)$ somewhat agreed, $43 \%(f=12)$ agreed, and $39 \%(f=11)$ strongly agreed. When given the statement, "Students enjoyed the FSS course," $7 \%(f=2)$ somewhat agreed, 50\% $(f=14)$ agreed, and 43\% $(f=12)$ strongly agreed. 
Table 65

Student Perceptions of CASE Creativity as Perceived by Their Teachers ${ }^{a}$

\begin{tabular}{|c|c|c|c|c|c|c|c|c|c|c|c|c|}
\hline & \multicolumn{2}{|c|}{$\begin{array}{l}\text { Strongly } \\
\text { Disagree }\end{array}$} & \multicolumn{2}{|c|}{ Disagree } & \multicolumn{2}{|c|}{$\begin{array}{l}\text { Somewhat } \\
\text { Disagree }\end{array}$} & \multicolumn{2}{|c|}{ Somewhat Agree } & \multicolumn{2}{|c|}{ Agree } & \multicolumn{2}{|c|}{ Strongly Agree } \\
\hline & $f$ & $\%$ & $f$ & $\%$ & $f$ & $\%$ & $f$ & $\%$ & $f$ & $\%$ & $f$ & $\%$ \\
\hline $\begin{array}{l}\text { Students enjoyed the } \\
\text { creativity of the FSS } \\
\text { course lessons. }\end{array}$ & 0 & .00 & 0 & .00 & 0 & .00 & 3 & 10.71 & 14 & 50.00 & 11 & 39.29 \\
\hline $\begin{array}{l}\text { Students enjoyed the } \\
\text { spontaneity of the }\end{array}$ & & & & & & & & & & & & \\
\hline FSS course lessons. & 0 & .00 & 1 & 3.57 & 0 & .00 & 4 & 14.29 & 12 & 42.86 & 11 & 39.29 \\
\hline $\begin{array}{l}\text { Students enjoyed the } \\
\text { FSS course. }\end{array}$ & 0 & .00 & 0 & .00 & 0 & .00 & 2 & 7.14 & 14 & 50.00 & 12 & 42.86 \\
\hline
\end{tabular}

Note: ${ }^{\mathrm{a}}(n=28)$ 
Respondents were asked to select a number from 1-100 to represent the level of students' positive excitement over time for the CASE curriculum FSS course. For students' positive level of excitement of the beginning of the course, the mean was 67.07 and the standard deviation was 24.99 (see Table 66). For students' positive excitement in the middle of the course, the mean was 70.21 with the standard deviation of 18.72 . For students' positive excitement at the end of the course, the mean was 84.08 and the standard deviation was 13.92 .

Table 66

Students' Levels of Positive Excitement Over Time

M SD

Students' positive excitement at the beginning of the course.

Students' positive excitement in the middle of the course.

Students' positive excitement at the end of the course.

\section{Agricultural Research and Development (ARD)}

Respondents were asked about the training for the Agricultural Power and Technology course. When asked about their feelings towards the training and if they felt it prepared them to implement the course, $9 \%(f=1)$ somewhat disagreed, $27 \%(f=3)$ somewhat agreed, $27 \%(f=3)$ agreed, and $36 \%$ of the respondents $(f=4)$ strongly agreed (see Table 67). Respondents were asked the degree to which they agreed and disagreed 
that the training prepared them to use the lesson plans in the classroom. Of those who responded, 20\% $(f=2)$ somewhat agreed, $60 \%(f=2)$ agreed, and $20 \%(f=2)$ strongly agreed. Respondents were asked the degree to which they agreed or disagreed that the training prepared them to use the course Power Points in the classroom. Of the respondents, $9 \%(f=1)$ somewhat disagreed, $18 \%(f=2)$ somewhat agreed, $46 \%(f=5)$ agreed, and $27 \%(f=3)$ strongly agreed. 
Table 67

CASE Training Prepared Individuals to:

\begin{tabular}{|c|c|c|c|c|c|c|c|c|c|c|c|c|c|}
\hline & \multicolumn{2}{|c|}{$\begin{array}{l}\text { Strongly } \\
\text { Disagree }\end{array}$} & \multicolumn{2}{|c|}{ Disagree } & \multicolumn{2}{|c|}{$\begin{array}{l}\text { Somewhat } \\
\text { Disagree }\end{array}$} & \multicolumn{2}{|c|}{$\begin{array}{l}\text { Somewhat } \\
\text { Agree }\end{array}$} & \multicolumn{2}{|c|}{ Agree } & \multicolumn{2}{|c|}{ Strongly Agree } & \multirow[b]{2}{*}{$n$} \\
\hline & $f$ & $\%$ & $f$ & $\%$ & $f$ & $\%$ & $f$ & $\%$ & $f$ & $\%$ & $f$ & $\%$ & \\
\hline $\begin{array}{l}\text { Implement the } \\
\text { ARD CASE course }\end{array}$ & 0 & .00 & 0 & .00 & 1 & 9.09 & 3 & 27.27 & 3 & 27.27 & 4 & 36.36 & 11 \\
\hline $\begin{array}{l}\text { Use the CASE } \\
\text { curriculum ARD } \\
\text { course lesson plans }\end{array}$ & 0 & .00 & 0 & .00 & 0 & .00 & 2 & 20.00 & 6 & 60.00 & 2 & 20.00 & 10 \\
\hline $\begin{array}{l}\text { Use the ARD } \\
\text { course CASE } \\
\text { Power Points } \\
\text { included in the } \\
\text { curriculum }\end{array}$ & 0 & .00 & 0 & .00 & 1 & 9.09 & 2 & 18.18 & 5 & 45.45 & 3 & 27.27 & 11 \\
\hline
\end{tabular}


Respondents were asked if they required assistance from CASE support staff in implementing the CASE course ARD in their classroom. Of those responding, $27 \%(f=$ 3) required assistance, $73 \%(f=8)$ did not (see Table 68).

Table 68

Respondents Who Required Assistance from CASE When Implementing the Course in a Classroom $^{a}$

\begin{tabular}{lcc}
\hline & $\mathrm{f}$ & $\%$ \\
\hline Yes & 3 & 27.27 \\
No & 8 & 72.73 \\
\hline
\end{tabular}

Note: ${ }^{\mathrm{a}}(n=11)$

The respondents who required assistance from CASE support staff when implementing the ARD course were given statements, and asked the extent to which they agreed or disagreed. When given the statement "I received assistance from a CASE staff member or lead teacher when implementing the CASE curriculum," $9 \%(f=1)$ somewhat disagreed, $27 \%(f=3)$ somewhat agreed, $27 \%(f=3)$ agreed, and 36\% $(f=4)$ strongly agreed (see Table 69). When given the statement, "The professional development was helpful for problems that arose over time using the curriculum," $20 \%(f=2)$ somewhat agreed, $60 \%(f=6)$ agreed, and 20\% $(f=2)$ strongly agreed. When given the statement “The professional development aspect involved interactions through the National Association of Agricultural Educators Community of Practice Forum," 9\% $(f=1)$ somewhat disagreed, $18 \%(f=2)$ somewhat agreed, $46 \%(f=3)$ agreed, and $27 \%(f=5)$ strongly agreed. 
Table 69

Aspects of Post CASE Training Assistance ${ }^{a}$

\begin{tabular}{|c|c|c|c|c|c|c|c|c|c|c|c|c|}
\hline & \multicolumn{2}{|c|}{$\begin{array}{l}\text { Strongly } \\
\text { Disagree }\end{array}$} & \multicolumn{2}{|c|}{ Disagree } & \multicolumn{2}{|c|}{$\begin{array}{l}\text { Somewhat } \\
\text { Disagree }\end{array}$} & \multicolumn{2}{|c|}{ Somewhat Agree } & \multicolumn{2}{|c|}{ Agree } & \multicolumn{2}{|c|}{ Strongly Agree } \\
\hline & $f$ & $\%$ & $f$ & $\%$ & $f$ & $\%$ & $f$ & $\%$ & $f$ & $\%$ & $f$ & $\%$ \\
\hline $\begin{array}{l}\text { Received assistance } \\
\text { from a CASE staff } \\
\text { member or lead } \\
\text { teacher }\end{array}$ & 0 & .00 & 0 & .00 & 0 & .00 & 0 & .00 & 2 & 66.67 & 1 & 33.33 \\
\hline $\begin{array}{l}\text { Helpful for problems } \\
\text { that arose over time } \\
\text { using the curriculum }\end{array}$ & 0 & .00 & 0 & .00 & 0 & .00 & 1 & 33.33 & 2 & 66.67 & 0 & .00 \\
\hline $\begin{array}{l}\text { Interactions through } \\
\text { the National } \\
\text { Association of } \\
\text { Agricultural } \\
\text { Educators } \\
\text { Community of } \\
\text { Practice Forum }\end{array}$ & 0 & .00 & 1 & 33.33 & 0 & .00 & 0 & .00 & 2 & 66.67 & 0 & .00 \\
\hline
\end{tabular}

Note: ${ }^{\text {a }}(n=3)$ 
Respondents were asked how they felt in their classrooms after the CASE training. When given the statement, "I was comfortable using the curriculum in the classroom," 9\% $(f=1)$ disagreed, 18\% $(f=2)$ somewhat agreed, 46\% $(f=5)$ agreed and $27 \%(f=133)$ strongly agreed (see Table 70$)$. When given the statement, "my knowledge and skills of the material increased from the training," 27\% $(f=3)$ somewhat agreed, $27 \%$ $(f=3)$ agreed, and $46 \%(f=5)$ strongly agreed. When given the statement, "the training led to a positive change in their instruction," $9 \%(f=1)$ disagreed, $9 \%(f=1)$ somewhat disagreed, $55 \%(f=6)$ agreed, and $27 \%(f=3)$ strongly agreed. When given the statement concerning their students improve learning, $10 \%(f=1)$ strongly disagreed, $10 \%(f=1)$ somewhat agreed, $40 \%(f=4)$ agreed, and $40 \%(f=4)$ strongly agreed. 
Table 70

\section{Post CASE Training}

\begin{tabular}{|c|c|c|c|c|c|c|c|c|c|c|c|c|c|}
\hline & \multicolumn{2}{|c|}{$\begin{array}{l}\text { Strongly } \\
\text { Disagree }\end{array}$} & \multicolumn{2}{|c|}{ Disagree } & \multicolumn{2}{|c|}{$\begin{array}{l}\text { Somewhat } \\
\text { Disagree }\end{array}$} & \multicolumn{2}{|c|}{$\begin{array}{l}\text { Somewhat } \\
\text { Agree }\end{array}$} & \multicolumn{2}{|c|}{ Agree } & \multicolumn{2}{|c|}{ Strongly Agree } & \multirow[b]{2}{*}{$n$} \\
\hline & $f$ & $\%$ & $f$ & $\%$ & $f$ & $\%$ & $f$ & $\%$ & $f$ & $\%$ & $f$ & $\%$ & \\
\hline $\begin{array}{l}\text { I was comfortable } \\
\text { using the } \\
\text { curriculum in the } \\
\text { classroom. }\end{array}$ & 0 & .00 & 1 & 9.09 & 0 & .00 & 2 & 18.18 & 5 & 45.45 & 3 & 27.27 & 11 \\
\hline $\begin{array}{l}\text { My knowledge and } \\
\text { skills of the } \\
\text { material increased } \\
\text { from the training. }\end{array}$ & 0 & .00 & 0 & .00 & 0 & .00 & 3 & 27.27 & 3 & 27.27 & 5 & 45.45 & 11 \\
\hline $\begin{array}{l}\text { The training led to } \\
\text { a positive change in } \\
\text { my instruction. }\end{array}$ & 0 & .00 & 1 & 9.09 & 1 & 9.09 & 0 & .00 & 6 & 54.55 & 3 & 27.27 & 11 \\
\hline $\begin{array}{l}\text { My students } \\
\text { learning improved. }\end{array}$ & 1 & 10.00 & 0 & .00 & 0 & .00 & 1 & 10.00 & 4 & 40.00 & 4 & 40.00 & 10 \\
\hline
\end{tabular}


Respondents were asked the extent to which they agreed or disagreed with statements concerning the CASE ARD lesson plans. When given the statement," The ARD course CASE lesson plans are user friendly to anyone who tries to use them," $36 \%$ $(f=4)$ somewhat agreed, $46 \%(f=5)$ agreed, and 18\% $(f=2)$ strongly agreed (see Table 71). When given the statement, "The ARD course CASE lesson plans \& contain the material to be taught in each lesson," $9 \%(f=1)$ strongly disagreed, $9 \%(f=1)$ disagreed, $18 \%(f=2)$ somewhat agreed, $36 \%(f=4)$ agreed, and $27 \%(f=3)$ strongly agreed. When given the statement, "The ARD course CASE lesson plans contain the material to be taught in each unit," $9 \%(f=1)$ strongly disagreed, $9 \%(f=1)$ disagreed, $27 \%(f=3)$ somewhat agreed, $27 \%(f=3)$ agreed, and 36\% $(f=4)$ strongly agreed. When given the statement, "The ARD course CASE lesson plans overall contain the needed amount of material," $9 \%(f=1)$ strongly disagreed, $9 \%(f=1)$ disagreed, $18 \%(f=2)$ somewhat agreed, $27 \%(f=3)$ agreed, and 36\% $(f=4)$ strongly agreed. 
Table 71

\section{CASE ARD Lesson Plans ${ }^{a}$}

\begin{tabular}{|c|c|c|c|c|c|c|c|c|c|c|c|c|}
\hline & \multicolumn{2}{|c|}{$\begin{array}{l}\text { Strongly } \\
\text { Disagree }\end{array}$} & \multicolumn{2}{|c|}{ Disagree } & \multicolumn{2}{|c|}{$\begin{array}{l}\text { Somewhat } \\
\text { Disagree }\end{array}$} & \multicolumn{2}{|c|}{ Somewhat Agree } & \multicolumn{2}{|c|}{ Agree } & \multicolumn{2}{|c|}{ Strongly Agree } \\
\hline & $f$ & $\%$ & $f$ & $\%$ & $f$ & $\%$ & $f$ & $\%$ & $f$ & $\%$ & $f$ & $\%$ \\
\hline $\begin{array}{l}\text { Plans are user } \\
\text { friendly to anyone } \\
\text { who tries to use } \\
\text { them. }\end{array}$ & 0 & .00 & 0 & .00 & 0 & .00 & 4 & 36.36 & 5 & 45.45 & 2 & 18.18 \\
\hline $\begin{array}{l}\text { Plans contain the } \\
\text { material to be taught } \\
\text { in each lesson. }\end{array}$ & 1 & 9.09 & 1 & 9.09 & 0 & .00 & 2 & 18.18 & 4 & 36.36 & 3 & 27.27 \\
\hline $\begin{array}{l}\text { Plans contain the } \\
\text { material to be taught } \\
\text { in each unit. }\end{array}$ & 1 & 9.09 & 0 & .00 & 0 & .00 & 3 & 27.27 & 3 & 27.27 & 4 & 36.36 \\
\hline $\begin{array}{l}\text { Plans overall contain } \\
\text { the needed amount of } \\
\text { material. }\end{array}$ & 1 & 9.09 & 1 & 9.09 & 0 & .00 & 2 & 18.18 & 3 & 27.27 & 4 & 36.36 \\
\hline
\end{tabular}

Note: ${ }^{\mathrm{a}}(n=11)$ 
Respondents were asked to what degree they agreed or disagreed with the incorporation of FFA and leadership aspects in the CASE curriculum as opposed to previous curriculums. For classroom and laboratory, $10 \%(f=1)$ agreed that its incorporation is definitely inferior, $20 \%(f=2)$ agreed that its incorporation was equal to previous curriculums, $40 \%(f=4)$ agreed that its incorporation was superior and $30 \%(f=$ 3) agreed that its incorporation was definitely superior (see Table 72). For FFA and leadership incorporation, $11 \%(f=1)$ agreed that CASE's incorporation was definitely inferior, $22 \%(f=2)$ agreed that it was inferior, $22 \%(f=2)$ agreed that it was equal to, $33 \%(f=3)$ agreed that it was superior, and $11 \%(f=1)$ agreed that it was definitely superior. For Supervised Agriculture Experience (SAE), 33\% $(f=3)$ agreed that the incorporation was inferior, $22 \%(f=2)$ agreed that it was equal to, $33 \%(f=3)$ agreed that it was superior, and $11 \%(f=1)$ agreed that it was definitely superior. Concerning CASE's incorporation of all aspects of an Agricultural education Program, 11\% $(f=1)$ agreed that its incorporation was definitely inferior, $11 \%(f=1)$ agreed that it was inferior, $11 \%(f=1)$ agreed it was equal to, $44 \%(f=4)$ agreed that it was superior, and $22 \%(f=2)$ agreed that it was definitely superior. 
Table 72

CASE Incorporation of Parts of the Agricultural Education Model

\begin{tabular}{|c|c|c|c|c|c|c|c|c|c|c|c|}
\hline & \multicolumn{2}{|c|}{ Definitely Inferior } & \multicolumn{2}{|c|}{ Inferior } & \multicolumn{2}{|c|}{ Equal To } & \multicolumn{2}{|c|}{ Superior } & \multicolumn{2}{|c|}{$\begin{array}{l}\text { Definitely } \\
\text { Superior }\end{array}$} & \multirow[b]{2}{*}{$n$} \\
\hline & $f$ & $\%$ & $f$ & $\%$ & $f$ & $\%$ & $f$ & $\%$ & $f$ & $\%$ & \\
\hline $\begin{array}{l}\text { Classroom and } \\
\text { laboratory }\end{array}$ & 1 & 10.00 & 0 & .00 & 2 & 20.00 & 4 & 40.00 & 3 & 30.00 & 10 \\
\hline FFA and leadership & 1 & 11.11 & 2 & 22.22 & 2 & 22.22 & 3 & 33.33 & 1 & 11.11 & 9 \\
\hline $\begin{array}{l}\text { Supervised Agriculture } \\
\text { Experiences (SAE) }\end{array}$ & 0 & .00 & 3 & 33.33 & 2 & 22.22 & 3 & 33.33 & 1 & 11.11 & 9 \\
\hline $\begin{array}{l}\text { All aspects of an } \\
\text { Agricultural education } \\
\text { Program }\end{array}$ & 1 & 11.11 & 1 & 11.11 & 1 & 11.11 & 4 & 44.44 & 2 & 22.22 & 9 \\
\hline
\end{tabular}


Respondents were asked the degree to which they agreed or disagreed with statements concerning their student's perceptions of the CASE curriculum ARD course. When given the statement, "Students enjoyed the creativity of the ARD course lessons," $9 \%(f=1)$ strongly disagreed, $9 \%(f=1)$ somewhat disagreed, $27 \%(f=3)$ somewhat agreed, 36\% $(f=4)$ agreed, and 18\% $(f=2)$ strongly agreed (see Table 73). When given the statement, "Students enjoyed the spontaneity of the ARD course lessons," $9 \%(f=1)$ strongly disagreed, $18 \%(f=2)$ somewhat disagreed, $36 \%(f=4)$ somewhat agreed, $18 \%$ $(f=2)$ agreed, and $18 \%(f=2)$ strongly agreed. When given the statement, "Students enjoyed the ARD course," 9\% $(f=1)$ strongly disagreed, 18\% $(f=2)$ somewhat disagreed, $27 \%(f=3)$ somewhat agreed, $27 \%(f=3)$ agreed, and 18\% $(f=2)$ strongly agreed. 
Table 73

Student Perception of CASE Creativity as Perceived by Their Teachers ${ }^{a}$

\begin{tabular}{|c|c|c|c|c|c|c|c|c|c|c|c|c|}
\hline & \multicolumn{2}{|c|}{$\begin{array}{l}\text { Strongly } \\
\text { Disagree }\end{array}$} & \multicolumn{2}{|c|}{ Disagree } & \multicolumn{2}{|c|}{$\begin{array}{l}\text { Somewhat } \\
\text { Disagree }\end{array}$} & \multicolumn{2}{|c|}{ Somewhat Agree } & \multicolumn{2}{|c|}{ Agree } & \multicolumn{2}{|c|}{ Strongly Agree } \\
\hline & $f$ & $\%$ & $f$ & $\%$ & $f$ & $\%$ & $f$ & $\%$ & $f$ & $\%$ & $f$ & $\%$ \\
\hline $\begin{array}{l}\text { Students enjoyed the } \\
\text { creativity of the ARD } \\
\text { course lessons. }\end{array}$ & 1 & 9.09 & 0 & .00 & 1 & 9.09 & 3 & 27.27 & 4 & 36.36 & 2 & 18.18 \\
\hline $\begin{array}{l}\text { Students enjoyed the } \\
\text { spontaneity of the }\end{array}$ & & & & & & & & & & & & \\
\hline ARD course lessons. & 1 & 9.09 & 0 & .00 & 2 & 18.18 & 4 & 36.36 & 2 & 18.18 & 2 & 18.18 \\
\hline $\begin{array}{l}\text { Students enjoyed the } \\
\text { ARD course. }\end{array}$ & 1 & 9.09 & 0 & .00 & 2 & 18.18 & 3 & 27.27 & 3 & 27.27 & 2 & 18.18 \\
\hline
\end{tabular}

Note: ${ }^{\mathrm{a}}(n=11)$ 
Respondents were asked to select a number from 1-100 to represent the level of students' positive excitement over time for the CASE curriculum ARD course. For students' positive level of excitement of the beginning of the course, the mean was 64.45 and the standard deviation was 28.69 (see Table 74). For students' positive excitement in the middle of the course, the mean was 63.55 with the standard deviation of 23.11 . For students' positive excitement at the end of the course, the mean was 66.44 and the standard deviation was 29.72 .

Table 74

Students' Levels of Positive Excitement Over Time

M SD

Students' positive excitement at the beginning of the course.

Students' positive excitement in the middle of the course.

Students' positive excitement at the end of the course. 


\section{CHAPTER V}

\section{Conclusions and Recommendations}

\section{Purpose of the Study}

The purpose of this study was to provide information about the attitudes and perceptions of agricultural educators that have or currently use the CASE curriculum in their classrooms and have completed the CASE professional development. This study also focused on the connection between professional development and classroom and laboratory instruction. The core aspects of professional development which transition from teachers' experiences with development to teaching in the classroom. The following objectives directed this study.

\section{Objectives}

1. To determine the perceptions of educators using the CASE curriculum related to the lesson plans, materials and courses in the curriculum.

2. To determine the perceptions of educators about the CASE curriculum training.

3. To determine the perceptions of educators on the CASE curriculum as it relates to the total agricultural education model.

4. To determine the perceptions and attitudes of students' views of the CASE curriculum as perceived by their teachers.

\section{Summary of Findings}

The population consisted of all agricultural educators who have completed the CASE institute training and currently teach in a school based high school agriculture 
classroom. Individuals who have completed the CASE institute training who currently teach at the collegiate level, any individuals who worked for CASE and educators who had been through the training but left no contact information were excluded. The end population for this study was 1,028 individuals. The final response rate for the study was over half the population (52\%).

The respondents were asked to identify their demographical information. Over half the respondents identified as females. The majority of the respondents were white. Over half the respondents had a Master's Degree as their highest level of education.

When asked questions about the CASE curriculum, the majority of the respondents have been using CASE for ( 2 years, 3 years or less than 1 year). The majority of respondents were currently using CASE curriculum in their classrooms. The largest amount of respondents were trained in the Introduction to Agriculture, Food and Natural Resources course, Principles of Agriculture Science- Animal and Principles of Agriculture Science- Plant courses.

\section{Introduction to Agriculture, Food and Natural Resources (AFNR).}

The training for the AFNR course was highly rated by the respondents. Almost all of the respondents agreed or strongly agreed that the training prepared them to implement the AFNR course, use the lesson plans and PowerPoints. Over three quarters of the respondents did not require assistance when implementing the course in the classroom. Of those respondents who did require assistance, a large amount received assistance from a CASE lead teacher, had help when problems arose or used the National Association of Agricultural educators Community of Practice Forum for assistance. Following the CASE training, almost all of the respondents agreed to some level that they were 
comfortable using the curriculum in the classroom. They also agreed their knowledge and skills improved from the training which lead to a positive change in their teaching. Almost all respondents agreed their students' learning improved.

When asked about aspects of the curriculum, nearly three quarters of the respondents agreed or strongly agreed the lesson plans are user friendly to anyone who tries to use them. Over three quarters of the respondents agreed or strongly agreed that the lesson plans contain the appropriate materials to be taught in each lesson, unit, and overall. The respondents were questioned about the incorporation of the parts of the agricultural education model, classroom and laboratory, FFA and SAE, in the CASE curriculum. Respondents agreed the incorporation for classroom and laboratory and FFA and leadership were equal to to definitely superior to previous curriculums. One third of the respondents agreed that CASE's incorporation of SAEs was inferior or definitely inferior to previous curriculums. All aspects of the agricultural education model were equal to or definitely superior for the majority of the respondents.

Teachers were asked about their perceptions on their students attitudes towards the course and curriculum. Almost all somewhat agreed to strongly agreed their students enjoyed the creativity and spontaneity of the AFNR course. Teachers were asked to rate their students level of positive excitement on a scale from 1-100. The average mean was 66.90 with a standard deviation of 20.85 .

\section{Principles of Agricultural Science- Animal (ASA).}

Respondents were questioned about the training for the ASA course. The training was well received among respondents. Over three quarters of all the respondents somewhat agreed to strongly agreed that the training prepared individuals to implement 
the ASA course, use the lesson plans and PowerPoints. Only one quarter of the respondents needed assistance implementing the course in the classroom. Of those respondents, over three quarters somewhat agreed to strongly agreed they received assistance from a CASE lead teacher and had help when problems arose when implementing the course. A majority of the respondents also agreed that they had help through the National Association of Agricultural Educators Community Practice Forum. After the training, almost all respondents somewhat agreed to strongly agreed they were comfortable using the curriculum, their knowledge and skills improved, and the training lead to a positive change in their teaching. Over three quarters of the population also felt their students' learning improved as a result.

Respondents were asked about different aspects of the CASE curriculum. Almost all the respondents somewhat agreed to strongly agreed the ASA lesson plans were user friendly and contained the sufficient amount of information for each lesson and unit. CASE's incorporation of the parts of the agricultural education model was also evaluated. Almost all of the respondents agreed that classroom and laboratory incorporation was equal to, superior to or definitely superior previous curriculums. For FFA and leadership and SAEs, three quarters of the respondents agreed the incorporation was definitely inferior or to equal to previous curriculums. Overall, almost all rated the curriculum as equal to or above for the incorporation of all aspects of the agricultural education model.

Respondents were asked about their perceptions of their students attitudes toward the ASA course. When asked about the creativity and spontaneity of the course lessons, over three quarters of the respondents agreed their students enjoyed those aspects of the course and it overall. Teachers were also asked to measure their student's positive level 
of excitement levels from 1-100. The average mean was 69.15 with a standard deviation of 20.15 .

\section{Principles of Agricultural Science- Plant (ASP).}

Respondents were questioned about the CASE training for the ASP course. All the respondents rated the training well and somewhat agreed to strongly agreed the training prepared them to implement the course, use the lesson plans and PowerPoints. Only one quarter of respondents required assistance after the training when implementing the course in the classroom. Of the respondents who did require assistance, over three quarters received assistance from a lead teacher or CASE staff member. A majority of the respondents, over three quarters, received help when problems arose over time and used the National Association of Agricultural Educators Community of Practice Forum. After the CASE training, almost all respondents somewhat agreed to strongly agreed that they felt comfortable using the curriculum, their knowledge and skills increased and the training led to a positive change in their instruction. Overall, over three quarters of respondents felt their student's learning improved.

Respondents were asked about different parts of the ASP course. Over three quarters of the respondents somewhat agreed to strongly agreed the lesson plans were user friendly to anyone who tries to use them. Respondents also somewhat agreed to strongly agreed that the lesson plans contain all the material for each lesson and unit. Respondents were also questioned about CASE's incorporation of the parts of the agricultural education model. Almost all respondents agreed the incorporation of classroom and laboratory was equal to, superior, or definitely superior. FFA and leaderships incorporation was rated by over three quarters of respondents as definitely 
inferior, inferior or equal to previous curriculums. SAE incorporation was rated equal to or above by three quarters of the respondents. Overall, the incorporation of all aspects of the agricultural education program was rated equal to or above by over three quarters of the respondents.

Teachers were asked their perceptions of their student's attitudes towards the ASP course creativity. The greater majority of the respondents somewhat agreed to strongly agreed their students enjoyed the creativity and spontaneity of the lessons. Respondents were asked to rate their student's level of positive excitement throughout the year on a scale from 1-100. The average mean was 65.21 with a standard deviation of 21.62.

\section{Agricultural Power and Technology (APT).}

Respondents were asked about parts of the CASE training. All respondents somewhat agreed, agreed, or strongly agreed the CASE training prepared them to implement the course, lesson plans and PowerPoints. Almost all the respondents did not require assistance when implementing the course in the classroom. Of the few respondents that did require assistance, all strongly disagreed they received assistance from a CASE staff member or lead teacher. All respondents strongly agreed they did receive help when problems arose and utilized the National Association of Agricultural Educators Community of Practice Forum. After the training, all respondents somewhat agreed to strongly agreed they were comfortable using the curriculum in the classroom, their knowledge and skills increased and there was a positive change in their instruction. Respondents also agreed that their learning improved.

Respondents were questioned about the parts of the APT course. Almost all of the respondents somewhat agreed to strongly agreed the lesson plans were user friendly to 
anyone who tries to use them. Respondents also agreed the lesson plans contained the appropriate amount of material for each lesson and unit. The parts of the agricultural education model were evaluated for the APT course. Classroom and laboratory incorporation was rated as equal to, superior or definitely superior to previous curriculums. FFA and leadership, and SAE incorporation was rated from definitely inferior to equal to by the majority of the respondents compared to previous curriculums.

Teachers were asked about their students perceptions about the creativity of the APT lessons. The majority of the respondents somewhat agreed, agreed or definitely agreed their students enjoyed the lessons, their creativity and spontaneity. Respondents were also asked to rate their students level of positive excitement throughout the year on a scale from 1-100. The average mean was 57.34 with a standard deviation of 24.86 .

\section{Natural Resources and Ecology (NRE).}

Respondents were asked about different parts of the CASE NRE course training. Almost all respondents somewhat agreed, agreed or strongly agreed the training prepared them to use the NRE course in the classroom, and they were prepared to use the lesson plans and PowerPoints. Over three quarters of the respondents did not require assistance when implementing the course in a classroom. Of those respondents that did require assistance, all somewhat agreed to strongly agreed they received assistance from a CASE lead teacher or staff member when problems arose. All respondents also agreed or strongly agreed the professional development aspect was helpful for problems that arose over time, and they had interactions through the National Association of Agricultural Educators Community of Practice Forum. After the training, all respondents somewhat agreed to strongly agreed they felt comfortable using the curriculum in the classroom. 
Over three quarters of the respondents somewhat agreed to strongly agreed that their knowledge and skills increased from the training, and it lead to a positive change in their teaching. All respondents agreed their students learning improved as a result.

Respondents were asked to evaluate parts of the NRE course curriculum. Almost all of the respondents somewhat agreed to strongly agreed the lesson plans were user friendly to anyone who tries to use them. They also agreed the lesson plans contained the material to be taught in each lesson, unit and overall. Respondents were asked about the incorporation of the parts of the agricultural education model. All respondents agreed the incorporation of classroom and laboratory was equal to, superior, or definitely superior to previous curriculums. Over three quarters of respondents agreed the incorporation of FFA and leadership incorporation was definitely inferior, inferior or equal to previous curriculums. The majority of respondents agreed that the incorporation of SAEs, and all aspects of an agricultural education program was equal to, superior or definitely superior to previous curriculums.

Teachers were asked to evaluate their perceptions of their student's attitudes towards the NRE course. Nearly all of the respondents somewhat agreed to strongly agreed their students enjoyed the creativity and spontaneity of the NRE course lessons. Respondents were also asked to rate their student's level of positive excitement over time on a scale from 1-100. The average mean was 62.87 with a standard deviation of 21.34 .

\section{Animal and Plant Biotechnology (APB).}

Respondents were asked to evaluate the CASE course training for the APB course. Over three quarters of respondents somewhat agreed, agreed or strongly agreed the training prepared them to implement the APB course. All respondents agreed the 
training prepared them to use the lesson plans, and the majority of respondents somewhat agreed to strongly agreed that the training prepared them to use the PowerPoints. Over half the respondents required assistance when implementing the course in the classroom. Three quarters of those respondents somewhat agreed to strongly agreed they received assistance from a staff member or lead teacher when implementing the course, or received help whenever problems arose over time. All respondents agreed they interacted with others using the National Association of Agricultural Educators Community of Practice Forum. After the training, over three quarters of respondents somewhat agreed to strongly agreed they were comfortable using the curriculum in the classroom and the training led to a positive change in their instruction. All of the respondents somewhat agreed to strongly agreed that their knowledge and skills improved from the training and their students learning improved.

Respondents were asked about specific parts of the course curriculum. Over three quarters of the respondents somewhat agreed to strongly agreed the lesson plans were user friendly to anyone who tries to use them. Almost all respondents somewhat agreed to strongly agreed the lesson plans contain the appropriate material to be taught in each lesson, each unit and overall. When asked to evaluate the curriculums incorporation of the parts of the agricultural education model, all respondents agreed that the incorporation of classroom and laboratory was equal to, superior or definitely superior to previous curriculums. Over three quarters of respondents agreed that the incorporation of FFA and leadership and SAEs was equal to, superior or definitely superior previous curriculums. Overall, almost all agreed that all aspects of an agricultural education 
program were incorporated equal to, superior or definitely superior to previous curriculums.

Respondents were asked their perceptions of their students' views toward the APB course. When asked about their students views on the creativity of the lessons, almost all somewhat agreed to strongly agreed their student's enjoyed the creativity of the course. Over three quarters of the respondents somewhat agreed to strongly agreed their students enjoyed the spontaneity of the lesson and enjoyed the course overall. Teachers were also asked to evaluate their student's levels of positive excitement over time on scale from 1-100. The average mean was 67.38 with a standard deviation of 21.27 .

\section{Food Science and Safety (FSS).}

Respondents were asked their views on the CASE FSS course training. All respondents somewhat agreed, agreed or strongly agreed that the training prepared them to implement the FSS course, and use the lesson plans. Over three quarters of respondents somewhat agreed to strongly agreed the training prepared them to use the PowerPoints. Over half of the respondents did not require assistance implementing the course in a classroom. Of the respondents, a little under half, that did require assistance three quarters somewhat agreed to agreed they received assistance from a staff member or CASE lead teacher when implementing the course. Over three quarters of respondents also somewhat agreed to strongly agreed the professional development was helpful for when problems arose and they used the National Association of Agricultural Educators Community Practice Forum. After the CASE training, all respondents somewhat agreed to strongly agreed that they were comfortable using the course curriculum, and their 
knowledge and skills improved from the training. All respondents also somewhat agreed to strongly agreed the training led to a positive change in their teaching and their students learning improved.

Respondents were asked about certain parts of the FSS course curriculum. All respondents somewhat agreed to strongly agreed the lesson plans were user friendly to anyone who tries to use them. Almost all respondents also somewhat agreed to strongly agreed the plans contained the appropriate amount of material for each lesson, unit and overall. Respondents were asked about the incorporation of parts of the agricultural education model in the course. Classroom and laboratory had over three quarters of the respondents that agreed that its incorporation was equal to, superior or definitely superior to previous curriculums. Over three quarters of the respondents agreed that FFA and leadership and SAE incorporation was definitely inferior, inferior or equal to previous curriculums. Over three quarters agreed the FSS course had the incorporation of all parts of an agricultural education program.

Teachers were asked to evaluate their student's attitudes towards the FSS course. All respondents somewhat agreed to strongly agreed their students enjoyed the creativity of the FSS course and the course overall. Almost all respondents agreed their students enjoyed the spontaneity of the course lessons. Respondents were asked to evaluate their student's level of positive excitement of the FSS course overtime on a scale from 1-100. The average mean was 74.12 with a standard deviation of 19.21 .

\section{Agricultural Research and Development (ARD).}

Respondents were asked about the training for the ARD CASE course. Almost all of the respondents somewhat agreed, agreed, or strongly agreed the training prepared 
them to use the curriculum in the classroom. All respondents somewhat agreed to strongly agreed the training prepared them to use the lesson plans. Almost all respondents somewhat agreed to strongly agreed the training prepared them to use the PowerPoints. Over half the population did not require assistance implementing the course in the classroom. Of the respondents that did require assistance, all of them agreed or strongly agreed that they received help from a lead teacher or staff member when implementing the course and had help over time as problems arose. Over half of the respondents agreed they used the National Association of Agricultural Educators Community of Practice Forum over time when implementing the course. After the training, respondents all agreed their knowledge and skills improved from the training. Almost all of the respondents felt comfortable using the curriculum in the classroom, and agreed the training lead to an improvement in their teaching. Over half of the respondents somewhat agreed to strongly agreed their students learning improved.

Respondents were asked about specific parts of the ARD course curriculum. All of the respondents somewhat agreed to strongly agreed the lesson plans are user friendly to anyone who tries to use them. The majority of the respondents somewhat agreed to strongly agreed the lesson plans contained the appropriate amount of information for each lesson, unit and overall. Respondents were also asked about the incorporation of parts of the agricultural education model in the ARD course. Almost all of respondents agreed that classroom and laboratory incorporation was equal to, superior, or definitely superior to previous curriculums. Over half of the respondents agreed that FFA and leadership and SAE incorporation was equal to, superior or definitely superior to previous curriculums. 
Over three quarters of the respondents agreed the course incorporated all aspects of an agricultural education program.

Teachers were asked to evaluate their student's perceptions of the ARD course. Over three quarters of the respondents somewhat agreed to strongly agreed their students enjoyed the creativity and spontaneity of the ARD lessons. Over half the respondents agreed their students enjoyed the course overall. Respondents were also asked to evaluate their student's level of positive excitement over time on a scale from 1-100. The average mean was 64.81 with a standard deviation of 27.17 .

\section{Conclusions and Implications}

The evaluation of the CASE curriculum, through its active courses, proved to have some interesting conclusions. The majority of the people, who attended training for a course or several courses, are at least teaching one CASE curriculum course in a classroom. The respondents who were not using the curriculum had reasons for not using it. The majority of the reason was funding. The materials for the lessons and labs are necessary and without purchasing everything, the curriculum is ineffective. Most respondents were trained in the Introduction to Agriculture, Food and Natural Resources course. Principles of Agricultural Science- Animal and Principles of Agricultural Science-Plant were next with the most individuals trained. Over three quarters of respondents were not trained in an entire pathway.

1. To determine the perceptions of educators using the CASE curriculum related to the lesson plans, materials and courses in the curriculum.

The curriculum for the courses was well received. The majority agreed the lessons and PowerPoints included appropriate materials for lessons and units. Respondents 
agreed they were user friendly and contained an appropriate amount of information. Overall, the response to the courses and their contents were well received by the population.

2. To determine the perceptions of educators about the CASE curriculum training.

The training was very well received by respondents for every course. All respondents agreed it prepared them to use the course materials, they felt comfortable using it after the training and their knowledge improved. This all lead to an improvement in their teaching and students learning. Not many respondents required assistance once in the classroom, and those who did receive assistance when they needed it. The training overall was a high point for the curriculum according to respondents. The training is very well received, but the professional development aspect is not well utilized. The respondents who required assistance after the training, the majority of the time was a low number. Of those respondents, not all of them answered the questions about post training assistance. This makes it seem like the aspects of post training are not well advertised in the training. The National Association of Agricultural Educators Community of Practice Forum would be a good place for CASE educators to communicate ideas about using the curriculum or go to for assistance. Currently, it is not used by a majority of the CASE population. This could help solve problems in the classroom and be a platform for educators to go to talk about ideas, it may even lead to a solution to help improve the some of the excitement levels.

3. To determine the perceptions of educators on the CASE curriculum as it relates to the total agricultural education model. 
The incorporation of the parts of the agricultural education model had most agreement on classroom and laboratory incorporation compared to previous curriculums. FFA and leadership and SAEs were on the weaker side of incorporation. The majority of respondents for every course felt that FFA and leadership, SAE or both were lacking in the course. The majority of respondents rated overall that the courses did incorporate all parts of an agricultural education program. Respondents who had previously used the CASE curriculum and stopped were asked their main reasons for ceasing use. The majority of respondents quit using because of funding issues. There are lots of materials to purchase and many schools do not have the funding. Another large reason was the course content level. There was a discrepancy between the content being too complicated or complex for students, and the content level being too basic.

4. To determine the perceptions and attitudes of students' views of the CASE curriculum as perceived by their teachers.

Respondents were asked their perceptions of their student's views toward the courses. The majority of respondents agreed that the students enjoyed the creativity and spontaneity of the lessons in the course. Although they enjoyed it and their learning improved, the student's levels of positive excitement were around average, with a mean of 50 on a scale form 1-100, or slightly above.

\section{Recommendations}

\section{For CASE:}

1. Promote the online professional development aspect so teachers have a place to go to collaborate on ideas. 
2. Create an online professional development aspect that is just for CASE members to use to collaborate and share ideas.

3. Focus groups on what can get students more excited about the courses.

4. Workshops and focus groups for teachers to interact with one another. For teachers:

1. Focus group on ideas to help with the funding issue so more teachers can utilize the full curriculum.

2. A more in depth background of those teaching each course to clarify why they rated FFA and SAE higher than those in other areas.

3. Ideas with other teachers on how to get students more involved and excited about the lessons.

For future research:

1. A qualitative study of teachers who have used CASE and quit using it.

2. A study of lead teachers in CASE and how they address student motivation in the training.

3. A study to determine the learning style of students in the classes.

4. Further investigation on learning level of students in the classes. This would help figure out the discrepancy on too basic versus too complicated. 


\section{REFERENCES}

Asunda, P. (2011). Open courseware and STEM initiatives in career and technical education. Journal of STEM Teacher Education, 48(2), 6-37.

Ary, D., Jacobs, L. C., Sorenson, C., \& Walker, D. A. (2014). Introduction to research in education (9th ed.). Belmont CA: Wadsworth Cengage Learning.

Boone, H., Doerfert, D., \& Elliot, J., (1987) Supervise occupational experience programs: history, philosophy, current status and future implications. Journal of the American Association of Teacher Educators in Agriculture, 28(4). Retrieved from http://www.jae-

online.org/attachments/article/878/Boone,\%20H_et.al_Vol28_4_57-64.pdf.

Boone, H.N., Gartin, S.A., Boone, D.A., \& Hughes, J.E. (2006). Modernizing the agricultural education curriculum: An analysis of agricultural education teachers' attitudes, knowledge, and understanding of biotechnology. Journal of Agricultural Education, 47(1). Retrieved from:

http://pubs.aged.tamu.edu/jae/pdf/Vol47/47-01078.pdf?origiF=publication_detail.

Bouwma-Gearhart, J. (2012). Science faculty improving teaching practice: Identifying needs and finding meaningful professional development. International Journal of Teaching and Learning in Higher Education, 24(2), 180-188.

Cohen D., McLaughlin M., \& Talbert J., (eds). Teaching for understanding: Challenges for policy and practice (499-502). San Francisco: Jossey-Bass, 1993.

Common Core Standards Initiative. (2012). About the standards. Retrieved, from http://www.corestandards.org/about-the-standards/development-process/. 
Curriculum for Agricultural Science Education. (2012). CASE information. Retrieved from http://case4learning.org/.

Desimone, L. M. (2009). Improving impact studies of teachers' professional development: Toward better conceptualizations and measures. Educational Researcher, 38(3), 181-199. doi: 10.3102/0013189X0833114.

Desimone, L. M., Andrew, A. C., Garet, M., Yoon, K.S., and Birman, B. Does professional development change teachers' instruction? Results From a ThreeYear Study." Educational Evaluation and Policy Analysis, 24(2), 81-112.

Daniels, J. (2013). CASE: Worth the sacrifice. Agricultural Education Magazine, 85(2), $12-13$.

Dillman, D.A., Tortora, R.D., \& Bowker, D. (1999). Principles for construction web surveys. Retrieved from http://claudiaflowers.net/rsch8140/PrinciplesforConstructingWebSurveys.pdf.

Dyer, L. (2013). From good to great. Agricultural Education Magazine, 85(2), 10-11.

Filimore, J. (2013). CASE Makes Science Sense. Agriculture Education Magazine, 85(2), $8-9$.

Grier, A. (2005). Integrating needs assessment into career and technical curriculum development. Journal of Industrial Teacher Education, 42(1), 59-66.

Herschbach, D. (2011). The STEM initiative: Constraints and challenges. Journal of STEM Teacher Education, 48(1), 96-122.

Jansen, D. (2013). CASE: Positioning agricultural education as a solution for school-wide challenges. Agricultural Education Magazine, 85(2), 16- 17. 
Johnson, D. M., \& Newman, M. E. (1993). Perceptions of administrators, guidance counselors, and science teachers concerning pilot agriscience courses. Journal of Agricultural Education, 34(2), 46-54.

Lamb, J. (2013). CASE: An investment in time. Agricultural Education Magazine, 85(2), 14-15.

Lambert, M.D., \& Elliott, K. M. (2013). 9 tips from teachers who have implemented CASE. Agricultural Education Magazine, 85(2). 18-19.

Lawrenz, F., Huffman, D. \& Thomas, K. (2006). Synthesis of STEM education evaluation ideas. New directions for evaluation, 105-108. Doi: 10.1002/ev.181.

Lewy, A. (1977). Planning the school curriculum. Paris: Unesco, International Institute for Educational Planning.

Male, B. (2012). A $21^{\text {st }}$ Century Curriculum? In The primary curriculum design handbook: Preparing our children for the $21^{\text {st }}$ century. London: Continuum.

McNeil, J.D. (1990). Curriculum: A comprehensive introduction. Boston: Little, Brown and Co.

Mensch, M. (2013). Frequently asked CASE questions. Agricultural Education Magazine, 85(2). 20-22.

Meyers, B. (2016, January/February). History and philosophy of supervised agriculture experience programs. Lecture. Retrieved February 9, 2016, from http://lyra.ifas.ufl.edu/unzip/RLO_MODULE_AEC_3323_History_and_Philosophy_of_Supervised_Agricultural_Experience_Programsx29 06752y3/player.html. 
National Association of Agricultural Educators. (2015). What is agricultural education? Retrieved from http://www.naae.org/whatisaged/index.cfm.

National Education Association. (1918). Cardinal principles of secondary education: A report of the commission on the reorganization of secondary education. Washington, D.C.: United States Government Printing Office.

National FFA Organization. (2013). About us: who we are. Retrieved November 20, 2014, from: https://www.ffa.org/about/whoweare/Pages/AgriculturalEducation.aspx.

National FFA Organization. (2015). About: FFA history. Retrieved January 11, 2016, from https://www.ffa.org/about/what-is-ffa/ffa-history.

National FFA Organization. (2015). About: supervised agricultural experiences. Retrieved from https://www.ffa.org/about/supervised-agricultural-experiences. National Research Council. (1996). National science education standards. Washington, DC: National Academy Press. Retrieved from http://www.nap.edu/catalog/4962.html.

Noddings, N. (2007). Curriculum for the 21st century. Educational Studies in Japan: International Yearbook, (2), 75-81.

Retallick, M. S. (2013). Transformation learning in action. Agricultural Education Magazine, 85(2). 4-13.

Schloesser, B. (2013). Hey, what do you know about CASE? Agricultural Education Magazine, 85(2). 5-7.

Tyler, R. W. (1949). Basic principles of curriculum and instruction. Chicago: University of Chicago Press. 
Ulmer, J.D., Velez, J.J., Lambert. M.D., Thompson, G.W., Burris, S., \& Witt, P.A. (2013). Exploring Science Teaching Efficacy of CASE curriculum teachers: A post-then-pre assessment. Journal of Agricultural Education, 54(4). 121-133 DOI: 10.5032/jae.2013.04121.

Witt, P.A., Ulmer, J.D., Burris, S., Brashears, T., \& Burley, H. (2014). A comparison of student engaged time in agriculture instruction. Journal of Agricultural Education, 55(2). 16-32. DOI: 10.5032/jae.2014.02016. 
APPENDIX A

Cover Letter Email 
Dear CASE educators:

As completers of the CASE training and currently using the CASE curriculum, you are a vital part of this study. The CASE curriculum is becoming an important part of our education system as it is developing in states all across the United States. Understanding the curriculum is important, but there has been little done on understanding how individuals view the CASE curriculum.

I am Lauren Devine a graduate student at West Virginia University in Agricultural Education and Extension. Under my advisor, Dr. Stacy Gartin, the purpose of this study is to gain the understanding of the attitudes and views of educators who use the CASE curriculum. The study will be aimed toward the views of educators across the United States.

The results will provide a baseline for educators on the attitudes of the CASE curriculum. Research has only been done on the effectiveness of the curriculum, not on the attitudes of the educators using it. The results can serve to help CASE identify positive areas of the curriculum and areas that are still weaker within the curriculum.

Participation in this survey is voluntary and all the information given will be kept confidential. The survey will take you about five to ten minutes to complete. Your responses to this survey are crucial to the development of the study. You may skip any question you do not want to answer or are not comfortable with. You can stop answering at any time. The survey is available online at the link listed below. Survey results will be statically analyzed.

Follow this link to the Survey:

$\$\{1: / /$ SurveyLink?d=Take the Survey $\}$

Or copy and paste the URL below into your internet browser:

$\$\{1: / /$ SurveyURL $\}$

The Institutional Review Board (IRB) at West Virginia University has approved this study. If you have any questions or comments about this study or completing the survey, please email ldaub@mix.wvu.edu.

Please complete the survey by $02 / 12 / 16$. Thank you in advance for your completion of the survey and help in obtaining information on this important study. We appreciate your help in completing this survey.

Sincerely,

Lauren Devine

Master Student
Stacy Gartin

Professor: Agricultural Education 
APPENDIX B

Instrument 


\section{Perceptions of the Curriculum of Agricultural Science Education (CASE) as perceived by Agriculture Educators}

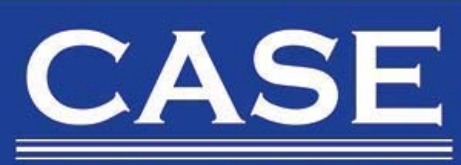

Curriculum for Agricultural Science Education

EMPOWERING TEACHERS FOR STUDENT SUCCESS IN STEM

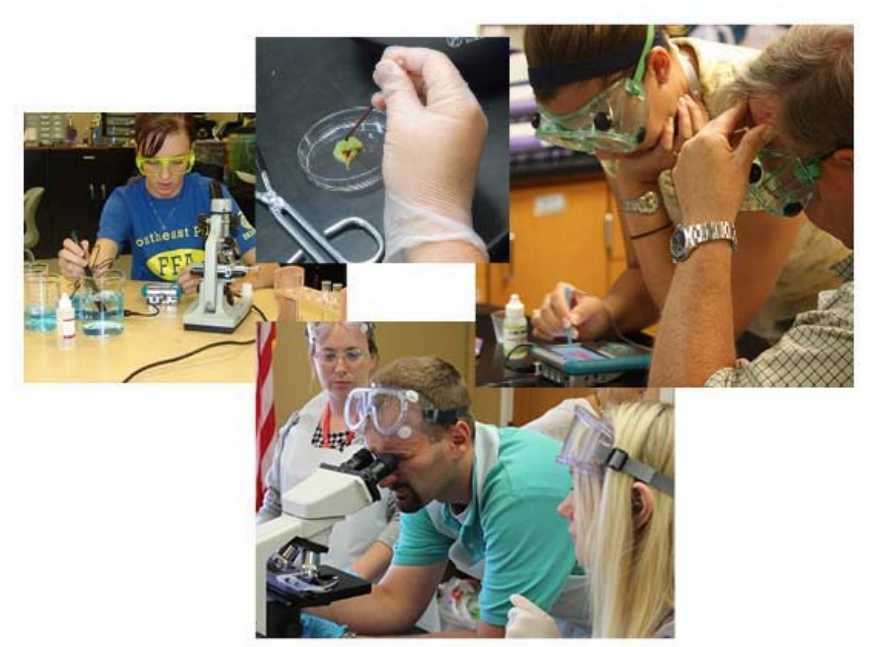

Lauren Irene Devine

Graduate Student

Agricultural and Extension Education

Davis College of Agriculture, Natural Resource, and Design

West Virginia University

Morgantown, WV 26506 


\section{CASE Courses Survey}

Q1 Directions: Please select the CASE curriculum courses in which you have been trained. If you have been trained in multiple courses, please select all that apply. In which CASE Pathways have you been trained?

Introduction to Agriculture, Food and Natural Resources

a Agricultural Science-Animal

- Agricultural Science- Plant

agricultural Power and Technology

- Natural Resources and Ecology

- Animal and Plant Biotechnology

Food Science and Safety

$\square$ Agricultural Research and Development

Answer If-- Directions: Please select the CASE curriculum courses in which you have been trained. If you have been trained in multiple courses, please select all that apply....Introduction to Agriculture, Food and Natural Resources Is Selected Q2 Did you teach the Introduction to Agriculture, Food and Natural Resources (AFNR) course curriculum in a classroom?

$\mathrm{O}$ Yes

O No

If Yes Is Selected, Then Skip To: Course: Introduction to Agriculture, Food and Natural Resources, Directions: Using the scale below, please indicate the degree to which you agree or disagree with the following statements about the 10 day CASE training on the Introduction to Agriculture, Food and Natural Resources (AFNR) course...If No Is Selected, Then Skip To End of Block (Demographics)

Answer If-- Directions: Please select the CASE curriculum courses in which you have been trained. If you have been trained in multiple courses, please select all that apply....Introduction to Agriculture, Food and Natural Resources Is Selected Course: Introduction to Agriculture, Food and Natural Resources (AFNR)

Q3 Directions: Using the scale below, please indicate the degree to which you agree or disagree with the following statements about the 10 day CASE training on the Introduction to Agriculture, Food and Natural Resources (AFNR) course.

Strongly Disagree
Disagree
Somewhat Somewhat Disagree
Agree

Strongly

Agree 


\begin{tabular}{|c|c|c|c|c|c|c|}
\hline $\begin{array}{l}\text { The CASE } \\
\text { training } \\
\text { prepared } \\
\text { individuals } \\
\text { to } \\
\text { implement } \\
\text { the AFNR } \\
\text { CASE } \\
\text { course. }\end{array}$ & 0 & 0 & 0 & 0 & 0 & 0 \\
\hline $\begin{array}{l}\text { The CASE } \\
\text { training } \\
\text { prepared } \\
\text { individuals } \\
\text { to use the } \\
\text { CASE } \\
\text { curriculum } \\
\text { AFNR } \\
\text { course } \\
\text { lesson } \\
\text { plans. }\end{array}$ & 0 & 0 & 0 & 0 & 0 & 0 \\
\hline $\begin{array}{l}\text { The CASE } \\
\text { training } \\
\text { adequately } \\
\text { prepared } \\
\text { individuals } \\
\text { to use the } \\
\text { AFNR } \\
\text { course } \\
\text { CASE } \\
\text { Power } \\
\text { Points } \\
\text { included in } \\
\text { the } \\
\text { curriculum. }\end{array}$ & 0 & 0 & 0 & 0 & 0 & 0 \\
\hline
\end{tabular}

Answer If-- Directions: Please select the CASE curriculum courses in which you have been trained. If you have been trained in multiple courses, please select all that apply....Introduction to Agriculture, Food and Natural Resources Is Selected

Q4 Did you require assistance after the training at the CASE institute when implementing the curriculum in the classroom?

$\mathrm{O}$ Yes

O No

If Yes Is Selected, Then Skip To :Course: Introduction to Agriculture, Food and Natural Resources, Directions: Using the scale below, please indicate the degree to which 
you agree or disagree with the following statements about professional development with CASE staff and lead teachers that followed the Introduction to Agriculture, Food and Natural Resources (AFNR) course CASE training...If No Is Selected, Then Skip To Course: Introduction to Agriculture, Food and Natural Resources, Directions: Using the scale below, please indicate the degree to which you agree or disagree with the following statements about the use of the CASE curriculum following the training for the Introduction to Agriculture, Food and Natural Resources (AFNR) course. These statements are based on the use of the Introduction to Agriculture, Food and Natural Resources (AFNR) course in the classroom following the training.

Answer If-- Directions: Please select the CASE curriculum courses in which you have been trained. If you have been trained in multiple courses, please select all that apply....Introduction to Agriculture, Food and Natural Resources Is Selected Course: Introduction to Agriculture, Food and Natural Resources (AFNR)

Q5 Directions: Using the scale below, please indicate the degree to which you agree or disagree with the following statements about professional development with CASE staff and lead teachers that followed the Introduction to Agriculture, Food and Natural Resources (AFNR) course CASE training.

\begin{tabular}{|c|c|c|c|c|c|c|}
\hline & $\begin{array}{l}\text { Strongly } \\
\text { Disagree }\end{array}$ & Disagree & $\begin{array}{c}\text { Somewhat } \\
\text { Disagree }\end{array}$ & $\begin{array}{l}\text { Somewhat } \\
\text { Agree }\end{array}$ & Agree & $\begin{array}{l}\text { Strongly } \\
\text { Agree }\end{array}$ \\
\hline $\begin{array}{l}\text { I received } \\
\text { assistance } \\
\text { from a CASE } \\
\text { staff member } \\
\text { or lead teacher } \\
\text { when } \\
\text { implementing } \\
\text { the CASE } \\
\text { curriculum. }\end{array}$ & 0 & 0 & 0 & 0 & 0 & 0 \\
\hline $\begin{array}{l}\text { The } \\
\text { professional } \\
\text { development } \\
\text { was helpful for } \\
\text { problems that } \\
\text { arose over } \\
\text { time using } \\
\text { the curriculum. }\end{array}$ & 0 & 0 & O & O & 0 & 0 \\
\hline $\begin{array}{l}\text { The } \\
\text { professional }\end{array}$ & O & 0 & 0 & 0 & 0 & 0 \\
\hline
\end{tabular}




\begin{tabular}{|l|l|l|l|l|}
\hline development & & & & \\
aspect & & & & \\
involved & & & & \\
interactions & & & & \\
through the & National & & & \\
Association of & & & \\
Agricultural & Educators & & & \\
Community of & & & & \\
Practice & & & & \\
Forum. & & & & \\
\hline
\end{tabular}


Answer If-- Directions: Please select the CASE curriculum courses in which you have been trained. If you have been trained in multiple courses, please select all that apply....Introduction to Agriculture, Food and Natural Resources Is Selected

Course: Introduction to Agriculture, Food and Natural Resources (AFNR)

Q6 Directions: Using the scale below, please indicate the degree to which you agree or disagree with the following statements about the use of the CASE curriculum following the training for the Introduction to Agriculture, Food and Natural Resources

\begin{tabular}{|c|c|c|c|c|c|c|}
\hline & $\begin{array}{l}\text { Strongly } \\
\text { Disagree }\end{array}$ & Disagree & $\begin{array}{l}\text { Somewhat } \\
\text { Disagree }\end{array}$ & $\begin{array}{c}\text { Somewhat } \\
\text { Agree }\end{array}$ & Agree & $\begin{array}{c}\text { Strongly } \\
\text { Agree }\end{array}$ \\
\hline $\begin{array}{l}\text { I was } \\
\text { comfortable } \\
\text { using the } \\
\text { curriculum } \\
\text { in the } \\
\text { classroom. }\end{array}$ & 0 & 0 & 0 & 0 & 0 & 0 \\
\hline $\begin{array}{l}\text { My } \\
\text { knowledge } \\
\text { and skills } \\
\text { of the } \\
\text { material } \\
\text { increased } \\
\text { from the } \\
\text { training. }\end{array}$ & 0 & $\bigcirc$ & 0 & $\bigcirc$ & 0 & 0 \\
\hline $\begin{array}{l}\text { The } \\
\text { training led } \\
\text { to a } \\
\text { positive } \\
\text { change in } \\
\text { my } \\
\text { instruction. }\end{array}$ & 0 & 0 & 0 & 0 & 0 & 0 \\
\hline $\begin{array}{l}\text { My } \\
\text { students } \\
\text { learning } \\
\text { improved. }\end{array}$ & 0 & 0 & 0 & 0 & 0 & 0 \\
\hline
\end{tabular}


Answer If-- Directions: Please select the CASE curriculum courses in which you have been trained. If you have been trained in multiple courses, please select all that apply....Introduction to Agriculture, Food and Natural Resources Is Selected

Course: Introduction to Agriculture, Food and Natural Resources (AFNR)

Q7 Directions: Using the scale below, please indicate the degree to which you agree or disagree with the following statements about the Introduction to Agriculture, Food and Natural Resources (AFNR) course lesson plans and supporting materials.

\begin{tabular}{|c|c|c|c|c|c|c|}
\hline & $\begin{array}{l}\text { Strongly } \\
\text { Disagree }\end{array}$ & Disagree & $\begin{array}{l}\text { Somewhat } \\
\text { Disagree }\end{array}$ & $\begin{array}{l}\text { Somewhat } \\
\text { Agree }\end{array}$ & Agree & $\begin{array}{c}\text { Strongly } \\
\text { Agree }\end{array}$ \\
\hline $\begin{array}{l}\text { The AFNR } \\
\text { course } \\
\text { CASE lesson } \\
\text { plans are } \\
\text { user friendly } \\
\text { to anyone } \\
\text { who tries to } \\
\text { use them. }\end{array}$ & 0 & 0 & 0 & 0 & 0 & O \\
\hline $\begin{array}{l}\text { The AFNR } \\
\text { course } \\
\text { CASE lesson } \\
\text { plans contain } \\
\text { the material } \\
\text { to be taught } \\
\text { in each } \\
\text { lesson. }\end{array}$ & O & 0 & $\mathrm{O}$ & O & 0 & O \\
\hline $\begin{array}{l}\text { The AFNR } \\
\text { course } \\
\text { CASE lesson } \\
\text { plans contain } \\
\text { the material } \\
\text { to be taught } \\
\text { in each unit. }\end{array}$ & O & $\mathrm{O}$ & 0 & $\mathrm{O}$ & $\mathrm{O}$ & O \\
\hline $\begin{array}{l}\text { The AFNR } \\
\text { course } \\
\text { CASE lesson } \\
\text { plans overall } \\
\text { contain the } \\
\text { needed } \\
\text { amount of } \\
\text { material. }\end{array}$ & O & O & 0 & O & 0 & O \\
\hline
\end{tabular}


Answer If-- Directions: Please select the CASE curriculum courses in which you have been trained. If you have been trained in multiple courses, please select all that apply....Introduction to Agriculture, Food and Natural Resources Is Selected Course: Introduction to Agriculture, Food and Natural Resources (AFNR)

Q8 Directions: Using the scale below, please compare the Introduction to Agriculture, Food and Natural Resources (AFNR) course CASE curriculum to the curriculum used prior to the CASE curriculum on the following areas. For each of the following areas, the CASE Introduction to Agriculture, Food and Natural Resources (AFNR) is when compared to previous curriculum.

\begin{tabular}{|l|c|c|c|c|c|}
\hline $\begin{array}{l}\text { Definitely } \\
\text { Inferior }\end{array}$ & Inferior & Equal To & Superior & $\begin{array}{c}\text { Definitely } \\
\text { Superior }\end{array}$ \\
\hline $\begin{array}{l}\text { and } \\
\text { laboratory }\end{array}$ & 0 & 0 & 0 & 0 & 0 \\
$\begin{array}{l}\text { FFA and } \\
\text { leadership } \\
\begin{array}{l}\text { Supervised } \\
\text { Agriculture }\end{array}\end{array}$ & 0 & 0 & 0 & 0 & 0 \\
$\begin{array}{l}\text { Experiences } \\
\text { (SAE) }\end{array}$ & 0 & 0 & 0 & 0 & 0 \\
$\begin{array}{l}\text { All aspects } \\
\text { of an } \\
\text { Agricultural } \\
\text { education }\end{array}$ & 0 & 0 & 0 & 0 & 0 \\
\hline \begin{tabular}{l} 
Program \\
\hline
\end{tabular} & & & & & \\
\hline
\end{tabular}


Answer If-- Directions: Please select the CASE curriculum courses in which you have been trained. If you have been trained in multiple courses, please select all that apply....Introduction to Agriculture, Food and Natural Resources Is Selected

Course: Introduction to Agriculture, Food and Natural Resources (AFNR)

Q9 Directions: Using the scale below, please indicate the degree to which you agree or disagree with the following statements about the students' views of the CASE curriculum Introduction to Agriculture, Food and Natural Resources (AFNR) course.

\begin{tabular}{|c|c|c|c|c|c|c|}
\hline & $\begin{array}{l}\text { Strongly } \\
\text { Disagree }\end{array}$ & Disagree & $\begin{array}{l}\text { Somewhat } \\
\text { Disagree }\end{array}$ & $\begin{array}{c}\text { Somewhat } \\
\text { Agree }\end{array}$ & Agree & $\begin{array}{c}\text { Strongly } \\
\text { Agree }\end{array}$ \\
\hline $\begin{array}{l}\text { Students } \\
\text { enjoyed the } \\
\text { creativity } \\
\text { of the } \\
\text { AFNR } \\
\text { course } \\
\text { lessons. }\end{array}$ & 0 & 0 & 0 & 0 & 0 & 0 \\
\hline $\begin{array}{l}\text { Students } \\
\text { enjoyed the } \\
\text { spontaneity } \\
\text { of the } \\
\text { AFNR } \\
\text { course } \\
\text { lessons. }\end{array}$ & 0 & 0 & 0 & $\bigcirc$ & 0 & 0 \\
\hline $\begin{array}{l}\text { Students } \\
\text { enjoyed the } \\
\text { AFNR } \\
\text { course. }\end{array}$ & 0 & 0 & 0 & 0 & 0 & 0 \\
\hline
\end{tabular}

Answer If-- Directions: Please select the CASE curriculum courses in which you have been trained. If you have been trained in multiple courses, please select all that apply....Introduction to Agriculture, Food and Natural Resources Is Selected

Q10 Please slide the bar to indicate the level of positive excitement of your students as you implemented the AFNR course CASE Curriculum. 0 represents the lowest level of excitement and 100 represents the highest level of excitement.

Students positive excitement at the beginning of the course.

Students positive excitement in the middle of course.

Students positive excitement at the end of the course. 
Answer If--Directions: Please select the CASE curriculum courses in which you have been trained. If you have been trained in multiple courses, please select all that apply... Agricultural Science-Animal Is Selected

Q11 Did you teach the Principles of Agricultural Science- Animal (ASA) CASE curriculum course in a classroom?

O Yes

O No

If Yes Is Selected, Then Skip To Course: Principles of Agricultural Science-Animal, Directions: Using the scale below, please indicate the degree to which you agree or disagree with the following statements about the 10 day CASE training on the Principles of Agricultural Science- Animal (ASA) course....If No Is Selected, Then Skip To End of Block (Demographics)

Answer If--Directions: Please select the CASE curriculum courses in which you have been trained. If you have been trained in multiple courses, please select all that apply... Agricultural Science-Animal Is Selected Course: Principles of Agricultural Science- Animal (ASA)

Q12 Directions: Using the scale below, please indicate the degree to which you agree or disagree with the following statements about the 10 day CASE training on the Principles of Agricultural Science- Animal (ASA) course. 


\begin{tabular}{|c|c|c|c|c|c|c|}
\hline & $\begin{array}{l}\text { Strongly } \\
\text { Disagree }\end{array}$ & Disagree & $\begin{array}{l}\text { Somewhat } \\
\text { Disagree }\end{array}$ & $\begin{array}{c}\text { Somewhat } \\
\text { Agree }\end{array}$ & Agree & $\begin{array}{c}\text { Strongly } \\
\text { Agree }\end{array}$ \\
\hline $\begin{array}{l}\text { The CASE } \\
\text { training } \\
\text { prepared } \\
\text { individuals } \\
\text { to } \\
\text { implement } \\
\text { the ASA } \\
\text { CASE } \\
\text { course. }\end{array}$ & O & 0 & O & 0 & 0 & 0 \\
\hline $\begin{array}{l}\text { The CASE } \\
\text { training } \\
\text { prepared } \\
\text { individuals } \\
\text { to use the } \\
\text { CASE } \\
\text { curriculum } \\
\text { ASA } \\
\text { course } \\
\text { lesson } \\
\text { plans. }\end{array}$ & 0 & O & 0 & 0 & 0 & . \\
\hline $\begin{array}{l}\text { The CASE } \\
\text { training } \\
\text { adequately } \\
\text { prepared } \\
\text { individuals } \\
\text { to use the } \\
\text { ASA } \\
\text { course } \\
\text { CASE } \\
\text { Power } \\
\text { Points } \\
\text { included in } \\
\text { the } \\
\text { curriculum. }\end{array}$ & 0 & 0 & 0 & 0 & 0 & 0 \\
\hline
\end{tabular}


Answer If--Directions: Please select the CASE curriculum courses in which you have been trained. If you have been trained in multiple courses, please select all that apply... Agricultural Science-Animal Is Selected

Q13 Did you require assistance after the training at the CASE institute when implementing the curriculum in the classroom?

$\mathrm{O}$ Yes

O No

If Yes Is Selected, Then Skip To Y Course: Principles of Agricultural- Animal,

Directions: Using the scale below, please indicate the degree to which you agree or disagree with the following statements about professional development with CASE staff and lead teachers that followed the Principles of Agricultural ScienceAnimal (ASA) course CASE training. ...If No Is Selected, Then Skip To Course: Principles of Agricultural Science- Animal, Directions: Using the scale below, please indicate the degree to which you agree or disagree with the following statements about the use of the CASE curriculum following the training for the Principles of Agricultural Science- Animal (ASA) course. These statements are based on the use of the Principles of Agricultural Science-Animal (ASA) course in the classroom following the training.... Answer If--Directions: Please select the CASE curriculum courses in which you have been trained. If you have been trained in multiple courses, please select all that apply... Agricultural Science-Animal Is Selected

Course: Principles of Agricultural Science- Animal (ASA)

Q14 Directions: Using the scale below, please indicate the degree to which you agree or disagree with the following statements about professional development with CASE staff and lead teachers that followed the Principles of Agricultural Science- Animal (ASA) course CASE training. 


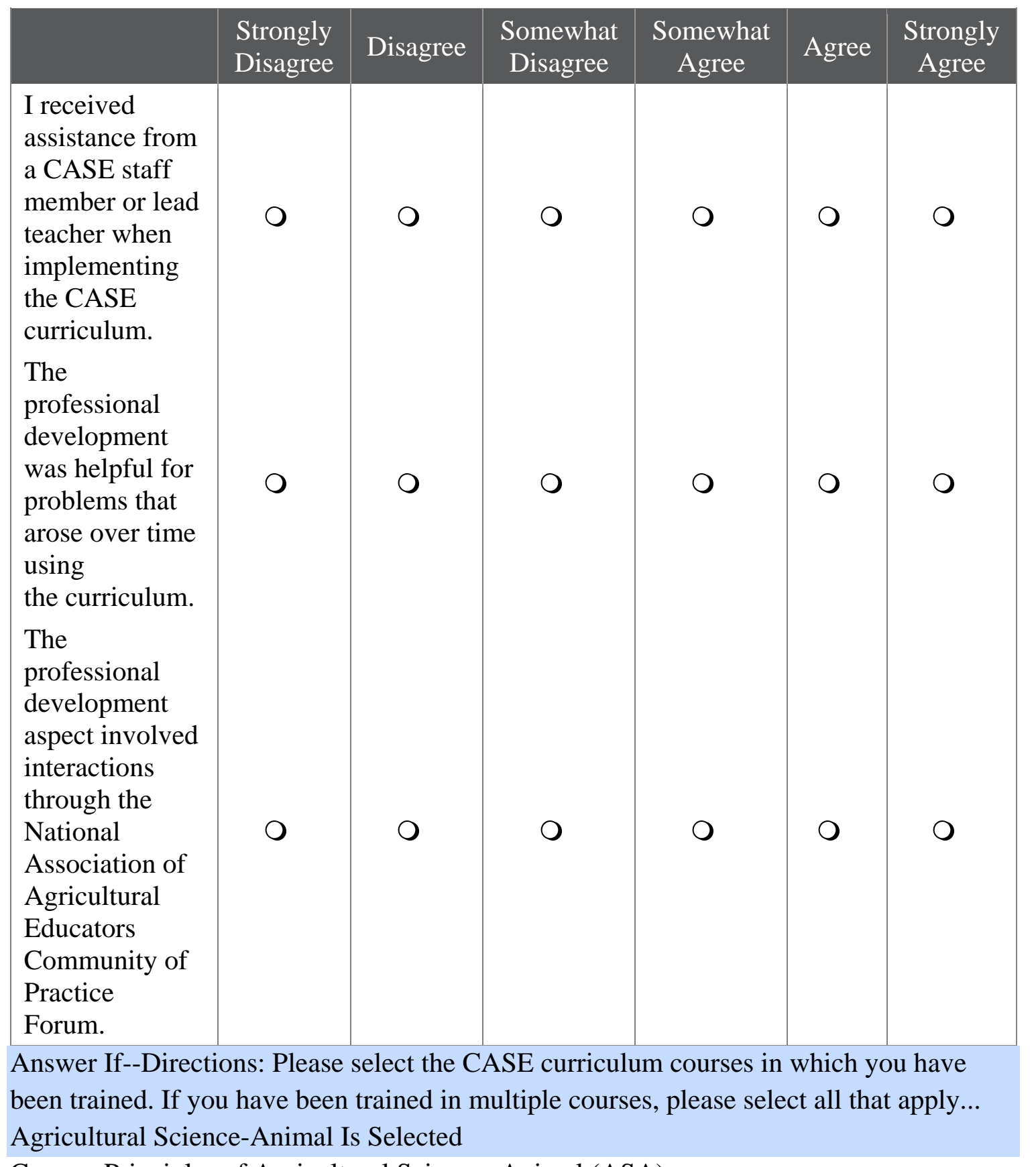

Course: Principles of Agricultural Science- Animal (ASA)

Q15 Directions: Using the scale below, please indicate the degree to which you agree or disagree with the following statements about the use of the CASE curriculum following the training for the Principles of Agricultural Science- Animal (ASA) course. These 
statements are based on the use of the Principles of Agricultural Science-Animal (ASA) course in the classroom following the training.

\begin{tabular}{|c|c|c|c|c|c|c|}
\hline & $\begin{array}{l}\text { Strongly } \\
\text { Disagree }\end{array}$ & Disagree & $\begin{array}{l}\text { Somewhat } \\
\text { Disagree }\end{array}$ & $\begin{array}{c}\text { Somewhat } \\
\text { Agree }\end{array}$ & Agree & $\begin{array}{c}\text { Strongly } \\
\text { Agree }\end{array}$ \\
\hline $\begin{array}{l}\text { I was } \\
\text { comfortable } \\
\text { using the } \\
\text { curriculum } \\
\text { in the } \\
\text { classroom. }\end{array}$ & 0 & 0 & 0 & O & 0 & 0 \\
\hline $\begin{array}{l}\text { My } \\
\text { knowledge } \\
\text { and skills } \\
\text { of the } \\
\text { material } \\
\text { increased } \\
\text { from the } \\
\text { training. }\end{array}$ & 0 & 0 & 0 & 0 & 0 & 0 \\
\hline $\begin{array}{l}\text { The } \\
\text { training led } \\
\text { to a } \\
\text { positive } \\
\text { change in } \\
\text { my } \\
\text { instruction. }\end{array}$ & 0 & 0 & 0 & 0 & 0 & 0 \\
\hline $\begin{array}{l}\text { My } \\
\text { students } \\
\text { learning } \\
\text { improved. }\end{array}$ & 0 & 0 & 0 & 0 & 0 & 0 \\
\hline
\end{tabular}

Answer If--Directions: Please select the CASE curriculum courses in which you have been trained. If you have been trained in multiple courses, please select all that apply... Agricultural Science-Animal Is Selected

Course: Principles of Agricultural Science-Animal (ASA)

Q16 Directions: Using the scale below, please indicate the degree to which you agree or disagree with the following statements about the Principles of Agricultural ScienceAnimal (ASA) course lesson plans and supporting materials. 


\begin{tabular}{|c|c|c|c|c|c|c|}
\hline & $\begin{array}{l}\text { Strongly } \\
\text { Disagree }\end{array}$ & Disagree & $\begin{array}{l}\text { Somewhat } \\
\text { Disagree }\end{array}$ & $\begin{array}{l}\text { Somewhat } \\
\text { Agree }\end{array}$ & Agree & $\begin{array}{c}\text { Strongly } \\
\text { Agree }\end{array}$ \\
\hline $\begin{array}{l}\text { The ASA } \\
\text { course } \\
\text { CASE lesson } \\
\text { plans are } \\
\text { user friendly } \\
\text { to anyone } \\
\text { who tries to } \\
\text { use them. }\end{array}$ & O & O & 0 & O & 0 & O \\
\hline $\begin{array}{l}\text { The ASA } \\
\text { course } \\
\text { CASE lesson } \\
\text { plans contain } \\
\text { the material } \\
\text { to be taught } \\
\text { in each } \\
\text { lesson. }\end{array}$ & O & 0 & 0 & O & 0 & 0 \\
\hline $\begin{array}{l}\text { The ASA } \\
\text { course } \\
\text { CASE lesson } \\
\text { plans contain } \\
\text { the material } \\
\text { to be taught } \\
\text { in each unit. }\end{array}$ & O & 0 & 0 & O & 0 & $\mathrm{O}$ \\
\hline $\begin{array}{l}\text { The ASA } \\
\text { course } \\
\text { CASE lesson } \\
\text { plans overall } \\
\text { contain the } \\
\text { needed } \\
\text { amount of } \\
\text { material. }\end{array}$ & 0 & 0 & 0 & 0 & 0 & 0 \\
\hline
\end{tabular}

Answer If--Directions: Please select the CASE curriculum courses in which you have been trained. If you have been trained in multiple courses, please select all that apply... Agricultural Science-Animal Is Selected Course: Principles of Agricultural Science- Animal (ASA)

Q17 Directions: Using the scale below, please compare the Principles of Agricultural Science- Animal (ASA) course CASE curriculum to curriculum used prior to the CASE 
curriculum on the following areas. For each of the following areas, the CASE Introduction to Principles of Agricultural Science- Animal (ASA) is when compared to previous curriculum.

\begin{tabular}{|l|c|c|c|c|c|}
\hline $\begin{array}{l}\text { Definitely } \\
\text { Inferior }\end{array}$ & Inferior & Equal To & Superior & $\begin{array}{c}\text { Definitely } \\
\text { Superior }\end{array}$ \\
\hline $\begin{array}{l}\text { Classroom } \\
\text { and } \\
\text { laboratory }\end{array}$ & 0 & 0 & 0 & 0 & 0 \\
$\begin{array}{l}\text { FFA and } \\
\text { leadership } \\
\begin{array}{l}\text { Supervised } \\
\text { Agriculture }\end{array}\end{array}$ & 0 & 0 & 0 & 0 & 0 \\
$\begin{array}{l}\text { Experiences } \\
\text { (SAE) }\end{array}$ & 0 & 0 & 0 & 0 & 0 \\
$\begin{array}{l}\text { All aspects } \\
\text { of an } \\
\text { Agricultural } \\
\text { education }\end{array}$ & 0 & 0 & 0 & 0 & 0 \\
\hline Program & & & & & \\
\hline Anwif-Dim & & 0 & & \\
\hline
\end{tabular}

Answer If--Directions: Please select the CASE curriculum courses in which you have been trained. If you have been trained in multiple courses, please select all that apply... Agricultural Science-Animal Is Selected

Course: Principles of Agricultural Science- Animal (ASA)

Q18 Directions: Using the scale below, please indicate the degree to which you agree or disagree with the following statements about the students' views of the CASE curriculum Principles of Agricultural Science- Animal (ASA) course. 


\begin{tabular}{|l|c|c|c|c|c|c|}
\hline & $\begin{array}{l}\text { Strongly } \\
\text { Disagree }\end{array}$ & Disagree & $\begin{array}{c}\text { Somewhat } \\
\text { Disagree }\end{array}$ & $\begin{array}{c}\text { Somewhat } \\
\text { Agree }\end{array}$ & Agree & $\begin{array}{c}\text { Strongly } \\
\text { Agree }\end{array}$ \\
\hline $\begin{array}{l}\text { Students } \\
\text { enjoyed the } \\
\text { creativity } \\
\text { of the ASA } \\
\text { course }\end{array}$ & 0 & 0 & 0 & 0 & 0 & 0 \\
lessons. \\
$\begin{array}{l}\text { Students } \\
\text { enjoyed the } \\
\text { spontaneity } \\
\text { of the ASA } \\
\text { course }\end{array}$ & 0 & 0 & 0 & 0 & 0 & 0 \\
lessons. \\
$\begin{array}{l}\text { Students } \\
\text { enjoyed the } \\
\text { ASA } \\
\text { course. }\end{array}$
\end{tabular}

Answer If--Directions: Please select the CASE curriculum courses in which you have been trained. If you have been trained in multiple courses, please select all that apply... Agricultural Science-Animal Is Selected

Q19 Please slide the bar to indicate the level of positive excitement of your students as you implemented the ASA course CASE Curriculum. 0 represents the lowest level of excitement and 100 represents the highest level of excitement.

Students positive excitement at the beginning of the course.

Students positive excitement in the middle of the course.

Students positive excitement at the end of the course.

Answer If--Directions: Please select the CASE curriculum courses in which you have been trained. If you have been trained in multiple courses, please select all that apply... Agricultural Science-Animal Is Selected

Q20 Did you teach the Principle of Agriculture Science- Plant (ASP) course in a classroom?
$\mathrm{O}$ Yes
O No

If No Is Selected, Then Skip To End of Block (Demographics) If Yes Is Selected, Then Skip To Course: Principles of Agricultural Science- Plant, Directions: Using the scale below, please indicate the degree to which you agree or disagree with the following 
statements about the 10 day CASE training on the Principles of Agricultural Science-

Plant (ASP) course.

Answer If --Directions: Please select the CASE curriculum courses in which you have been trained. If you have been trained in multiple courses, please select all that apply...

Agricultural Science- Plant Is Selected

Course: Principles of Agricultural Science- Plant (ASP)

Q21 Directions: Using the scale below, please indicate the degree to which you agree or disagree with the following statements about the 10 day CASE training on the Principles of Agricultural Science- Plant (ASP) course. 


\begin{tabular}{|c|c|c|c|c|c|c|}
\hline & $\begin{array}{l}\text { Strongly } \\
\text { Disagree }\end{array}$ & Disagree & $\begin{array}{l}\text { Somewhat } \\
\text { Disagree }\end{array}$ & $\begin{array}{c}\text { Somewhat } \\
\text { Agree }\end{array}$ & Agree & $\begin{array}{c}\text { Strongly } \\
\text { Agree }\end{array}$ \\
\hline $\begin{array}{l}\text { The CASE } \\
\text { training } \\
\text { prepared } \\
\text { individuals } \\
\text { to } \\
\text { implement } \\
\text { the ASP } \\
\text { CASE } \\
\text { course. }\end{array}$ & O & 0 & O & 0 & 0 & 0 \\
\hline $\begin{array}{l}\text { The CASE } \\
\text { training } \\
\text { prepared } \\
\text { individuals } \\
\text { to use the } \\
\text { CASE } \\
\text { curriculum } \\
\text { ASP } \\
\text { course } \\
\text { lesson } \\
\text { plans. }\end{array}$ & 0 & 0 & 0 & 0 & 0 & . \\
\hline $\begin{array}{l}\text { The CASE } \\
\text { training } \\
\text { adequately } \\
\text { prepared } \\
\text { individuals } \\
\text { to use the } \\
\text { ASP } \\
\text { course } \\
\text { CASE } \\
\text { Power } \\
\text { Points } \\
\text { included in } \\
\text { the } \\
\text { curriculum. }\end{array}$ & 0 & 0 & 0 & 0 & 0 & 0 \\
\hline
\end{tabular}


Answer If --Directions: Please select the CASE curriculum courses in which you have been trained. If you have been trained in multiple courses, please select all that apply... Agricultural Science- Plant Is Selected

Q22 Did you require assistance after the training at the CASE institute when implementing the curriculum in the classroom?

$\mathrm{O}$ Yes

O No

If Yes Is Selected, Then Skip To Course: Principles of Agricultural Science- Plant, Directions: Using the scale below, please indicate the degree to which you agree or disagree with the following statements about professional development with CASE staff and lead teachers that followed the Principles of Agricultural Science- Plant (ASP) course CASE training. ...If No Is Selected, Then Skip To Course: Principles of Agricultural Science- Plant, Directions: Using the scale below, please indicate the degree to which you agree or disagree with the following statements about the use of the CASE curriculum following the training for the Principles of Agricultural Science- Plant (ASP) course. These statements are based on the use of the Principles of Agricultural Science- Plant (ASP) course in the classroom following the training...

Answer --If Directions: Please select the CASE curriculum courses in which you have been trained. If you have been trained in multiple courses, please select all that apply... Agricultural Science- Plant Is Selected

Course: Principles of Agricultural Science- Plant (ASP)

Q23 Directions: Using the scale below, please indicate the degree to which you agree or disagree with the following statements about professional development with CASE staff and lead teachers that followed the Principles of Agricultural Science- Plant (ASP) course CASE training. 


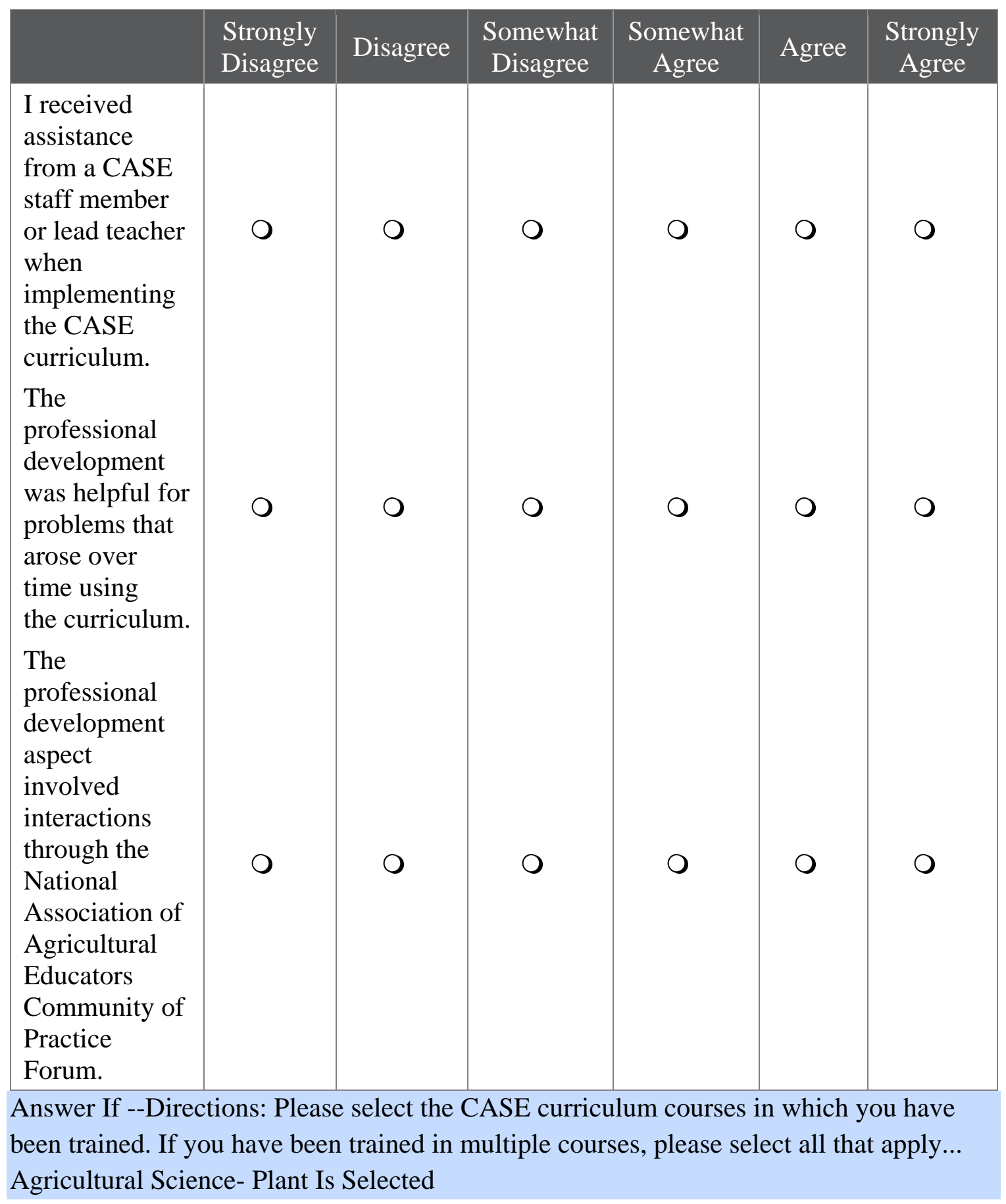

Course: Principles of Agricultural Science- Plant (ASP)

Q24 Directions: Using the scale below, please indicate the degree to which you agree or disagree with the following statements about the use of the CASE curriculum following the training for the Principles of Agricultural Science- Plant (ASP) course. These 
statements are based on the use of the Principles of Agricultural Science- Plant (ASP) course in the classroom following the training.

\begin{tabular}{|c|c|c|c|c|c|c|}
\hline & $\begin{array}{l}\text { Strongly } \\
\text { Disagree }\end{array}$ & Disagree & $\begin{array}{c}\text { Somewhat } \\
\text { Disagree }\end{array}$ & $\begin{array}{c}\text { Somewhat } \\
\text { Agree }\end{array}$ & Agree & $\begin{array}{c}\text { Strongly } \\
\text { Agree }\end{array}$ \\
\hline $\begin{array}{l}\text { I was } \\
\text { comfortable } \\
\text { using the } \\
\text { curriculum } \\
\text { in the } \\
\text { classroom. }\end{array}$ & 0 & 0 & 0 & O & $\mathrm{O}$ & $\mathrm{O}$ \\
\hline $\begin{array}{l}\text { My } \\
\text { knowledge } \\
\text { and skills } \\
\text { of the } \\
\text { material } \\
\text { increased } \\
\text { from the } \\
\text { training. }\end{array}$ & 0 & 0 & 0 & 0 & 0 & 0 \\
\hline $\begin{array}{l}\text { The } \\
\text { training led } \\
\text { to a } \\
\text { positive } \\
\text { change in } \\
\text { my } \\
\text { instruction. }\end{array}$ & 0 & 0 & 0 & 0 & 0 & 0 \\
\hline $\begin{array}{l}\text { My } \\
\text { students } \\
\text { learning } \\
\text { improved. }\end{array}$ & 0 & 0 & 0 & 0 & 0 & 0 \\
\hline
\end{tabular}


Answer If --Directions: Please select the CASE curriculum courses in which you have been trained. If you have been trained in multiple courses, please select all that apply...

\section{Agricultural Science- Plant Is Selected}

Course: Principles of Agricultural Science-Plant (ASP)

Q25 Directions: Using the scale below, please indicate the degree to which you agree or disagree with the following statements about the Principles of Agricultural Science- Plant (ASP) course lesson plans and supporting materials.

\begin{tabular}{|c|c|c|c|c|c|c|}
\hline & $\begin{array}{l}\text { Strongly } \\
\text { Disagree }\end{array}$ & Disagree & $\begin{array}{l}\text { Somewhat } \\
\text { Disagree }\end{array}$ & $\begin{array}{c}\text { Somewhat } \\
\text { Agree }\end{array}$ & Agree & $\begin{array}{c}\text { Strongly } \\
\text { Agree }\end{array}$ \\
\hline $\begin{array}{l}\text { The ASP } \\
\text { course } \\
\text { CASE lesson } \\
\text { plans are } \\
\text { user friendly } \\
\text { to anyone } \\
\text { who tries to } \\
\text { use them. }\end{array}$ & O & 0 & 0 & O & 0 & O \\
\hline $\begin{array}{l}\text { The ASP } \\
\text { course } \\
\text { CASE lesson } \\
\text { plans contain } \\
\text { the material } \\
\text { to be taught } \\
\text { in each } \\
\text { lesson. }\end{array}$ & O & 0 & 0 & O & 0 & O \\
\hline $\begin{array}{l}\text { The ASP } \\
\text { course } \\
\text { CASE lesson } \\
\text { plans contain } \\
\text { the material } \\
\text { to be taught } \\
\text { in each unit. }\end{array}$ & O & 0 & 0 & O & 0 & 0 \\
\hline $\begin{array}{l}\text { The ASP } \\
\text { course } \\
\text { CASE lesson } \\
\text { plans overall } \\
\text { contain the } \\
\text { needed } \\
\text { amount of } \\
\text { material. }\end{array}$ & 0 & 0 & 0 & 0 & 0 & O \\
\hline
\end{tabular}


Answer If-- Directions: Please select the CASE curriculum courses in which you have been trained. If you have been trained in multiple courses, please select all that apply... Agricultural Science- Plant Is Selected

Course: Principles of Agricultural Science- Plant (ASP)

Q26 Directions: Using the scale below, please compare the Principles of Agricultural Science- Plant (ASP) course CASE curriculum to traditional classroom instruction on the following areas. For each of the following areas, the CASE Introduction to Principles of Agricultural Science- Plant (ASP) is when compared to previous curriculum.

\begin{tabular}{|l|c|c|c|c|c|} 
& $\begin{array}{c}\text { Definitely } \\
\text { Inferior }\end{array}$ & Inferior & Equal To & Superior & $\begin{array}{c}\text { Definitely } \\
\text { Superior }\end{array}$ \\
\hline $\begin{array}{l}\text { Classroom } \\
\text { and } \\
\text { laboratory }\end{array}$ & 0 & 0 & 0 & 0 & 0 \\
$\begin{array}{l}\text { FFA and } \\
\text { leadership }\end{array}$ & 0 & 0 & 0 & 0 & 0 \\
$\begin{array}{l}\text { Supervised } \\
\text { Agriculture } \\
\begin{array}{l}\text { Experiences } \\
\text { (SAE) }\end{array}\end{array}$ & 0 & 0 & 0 & 0 & 0 \\
$\begin{array}{l}\text { All aspects } \\
\text { of an } \\
\text { Agricultural } \\
\text { education }\end{array}$ & 0 & 0 & 0 & 0 & 0 \\
Program & & & & & \\
\hline
\end{tabular}


Answer If--Directions: Please select the CASE curriculum courses in which you have been trained. If you have been trained in multiple courses, please select all that apply...

\section{Agricultural Science- Plant Is Selected}

Course: Principles of Agricultural Science- Plant (ASP)

Q27 Directions: Using the scale below, please indicate the degree to which you agree or disagree with the following statements about the students' views of the CASE curriculum Principles of Agricultural Science- Plant (ASP) course.

\begin{tabular}{|l|l|l|l|l|l|l|} 
& $\begin{array}{l}\text { Strongly } \\
\text { Disagree }\end{array}$ & Disagree & $\begin{array}{l}\text { Somewhat } \\
\text { Disagree }\end{array}$ & $\begin{array}{c}\text { Somewhat } \\
\text { Agree }\end{array}$ & Agree & $\begin{array}{c}\text { Strongly } \\
\text { Agree }\end{array}$ \\
\hline $\begin{array}{l}\text { Students } \\
\text { enjoyed the } \\
\text { creativity } \\
\text { of the ASP } \\
\text { course } \\
\text { lessons. }\end{array}$ & 0 & 0 & 0 & 0 & 0 & 0 \\
$\begin{array}{l}\text { Students } \\
\text { enjoyed the } \\
\text { spontaneity } \\
\text { of the ASP } \\
\text { course } \\
\text { lessons. }\end{array}$ & 0 & 0 & 0 & 0 & 0 & 0 \\
$\begin{array}{l}\text { Students } \\
\text { enjoyed the } \\
\text { ASP } \\
\text { course. }\end{array}$ & 0 & 0 & 0 & 0 & 0 \\
\hline
\end{tabular}

Answer If --Directions: Please select the CASE curriculum courses in which you have been trained. If you have been trained in multiple courses, please select all that apply... Agricultural Science- Plant Is Selected

Q28 Please slide the bar to indicate the level of positive excitement of your students as you implemented the ASP course CASE Curriculum. 0 represents the lowest level of excitement and 100 represents the highest level of excitement.

Students positive excitement at the beginning of the course.

Students positive excitement in the middle of the course.

Students positive excitement at the end of the course. 
Answer If --Directions: Please select the CASE curriculum courses in which you have been trained. If you have been trained in multiple course, please select all that apply... Agricultural Power and Technology Is Selected

Q30 Did you teach the Agricultural Power and Technology (APT) course CASE curriculum in a classroom?

$\mathrm{O}$ Yes

O No

If Yes Is Selected, Then Skip To Course: Agricultural Power and Technology,

Directions: Using the scale below, please indicate the degree to which you agree or disagree with the following statements about the 10 day CASE training on the Agricultural Power and Technology (APT) course. ...If No Is Selected, Then Skip To End of Block (Demographics)

Answer If --Directions: Please select the CASE curriculum courses in which you have been trained. If you have been trained in multiple course, please select all that apply... Agricultural Power and Technology Is Selected

Course: Agricultural Power and Technology (APT)

Q31 Directions: Using the scale below, please indicate the degree to which you agree or disagree with the following statements about the 10 day CASE training on the Agricultural Power and Technology (APT) course. 


\begin{tabular}{|c|c|c|c|c|c|c|}
\hline & $\begin{array}{l}\text { Strongly } \\
\text { Disagree }\end{array}$ & Disagree & $\begin{array}{l}\text { Somewhat } \\
\text { Disagree }\end{array}$ & $\begin{array}{c}\text { Somewhat } \\
\text { Agree }\end{array}$ & Agree & $\begin{array}{c}\text { Strongly } \\
\text { Agree }\end{array}$ \\
\hline $\begin{array}{l}\text { The CASE } \\
\text { training } \\
\text { prepared } \\
\text { individuals } \\
\text { to } \\
\text { implement } \\
\text { the APT } \\
\text { CASE } \\
\text { course. }\end{array}$ & O & 0 & O & 0 & 0 & 0 \\
\hline $\begin{array}{l}\text { The CASE } \\
\text { training } \\
\text { prepared } \\
\text { individuals } \\
\text { to use the } \\
\text { CASE } \\
\text { curriculum } \\
\text { APT } \\
\text { course } \\
\text { lesson } \\
\text { plans. }\end{array}$ & 0 & 0 & 0 & 0 & 0 & . \\
\hline $\begin{array}{l}\text { The CASE } \\
\text { training } \\
\text { adequately } \\
\text { prepared } \\
\text { individuals } \\
\text { to use the } \\
\text { APT } \\
\text { course } \\
\text { CASE } \\
\text { Power } \\
\text { Points } \\
\text { included in } \\
\text { the } \\
\text { curriculum. }\end{array}$ & 0 & 0 & 0 & 0 & 0 & 0 \\
\hline
\end{tabular}


Answer If --Directions: Please select the CASE curriculum courses in which you have been trained. If you have been trained in multiple course, please select all that apply... Agricultural Power and Technology Is Selected

Q32 Did you require assistance after the training at the CASE institute when implementing the curriculum in the classroom?

$\mathrm{O}$ Yes

O No

If Yes Is Selected, Then Skip To Course: Agricultural Power and Technology,

Directions: Using the scale below, please indicate the degree to which you agree or disagree with the following statements about professional development with CASE staff and lead teachers that followed the Agricultural Power and Technology (APT) course CASE training....If No Is Selected, Then Skip To Course: Agricultural Power and Technology, Directions: Using the scale below, please indicate the degree to which you agree or disagree with the following statements about the use of the CASE curriculum following the training for the Agricultural Power and Technology (APT) course. These statements are based on the use of the Agricultural Power and Technology (APT) course in the classroom following the training...

Answer If --Directions: Please select the CASE curriculum courses in which you have been trained. If you have been trained in multiple course, please select all that apply... Agricultural Power and Technology Is Selected

Course: Agricultural Power and Technology (APT)

Q33 Directions: Using the scale below, please indicate the degree to which you agree or disagree with the following statements about professional development with CASE staff and lead teachers that followed the Agricultural Power and Technology (APT) course CASE training. 


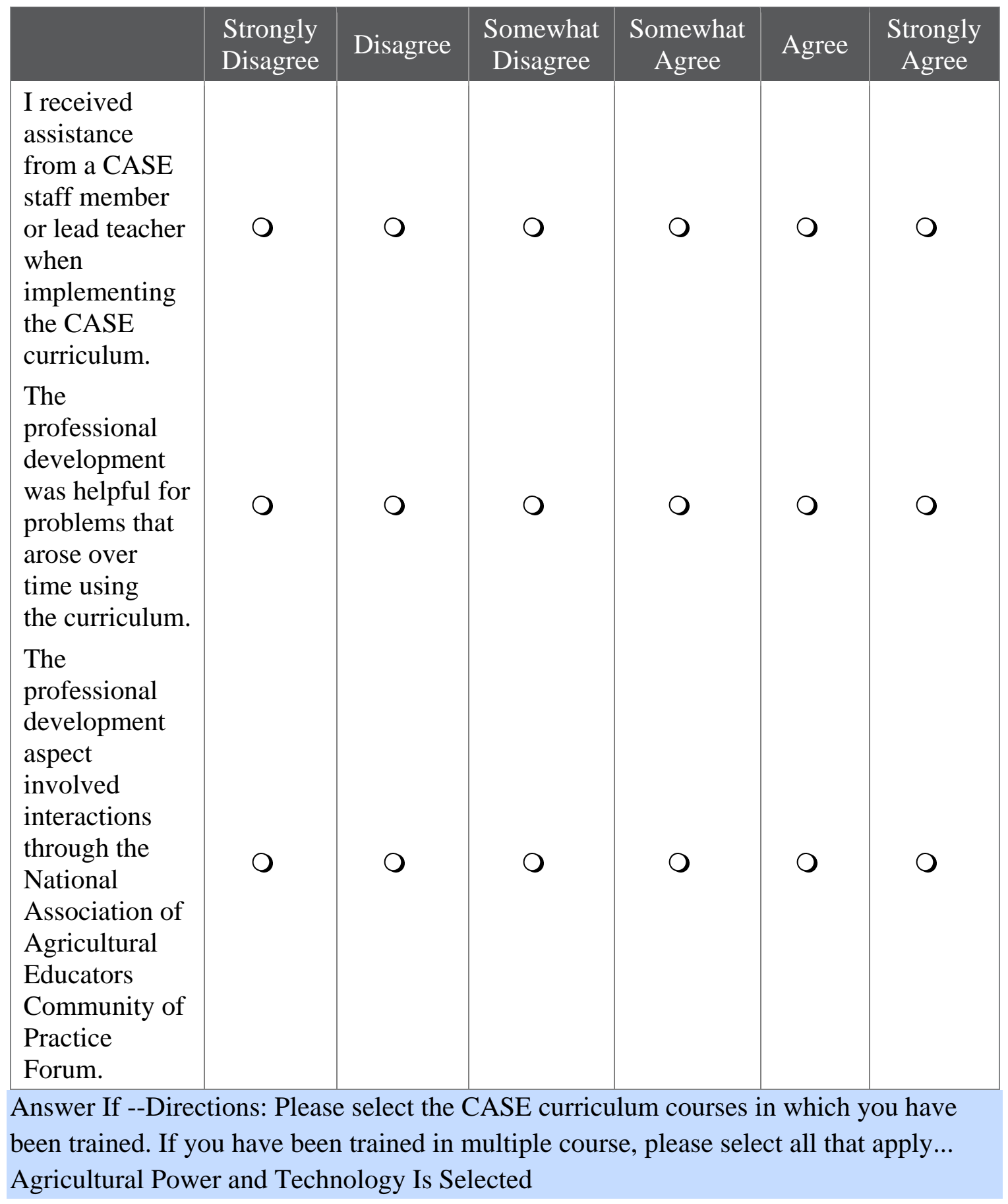

Course: Agricultural Power and Technology (APT)

Q34 Directions: Using the scale below, please indicate the degree to which you agree or disagree with the following statements about the use of the CASE curriculum following the training for the Agricultural Power and Technology (APT) course. These statements 
are based on the use of the Agricultural Power and Technology (APT) course in the classroom following the training.

\begin{tabular}{|c|c|c|c|c|c|c|}
\hline & $\begin{array}{l}\text { Strongly } \\
\text { Disagree }\end{array}$ & Disagree & $\begin{array}{l}\text { Somewhat } \\
\text { Disagree }\end{array}$ & $\begin{array}{c}\text { Somewhat } \\
\text { Agree }\end{array}$ & Agree & $\begin{array}{c}\text { Strongly } \\
\text { Agree }\end{array}$ \\
\hline $\begin{array}{l}\text { I was } \\
\text { comfortable } \\
\text { using the } \\
\text { curriculum } \\
\text { in the } \\
\text { classroom. }\end{array}$ & 0 & 0 & 0 & O & 0 & 0 \\
\hline $\begin{array}{l}\text { My } \\
\text { knowledge } \\
\text { and skills } \\
\text { of the } \\
\text { material } \\
\text { increased } \\
\text { from the } \\
\text { training. }\end{array}$ & 0 & 0 & 0 & 0 & 0 & 0 \\
\hline $\begin{array}{l}\text { The } \\
\text { training led } \\
\text { to a } \\
\text { positive } \\
\text { change in } \\
\text { my } \\
\text { instruction. }\end{array}$ & 0 & 0 & 0 & 0 & 0 & 0 \\
\hline $\begin{array}{l}\text { My } \\
\text { students } \\
\text { learning } \\
\text { improved. }\end{array}$ & 0 & 0 & 0 & 0 & 0 & 0 \\
\hline
\end{tabular}

Answer If --Directions: Please select the CASE curriculum courses in which you have been trained. If you have been trained in multiple course, please select all that apply... Agricultural Power and Technology Is Selected

Course: Agricultural Power and Technology (APT)

Q35 Directions: Using the scale below, please indicate the degree to which you agree or disagree with the following statements about the Agricultural Power and Technology (APT) course lesson plans and supporting materials. 


\begin{tabular}{|c|c|c|c|c|c|c|}
\hline & $\begin{array}{l}\text { Strongly } \\
\text { Disagree }\end{array}$ & Disagree & $\begin{array}{l}\text { Somewhat } \\
\text { Disagree }\end{array}$ & $\begin{array}{l}\text { Somewhat } \\
\text { Agree }\end{array}$ & Agree & $\begin{array}{c}\text { Strongly } \\
\text { Agree }\end{array}$ \\
\hline $\begin{array}{l}\text { The APT } \\
\text { course } \\
\text { CASE lesson } \\
\text { plans are } \\
\text { user friendly } \\
\text { to anyone } \\
\text { who tries to } \\
\text { use them. }\end{array}$ & O & O & 0 & O & 0 & O \\
\hline $\begin{array}{l}\text { The APT } \\
\text { course } \\
\text { CASE lesson } \\
\text { plans contain } \\
\text { the material } \\
\text { to be taught } \\
\text { in each } \\
\text { lesson. }\end{array}$ & O & 0 & 0 & O & 0 & 0 \\
\hline $\begin{array}{l}\text { The APT } \\
\text { course } \\
\text { CASE lesson } \\
\text { plans contain } \\
\text { the material } \\
\text { to be taught } \\
\text { in each unit. }\end{array}$ & O & 0 & 0 & $\mathrm{O}$ & 0 & 0 \\
\hline $\begin{array}{l}\text { The APT } \\
\text { course } \\
\text { CASE lesson } \\
\text { plans overall } \\
\text { contain the } \\
\text { needed } \\
\text { amount of } \\
\text { material. }\end{array}$ & 0 & 0 & 0 & 0 & 0 & 0 \\
\hline
\end{tabular}

Answer If --Directions: Please select the CASE curriculum courses in which you have been trained. If you have been trained in multiple course, please select all that apply... Agricultural Power and Technology Is Selected

Course: Agricultural Power and Technology (APT)

Q36 Directions: Using the scale below, please compare the Agricultural Power and Technology (APT) course CASE curriculum to traditional classroom instruction on the 
following areas. For each of the following areas, the CASE Introduction to Agricultural Power and Technology (APT) is when compared to previous curriculum.

\begin{tabular}{|l|c|c|c|c|c|}
\hline $\begin{array}{l}\text { Definitely } \\
\text { Inferior }\end{array}$ & Inferior & Equal To & Superior & $\begin{array}{c}\text { Definitely } \\
\text { Superior }\end{array}$ \\
\hline $\begin{array}{l}\text { laboratory } \\
\text { FFA and } \\
\text { leadership }\end{array}$ & 0 & 0 & 0 & 0 & 0 \\
$\begin{array}{l}\text { Supervised } \\
\text { Agriculture } \\
\text { Experiences } \\
\text { (SAE) }\end{array}$ & 0 & 0 & 0 & 0 & 0 \\
$\begin{array}{l}\text { All aspects } \\
\text { of an } \\
\text { Agricultural } \\
\text { education }\end{array}$ & 0 & 0 & 0 & 0 & 0 \\
Program & 0 & & & & \\
\hline
\end{tabular}

Answer If --Directions: Please select the CASE curriculum courses in which you have been trained. If you have been trained in multiple course, please select all that apply... Agricultural Power and Technology Is Selected

Course: Introduction to Agricultural Power and Technology (APT)

Q37 Directions: Using the scale below, please indicate the degree to which you agree or disagree with the following statements about the students' views of the CASE curriculum Agricultural Power and Technology (APT) course. 


\begin{tabular}{|c|c|c|c|c|c|c|}
\hline & $\begin{array}{l}\text { Strongly } \\
\text { Disagree }\end{array}$ & Disagree & $\begin{array}{c}\text { Somewhat } \\
\text { Disagree }\end{array}$ & $\begin{array}{c}\text { Somewhat } \\
\text { Agree }\end{array}$ & Agree & $\begin{array}{c}\text { Strongly } \\
\text { Agree }\end{array}$ \\
\hline $\begin{array}{l}\text { Students } \\
\text { enjoyed the } \\
\text { creativity } \\
\text { of the APT } \\
\text { course } \\
\text { lessons. }\end{array}$ & 0 & 0 & 0 & O & O & O \\
\hline $\begin{array}{l}\text { Students } \\
\text { enjoyed the } \\
\text { spontaneity } \\
\text { of the APT } \\
\text { course } \\
\text { lessons. }\end{array}$ & 0 & O & 0 & O & O & 0 \\
\hline $\begin{array}{l}\text { Students } \\
\text { enjoyed the } \\
\text { APT } \\
\text { course. }\end{array}$ & 0 & O & 0 & 0 & 0 & O \\
\hline
\end{tabular}

Answer If --Directions: Please select the CASE curriculum courses in which you have been trained. If you have been trained in multiple course, please select all that apply... Agricultural Power and Technology Is Selected

Q38 Please slide the bar to indicate the level of positive excitement of your students as you implemented the APT course CASE Curriculum. 0 represents the lowest level of excitement and 100 represents the highest level of excitement.

Students positive excitement at the beginning of the course. Students positive excitement in the middle of course. Students positive excitement at the end of the course.

Answer If --Directions: Please select the CASE curriculum courses in which you have been trained. If you have been trained in multiple courses, please select all that apply... Natural Resources and Ecology Is Selected

Q39 Did you teach the Natural Resources and Ecology (NRE) course CASE curriculum in a classroom?
$\mathrm{O}$ Yes
O No

If Yes Is Selected, Then Skip To Course: Natural Resources and Ecology,

Directions: Using the scale below, please indicate the degree to which you agree or disagree with the following statements about the 10 day CASE training on the Natural Resources and Ecology (NRE) course.....If No Is Selected, Then Skip To End of Block (Demographics) 
Answer If --Directions: Please select the CASE curriculum courses in which you have been trained. If you have been trained in multiple courses, please select all that apply...

Natural Resources and Ecology Is Selected

Course: Natural Resources and Ecology (NRE)

Q40 Directions: Using the scale below, please indicate the degree to which you agree or disagree with the following statements about the 10 day CASE training on the Natural Resources and Ecology (NRE) course.

\begin{tabular}{|c|c|c|c|c|c|c|}
\hline & $\begin{array}{l}\text { Strongly } \\
\text { Disagree }\end{array}$ & Disagree & $\begin{array}{c}\text { Somewhat } \\
\text { Disagree }\end{array}$ & $\begin{array}{c}\text { Somewhat } \\
\text { Agree }\end{array}$ & Agree & $\begin{array}{c}\text { Strongly } \\
\text { Agree }\end{array}$ \\
\hline $\begin{array}{l}\text { The CASE } \\
\text { training } \\
\text { prepared } \\
\text { individuals } \\
\text { to } \\
\text { implement } \\
\text { the NRE } \\
\text { CASE } \\
\text { course. }\end{array}$ & 0 & O & 0 & O & 0 & O \\
\hline $\begin{array}{l}\text { The CASE } \\
\text { training } \\
\text { prepared } \\
\text { individuals } \\
\text { to use the } \\
\text { CASE } \\
\text { curriculum } \\
\text { NRE } \\
\text { course } \\
\text { lesson } \\
\text { plans. }\end{array}$ & 0 & O & 0 & O & O & O \\
\hline $\begin{array}{l}\text { The CASE } \\
\text { training } \\
\text { adequately } \\
\text { prepared } \\
\text { individuals } \\
\text { to use the } \\
\text { NRE } \\
\text { course } \\
\text { CASE } \\
\text { Power } \\
\text { Points } \\
\text { included in } \\
\text { the } \\
\text { curriculum. }\end{array}$ & 0 & O & O & O & O & O \\
\hline
\end{tabular}


Answer If --Directions: Please select the CASE curriculum courses in which you have been trained. If you have been trained in multiple courses, please select all that apply... Natural Resources and Ecology Is Selected

Q41 Did you require assistance after the training at the CASE institute when implementing the curriculum in the classroom?

$\mathrm{O}$ Yes

No

If Yes Is Selected, Then Skip To Course: Natural Resources and Ecology,

Directions: Using the scale below, please indicate the degree to which

you agree or disagree with the following statements about professional development with

CASE staff and lead teachers that followed the Natural Resources and Ecology (NRE)

course CASE training....If No Is Selected, Then Skip To Course: Natural Resources and

Ecology, Directions: Using the scale below, please indicate the degree to which

you agree or disagree with the following statements about the use of the CASE

curriculum following the training for the Natural Resources and Ecology (NRE) course.

These statements are based on the use of the Natural Resources and Ecology

(NRE) course in the classroom following the training....

Answer If --Directions: Please select the CASE curriculum courses in which you have been trained. If you have been trained in multiple courses, please select all that apply...

Natural Resources and Ecology Is Selected

Course: Natural Resources and Ecology (NRE)

Q42 Directions: Using the scale below, please indicate the degree to which you agree or disagree with the following statements about professional development with CASE staff and lead teachers that followed the Natural Resources and Ecology (NRE) course CASE training. 


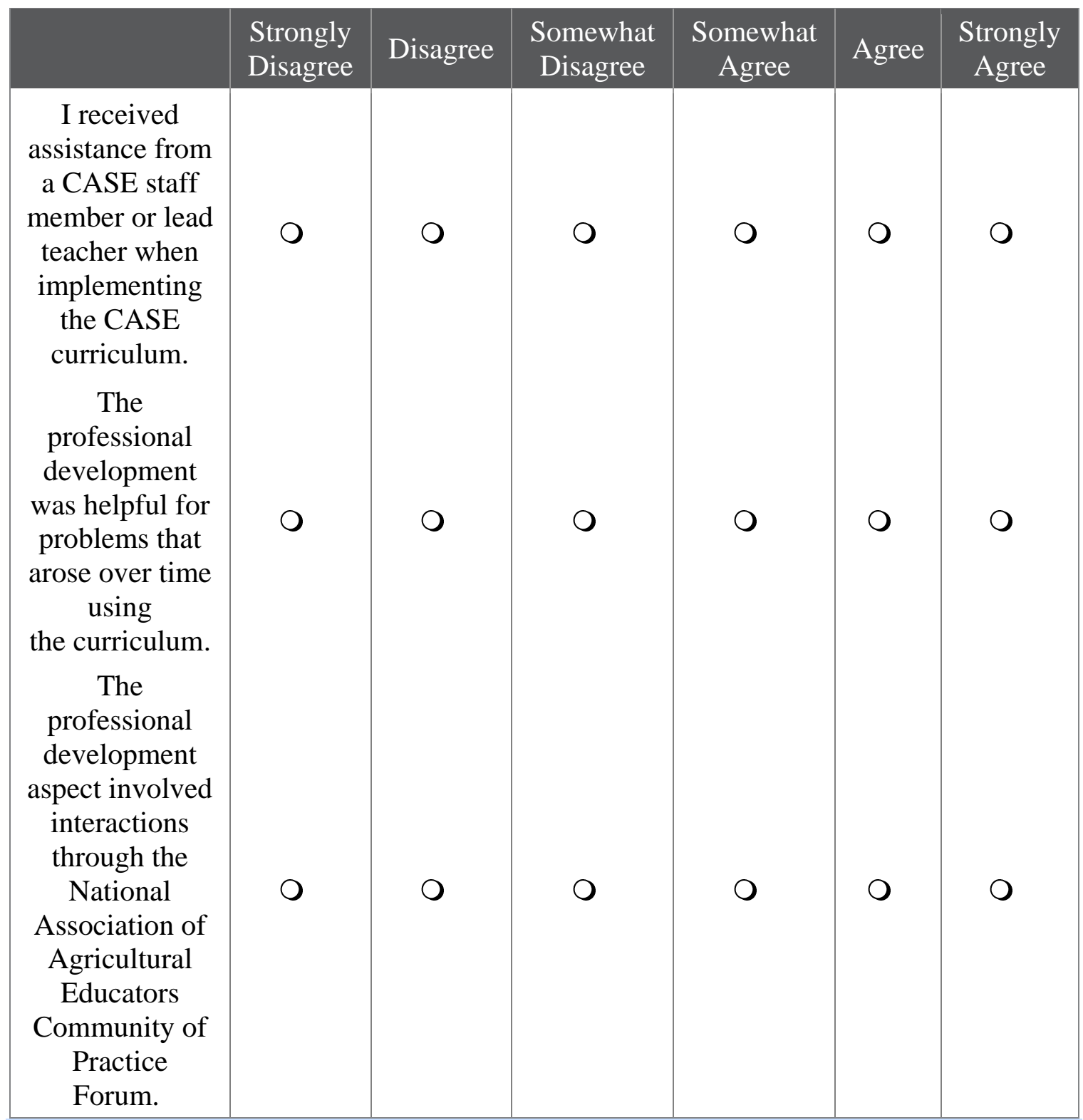

Answer If --Directions: Please select the CASE curriculum courses in which you have been trained. If you have been trained in multiple courses, please select all that apply... Natural Resources and Ecology Is Selected

Course: Natural Resources and Ecology (NRE)

Q43 Directions: Using the scale below, please indicate the degree to which you agree or disagree with the following statements about the use of the CASE curriculum following the training for the Natural Resources and Ecology (NRE) course. These statements are 
based on the use of the Natural Resources and Ecology (NRE) course in the classroom following the training.

\begin{tabular}{|c|c|c|c|c|c|c|}
\hline & $\begin{array}{l}\text { Strongly } \\
\text { Disagree }\end{array}$ & Disagree & $\begin{array}{c}\text { Somewhat } \\
\text { Disagree }\end{array}$ & $\begin{array}{c}\text { Somewhat } \\
\text { Agree }\end{array}$ & Agree & $\begin{array}{c}\text { Strongly } \\
\text { Agree }\end{array}$ \\
\hline $\begin{array}{l}\text { I was } \\
\text { comfortable } \\
\text { using the } \\
\text { curriculum } \\
\text { in the } \\
\text { classroom. }\end{array}$ & O & 0 & 0 & 0 & 0 & O \\
\hline $\begin{array}{l}\text { My } \\
\text { knowledge } \\
\text { and skills } \\
\text { of the } \\
\text { material } \\
\text { increased } \\
\text { from the } \\
\text { training. }\end{array}$ & O & 0 & 0 & 0 & 0 & O \\
\hline $\begin{array}{l}\text { The } \\
\text { training led } \\
\text { to a } \\
\text { positive } \\
\text { change in } \\
\text { my } \\
\text { instruction. }\end{array}$ & O & 0 & 0 & 0 & 0 & O \\
\hline $\begin{array}{l}\text { My } \\
\text { students } \\
\text { learning } \\
\text { improved. }\end{array}$ & 0 & 0 & 0 & 0 & 0 & 0 \\
\hline
\end{tabular}

Answer If --Directions: Please select the CASE curriculum courses in which you have been trained. If you have been trained in multiple courses, please select all that apply... Natural Resources and Ecology Is Selected

Course: Natural Resources and Ecology (NRE)

Q44 Directions: Using the scale below, please indicate the degree to which you agree or disagree with the following statements about the Natural Resources and Ecology (NRE) course lesson plans and supporting materials. 


\begin{tabular}{|c|c|c|c|c|c|c|}
\hline & $\begin{array}{l}\text { Strongly } \\
\text { Disagree }\end{array}$ & Disagree & $\begin{array}{l}\text { Somewhat } \\
\text { Disagree }\end{array}$ & $\begin{array}{l}\text { Somewhat } \\
\text { Agree }\end{array}$ & Agree & $\begin{array}{c}\text { Strongly } \\
\text { Agree }\end{array}$ \\
\hline $\begin{array}{l}\text { The NRE } \\
\text { course } \\
\text { CASE lesson } \\
\text { plans are } \\
\text { user friendly } \\
\text { to anyone } \\
\text { who tries to } \\
\text { use them. }\end{array}$ & O & O & 0 & O & 0 & O \\
\hline $\begin{array}{l}\text { The NRE } \\
\text { course } \\
\text { CASE lesson } \\
\text { plans contain } \\
\text { the material } \\
\text { to be taught } \\
\text { in each } \\
\text { lesson. }\end{array}$ & O & 0 & 0 & O & 0 & 0 \\
\hline $\begin{array}{l}\text { The NRE } \\
\text { course } \\
\text { CASE lesson } \\
\text { plans contain } \\
\text { the material } \\
\text { to be taught } \\
\text { in each unit. }\end{array}$ & O & 0 & 0 & O & 0 & $\mathrm{O}$ \\
\hline $\begin{array}{l}\text { The NRE } \\
\text { course } \\
\text { CASE lesson } \\
\text { plans overall } \\
\text { contain the } \\
\text { needed } \\
\text { amount of } \\
\text { material. }\end{array}$ & 0 & 0 & 0 & 0 & 0 & 0 \\
\hline
\end{tabular}

Answer If --Directions: Please select the CASE curriculum courses in which you have been trained. If you have been trained in multiple courses, please select all that apply...

Natural Resources and Ecology Is Selected

Course: Natural Resources and Ecology (NRE)

Q45 Directions: Using the scale below, please compare the Natural Resources and Ecology (NRE) course CASE curriculum to traditional classroom instruction on the 
following areas. For each of the following areas, the CASE Natural Resources and Ecology (NRE) is when compared to previous curriculum.

\begin{tabular}{|c|c|c|c|c|c|}
\hline & $\begin{array}{l}\text { Definitely } \\
\text { Inferior }\end{array}$ & Inferior & Equal To & Superior & $\begin{array}{c}\text { Definitely } \\
\text { Superior }\end{array}$ \\
\hline $\begin{array}{l}\text { Classroom } \\
\text { and } \\
\text { laboratory }\end{array}$ & 0 & O & 0 & 0 & O \\
\hline $\begin{array}{l}\text { FFA and } \\
\text { leadership }\end{array}$ & 0 & 0 & 0 & 0 & 0 \\
\hline $\begin{array}{l}\text { Supervised } \\
\text { Agriculture } \\
\text { Experiences } \\
\text { (SAE) }\end{array}$ & 0 & 0 & 0 & O & 0 \\
\hline $\begin{array}{l}\text { All aspects } \\
\text { of an } \\
\text { Agricultural } \\
\text { education } \\
\text { Program }\end{array}$ & 0 & 0 & 0 & 0 & 0 \\
\hline
\end{tabular}

Answer If --Directions: Please select the CASE curriculum courses in which you have been trained. If you have been trained in multiple courses, please select all that apply...

Natural Resources and Ecology Is Selected

Course: Natural Resources and Ecology (NRE)

Q46 Directions: Using the scale below, please indicate the degree to which you agree or disagree with the following statements about the students' views of the CASE curriculum Natural Resources and Ecology (NRE) course. 


\begin{tabular}{|c|c|c|c|c|c|c|}
\hline & $\begin{array}{l}\text { Strongly } \\
\text { Disagree }\end{array}$ & Disagree & $\begin{array}{c}\text { Somewhat } \\
\text { Disagree }\end{array}$ & $\begin{array}{l}\text { Somewhat } \\
\text { Agree }\end{array}$ & Agree & $\begin{array}{l}\text { Strongly } \\
\text { Agree }\end{array}$ \\
\hline $\begin{array}{l}\text { Students } \\
\text { enjoyed the } \\
\text { creativity } \\
\text { of the NRE } \\
\text { course } \\
\text { lessons. }\end{array}$ & 0 & 0 & 0 & O & 0 & O \\
\hline $\begin{array}{l}\text { Students } \\
\text { enjoyed the } \\
\text { spontaneity } \\
\text { of the NRE } \\
\text { course } \\
\text { lessons. }\end{array}$ & 0 & 0 & 0 & 0 & 0 & O \\
\hline $\begin{array}{l}\text { Students } \\
\text { enjoyed the } \\
\text { NRE } \\
\text { course. }\end{array}$ & 0 & O & 0 & O & 0 & O \\
\hline
\end{tabular}

Answer If --Directions: Please select the CASE curriculum courses in which you have been trained. If you have been trained in multiple courses, please select all that apply... Natural Resources and Ecology Is Selected

Q47 Please slide the bar to indicate the level of positive excitement of your students as you implemented the NRE course CASE Curriculum. 0 represents the lowest level of excitement and 100 represents the highest level of excitement.

Students positive excitement at the beginning of the course.

Students positive excitement in the middle of the course.

Students excitement at the end of the course.

Answer If --Directions: Please select the CASE curriculum courses in which you have been trained. If you have been trained in multiple courses, please select all that apply... Animal and Plant Biotechnology Is Selected

Q48 Did you teach the Animal and Plant Biotechnology (APB) course CASE curriculum in a classroom?
$\mathrm{O}$ Yes
O No

If Yes Is Selected, Then Skip To Course: Animal and Plant Biotechnology,

Directions: Using the scale below, please indicate the degree to which 
you agree or disagree with the following statements about the 10 day CASE training on the Animal and Plant Biotechnology (APB) course....If No Is Selected, Then Skip To End of Block (Demographics)

Answer If --Directions: Please select the CASE curriculum courses in which you have been trained. If you have been trained in multiple courses, please select all that apply... Animal and Plant Biotechnology Is Selected

Course: Animal and Plant Biotechnology (APB)

Q49 Directions: Using the scale below, please indicate the degree to which you agree or disagree with the following statements about the 10 day CASE training on the Animal and Plant Biotechnology (APB) course. 


\begin{tabular}{|c|c|c|c|c|c|c|}
\hline & $\begin{array}{l}\text { Strongly } \\
\text { Disagree }\end{array}$ & Disagree & $\begin{array}{l}\text { Somewhat } \\
\text { Disagree }\end{array}$ & $\begin{array}{c}\text { Somewhat } \\
\text { Agree }\end{array}$ & Agree & $\begin{array}{c}\text { Strongly } \\
\text { Agree }\end{array}$ \\
\hline $\begin{array}{l}\text { The CASE } \\
\text { training } \\
\text { prepared } \\
\text { individuals } \\
\text { to } \\
\text { implement } \\
\text { the APB } \\
\text { CASE } \\
\text { course. }\end{array}$ & 0 & 0 & 0 & 0 & 0 & 0 \\
\hline $\begin{array}{l}\text { The CASE } \\
\text { training } \\
\text { prepared } \\
\text { individuals } \\
\text { to use the } \\
\text { CASE } \\
\text { curriculum } \\
\text { APB } \\
\text { course } \\
\text { lesson } \\
\text { plans. }\end{array}$ & 0 & 0 & 0 & 0 & 0 & 0 \\
\hline $\begin{array}{l}\text { The CASE } \\
\text { training } \\
\text { adequately } \\
\text { prepared } \\
\text { individuals } \\
\text { to use the } \\
\text { APB } \\
\text { course } \\
\text { CASE } \\
\text { Power } \\
\text { Points } \\
\text { included in } \\
\text { the } \\
\text { curriculum. }\end{array}$ & 0 & 0 & 0 & 0 & 0 & 0 \\
\hline
\end{tabular}


Answer If --Directions: Please select the CASE curriculum courses in which you have been trained. If you have been trained in multiple courses, please select all that apply... Animal and Plant Biotechnology Is Selected

Q50 Did you require assistance after the training at the CASE institute when implementing the curriculum in the classroom?

$\mathrm{O}$ Yes

O No

If Yes Is Selected, Then Skip To Course: Animal and Plant Biotechnology,

Directions: Using the scale below, please indicate the degree to which you agree or disagree with the following statements about professional development with CASE staff and lead teachers that followed the Animal and Plant Biotechnology (APB) course CASE training....If No Is Selected, Then Skip To Course: Animal and Plant Biotechnology, Directions: Using the scale below, please indicate the degree to which you agree or disagree with the following statements about the use of the CASE curriculum following the training for the Animal and Plant Biotechnology (APB) course. These statements are based on the use of the Animal and Plant Biotechnology (APB) course in the classroom following the training...

Answer If --Directions: Please select the CASE curriculum courses in which you have been trained. If you have been trained in multiple courses, please select all that apply... Animal and Plant Biotechnology Is Selected

Course: Animal and Plant Biotechnology (APB)

Q51 Directions: Using the scale below, please indicate the degree to which you agree or disagree with the following statements about professional development with CASE staff and lead teachers that followed the Animal and Plant Biotechnology (APB) course CASE training. 


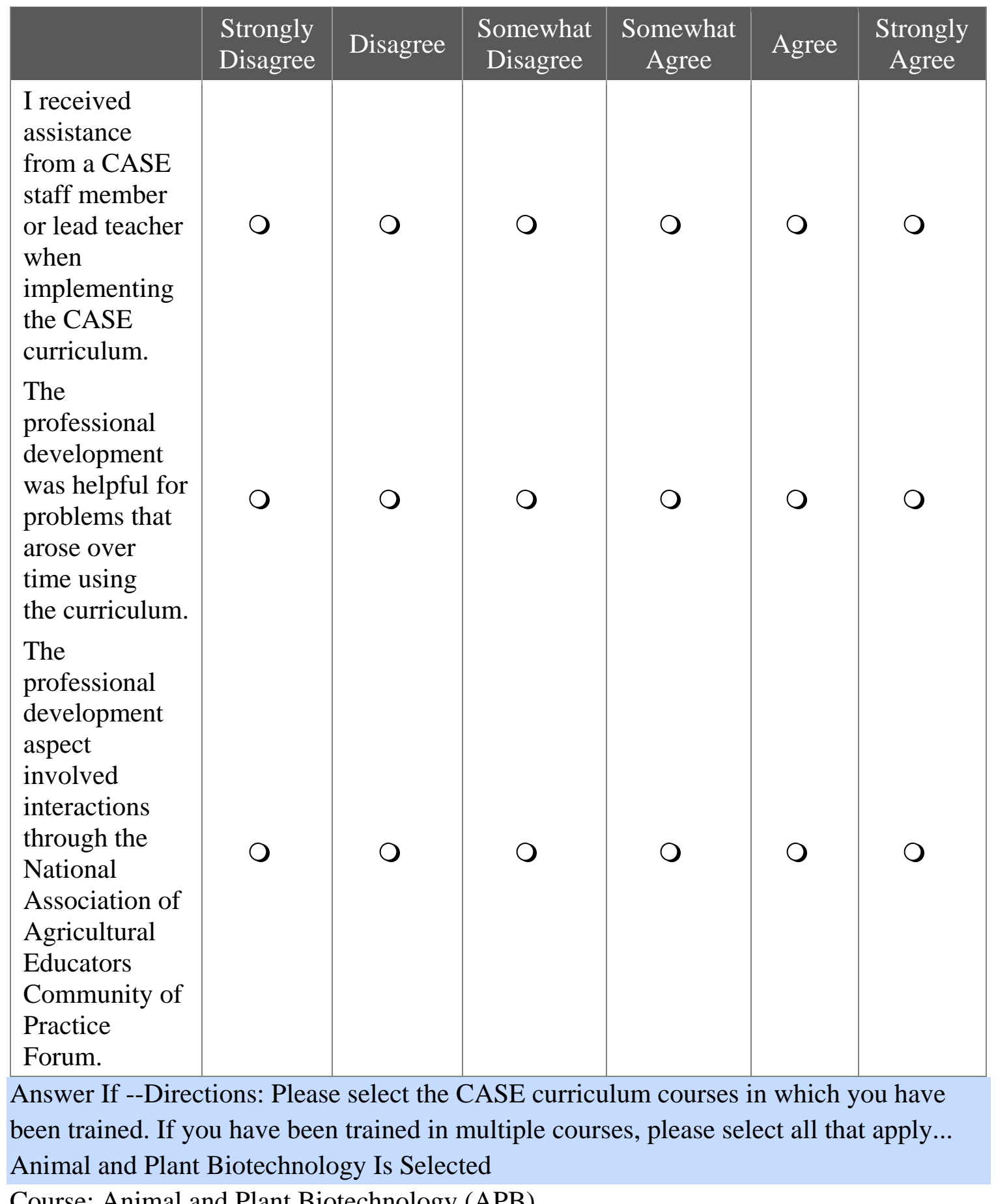

Course: Animal and Plant Biotechnology (APB)

Q52 Directions: Using the scale below, please indicate the degree to which you agree or disagree with the following statements about the use of the CASE curriculum following the training for the Animal and Plant Biotechnology (APB) course. These statements are 
based on the use of the Animal and Plant Biotechnology (APB) course in the classroom following the training.

\begin{tabular}{|c|c|c|c|c|c|c|}
\hline & $\begin{array}{l}\text { Strongly } \\
\text { Disagree }\end{array}$ & Disagree & $\begin{array}{c}\text { Somewhat } \\
\text { Disagree }\end{array}$ & $\begin{array}{c}\text { Somewhat } \\
\text { Agree }\end{array}$ & Agree & $\begin{array}{c}\text { Strongly } \\
\text { Agree }\end{array}$ \\
\hline $\begin{array}{l}\text { I was } \\
\text { comfortable } \\
\text { using the } \\
\text { curriculum } \\
\text { in the } \\
\text { classroom. }\end{array}$ & 0 & 0 & 0 & O & O & 0 \\
\hline $\begin{array}{l}\text { My } \\
\text { knowledge } \\
\text { and skills } \\
\text { of the } \\
\text { material } \\
\text { increased } \\
\text { from the } \\
\text { training. }\end{array}$ & O & 0 & 0 & O & O & 0 \\
\hline $\begin{array}{l}\text { The } \\
\text { training led } \\
\text { to a } \\
\text { positive } \\
\text { change in } \\
\text { my } \\
\text { instruction. }\end{array}$ & 0 & 0 & 0 & O & 0 & 0 \\
\hline $\begin{array}{l}\text { My } \\
\text { students } \\
\text { learning } \\
\text { improved. }\end{array}$ & 0 & 0 & 0 & 0 & O & 0 \\
\hline
\end{tabular}

Answer If --Directions: Please select the CASE curriculum courses in which you have been trained. If you have been trained in multiple courses, please select all that apply... Animal and Plant Biotechnology Is Selected

Course: Animal and Plant Biotechnology (APB)

Q53 Directions: Using the scale below, please indicate the degree to which you agree or disagree with the following statements about the Animal and Plant Biotechnology (APB) course lesson plans and supporting materials. 


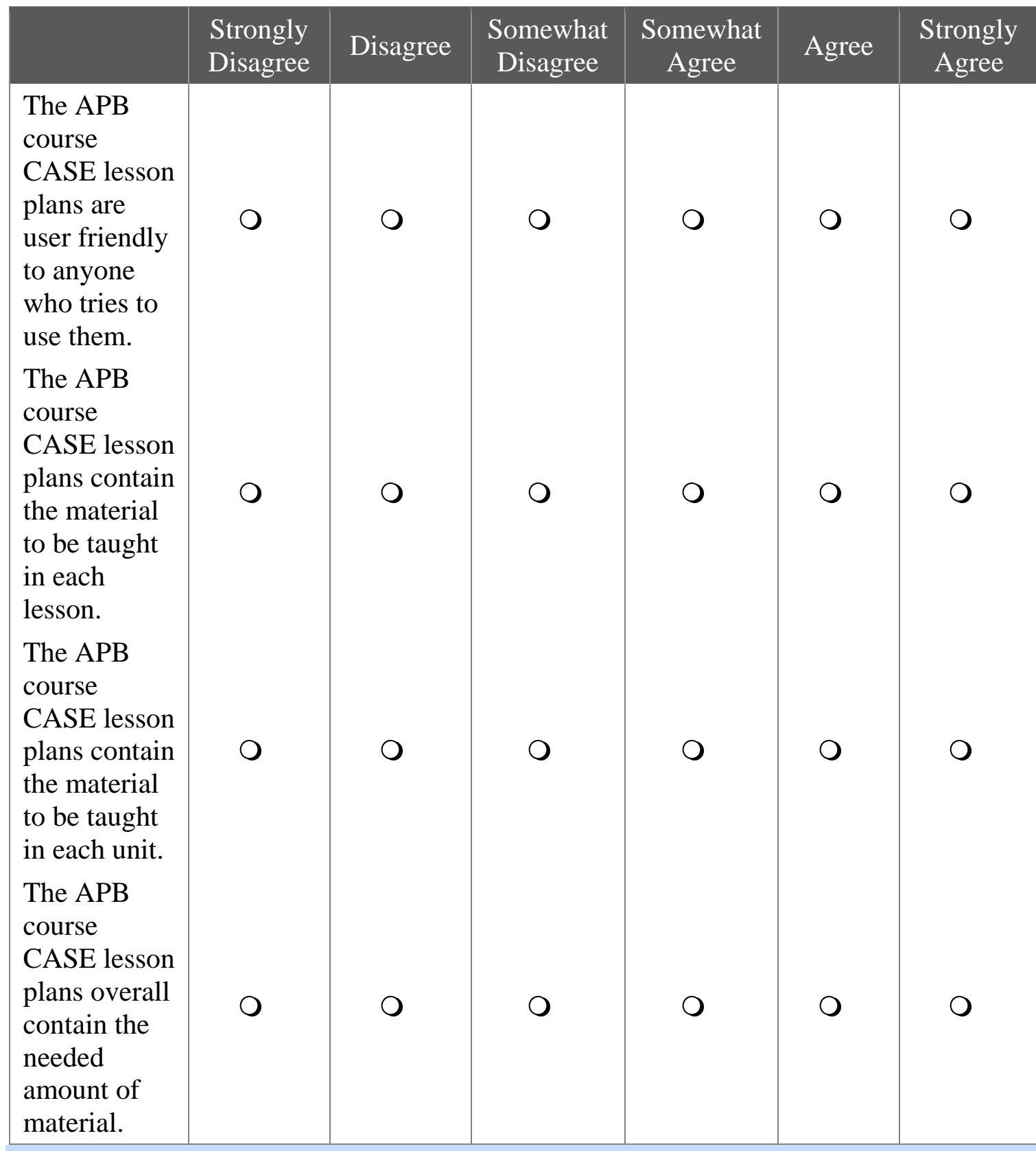

Answer If --Directions: Please select the CASE curriculum courses in which you have been trained. If you have been trained in multiple courses, please select all that apply... Animal and Plant Biotechnology Is Selected

Course: Animal and Plant Biotechnology (APB)

Q54 Directions: Using the scale below, please compare the Animal and Plant Biotechnology (APB) course CASE curriculum to traditional classroom instruction on the 
following areas. For each of the following areas, the CASE Introduction to Animal and Plant Biotechnology (APB) is when compared to previous curriculum.

\begin{tabular}{|c|c|c|c|c|c|}
\hline $\begin{array}{c}\text { Classroom } \\
\text { and } \\
\text { laboratory } \\
\text { FFA and }\end{array}$ & $\begin{array}{c}\text { Definitely } \\
\text { Inferior }\end{array}$ & Inferior & Equal To & Superior & $\begin{array}{c}\text { Definitely } \\
\text { Superior }\end{array}$ \\
$\begin{array}{c}\text { leadership } \\
\text { Supervised }\end{array}$ & 0 & 0 & 0 & 0 & 0 \\
$\begin{array}{c}\text { Agriculture } \\
\text { Experiences } \\
\text { (SAE) }\end{array}$ & 0 & 0 & 0 & 0 & 0 \\
$\begin{array}{c}\text { All aspects } \\
\text { of an }\end{array}$ & 0 & 0 & 0 & 0 & 0 \\
$\begin{array}{c}\text { Agricultural } \\
\text { education } \\
\text { Program }\end{array}$ & 0 & & 0 & \\
\hline Answ If & 0 & & & \\
\hline
\end{tabular}

Answer If --Directions: Please select the CASE curriculum courses in which you have been trained. If you have been trained in multiple courses, please select all that apply... Animal and Plant Biotechnology Is Selected Course: Animal and Plant Biotechnology (APB)

Q55 Directions: Using the scale below, please indicate the degree to which you agree or disagree with the following statements about the students' views of the CASE curriculum Animal and Plant Biotechnology (APB) course.

\begin{tabular}{|c|c|c|c|c|c|c|}
\hline $\begin{array}{c}\text { Strongly } \\
\text { Disagree }\end{array}$ & Disagree & $\begin{array}{c}\text { Somewhat } \\
\text { Disagree }\end{array}$ & $\begin{array}{c}\text { Somewhat } \\
\text { Agree }\end{array}$ & Agree & $\begin{array}{c}\text { Strongly } \\
\text { Agree }\end{array}$ \\
\hline $\begin{array}{c}\text { Students } \\
\text { creativity } \\
\text { of the APB } \\
\text { course. }\end{array}$ & O & 0 & 0 & 0 & 0 & 0 \\
$\begin{array}{c}\text { Students } \\
\text { enjoyed the } \\
\text { spontaneity } \\
\text { of the APB } \\
\text { course }\end{array}$ & 0 & 0 & 0 & 0 & 0 & 0 \\
$\begin{array}{c}\text { lessons. } \\
\text { Students } \\
\text { enjoyed the } \\
\text { APB }\end{array}$ & 0 & 0 & 0 & 0 & 0 & 0 \\
course. & 0 & & & & \\
\hline
\end{tabular}


Answer If --Directions: Please select the CASE curriculum courses in which you have been trained. If you have been trained in multiple courses, please select all that apply... Animal and Plant Biotechnology Is Selected

Q56 Please slide the bar to indicate the level of positive excitement of your students as you implemented the APB course CASE Curriculum. 0 represents the lowest level of excitement and 100 represents the highest level of excitement.

Students positive excitement at the beginning of the course.

Students positive excitement in the middle of the course.

Students positive excitement at the end of the course.

Answer If --Directions: Please select the CASE curriculum courses in which you have been trained. If you have been trained in multiple courses, please select all that apply... Food Science and Safety Is Selected

Q57 Did you teach the Food Science and Safety (FSS) course CASE curriculum in a classroom?

$\bigcirc$ Yes

O No

If Yes Is Selected, Then Skip To Course: Food Science and Safety (FSS),

Directions: Using the scale below, please indicate the degree to which

you agree or disagree with the following statements about the 10 day CASE training on the Food Science and Safety (FSS) course ...If No Is Selected, Then Skip To End of Block (Demographics)

Answer If --Directions: Please select the CASE curriculum courses in which you have been trained. If you have been trained in multiple courses, please select all that apply... Food Science and Safety Is Selected

Course: Food Science and Safety (FSS)

Q58 Directions: Using the scale below, please indicate the degree to which you agree or disagree with the following statements about the 10 day CASE training on the Food Science and Safety (FSS) course. 


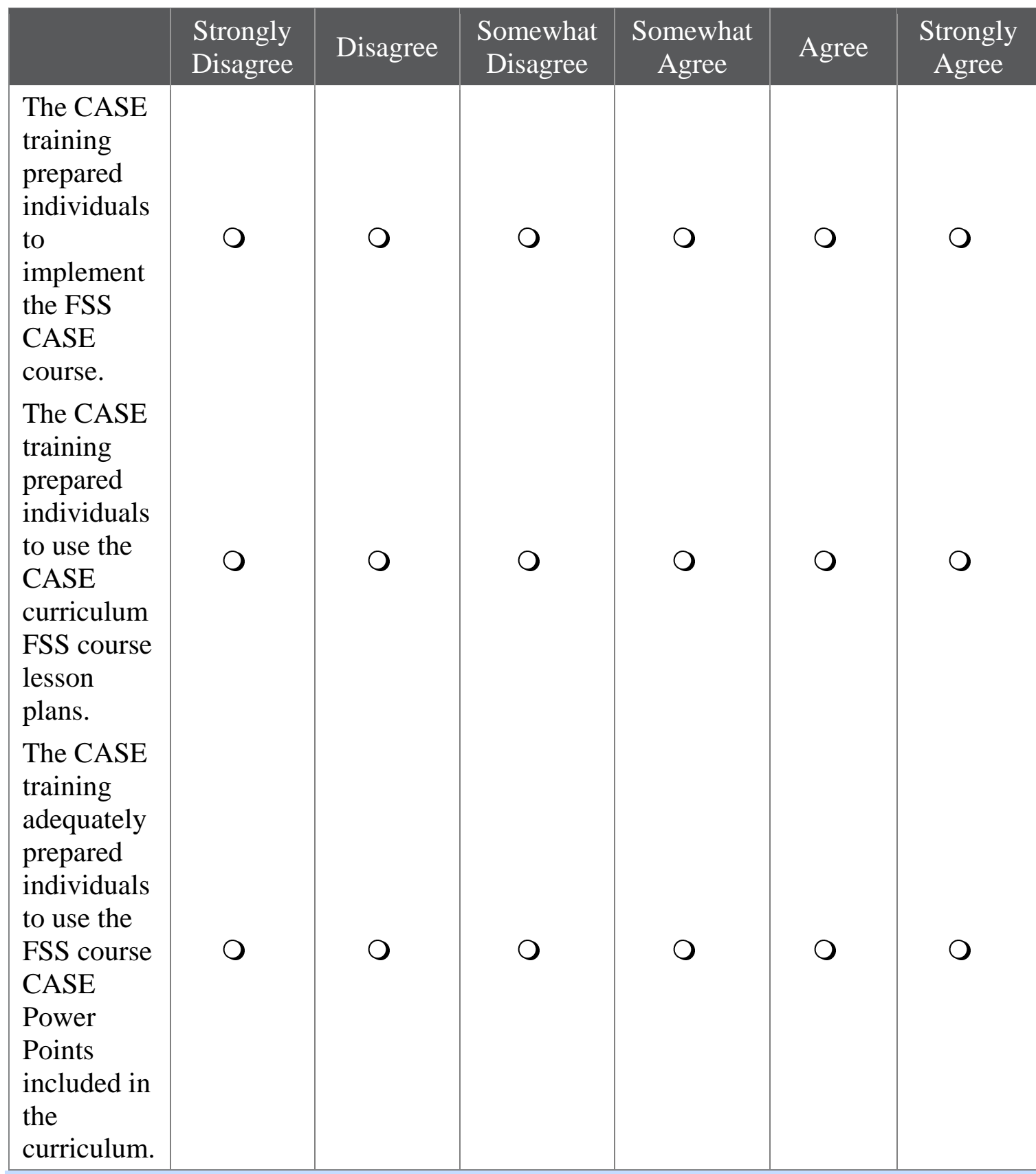

Answer If --Directions: Please select the CASE curriculum courses in which you have been trained. If you have been trained in multiple courses, please select all that apply...

Food Science and Safety Is Selected

Q59 Did you require assistance after the training at the CASE institute when implementing the curriculum in the classroom?
$\mathrm{O}$ Yes
O No

If Yes Is Selected, Then Skip To Course: Food Science and Safety, Directions: Using the scale below, please indicate the degree to which you agree or disagree with the following 
statements about professional development with CASE staff and lead teachers that followed the Food Science and Safety (FSS) course CASE training....If No Is Selected, Then Skip To Course: Food Science and Safety, Directions: Using the scale below, please indicate the degree to which you agree or disagree with the following statements about the use of the CASE curriculum following the training for the Food Science and Safety (FSS) course. These statements are based on the use of the Food Science and Safety (FSS) course in the classroom following the training....

Answer If --Directions: Please select the CASE curriculum courses in which you have been trained. If you have been trained in multiple courses, please select all that apply...

Food Science and Safety Is Selected

Course: Food Science and Safety (FSS)

Q60 Directions: Using the scale below, please indicate the degree to which you agree or disagree with the following statements about professional development with CASE staff and lead teachers that followed the Food Science and Safety (FSS) course CASE training. 


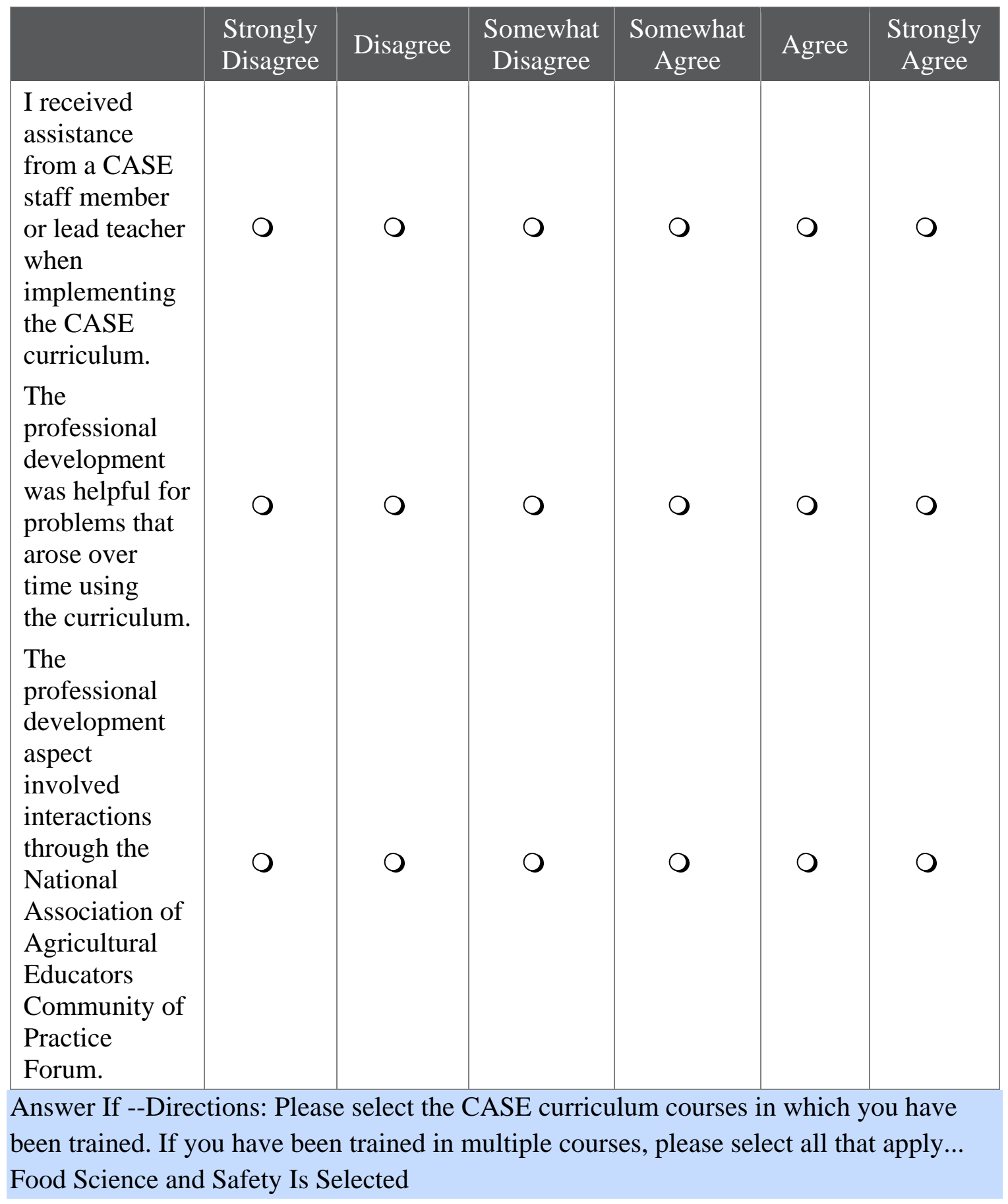

Course: Food Science and Safety (FSS)

Q61 Directions: Using the scale below, please indicate the degree to which you agree or disagree with the following statements about the use of the CASE curriculum following the training for the Food Science and Safety (FSS) course. These statements are based on 
the use of the Food Science and Safety (FSS) course in the classroom following the training.

\begin{tabular}{|c|c|c|c|c|c|c|}
\hline & $\begin{array}{l}\text { Strongly } \\
\text { Disagree }\end{array}$ & Disagree & $\begin{array}{c}\text { Somewhat } \\
\text { Disagree }\end{array}$ & $\begin{array}{c}\text { Somewhat } \\
\text { Agree }\end{array}$ & Agree & $\begin{array}{c}\text { Strongly } \\
\text { Agree }\end{array}$ \\
\hline $\begin{array}{l}\text { I was } \\
\text { comfortable } \\
\text { using the } \\
\text { curriculum } \\
\text { in the } \\
\text { classroom. }\end{array}$ & 0 & 0 & 0 & 0 & 0 & 0 \\
\hline $\begin{array}{l}\text { My } \\
\text { knowledge } \\
\text { and skills } \\
\text { of the } \\
\text { material } \\
\text { increased } \\
\text { from the } \\
\text { training. }\end{array}$ & O & 0 & 0 & 0 & 0 & O \\
\hline $\begin{array}{l}\text { The } \\
\text { training led } \\
\text { to a } \\
\text { positive } \\
\text { change in } \\
\text { my } \\
\text { instruction. }\end{array}$ & O & 0 & $\mathrm{O}$ & 0 & 0 & O \\
\hline $\begin{array}{l}\text { My } \\
\text { students } \\
\text { learning } \\
\text { improved. }\end{array}$ & O & 0 & 0 & 0 & 0 & O \\
\hline
\end{tabular}


Answer If --Directions: Please select the CASE curriculum courses in which you have been trained. If you have been trained in multiple courses, please select all that apply...

Food Science and Safety Is Selected

Course: Food Science and Safety (FSS)

Q62 Directions: Using the scale below, please indicate the degree to which you agree or disagree with the following statements about the Food Science and Safety (FSS) course lesson plans and supporting materials.

\begin{tabular}{|c|c|c|c|c|c|c|}
\hline & $\begin{array}{l}\text { Strongly } \\
\text { Disagree }\end{array}$ & Disagree & $\begin{array}{l}\text { Somewhat } \\
\text { Disagree }\end{array}$ & $\begin{array}{l}\text { Somewhat } \\
\text { Agree }\end{array}$ & Agree & $\begin{array}{c}\text { Strongly } \\
\text { Agree }\end{array}$ \\
\hline $\begin{array}{l}\text { The FSS } \\
\text { course } \\
\text { CASE lesson } \\
\text { plans are } \\
\text { user friendly } \\
\text { to anyone } \\
\text { who tries to } \\
\text { use them. }\end{array}$ & O & 0 & 0 & 0 & 0 & 0 \\
\hline $\begin{array}{l}\text { The FSS } \\
\text { course } \\
\text { CASE lesson } \\
\text { plans contain } \\
\text { the material } \\
\text { to be taught } \\
\text { in each } \\
\text { lesson. }\end{array}$ & O & 0 & 0 & O & 0 & 0 \\
\hline $\begin{array}{l}\text { The FSS } \\
\text { course } \\
\text { CASE lesson } \\
\text { plans contain } \\
\text { the material } \\
\text { to be taught } \\
\text { in each unit. }\end{array}$ & O & 0 & 0 & O & 0 & O \\
\hline $\begin{array}{l}\text { The FSS } \\
\text { course } \\
\text { CASE lesson } \\
\text { plans overall } \\
\text { contain the } \\
\text { needed } \\
\text { amount of } \\
\text { material. }\end{array}$ & O & 0 & 0 & O & 0 & 0 \\
\hline
\end{tabular}


Answer If --Directions: Please select the CASE curriculum courses in which you have been trained. If you have been trained in multiple courses, please select all that apply...

Food Science and Safety Is Selected

Course: Food Science and Safety (FSS)

Q63 Directions: Using the scale below, please compare the Food Science and Safety (FSS) course CASE curriculum to traditional classroom instruction on the following 
areas. For each of the following areas, the CASE Introduction to Food Science and Safety (FSS) is when compared to previous curriculum.

\begin{tabular}{|c|c|c|c|c|c|}
\hline & $\begin{array}{l}\text { Definitely } \\
\text { Inferior }\end{array}$ & Inferior & Equal To & Superior & $\begin{array}{c}\text { Definitely } \\
\text { Superior }\end{array}$ \\
\hline $\begin{array}{l}\text { Classroom } \\
\text { and } \\
\text { laboratory }\end{array}$ & 0 & 0 & 0 & O & 0 \\
\hline $\begin{array}{l}\text { FFA and } \\
\text { leadership }\end{array}$ & 0 & O & O & 0 & 0 \\
\hline $\begin{array}{l}\text { Supervised } \\
\text { Agriculture } \\
\text { Experiences } \\
\text { (SAE) }\end{array}$ & 0 & O & O & O & O \\
\hline $\begin{array}{l}\text { All aspects } \\
\text { of an } \\
\text { Agricultural } \\
\text { education } \\
\text { Program }\end{array}$ & 0 & $\mathrm{O}$ & 0 & $\mathrm{O}$ & 0 \\
\hline
\end{tabular}

Course: Food Science and Safety (FSS)

Q64 Directions: Using the scale below, please indicate the degree to which you agree or disagree with the following statements about the students' views of the CASE curriculum Food Science and Safety (FSS) course. 


\begin{tabular}{|c|c|c|c|c|c|c|}
\hline & $\begin{array}{l}\text { Strongly } \\
\text { Disagree }\end{array}$ & Disagree & $\begin{array}{c}\text { Somewhat } \\
\text { Disagree }\end{array}$ & $\begin{array}{c}\text { Somewhat } \\
\text { Agree }\end{array}$ & Agree & $\begin{array}{c}\text { Strongly } \\
\text { Agree }\end{array}$ \\
\hline $\begin{array}{l}\text { Students } \\
\text { enjoyed the } \\
\text { creativity } \\
\text { of the FSS } \\
\text { course } \\
\text { lessons. }\end{array}$ & 0 & 0 & 0 & 0 & O & 0 \\
\hline $\begin{array}{l}\text { Students } \\
\text { enjoyed the } \\
\text { spontaneity } \\
\text { of the FSS } \\
\text { course } \\
\text { lessons. }\end{array}$ & 0 & O & 0 & 0 & O & 0 \\
\hline $\begin{array}{l}\text { Students } \\
\text { enjoyed the } \\
\text { FSS } \\
\text { course. }\end{array}$ & 0 & O & 0 & 0 & 0 & 0 \\
\hline
\end{tabular}

Answer If --Directions: Please select the CASE curriculum courses in which you have been trained. If you have been trained in multiple courses, please select all that apply... Food Science and Safety Is Selected

Q65 Please slide the bar to indicate the level of positive excitement of your students as you implemented the FSS course CASE Curriculum. 0 represents the lowest level of excitement and 100 represents the highest level of excitement. Students positive excitement at the beginning of the course. Students positive excitement in the middle of the course. Students positive excitement at the end of the course.

Answer If --Directions: Please select the CASE curriculum courses in which you have been trained. If you have been trained in multiple courses, please select all that apply... Agricultural Research and Development Is Selected

Q66 Did you teach the Agricultural Research and Development (ARD) course CASE curriculum in a classroom?
$\mathrm{O}$ Yes
O No

If Yes Is Selected, Then Skip To Course: Agricultural Research and Development, Directions: Using the scale below, please indicate the degree to which you agree or disagree with the following statements about the 10 day CASE training on the Agricultural Research and Development (ARD) course....If No Is Selected, Then Skip To End of Block (Demographics) 
Answer If --Directions: Please select the CASE curriculum courses in which you have been trained. If you have been trained in multiple courses, please select all that apply...

Agricultural Research and Development Is Selected

Course: Agricultural Research and Development (ARD)

Q67 Directions: Using the scale below, please indicate the degree to which you agree or disagree with the following statements about the 10 day CASE training on the Agricultural Research and Development (ARD) course.

\begin{tabular}{|c|c|c|c|c|c|c|}
\hline & $\begin{array}{l}\text { Strongly } \\
\text { Disagree }\end{array}$ & Disagree & $\begin{array}{c}\text { Somewhat } \\
\text { Disagree }\end{array}$ & $\begin{array}{c}\text { Somewhat } \\
\text { Agree }\end{array}$ & Agree & $\begin{array}{c}\text { Strongly } \\
\text { Agree }\end{array}$ \\
\hline $\begin{array}{l}\text { The CASE } \\
\text { training } \\
\text { prepared } \\
\text { individuals } \\
\text { to } \\
\text { implement } \\
\text { the ARD } \\
\text { CASE } \\
\text { course. }\end{array}$ & 0 & O & 0 & O & O & O \\
\hline $\begin{array}{l}\text { The CASE } \\
\text { training } \\
\text { prepared } \\
\text { individuals } \\
\text { to use the } \\
\text { CASE } \\
\text { curriculum } \\
\text { ARD } \\
\text { course } \\
\text { lesson } \\
\text { plans. }\end{array}$ & 0 & O & 0 & O & O & O \\
\hline $\begin{array}{l}\text { The CASE } \\
\text { training } \\
\text { adequately } \\
\text { prepared } \\
\text { individuals } \\
\text { to use the } \\
\text { ARD } \\
\text { course } \\
\text { CASE } \\
\text { Power } \\
\text { Points } \\
\text { included in } \\
\text { the } \\
\text { curriculum. }\end{array}$ & 0 & O & O & O & O & O \\
\hline
\end{tabular}


Answer If --Directions: Please select the CASE curriculum courses in which you have been trained. If you have been trained in multiple courses, please select all that apply... Agricultural Research and Development Is Selected

Q68 Did you require assistance after the training at the CASE institute when implementing the curriculum in the classroom?

O Yes

O No

If Yes Is Selected, Then Skip To Course: Agricultural Research and Development, Directions: Using the scale below, please indicate the degree to which you agree or disagree with the following statements about professional development with CASE staff and lead teachers that followed the Agricultural Research and Development (ARD) course CASE training....If No Is Selected, Then Skip To Course: Agricultural Research and Development, Directions: Using the scale below, please indicate the degree to which you agree or disagree with the following statements about the use of the CASE curriculum following the training for the Agricultural Research and Development (ARD) course. These statements are based on the use of the Agricultural Research and Development (ARD) course in the classroom following the training....

Answer If --Directions: Please select the CASE curriculum courses in which you have been trained. If you have been trained in multiple courses, please select all that apply...

Agricultural Research and Development Is Selected

Course: Agricultural Research and Development (ARD)

Q69 Directions: Using the scale below, please indicate the degree to which you agree or disagree with the following statements about professional development with CASE staff and lead teachers that followed the Agricultural Research and Development (ARD) course CASE training. 


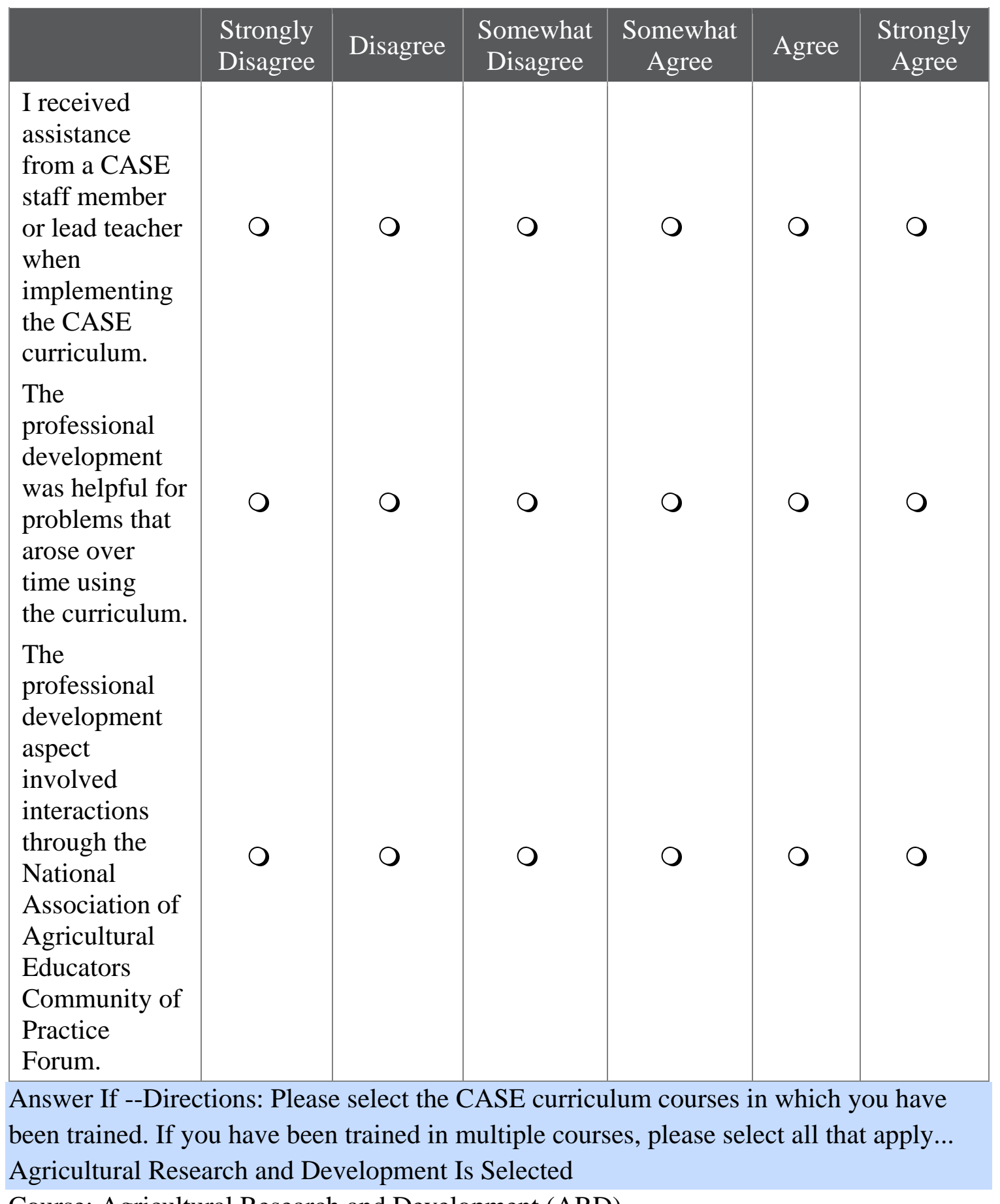

Course: Agricultural Research and Development (ARD)

Q70 Directions: Using the scale below, please indicate the degree to which you agree or disagree with the following statements about the use of the CASE curriculum following the training for the Agricultural Research and Development (ARD) course. These 
statements are based on the use of the Agricultural Research and Development (ARD) course in the classroom following the training.

\begin{tabular}{|c|c|c|c|c|c|c|}
\hline & $\begin{array}{l}\text { Strongly } \\
\text { Disagree }\end{array}$ & Disagree & $\begin{array}{c}\text { Somewhat } \\
\text { Disagree }\end{array}$ & $\begin{array}{c}\text { Somewhat } \\
\text { Agree }\end{array}$ & Agree & $\begin{array}{c}\text { Strongly } \\
\text { Agree }\end{array}$ \\
\hline $\begin{array}{l}\text { I was } \\
\text { comfortable } \\
\text { using the } \\
\text { curriculum } \\
\text { in the } \\
\text { classroom. }\end{array}$ & 0 & 0 & 0 & O & 0 & 0 \\
\hline $\begin{array}{l}\text { My } \\
\text { knowledge } \\
\text { and skills } \\
\text { of the } \\
\text { material } \\
\text { increased } \\
\text { from the } \\
\text { training. }\end{array}$ & 0 & 0 & 0 & 0 & 0 & 0 \\
\hline $\begin{array}{l}\text { The } \\
\text { training led } \\
\text { to a } \\
\text { positive } \\
\text { change in } \\
\text { my } \\
\text { instruction. }\end{array}$ & 0 & 0 & 0 & 0 & 0 & 0 \\
\hline $\begin{array}{l}\text { My } \\
\text { students } \\
\text { learning } \\
\text { improved. }\end{array}$ & 0 & 0 & 0 & 0 & 0 & 0 \\
\hline
\end{tabular}

Answer If --Directions: Please select the CASE curriculum courses in which you have been trained. If you have been trained in multiple courses, please select all that apply... Agricultural Research and Development Is Selected Course: Agricultural Research and Development (ARD)

Q71 Directions: Using the scale below, please indicate the degree to which you agree or disagree with the following statements about the Agricultural Research and Development (ARD) course lesson plans and supporting materials. 


\begin{tabular}{|c|c|c|c|c|c|c|}
\hline & $\begin{array}{l}\text { Strongly } \\
\text { Disagree }\end{array}$ & Disagree & $\begin{array}{l}\text { Somewhat } \\
\text { Disagree }\end{array}$ & $\begin{array}{l}\text { Somewhat } \\
\text { Agree }\end{array}$ & Agree & $\begin{array}{c}\text { Strongly } \\
\text { Agree }\end{array}$ \\
\hline $\begin{array}{l}\text { The ARD } \\
\text { course } \\
\text { CASE lesson } \\
\text { plans are } \\
\text { user friendly } \\
\text { to anyone } \\
\text { who tries to } \\
\text { use them. }\end{array}$ & O & O & 0 & O & 0 & O \\
\hline $\begin{array}{l}\text { The ARD } \\
\text { course } \\
\text { CASE lesson } \\
\text { plans contain } \\
\text { the material } \\
\text { to be taught } \\
\text { in each } \\
\text { lesson. }\end{array}$ & O & 0 & 0 & O & 0 & 0 \\
\hline $\begin{array}{l}\text { The ARD } \\
\text { course } \\
\text { CASE lesson } \\
\text { plans contain } \\
\text { the material } \\
\text { to be taught } \\
\text { in each unit. }\end{array}$ & O & 0 & 0 & O & 0 & $\mathrm{O}$ \\
\hline $\begin{array}{l}\text { The ARD } \\
\text { course } \\
\text { CASE lesson } \\
\text { plans overall } \\
\text { contain the } \\
\text { needed } \\
\text { amount of } \\
\text { material. }\end{array}$ & 0 & 0 & 0 & 0 & 0 & 0 \\
\hline
\end{tabular}

Answer If --Directions: Please select the CASE curriculum courses in which you have been trained. If you have been trained in multiple courses, please select all that apply... Agricultural Research and Development Is Selected

Course: Agricultural Research and Development (ARD)

Q72 Directions: Using the scale below, please compare the Agricultural Research and Development (ARD) course CASE curriculum to traditional classroom instruction on the 
following areas. For each of the following areas, the CASE Introduction to Agricultural Research and Development (ARD) is when compared to previous curriculum.

\begin{tabular}{|c|c|c|c|c|c|}
\hline & $\begin{array}{l}\text { Definitely } \\
\text { Inferior }\end{array}$ & Inferior & Equal To & Superior & $\begin{array}{c}\text { Definitely } \\
\text { Superior }\end{array}$ \\
\hline $\begin{array}{l}\text { Classroom } \\
\text { and } \\
\text { laboratory }\end{array}$ & 0 & 0 & 0 & $\bigcirc$ & 0 \\
\hline $\begin{array}{l}\text { FFA and } \\
\text { leadership }\end{array}$ & 0 & 0 & 0 & 0 & 0 \\
\hline $\begin{array}{l}\text { Supervised } \\
\text { Agriculture } \\
\text { Experiences } \\
\text { (SAE) }\end{array}$ & 0 & $\bigcirc$ & 0 & 0 & 0 \\
\hline $\begin{array}{l}\text { All aspects } \\
\text { of an } \\
\text { Agricultural } \\
\text { education } \\
\text { Program }\end{array}$ & 0 & 0 & 0 & 0 & 0 \\
\hline
\end{tabular}

Answer If --Directions: Please select the CASE curriculum courses in which you have been trained. If you have been trained in multiple courses, please select all that apply...

Agricultural Research and Development Is Selected

Course: Agricultural Research and Development (ARD)

Q73 Directions: Using the scale below, please indicate the degree to which you agree or disagree with the following statements about the students' views of the CASE curriculum Agricultural Research and Development (ARD) course. 


\begin{tabular}{|l|c|c|c|c|c|c|}
\hline & $\begin{array}{l}\text { Strongly } \\
\text { Disagree }\end{array}$ & Disagree & $\begin{array}{c}\text { Somewhat } \\
\text { Disagree }\end{array}$ & $\begin{array}{c}\text { Somewhat } \\
\text { Agree }\end{array}$ & Agree & $\begin{array}{c}\text { Strongly } \\
\text { Agree }\end{array}$ \\
\hline $\begin{array}{l}\text { Students } \\
\text { enjoyed the } \\
\text { creativity } \\
\text { of the ARD } \\
\text { course }\end{array}$ & 0 & 0 & 0 & 0 & 0 & 0 \\
$\begin{array}{l}\text { lessons. } \\
\text { Students } \\
\text { enjoyed the } \\
\text { spontaneity } \\
\text { of the ARD } \\
\text { course }\end{array}$ & 0 & 0 & 0 & 0 & 0 & 0 \\
lessons. \\
$\begin{array}{l}\text { Students } \\
\text { enjoyed the } \\
\text { ARD } \\
\text { course. }\end{array}$
\end{tabular}

Answer If --Directions: Please select the CASE curriculum courses in which you have been trained. If you have been trained in multiple courses, please select all that apply... Agricultural Research and Development Is Selected

Q74 Please slide the bar to indicate the level of positive excitement of your students as you implemented the ARD course CASE Curriculum. 0 represents the lowest level of excitement and 100 represents the highest level of excitement.

Students positive excitement at the beginning of the course.

Students positive excitement in the middle of the course.

Students positive excitement at the end of the course.

Demographics 
Directions: Please answer the following questions by selecting the best answer for you.

Q75 What is your Gender?

O Male

Female

Q76 What race best represents you?

American Indian or Alaska Native

O Asian

Black or African American

O Native Hawaiian or Pacific Islander

O White

Prefer not to answer

Other

Q77 How many years have you used the CASE curriculum?

$\begin{array}{ll}\text { O Less tha } \\ 0 & 1 \text { year } \\ 0 & 2 \text { years } \\ 0 & 3 \text { years } \\ 0 & 4 \text { years } \\ 0 & 5 \text { years } \\ 0 & 6 \text { years } \\ \bigcirc & 7 \text { years } \\ 0 & 8 \text { years } \\ 0 & 9 \text { years }\end{array}$ 
Q78 How many years have you been teaching?

Less than 1 year

O 1-4 years

5-9 years

O 10-14 years

O 15-19 years

O 20+ years 
Q79 In what state do you teach?

O Alabama
O Alaska
O Arizona
O Arkansas
O California
O Colorado
O Connecticut
O Delaware
O Florida
O Georgia
O Hawaii
O Idaho
O Illinois
O Indiana
O Iowa
O Kansas
O Kentucky
O Louisiana
O Maine
O Maryland
O Massachusetts
O Michigan
O Minnesota
O Mississippi
O Missouri
O Montana
O Nebraska
O Nevada
O New Hampshire
O New Jersey
O New Mexico
O New York
O North Carolina
O North Dakota
O Ohio
O Oklahoma
O Oregon
O Pennsylvania
O Rhode Island




South Carolina
O South Dakota
O Tennessee
O Texas
O Utah
O Vermont
O Virginia
O Washington
O West Virginia
O Wisconsin
O Wyoming

Q80 Do you currently use the CASE curriculum?

$\mathrm{O}$ Yes

O No

If Yes Is Selected, Then Skip To: What year did you attend training for courses in which you have been trained? ...If No Is Selected, Then Skip To: If no, why not?

Q81 If no, why not? 
Q82 What year did you attend training for the courses in which you have been trained?

\begin{tabular}{|c|c|c|c|c|c|c|c|c|c|}
\hline & 2007 & 2008 & 2009 & 2010 & 2011 & 2012 & 2013 & 2014 & 2015 \\
\hline $\begin{array}{l}\text { Introduction } \\
\text { to Agriculture, } \\
\text { Food and } \\
\text { Natural } \\
\text { Resources }\end{array}$ & 0 & 0 & 0 & 0 & 0 & 0 & 0 & 0 & 0 \\
\hline $\begin{array}{l}\text { Principles of } \\
\text { Agricultural } \\
\text { Science- } \\
\text { Animal }\end{array}$ & 0 & 0 & 0 & 0 & 0 & 0 & 0 & 0 & 0 \\
\hline $\begin{array}{l}\text { Principles of } \\
\text { Agricultural } \\
\text { Science- Plant }\end{array}$ & 0 & 0 & 0 & 0 & 0 & 0 & 0 & 0 & 0 \\
\hline $\begin{array}{l}\text { Agricultural } \\
\text { Power and } \\
\text { Technology }\end{array}$ & 0 & 0 & 0 & 0 & 0 & 0 & 0 & 0 & 0 \\
\hline $\begin{array}{l}\text { Natural } \\
\text { Resources and } \\
\text { Ecology }\end{array}$ & 0 & 0 & 0 & 0 & 0 & 0 & 0 & 0 & 0 \\
\hline $\begin{array}{l}\text { Animal and } \\
\text { Plant } \\
\text { Biotechnology }\end{array}$ & 0 & 0 & 0 & 0 & 0 & 0 & 0 & 0 & 0 \\
\hline $\begin{array}{l}\text { Food Science } \\
\text { and Safety }\end{array}$ & 0 & 0 & 0 & 0 & 0 & 0 & 0 & 0 & 0 \\
\hline $\begin{array}{l}\text { Agricultural } \\
\text { Research and } \\
\text { Development }\end{array}$ & 0 & 0 & 0 & 0 & 0 & 0 & 0 & 0 & 0 \\
\hline
\end{tabular}

Q83 Are you currently certified in an entire CASE pathway?

O Yes

O No

Q84 What is your highest level of education?

Bachelor's Degree

O Master's Degree

$\mathrm{PhD}$

Thank you for assisting me with my Master's Thesis research. 


\section{APPENDIX C}

Follow up Reminder Email 
Dear CASE educators:

Everyone has received my first email informing you of a study for the CASE curriculum. Thank you to those individuals who have completed the survey. To those individuals that have not, there is still time.

Your valuable input is still able to be used in this study. The study closes on 02/12/16. This study is very important and your input is vital in its success. The goal of the study is to gain views and attitudes of educators who are using the CASE curriculum and have been through training.

The results will be used to help understand how educators view the CASE curriculum. The results will be confidential and will not be able to be identified with a specific individual. Please complete the survey to ensure success of this study.

Thank you for your help in gaining knowledge on this topic, the study is important to everyone as CASE educators. This study is vital to my Masters research and I would appreciate your help by completing this survey using the link below.

Follow this link to the Survey:

$\$\{1: / /$ SurveyLink?d=Take the Survey $\}$

Or copy and paste the URL below into your internet browser:

$\$\{1: / /$ SurveyURL $\}$

Thank you for your participation.

Sincerely,

Lauren Devine

Masters Student
Dr. Stacy Gartin, Ph.D.

Professor: Agricultural Education 
APPENDIX D

Thank you Email 
Dear CASE educators:

Thank you for your participation in this survey. The results have been gathered and the survey has concluded. We greatly appreciate your participation in this study. The results of the study will be beneficial to all CASE curriculum users, future and present.

You have all helped me reach my target for over $50 \%$ of the population response rate. If you have any questions regarding the study, please email ldaub@mix.wvu.edu. Again, thank you for your help in completing this study and my Masters research.

Sincerely,

Lauren Devine Masters Student
Dr. Stacy Gartin, Ph.D.

Professor: Agricultural Education 


\section{APPENDIX E}

Open Ended Responses 


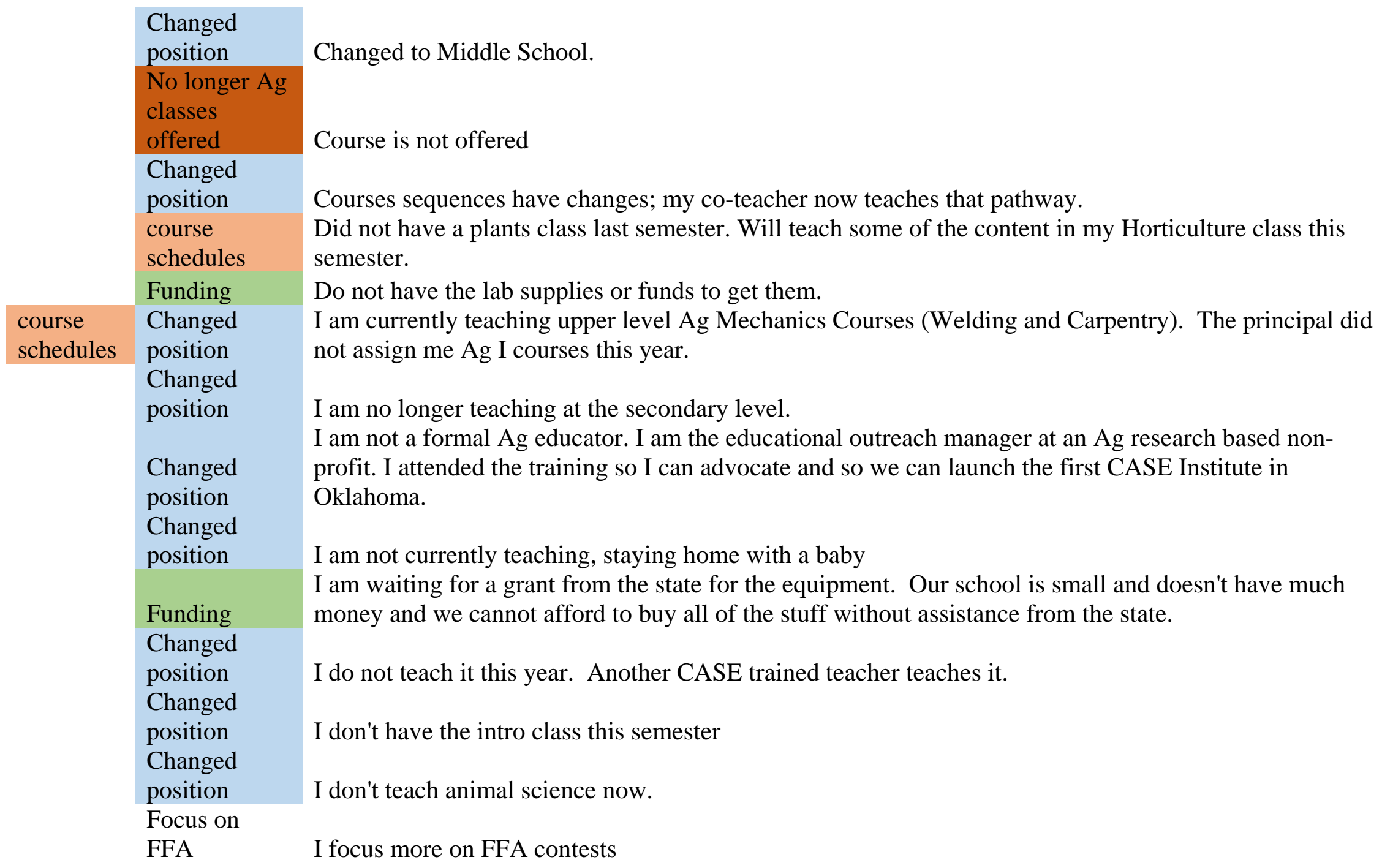




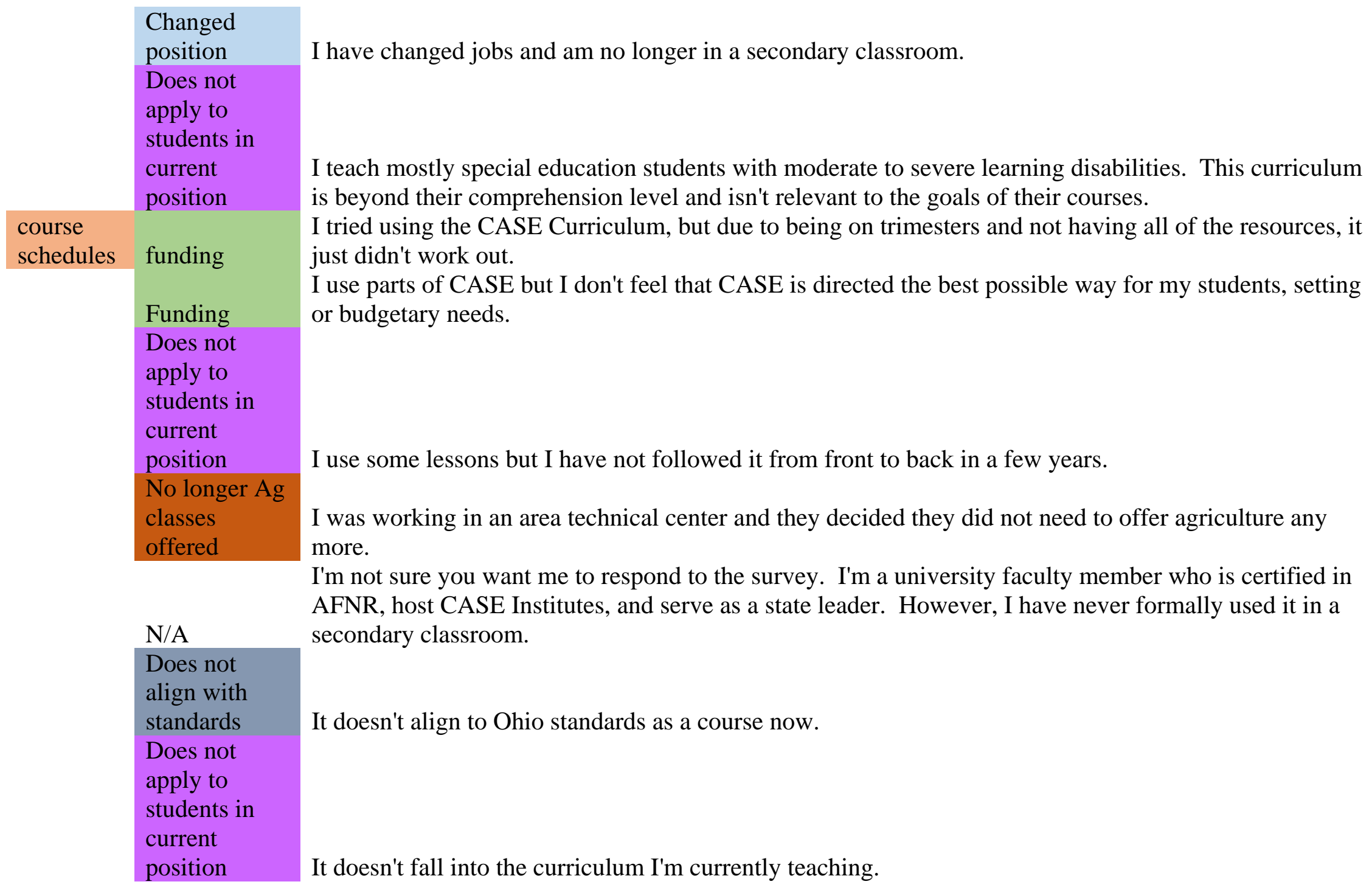




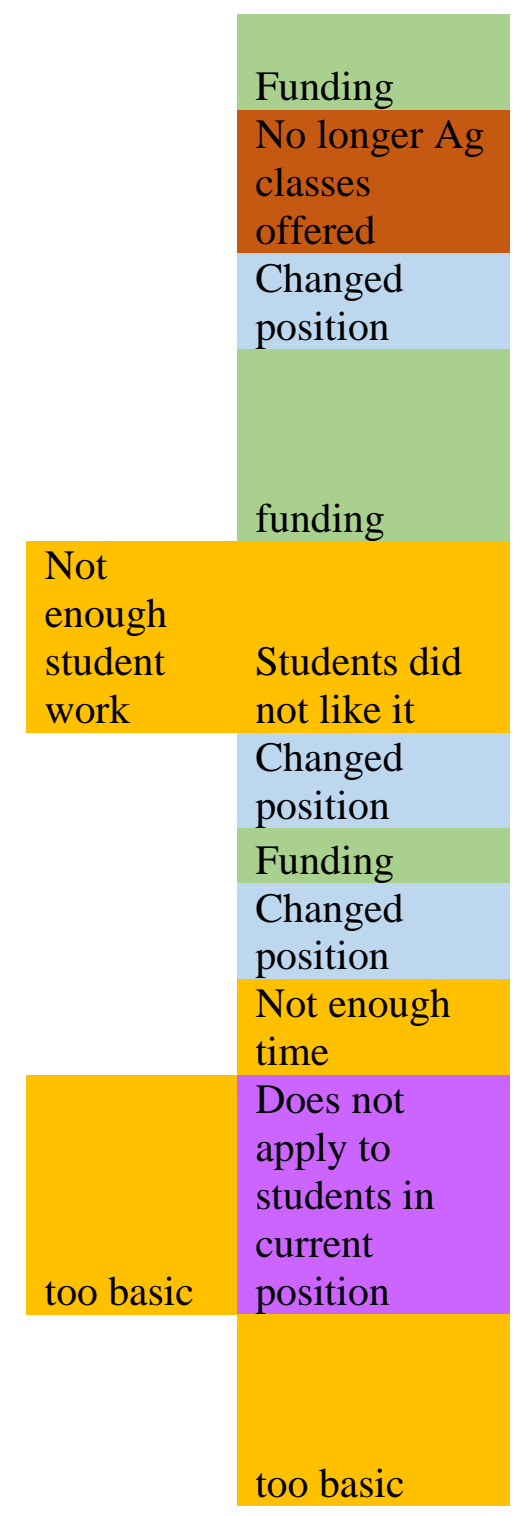

My district has not been able to purchase the needed equipment. I use what I can, but without supplies, it's tough to do most of it.

My principal instituted a BioMedical science class that all freshmen have to take. There is no choice between the two classes.

My schedule was filled with different science classes :(

My school would not purchase all the needed equipment, and without the equipment you really can't do the lessons. It's good curriculum if you have ALL the money to make it work. I also think that once you have been through one training you should not have to go through another full week for another course.

My students weren't a big fan of most of the worksheets and I found that it didn't keep them busy enough and didn't give them all the information they needed to know. I do like the activities using the Lab Quests however.

My teaching assignment changed. Another teacher teaches the CASE classes at my school. not enough \$ from school to implement

not scheduled with that class

So much already to do

The CASE curriculum does not offer high level questioning and is very bland. The labs and projects are extremely long, but do not really require much thinking or analyzing of data.

The course content is very basic- too basic- science principles and theories- mostly at a middle school level. Ag Ed is the practical application of these theories which CASE is weak in. CASE is too much theory, very little application. Most of the CASE curriculum is already being taught in middle school science classes in my state. 


\begin{tabular}{|l|l|} 
& funding \\
\hline too much & \\
science/ & \\
too & \\
complicat & \\
ed & funding \\
& too \\
& complicated \\
& Funding \\
\hline
\end{tabular}

The course was not offered when I began this job. I will need to find outside funding for much of the equipment needed. I hope to teach it within 2-3 years

The curriculum was too science based and I was repeating many of the same labs as the science teachers. Also the materials are incredibly expensive.

Too complicated getting set up.

unavailable funds and resources 


\section{VITAE}

Education:

West Virginia University, Morgantown, WV 26506.

Bachelor of Science in Agriculture with a major in Agricultural and Extension Education. Course work specializing in: animal science, plant and soil science, greenhouse management, biology, leadership, and communications.

Date of graduation: May, 2014.

Overall GPA: 3.8/4.0

- Selected as Outstanding Senior in the division of Resource Management in the Davis College of Agriculture, Natural Resource and Design.

- Selected as a top 36 senior in the 2014 graduating class a West Virginia University.

- Recipient of the Richard Russell undergraduate Service and Leadership Award.

- Certified in teaching Agricultural Education/ Earth Sciences in grades 5-12. 